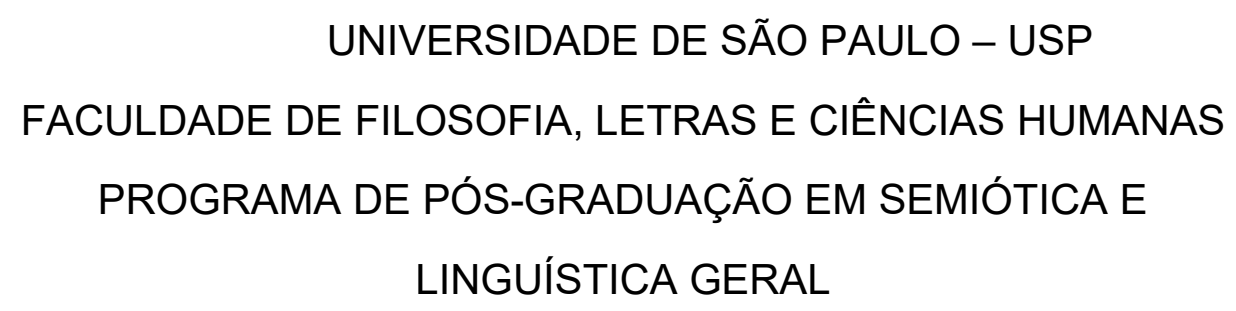

TATIANA CRISTINA CARLOTTI

Poéticas da liberdade: experimentalismo e significação no romance contemporâneo brasileiro

\author{
Versão Corrigida
}

São Paulo 
TATIANA CRISTINA CARLOTTI

\title{
Poéticas da liberdade: experimentalismo e significação no romance contemporâneo brasileiro
}

\author{
Versão Corrigida
}

Tese apresentada ao Programa de Pós-Graduação de Semiótica e Linguística geral do Departamento de Linguística da Faculdade de Filosofia, Letras e Ciências Humanas da Universidade de São Paulo para obtenção do título de Doutora em Linguística.

Área de concentração: Semiótica e Linguística Geral

Orientador: Prof. Dr. Antonio Vicente Seraphim Pietroforte

\section{São Paulo}


Autorizo a reprodução e divulgação total ou parcial deste trabalho, por qualquer meio convencional ou eletrônico, para fins de estudo e pesquisa, desde que citada a fonte.

\section{Catalogação na Publicação}

Serviço de Biblioteca e Documentação

Faculdade de Filosofia, Letras e Ciências Humanas da Universidade de São Paulo

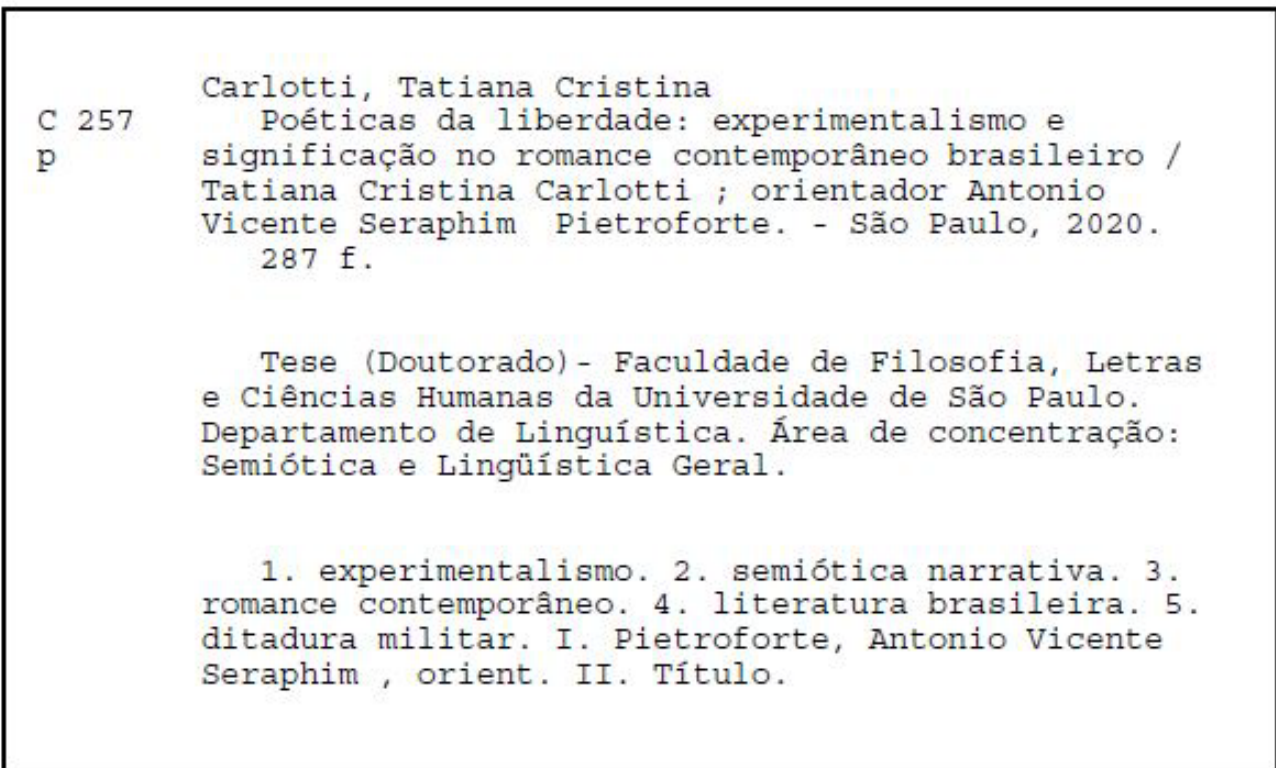




\section{ENTREGA DO EXEMPLAR CORRIGIDO DA DISSERTAÇÃO/TESE}

\section{Termo de Ciência e Concordância do (a) orientador (a)}

Nome do (a) aluno (a): Tatiana Cristina Carlotti

Data da defesa: 22 /02/ 2021

Nome do Prof. (a) orientador (a): Antonio Vicente Seraphim Pietroforte

Nos termos da legislação vigente, declaro ESTAR CIENTE do conteúdo deste EXEMPLAR CORRIGIDO elaborado em atenção às sugestões dos membros da comissão Julgadora na sessão de defesa do trabalho, manifestando-me plenamente favorável ao seu encaminhamento e publicação no Portal Digital de Teses da USP.

São Paulo, 15 /04 /2021

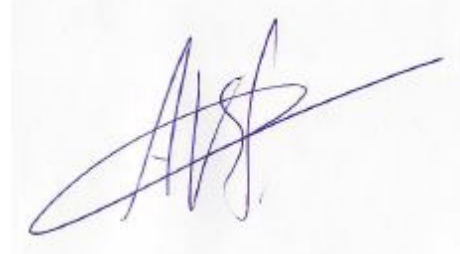

Antonio Vicente Seraphim Pietroforte 
CARLOTTI, Tatiana Cristina. Poéticas da liberdade: experimentalismo e significação no romance contemporâneo brasileiro. Tese apresentada ao Programa de Pós-Graduação de Semiótica e Linguística geral do Departamento de Linguística da Faculdade de Filosofia, Letras e Ciências Humanas da Universidade de São Paulo para obtenção do título de Doutora em Linguística. São Paulo, abril de 2020.

Data do exame: 22 de fevereiro de 2021

Banca Examinadora:

Prof. Dr. Mauricio Salles de Vasconcelos

(FFLCH-USP)

Prof. Dr. Moacir Aparecido Amâncio

(FFLCH-USP)

Prof. Dr. Guilherme Demarchi Silva

(Externo) 
Nome: CARLOTTI, Tatiana Cristina

Título: Poéticas da liberdade: experimentalismo e significação no romance contemporâneo brasileiro

Tese apresentada ao Programa de Pós-Graduação de Semiótica e Linguística geral do Departamento de Linguística da Faculdade de Filosofia, Letras e Ciências Humanas da Universidade de São Paulo para obtenção do título de Doutora em Linguística.

Aprovada em: 22 de fevereiro de 2021

Assinatura do orientador:

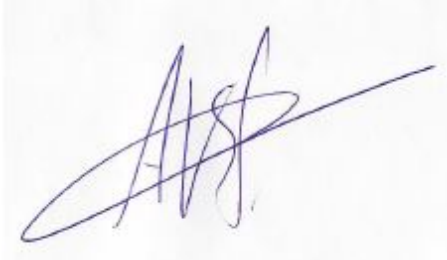

Antonio Vicente Seraphim Pietroforte 


\section{AGRADECIMENTOS}

À Faculdade de Filosofia, Letras e Ciências Humanas pela resistência e salvaguarda do pensamento crítico no Brasil.

Ao Departamento de Linguística da Faculdade de Ciências Humanas da Universidade de São Paulo, pela acolhida generosa e por todas as oportunidades de ampliação dos meus conhecimentos acadêmicos.

À Coordenação de Aperfeiçoamento de Pessoal de Nível Superior (CAPES), pela bolsa concedida para a produção do presente trabalho.

À banca de doutoramento, os professores Moacir Amâncio, Maurício Salles Vasconcellos e Guilherme Demarchi pela leitura e contribuições fundamentais.

Ao Antonio Vicente Pietroforte Seraphim pelas orientações e, em particular, pelas desorientações nestes quatro memoráveis anos de arte \& política.

Aos queridos pesquisadores do GEPOEX, o nosso grupo de Poéticas Experimentais, pela alegria, paciência e carinho.

Aos queridos Ana Carolina Cortez Noronha, Diana Mendes, Sandro Maio e Tirzá Gelbcke Gubert pela leitura paciente deste trabalho.

Aos cúmplices que me estruturam.

Ao Balzac, in memoriam. 


\section{RESUMO}

\section{CARLOTTI, T. C. Poéticas da liberdade: experimentalismo e significação no}

romance contemporâneo brasileiro. 2020. 297f. Tese (Doutorado) Departamento de Linguística da Faculdade de Filosofia, Letras e Ciências Humanas da Universidade de São Paulo, São Paulo, 2020.

No presente trabalho, nós analisamos, a partir da semiótica narrativa e das teorias do discurso, procedimentos experimentais praticados em três romances brasileiros contemporâneos: PanAmérica (1967) de José Agrippino de Paula, Zero (1974/1975) de Ignácio de Loyola Brandão; e Riverão Sussuarana (1978) de Glauber Rocha. Nosso objetivo é apresentar uma tipologia do experimentalismo na prosa contemporânea, propondo uma chave de leitura para essas narrativas, em geral, pouco conhecidas. Para tal, nós optamos por um corpus minimamente homogêneo: são todos romances publicados durante a ditadura militar (1964-1985), e que refletem o contexto de ebulição política e cultural no país e no mundo, articulando temas e figuras inspirados nos embates e personagens (ficcionais ou não) da Guerra Fria. Nós defendemos a hipótese de que o experimentalismo potencializa a crítica desses artistas contra as várias opressões do período, em particular, as tentativas de silenciamento da inteligência crítica nacional durante 21 anos de ditadura. Para estabelecer critérios de análise desses experimentalismos, nós utilizamos como base teórica os trabalhos dos semioticistas A.J.Greimas e Jean-Marie Floch, que nos permitem observar, com rigor e método, como a ilusão da realidade é construída no discurso literário e, em particular, nesses três romances experimentais que nos convidam a uma dupla revolução - a da arte e a da política -, em um contexto impossível de separar essas duas dimensões.

Palavras-chave: experimentalismo, semiótica narrativa, romance contemporâneo, literatura brasileira, ditadura militar 


\section{ABSTRACT}

CARLOTTI, T. C. Poetics of freedom: experimentalism and signification in contemporary Brazilian romance. 2020. 297f. 2020. 297f. Tese (Doutorado) Departamento de Linguística da Faculdade de Filosofia, Letras e Ciências Humanas da Universidade de São Paulo, São Paulo, 2020.

In the present work, we analyze, based on narrative semiotics and discourse theories, experimental procedures practiced in three contemporary Brazilian novels: PanAmérica (1967) by José Agrippino de Paula, Zero (1974) by Ignácio de Loyola Brandão; and Riverão Sussuarana (1978) by Glauber Rocha. Our goal is to present a typology of experimentalism in contemporary prose, proposing a key for reading these narratives, in general, little known. For this, we opted for a minimally homogeneous corpus - they are all novels published during the military dictatorship (1964-1985), which reflect the context of political and cultural boiling, in the country and in the world, articulating themes and figures inspired by the clashes and characters (fictional or not) of the Cold War - and we defend the hypothesis that experimentalism potentiates criticism and shapes the cry of these artists against the various oppressions and, above all, attempts to silence a critical, artistic, popular and cultural intelligence in Brazil . In order for us to establish criteria among the experimentalisms practiced in these novels, we will use the works of semioticians A.J.Greimas and Jean-Marie Floch as central theoretical references, observing how the illusion of reality is constituted in these three novels that signal a double revolution, aesthetics and politics, in a period when it was impossible to separate these two dimensions.

Keyword: experimentalism, narrative semiotics, contemporary novel, Brazilian literature, military dictatorship 
O que mata na ditadura é que não há espaço para a verdade porque não há espaço para a vida, senador. Porque algumas verdades, até as mais banais, podem conduzir à morte. (Dilma Rousseff, Sessão Senado Federal, 07.05.2008) 


\section{Poéticas da liberdade: experimentalismo e significação no romance contemporâneo brasileiro}

\section{Sumário}

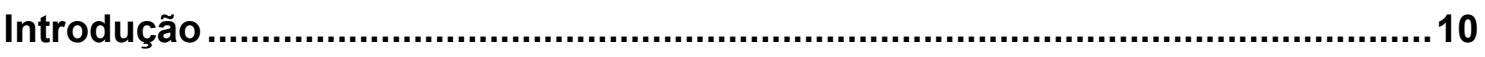

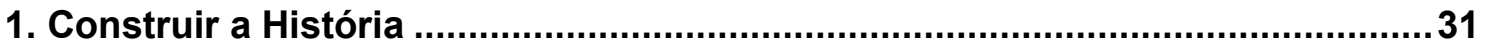

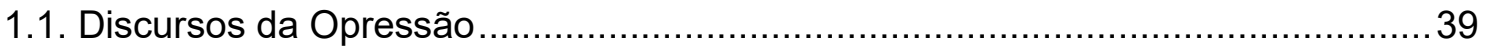

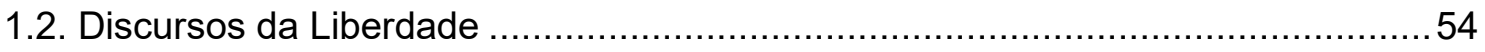

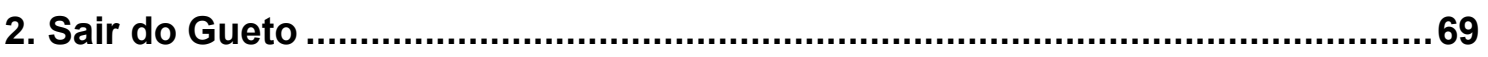

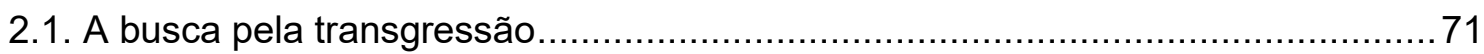

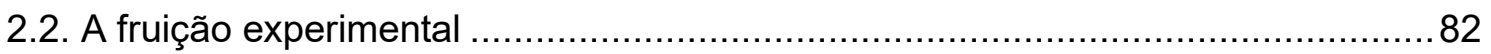

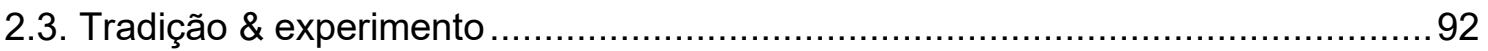

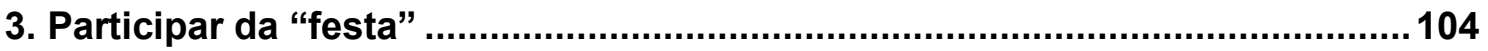

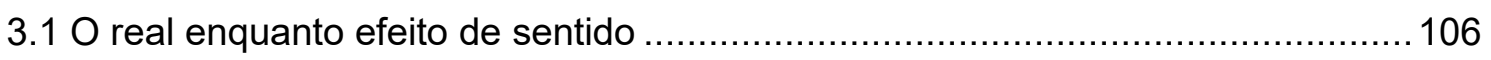

3.2. O regime oblíquo em PanAmérica ......................................................... 122

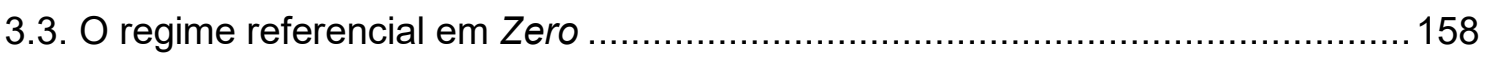

3.4. O regime substancial em Riverão Sussuarana ............................................. 194

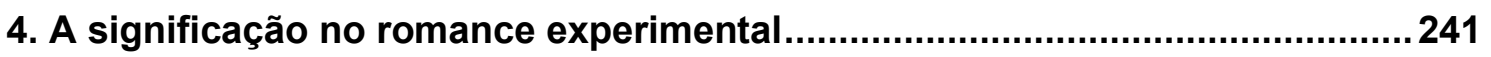

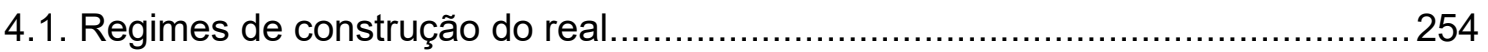

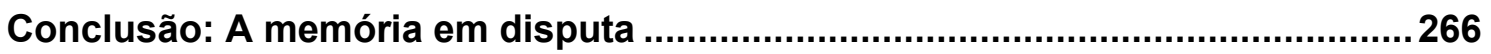

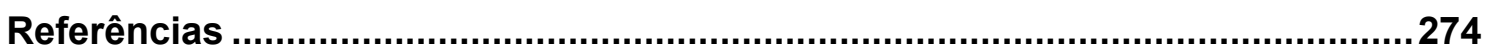




\section{Introdução}

Figura 1 - Suzana Hidalgo, Chile, 25 out. 2019

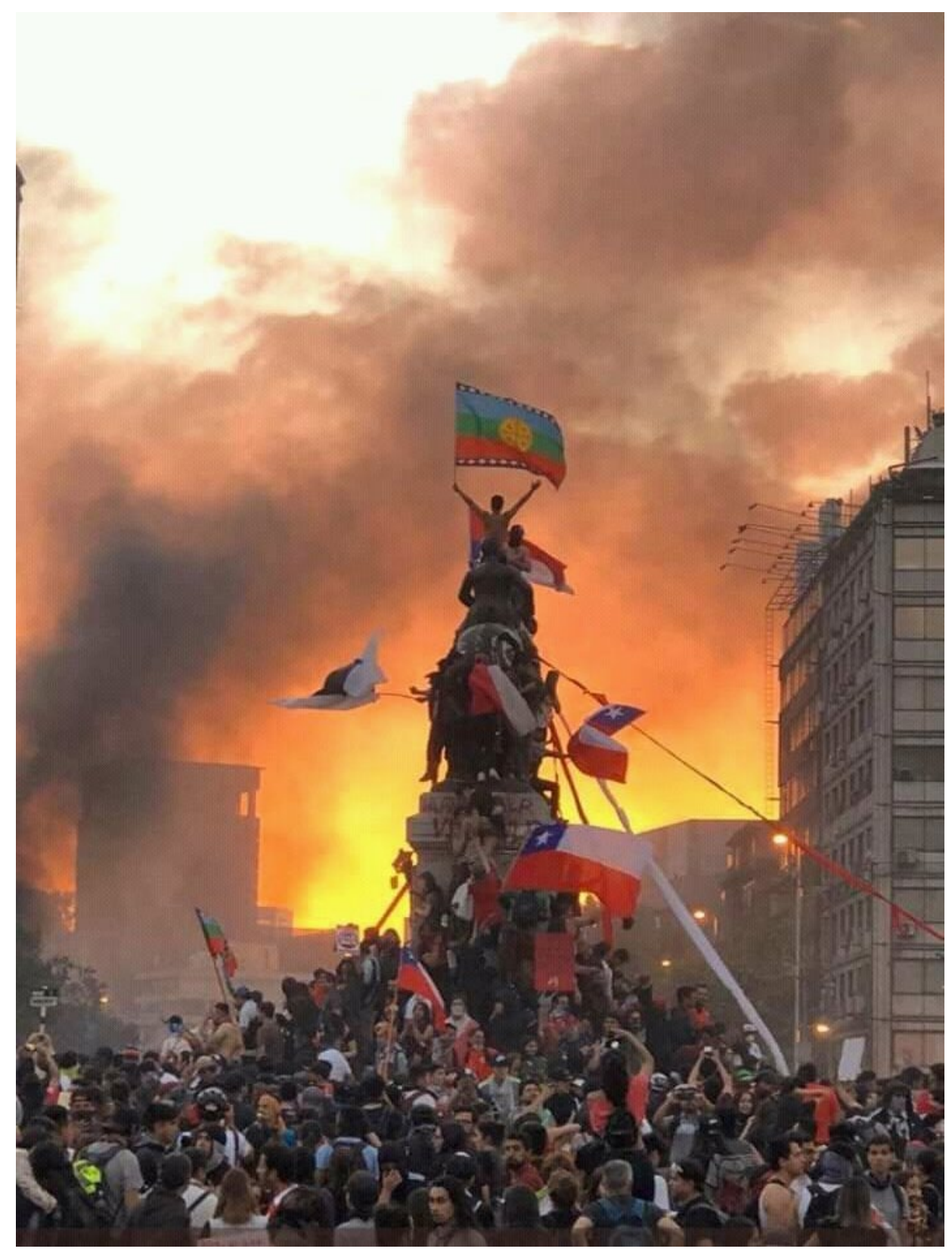

Fonte: BBC News Brasil, 29 out. 2019

A imagem da bandeira mapuche empunhada por um jovem, no alto de uma estátua, tornou-se emblemática das manifestações chilenas em 2019, conferindo cor, temperatura e movimento à utopia da conquista do poder pelo povo. 
Compartilhada nas redes sociais pela atriz chilena Suzana Hidalgo, a fotografia correu pelas veias ainda abertas de uma América Latina que, após a "onda vermelha" dos governos progressistas, durante os anos 2000, viu-se novamente submetida aos planos de austeridade, impostos por governos alinhados a forças econômicas que exigiam a desresponsabilização social do poder público, conforme denunciavam os chilenos - 1,2 milhão apenas em Santiago -, naquele memorável 25 de outubro ${ }^{1}$ de 2019.

Dias depois, preocupado com a possibilidade de contágio dos protestos no Brasil, o então deputado Eduardo Bolsonaro (PSL-RJ), líder do governo na Câmara e filho do presidente da República, em entrevista à jornalista Leda Nagle, afirmava:

Se a esquerda radicalizar a este ponto, a gente vai precisar ter uma resposta, e uma resposta pode ser via um novo Al-5; pode ser via uma legislação aprovada através de plebiscito como ocorreu na Itália, alguma resposta terá de ser dada". (Bolsonaro, 31.10. 2019)

Declaração contundente que expressa o quanto o discurso sobre a ditadura militar (1964-1985) se encontra em disputa na sociedade brasileira, apesar de passados mais de cinquenta anos do golpe. E, também, como a ditadura pode ser euforizada a partir do que nela houve de pior: o Al-5, inserido acima como plausível e até necessário, "em resposta" (o termo é repetido três vezes) à radicalização da esquerda, de antemão culpabilizada, conforme a habilidade dos discursos violentos em transferir a responsabilidade do agressor à vítima.

A declaração é agravada frente ao completo desconhecimento do termo "Al-5" por grande parte da população brasileira, precisamente $65 \%$ dos brasileiros segundo cálculos da pesquisa Datafolha (FSP, 01.01.2020). Um imenso contingente de indivíduos expostos à proposta de endurecimento do regime, diante de um termo que não compreendem, e que é naturalizado na

$1 \mathrm{Um}$ ano depois, em 25 de outubro de 2020, o povo chileno decidia, em plebiscito histórico, derrubar a Constituição vigente desde a época da ditadura de Augusto Pinochet (1973-1990); e convocar Assembleia Constituinte para construir um novo pacto constitucional no país (FSP, 25.10. 2020). 
entrevista pela ausência do contraditório, assim que a proposta foi feita; e pela equivalência absurda entre dois termos - Al-5 e plebiscito -, embora ambos pertençam a campos discursivos antagônicos: Al-5 relacionado à opressão, eliminação de desafetos, voz única, instrumento por excelência do exercício do poder pelos ditadores; plebiscito relacionado à liberdade, democracia direta, pluralidade de vozes, instrumento por excelência do exercício do poder pelo povo. Aproximados na oração como se equivalentes fossem, o "Al-5" é apresentado à maioria que não sabe seu impacto na vida política, econômica, intelectual e cultural do país, como "opção" viável "aos ataques" da esquerda (radicalização). Ao mesmo tempo, aos 35\% que compreendem o termo, é reiterada a ameaça de um novo Al-5.

Em nenhum momento da entrevista, o telespectador, ou melhor, o enunciatário (a quem se dirige o discurso enunciado) é informado que, entre 1968 e 1978, o Ato Institucional n. 5 permitiu a três ditadores - Costa e Silva (1967-69), Emílio Médici (1969-74) e Ernesto Geisel (1974-79) - eliminar adversários e desafetos, seus e dos financiadores de seus governos. Prática executada na cassação de mandatos parlamentares e de postos da administração pública, fechamento do Congresso Nacional, intervenção direta no exercício de vários entes federativos, supressão de habeas-corpus de opositores, desafetos ou pensadores críticos ao regime, acompanhado de prisão, tortura, assassinato e desaparecimento de corpos, conforme nos permite saber (e dizer) todo o conhecimento acumulado e divulgado, ao longo de mais de três décadas de redemocratização, por vítimas do Estado militar e por uma série de pesquisadores deste então.

Um consolidado de testemunhos e autobiografias, evidências materiais, inclusive ossadas identificadas, documentos os mais variados, pesquisas acadêmicas, investigações jornalísticas, bibliografia especializada, obras das mais diferentes linguagens artísticas; e, desde 2014, o calhamaço com mais de seis mil páginas elaborado pela Comissão Nacional da Verdade (CNV), que investigou os crimes de lesa humanidade considerados imprescritíveis pelas Nações Unidas.

Apesar disso, 57.796.986 brasileiros elegeram para a presidência da República em 2018, um político que criou sua marca reavivando slogans da 
ditadura militar, a partir de uma retórica violenta contra a esquerda; e bastante atrativa aos saudosistas da ditadura; às milícias, organizações paramilitares herdeiras dos grupos de extermínio de outrora2; e aos que comungam com a visão de mundo de uma direita performaticamente agressiva, que se manifesta a partir de um discurso eufórico em relação à ditadura. Ressuscitando querelas e táticas de outrora, como a criação do inimigo interno, em espécie de simulacro da Guerra Fria, passados mais de cinquenta anos daqueles episódios.

A crescente (e permanente) ameaça de revisionismo histórico da ditadura militar, como pontuaremos em vários momentos deste trabalho, foi central para a definição do corpus. Nosso propósito aqui é apresentar uma tipologia do experimentalismo praticado no romance brasileiro contemporâneo, a partir da análise de três obras publicadas no Brasil, em meio à ebulição cultural, política, social e comportamental dos anos 1960 e 1970.

Com isso, gostaríamos de contribuir com (1) o repertório deste arquivo coletivo, persistente e vigilante, da memória sobre a ditadura militar brasileira, a última experiência com o autoritarismo de Estado que sofremos enquanto Nação; e, também, contribuir (2) com o debate sobre as práticas experimentais na linguagem verbal e poética, a partir de três textos magistrais, escritos por três artistas que participaram ativamente da revolução política e cultural de seu tempo.

E que tempos...

\section{Por que essas obras?}

Em A literatura como arquivo da ditadura brasileira (2017), Eurídice Figueiredo (Estudos de Literatura - UFF) apresenta uma sistematização das narrativas escritas "sobre os desmandos da ditadura", analisando-as enquanto "arquivo" da ditadura, na medida em que elas permitem "o inventário das feridas

2 Em A República das milícias: dos esquadrões da morte à era Bolsonaro (2020), o jornalista Bruno Paes Manso conta, por meio de uma série de entrevistas, a história das milícias no Brasil. (Manso, 2020). 
e das cicatrizes que as torturas e as mortes provocaram em milhares de brasileiros", com a diferença de que "os arquivos, em sentido estrito, são documentos de leitura árida, reservados aos historiadores, enquanto a literatura atinge um público amplo" (Figueiredo, 2017, p.47).

Ela organiza esse acervo em três momentos: de 1964 a 1979, com produção marcada pela tônica "ora prospectiva e utópica, ora distópica diante do fracasso dos projetos revolucionários"; de 1980 a 2000, com predominância do relato autobiográfico de ex-presos políticos que retornavam ao país, beneficiados pela Lei de Anistia, promulgada em 1979; e a partir do ano 2000, com narrativas de caráter mais "retrospectivo", em que se percebe "maior depuração mesmo ao tratar o trauma dos desaparecidos" (Idem, p.47-8).

O corpus do presente trabalho abrange, justamente, esse primeiro momento da produção literária sob e sobre a ditadura militar.

Ele é composto por três romances:

- $\quad$ PanAmérica de José Agrippino de Paula, publicado em 1967. Sua escolha se deve ao experimentalismo do texto, à sua importância para a Tropicália; e à epopéia pop que o autor constrói a partir do universo hollywoodiano e de episódios políticos e culturais no contexto da Guerra Fria;

- Zero de Ignácio de Loyola Brandão, publicado primeiramente em 1974 na Itália, por medo da repressão; e em 1975 no Brasil, onde acabou censurada até 1979. Sua escolha se deve ao impacto da obra naquele período, e à denúncia visceral contra o regime militar que traz, a partir da perspectiva de um trabalhador, sem vantagem alguma, na periferia do capitalismo;

- $\quad$ Riverão Sussuarana de Glauber Rocha, publicado em 1978. Sua escolha deve-se ao fato de a obra ser o registro da escritura de Glauber na linguagem verbal, pelo diálogo contínuo que ela estabelece com a tradição e os personagens da mítica sertaneja, em particular, com Guimarães Rosa.

Discursos poéticos, em distintos momentos e temperaturas da repressão política, essas obras conseguiram condensar nos planos de conteúdo e de expressão as contestações de sua contemporaneidade, transformando-se em contundentes afirmações das liberdades individuais e coletivas, em particular, da 
liberdade de expressão. Elas nos permitem igualmente contribuir com o repertório sobre a ditadura militar, na medida em que foram publicados em três momentos distintos da ditadura, abrangendo as tensões do começo, meio e fim de uma experiência coletiva do autoritarismo de Estado; e construir uma tipologia do experimentalismo praticado na literatura contemporânea brasileira.

Nós partimos da hipótese de que o experimentalismo adotado por esses romances dialoga com os silenciamentos (interditos e não ditos) daquele período, na medida em que as três narrativas constituem verdadeiras avalanches polifônicas, capazes de abranger, por conta de suas arquiteturas não convencionais, tanto os discursos de poder (encráticos) quanto os de contrapoder (acráticos) e assim oferecê-los ao leitor. A adoção da experimentação enquanto estratégia discursiva faz dessas narrativas particularmente combativas, contrariamente à redução promovida tanto pelo senso comum, quanto por setores da crítica especializada, que classificam literaturas experimentais ora como "obras esquerdistas", ora como "obras alienadas".

Permeadas pelas opressões e liberdades que se insurgiram naquele momento, essas obras são dotadas de grande inventividade e potência expressiva. Apresentando-se como composições de fragmentos (unidades cênicas), elas irão articular temas e figuras de sua contemporaneidade, trabalhando os principais discursos que circularam na seara política e cultural, entre meados de 1950 e fins de 1970, ou seja, em plena Guerra Fria, não menos bélica na América Latíndia de Loyola Brandão, na PanAmérica de José Agrippino de Paula, e no sertão de Glauber Rocha.

Territórios de livre-expressão, essas obras tematizam a fratura da ordem democrática, o dilaceramento dos corpos (e dos sonhos), as mazelas do subdesenvolvimento, o autoritarismo tacanho, a asfixia dos mais plurais desejos; ao mesmo tempo, elas trazem o sonho e a luta, a teoria e a práxis revolucionárias, a crítica e a ruptura de amarras morais, comportamentais, sexuais e estéticas de uma geração que, sacudida pelos ventos da História, acreditou na própria capacidade de mudar a realidade, em um dos mais transformadores contextos da nossa contemporaneidade, quando foram 
hasteadas bandeiras civilizatórias que, meio século depois, ainda penamos (e como) para implementar.

\section{Por que narrativas experimentais?}

Além de situadas no contexto de sua contemporaneidade, essas narrativas nos permitem discutir e observar a prática experimental, em seu caráter artesanal e dialógico. Assim que instauradas no discurso, elas evocam, pelo estranhamento que promovem, o texto tradicional; enunciando permanentemente o hiato entre convenção e experimentação, na medida em que efeitos de sentido das narrativas tradicionais, assim que suprimidos ou saturados, são imediatamente identificados. Neste sentido, elas demandam outra performance de leitura, transformando-nos em co-enunciadores, afinal, diante dessas obras, somos constantemente levados a preencher as lacunas de sentido decorrentes de sucessivas e variadas descontinuidades, por exemplo, a ruptura da linearidade.

Nossa escolha também se deve ao fato de as narrativas experimentais serem constantes no cânone literário brasileiro, por exemplo, Serafim Ponte Grande (1933) de Oswald de Andrade, que combina diferentes gêneros discursivos, rompendo a linearidade; Grande Sertão: Veredas (1956) de Guimarães Rosa, que subverte o código verbal; e tantas outras. Longe de serem exceção, os procedimentos experimentais são definidores do nosso cânone, e atuam na ampliação das possiblidades de expressão da linguagem poética, e na definição daquilo que compreendemos por literatura brasileira.

Apesar disso, depois dos anos 1970, as narrativas experimentais caíram em descrédito. Tânia Pellegrini (Teoria Literária - UFSCAR) nos ajuda a compreender esse fenômeno no artigo "Relíquias da Casa Velha: literatura e ditadura militar, 50 anos de depois" (2014), em que trabalha os rumos da literatura durante e após a ditadura militar. Ela destaca a incidência de duas censuras na produção cultural do período: a repressão militar propriamente dita que, além de impedir a publicação e circulação das obras, perseguiu e exiliou considerável parte da inteligência política, cultural e artística nacional, em 
particular depois do Al-5; e a censura do mercado, instituída no país sob beneplácito dos militares, que levou à adequação da arte nacional aos valores e às fórmulas da indústria cultural, predominantemente norte-americana.

Segundo Pellegrini,

O resultado da política sistemática do regime para a área da cultura foi a definitiva impressão do selo do mercado na criação, substituindo o ritmo lento de décadas anteriores, ainda com muito de precário e artesanal, por uma grande pressa produtiva, no atendimento e formação de públicos potenciais. Pode-se afirmar que, desde então, o mercado passou a ser definitivamente um elemento constitutivo da produção cultural, exercendo uma profunda influência, de fora do âmbito artístico, entranhando-se nas configurações de conteúdo e forma (Pellegrini, 2014, p.163).

Especificamente sobre a Literatura, Pellegrini pondera que, durante o período militar, houve considerável aumento das publicações, beneficiadas por políticas de incentivo como, por exemplo, a criação da Embralivro, mas essa modernização foi seletiva. De forma geral, os autores nacionais tiveram de "encaixar sua produção nesses novos parâmetros" da indústria cultural para "competir em um mercado inflado por produtos estrangeiros (cresceu muito o número de best-sellers traduzidos)", tornando-se "adequados ao gosto do novo público, já formado basicamente pela TV" (ibidem).

Essa adequação é explicitada por Sandra Reimão, em Mercado Editorial Brasileiro (2018), uma análise sobre o mercado do livro ao longo das décadas 1960, 1970 e 1980. Ela conta que, em 1960, houve um período de explosão qualitativa das obras editadas no país, no entanto, a tiragem de livros e número de habitantes não ultrapassava 1 livro por habitante, permanecendo entre 0,5 (1960) e 0,7 (1969) ao longo da década:

Essa "explosão" foi uma explosão qualitativa que se deu num reforço mútuo entre o público leitor e editores. Leitores que dispunham, nos gêneros públicos, de obras polêmicas e de fôlego (elaboradas por produtores culturais de formação literária) e que buscavam nos livros a mesma qualidade e relevância. $E$ produtores editoriais, que, para acompanhar esse público e 
vender seus livros, tinham que se aprimorar qualitativamente cada vez mais. Esse processo parece também ter sido represado em 1968. (Reimão, 2018, p. 25)

A virada ocorre em 1972, quando atingimos 1,3 livro editado por habitante, chegando a 1,9, em 1979. Com essa expansão, Reimão observa a segmentação do conteúdo publicado no país:

Em meados dos anos 70 , a convivência de produções culturais bastante díspares: textos atrelados ao star system televisivo, romances políticos, literatura nacional formalmente inventiva e de difícil fruição, literatura de massa e de gosto médio de autores nacionais consagrados, tudo isso ao lado de narrativas de massa de autores norte-americanos ao boom do "realismo fantástico" latino-americano. Essa coabitação disparatada deuse porque o crescimento do mercado e sua solidificação conduziram a sua maior segmentação (ibidem, p. 36 , grifos nossos)

É justamente essa "literatura nacional formalmente inventiva e de difícil fruição" que será expulsa das listas a partir dos anos 1980, quando a padronização se revela:

Dos cem títulos que constam das listas anuais de livros de ficção mais vendidos no Brasil entre 1980 e 1989, 74 são de autores estrangeiros (...) Enfocando o segmento ficção nos anos 80 no Brasil, pode-se dizer que o protótipo de livro mais vendido foi o romance de autor estrangeiro, de confecção literária média, sem subgênero definido (...) Dos cem títulos [de não ficção] que compõem as dez listas anuais dos dez títulos mais vendidos, 55 são de autoria de escritores brasileiros, sendo que os "picos" dessa presença se deram nos anos de 1984 e 1986 (ibidem, p. 48-49).

Fenômeno que se espraia em praticamente todos os âmbitos de expressão artística, conforme destaca Antônio Vicente Seraphim Pietroforte (Linguística/Literatura Comparada - USP) ao $\operatorname{citar}^{3}$ a padronização do timbre dos instrumentos musicais pelas grandes gravadoras, interrompendo ou deslocando

3 Citação durante o curso Tópicos de Semiótica Aplicada, realizado no segundo semestre de 2017, pelo programa de pós-graduação em Linguística, da Universidade de São Paulo. 
uma produção inventiva e genuinamente experimental para os circuitos marginais.

Sem desconsiderar as ponderações do filósofo Edgard Morin que, embora crítico à promoção da "qualidade média" pela indústria cultural, salientava o caráter democrático (em termos de acesso) da cultura de massas - "não houve Idade de Ouro da cultura antes da cultura industrial e esta não anuncia a Idade de Ouro", afirmava (1997:52) -, é inegável o impacto do mercado na produção e disseminação do objeto cultural.

Veículos de difusão da cultura como o rádio e a televisão foram fundamentais à democratização do acesso, porém, o enquadramento ideológico da ditadura militar, e a instrumentalização mercadológica do bem cultural - as duas censuras salientadas por Pellegrini - criaram atmosfera completamente desfavorável a produções de cunho experimental, como são as obras do presente corpus.

Quando observamos as listas dos títulos de ficção mais vendidos pelas principais editoras do país, disponibilizada pelo site Publishnews, observamos que, entre 2010 e 2020, ao longo de uma década, as narrativas experimentais sequer entraram nessas listas. Entre os dez mais vendidos, ano após ano, o número de títulos nacionais não ultrapassa o de títulos internacionais, com predomínio das traduções, em geral best sellers ou obras adaptadas para o cinema.

Soma-se a isso os trágicos índices de leitura no país, como revela a última edição da pesquisa Retratos da Leitura no Brasil (2020) do Instituto Pró-Livro e Itaú Cultural. O gráfico abaixo nos permite observar o percentual de leitores e não leitores entre 2007 e 2019: 
Figura 2: Leitor - Percentual e Estimativa populacional

\section{Estimativa}

\section{Milhões Leitor Não Leitor}

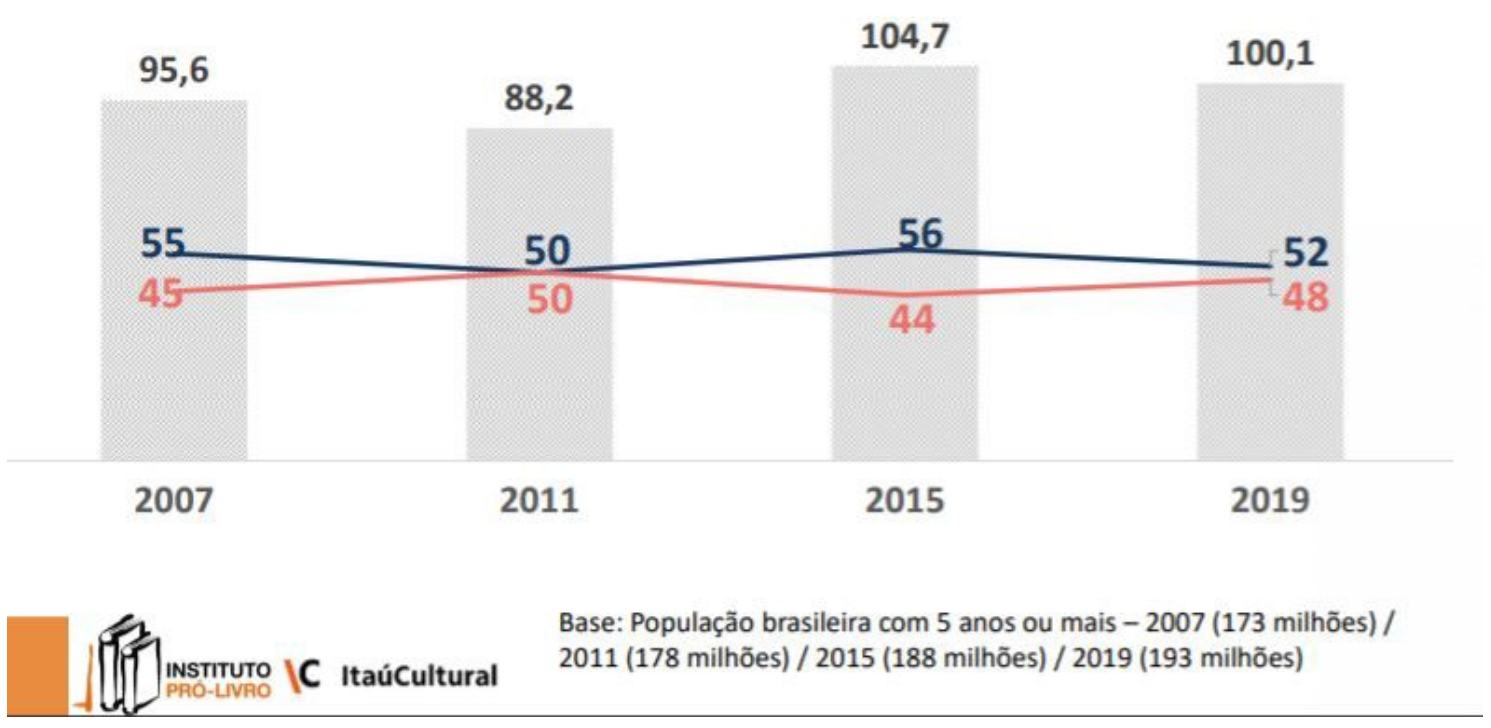

Fonte: Retratos da Leitura no Brasil, 2020

Entre 2015 e 2019, um intervalo de apenas quatro anos, o Brasil perdeu 4,6 milhões de leitores. Em 2015, éramos 56\% da população; em 2017, somos $52 \%$ ante um universo de $48 \%$ de não leitores (que significa não ter lido nada nos últimos três meses). Em meio ao refluxo e à ingerência do mercado, o espaço nas gôndolas das livrarias é preenchido por uma literatura essencialmente convencional. E por mais que se tente driblar a padronização, ela incide sobre a invenção. Editores ou colegiados, responsáveis pela definição do que será ou não publicado, optam pelo minimamente vendável. E, neste sentido, é de imensa importância a emergência das pequenas editoras, cooperativas de escritores e publicações próprias neste começo de década. É o que traz esperanças.

O contrapeso ao desinteresse do mercado pelas narrativas experimentais seria, obviamente, a pesquisa acadêmica, caso não houvesse essa espécie de "Cabo das Tormentas" capaz de naufragar o interesse dos pesquisadores sobre a literatura dos últimos cinquenta anos no país. Apenas a título de exemplo, a biblioteca digital de Teses e Dissertações da Universidade de São Paulo 
registra ${ }^{4}$ entre dissertações, teses e livre-docências referentes aos nossos autores ou que os nomeiam em seus resumos apenas 15 pesquisas sobre Glauber Rocha; seis sobre José Agrippino de Paula; e dois sobre Loyola Brandão, em 2019, tornado “imortal” pela Academia Brasileira de Letras.

A ausência de crítica sobre obras experimentais deixa possíveis apreciadores dessas narrativas totalmente desamparados. Daí a urgência de conteúdo crítico, se não capaz de auxiliá-los na fruição dessas obras, pelo menos de convocá-los a se aventurarem pelas sucessivas desestabilizações promovidas por essas experimentações. Algo totalmente plausível como ensina a sólida crítica literária dos experimentalismos praticados por Clarice Lispector que conta com inúmeras pesquisas acadêmicas, e livre trânsito na mídia cultural, evidenciando a plena possibilidade de uma relação produtiva, educativa e lucrativa entre mercado e arte no campo literário.

Enquanto isso não ocorre, a narrativa experimental brasileira vive um interessante paradoxo: é considerada "inventiva" ou "original" quando cânone; mas "complicada", "mal-acabada", "impublicável" e até mesmo "inexistente" nos dias de hoje, sem falar dos que ainda a taxam de "alienada" ou "alienante".

\section{Escolhas metodológicas}

Ao vislumbrarmos a possibilidade de elaborar uma tipologia do experimentalismo, não tivemos dúvidas quanto ao rigor metodológico e a pertinência da semiótica narrativa e das teorias do discurso para a sua construção. Será a partir dessas categorias que iremos estabelecer uma tipologia dos experimentalismos praticados no romance brasileiro contemporâneo, analisando e sistematizando narrativas que utilizaram a

4 A Biblioteca Digital de Teses e Dissertações da USP pode ser acessada em < https://teses.usp.br/ >, clicando em pesquisa avançada (coluna à esquerda) 
experimentação como instrumento de denúncia e de reelaboração do real, naquele contexto de autoritarismo.

Para estabelecermos uma tipologia dos experimentalismos no romance contemporâneo nós iremos analisar (1) as correlações entre os planos de expressão e de conteúdo, observando como os efeitos de realidade são construídos em cada uma dessas obras; e (2) como esses regimes dialogam entre si e com seu contexto histórico, estabelecendo uma chave de leitura para essas e outras narrativas experimentais.

Uma das premissas nas Ciências Humanas é a necessidade de as escolhas metodológicas se guiarem pela especificidade de seus objetos, sem reduzi-los a simples validações de modelos previamente adotados. Neste sentido, a escolha da semiótica narrativa e das teorias do discurso diz respeito ao rigor e à abrangência desses modelos analíticos, capazes de englobar as estruturas profundas (subjacentes ao enunciado e não observáveis) e as de superfície (observáveis), dotando-nos de instrumental sólido para a análise e sistematização de discursos fortemente heterogêneos como os poéticosexperimentais.

Alguns conceitos da semiótica narrativa e das teorias do discurso irão organizar a nossa análise, em particular, o quadrado semiótico e o percurso gerativo do sentido desenvolvidos por A. J. Greimas; a semântica global do linguista Dominique Maingueneau (Universidade de Paris IV Paris-Sorbonne); e as ideologias de construção da realidade propostos pelo linguista Jean MarieFloch (1947-2001). Detalharemos melhor esses conceitos nos capítulos 3 e 4, ao analisarmos cada uma das obras, segue abaixo a apresentação de suas linhas gerais:

\section{- Percurso gerativo do sentido}

Em Semiótica Poética, A. J. Greimas define o discurso poético, objeto de estudo da semiótica poética, como "co-extensivo ao conceito de literatura", afinal a poesia existe "indiferentemente à linguagem em que se manifesta" (Greimas, 
1975, p. 11). O discurso poético é, também, um discurso duplo porque projeta suas articulações simultaneamente nos planos da expressão e do conteúdo. Cabe à semiótica poética, portanto, estabelecer "uma tipologia das correlações entre esses dois planos", investigando a "organização discursiva autônoma" do objeto poético, que não se constitui em "descrição exaustiva do signo", mas sim em uma "operação da construção do objeto, que emerge e adquire forma a partir do estado de coisa em que é oferecido aos nossos sentidos" (ibidem, p.16).

Desenvolvido por Greimas em Du Sens I (1970) e Du Sens II (1983); Semântica Estrutural (1973); Semiótica das Paixões (1993) e em outros trabalhos de fôlego, o percurso gerativo do sentido, como o próprio nome revela, é um modelo teórico que nos permite observar como o sentido é construído em camadas, ou melhor, a partir de níveis que irão constituir o plano de conteúdo de qualquer discurso. Nas palavras de Greimas e Fontanille, trata-se do "escoamento coagulante do sentido" que parte de uma "imprecisão original e potencial" em direção a "manifestações discursivas propriamente ditas" (1993, p. 12). Em suma: é quando o verbo se torna corpo, e a ideia vira realidade discursiva.

A semiótica narrativa (ou greimasiana) nos ensina a observar a construção desse sentido em três níveis, e em cada um deles ocorre uma complexificação do discurso. O mais abstrato é o nível fundamental. Nele, reside aquela "imprecisão original e potencial", manifesta a partir de índices fóricos, euforia ou disforia, reverberados nas oposições semânticas estruturantes do discurso, por exemplo, a tensão liberdade vs. opressão.

No nível intermediário, chamado de nível narrativo, aquela "imprecisão" (eufórica ou disfórica) original se organiza em torno dos chamados actantes, que irão estabelecer relações uns com os outros: eles podem ser actantes da enunciação (narrador, enunciador, interlocutor/ narratário, enunciatário, interlocutário); ou actantes de enunciado (sujeito, antissujeito, destinador, objeto de valor). O programa narrativo diz respeito à relação entre dois actantes principais: o "sujeito" e o "objeto de valor" que podem estabelecer relações de disjunção ou de conjunção. No primeiro caso, o sujeito busca esse objeto, manipulado por um destinador via sedução, tentação, intimidação ou 
provocação. No segundo, quando ocorre a conjunção, sujeito e objeto se encontram.

Diante da ausência de um objeto de valor, depois de manipulado por algum destinador (outra personagem, algum acontecimento etc.), o sujeito precisará adquirir competências para a realização da performance que o fará entrar ou não em conjunção com o objeto. É quando se dá a sanção que pode ser positiva ou negativa. Em geral, a sanção é realizada pelo destinador que moveu esse sujeito à ação narrativa. O esquema narrativo do percurso gerativo do sentido prevê tanto o percurso de base (o principal, percorrido pelo sujeito em direção ao objeto e valor; quanto os percursos de uso (os secundários, percorridos pelo sujeito durante a etapa de aquisição de competências).

Por fim, no nível discursivo, o mais superficial e complexo nível do percurso gerativo do sentido, ocorre o processo de discursivização, quando a "imprecisão original" ganha corpo, ou seja, torna-se tema e figura; e a voz enunciativa instaura os valores de pessoa (eu/tu - ele), tempo (ontem, agora) e espaço (aqui/acolá). É neste nível que as figuras "dão corpo" aos actantes narrativos do enunciado e da enunciação no processo de figurativização, central para a Literatura.

Como explica o linguista Denis Bertrand (Université Paris VIII),

Essa dimensão figurativa da significação, a mais superficial e rica, a do imediato acesso ao sentido, é tecida no texto por isotopias semânticas, e recobre com toda sua variedade cintilante de imagens as outras dimensões, mais abstratas e profundas. Ela dá ao leitor, assim como ao espectador de um quadro ou de um filme, o mundo a ver, a sentir, a experimentar. A práxis cultural que se sedimenta como uso, fixa então a ordem de "verdade", totalmente relativa, do figurativo em poéticas particulares e convencionais: é, por exemplo, o alegorismo, o realismo, o simbolismo, o surrealismo etc. (Bertrand, 2003, p.29).

Focados na dimensão figurativa da significação, nós iremos apresentar a nossa tipologia, observando como essas obras constroem a sua ilusão de realidade, ou seja, "o mundo a ver, a sentir, a experimentar" nessas obras. 


\section{- Quadrado semiótico}

Como utilizaremos vários quadrados semióticos ao longo do presente trabalho, faz-se necessário demonstrar a lógica interna de sua representação que parte sempre de uma relação de oposição entre dois termos contrários (s1 vs. s2), da qual se desdobram duas outras relações - a de negação e de implicação - como vemos abaixo:

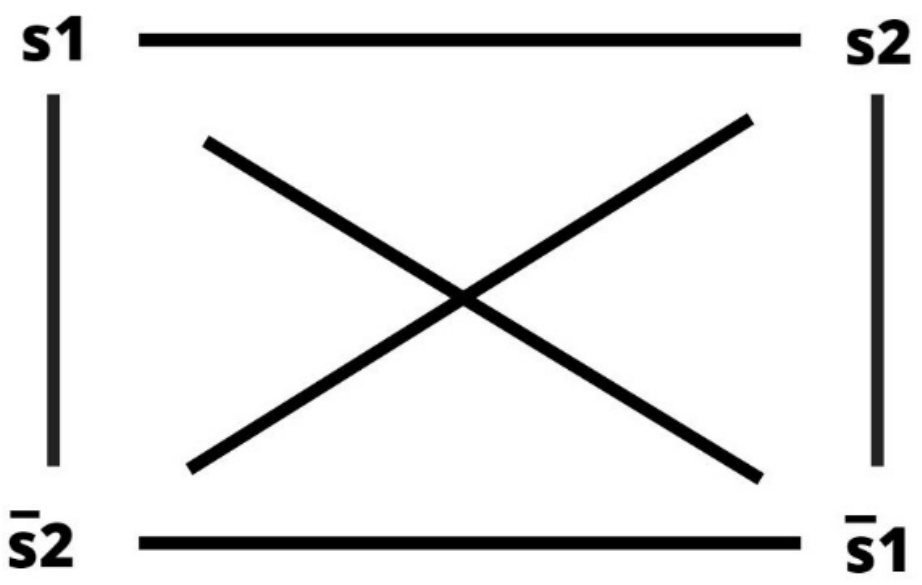

No eixo horizontal, ocorre a relação de oposição entre os termos contrários $\mathrm{s} 1 \mathrm{vs}$. s2, e entre os termos ${ }^{-} \mathrm{s} 2 \mathrm{vs}{ }^{-} \mathrm{s} 1$.

No eixo diagonal, ocorre a relação de negação entre os termos contraditórios $\mathrm{s} 1 \mathrm{e}^{-} \mathrm{s} 1$, e entre os termos ${ }^{-} \mathrm{s} 2 \mathrm{e}^{-} \mathrm{s} 2$.

No eixo vertical, ocorre a relação de implicação entre os termos complementares ${ }^{-} \mathrm{s} 1$ e s2, e entre os termos ${ }^{-} \mathrm{s} 2$ e s1.

Esse modelo pode ser revestido das mais diferentes formas, por exemplo: 


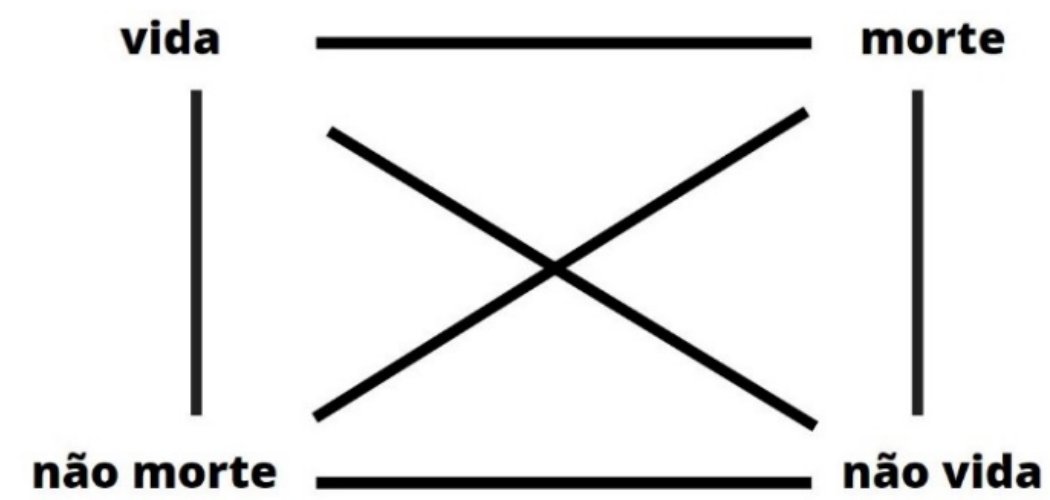

- Regimes de construção da realidade

Além do percurso gerativo do sentido para a análise dos romances experimentais, para a elaboração da nossa tipologia, nós adotaremos o modelo teórico proposto por Jean-Marie Floch, em Sémiotique, marketing et communication (1990). Em "Tués dans l'oeuf!", Floch trabalha com quatro ideologias de construção da realidade, que identifica ao analisar o discurso publicitário. Essencialmente, nós iremos observar quais desses regimes de construção do real predominam em cada uma das obras do nosso corpus, e como elas dispõem seus temas e figuras em relação às imagens do mundo.

Em sua análise dos discursos publicitários, Floch parte do quadrado semiótico, e da oposição semântica entre publicidade referencial vs publicidade mítica - no primeiro caso, os temas e figuras se assemelham às imagens do mundo, como na pintura figurativa ou na literatura do realismo; no segundo, os temas e figuras são trabalhados não à semelhança das imagens do mundo, mas conforme a lógica interna dessas obras, como na pintura surrealista ou na literatura de ficção científica. Dessa oposição, referencial vs. mítico, surgem dois outros regimes de construção da realidade, o oblíquo e o substancial. O oblíquo irá negar o referencial e afirmar o mítico, nele ficção e realidade perturbam nossa percepção do real; já o regime substancial irá negar o mítico e afirmar o referencial, nele se constrói uma presença física. 
A partir da análise dessas três obras, cada qual pertencente a um regime de realidade específico, nós pretendemos demonstrar como Zero constrói sua ilusão de referencialidade; como PanAmérica constrói sua obliquidade; e como Riverão constrói sua presença substancial.

\section{- Semântica global}

Além do percurso gerativo do sentido e do quadrado semiótico proposto por Floch, nós também iremos nos guiar pelas considerações de Dominique Maingueneau em Gênese dos Discursos (2008), Pragmática para o discurso literário (1996) e O contexto da obra literária (2001). Pensando a dimensão discursiva da Literatura, Maingueneau defende que o modo da enunciação "obedece às mesmas restrições semânticas que regem o conteúdo do discurso", ou seja, pela "forma da enunciação" o discurso toma "corpo", fazendo com que o enunciador não seja um mero "ponto de entrecruzamento", mas se construa com "tom, caráter e corporalidade específicos" (2008, p.92).

Segundo Maingueneau, em cada discurso da enunciação, existe um corpo textual "que jamais se dá a ver, mas está presente por toda parte, disseminado em todos os planos dos discursos" (ibidem, p.93). Daí sua concepção de semântica global, cujo

(...) caráter global dessa semântica se manifesta no fato de que ela restringe simultaneamente o conjunto dos "planos discursivos": tanto o vocabulário quanto os temas tratados, a intertextualidade ou as instâncias de enunciação (ibidem, p. 22)

Em sua visão, a obra literária deve ser analisada a partir de elementos que permitam o desvendamento de sua semântica global: a coesão que diz respeito aos encadeamentos locais na narrativa e a coerência que trata de injunções mais globais, por exemplo, os gêneros (Maingueneau, 2008, p.88). Neste trabalho, nós iremos demonstrar como essas narrativas ganham esse 
"corpo" e como se espraia, de forma coesa e coerente, no conjunto dos planos discursivos (ibidem, 1996, p. 59).

Um segundo ponto trazido pelo teórico diz respeito à relação que todo discurso estabelece com o seu Outro. Considerando que nosso corpus é inteiramente formado por narrativas experimentais, é possível identificarmos nesse "Outro" o discurso da convenção, da norma, da tradição. Como aponta Maingueneau, o Outro "não deve ser pensado como uma espécie de invólucro do discurso", mas sim como seu oposto. É em oposição a ele que o discurso se afirma, ou melhor, a existência do Outro está implícita na constituição de um "mesmo/eu" (2008, p. 31). Esse Outro, complementa Maingueneau, é "a parte de sentido que foi necessário o discurso sacrificar para constituir sua própria identidade", e, neste sentido, cada discurso detém uma "zona de interdito" em outro discurso, o que torna o seu dizer legítimo. "Todo enunciado do discurso rejeita um enunciado, atestado ou virtual, de seu Outro do espaço discursivo" (ibidem). Instaurada no discurso, a narrativa experimental estará sempre em relação à convenção, o seu Outro discursivo.

Por fim, importante salientar que trabalhar com o discurso literário e experimental, produzido em meio ao terror de Estado, exige que articulemos diferentes campos de estudo. É por isso que, além das teorias de Greimas, Floch e Maingueneau, nós nos apoiamos na contribuição de outros semioticistas, linguistas, críticos literários, historiadores, economistas, filósofos e cientistas políticos.

\section{Percurso do trabalho}

Nós apresentaremos nossa tipologia em quatro capítulos.

No primeiro capítulo, "Construir a história", nós contextualizaremos os discursos da opressão e os discursos da liberdade. Na contextualização dos discursos de opressão partiremos da visão geopolítica de Marco Aurélio Garcia (História-Unicamp), macroeconômica de Ladislau Dowbor (Economia-PUC), dos dados da Comissão Nacional da Verdade sobre o período, das análises de Venício A. de Lima (Comunicação - UnB) sobre a imprensa; e as de Marilena 
Chauí (Filosofia - USP) relativas à cultura autoritária brasileira. Para a contextualização dos discursos da liberdade, situados no âmbito amplo da resistência cultural do período, nós adotamos as contribuições de Roberto Schwarz (Teoria Literária - USP) no clássico Cultura e Política: 1964-1969, escrito entre 1969 e 1970; e dos trabalhos sobre Tropicália e Contracultura de Celso Favaretto (Filosofia - USP). Na contextualização dos discursos da liberdade, englobando a resistência cultural à ditadura no campo da Literatura, partiremos das visões de Heloisa Buarque de Hollanda (Literatura - UFRJ) sobre os movimentos de vanguarda do período; de Evelina Hoisel (Literatura - UFBA) sobre PanAmérica e Nações Unidas (1968) de Agrippino de Paula, em Supercaos (1980); das relações estabelecidas por Eurídice Figueiredo (Estudos Literários - UFF) entre Literatura e ditadura, arte e memória, romance e arquivo. Contaremos, também, com artigos de época e depoimentos de protagonistas dos movimentos culturais do período como José Celso Martinez Corrêa (Teatro Oficina) e Richard Hamilton (artes visuais), entre outros.

No segundo capítulo, "Sair do Gueto", nós iremos abordar as definições e indefinições a respeito do exercício experimental, articulando o pensamento de quem (1) pratica e pensa o experimental como o poeta português Ernesto de Mello e Castro, falecido neste 2020, e um pioneiros do experimentalismo português 5; e o escritor e ensaísta argentino Damián Tabarovsky, autor de Literatura de Esquerda (2017); duas gerações de artistas possuídos pelas vanguardas e seus fantasmas; também contaremos com a contribuição decisiva de (2) Roland Barthes cujas oposições "texto de prazer e de fruição", discurso "acrático e encrático", "texto e obra" são de grande valia na delimitação de algumas balizas dessas práticas experimentais que, de antemão, não constituem escolas e nem se pretendem estilo. Nós também iremos articular dois momentos de incidência do experimental nas artes literárias: a vanguarda de Oswald, modernista, que exploraremos com a crítica de Mário de Andrade; e a vanguarda de Agrippino, tropicalista, que exploraremos a partir das contribuições de Celso Favaretto. Nesse processo, pensaremos os diálogos entre experimento e

\footnotetext{
5 Em Portugal, "experimentalismo" diz respeito a movimento literário propriamente dito, o que não é o nosso caso. No Brasil, o que chamamos de experimentalismo refere-se, antes de tudo, à uma postura investigativa de criação literária.
} 
tradição a partir do conceito de tradição moderna do poeta e crítico literário mexicano Octávio Paz, que afirma a modernidade como força propulsora de sucessivas descontinuidades.

No terceiro capítulo, "Participar da Festa", nós analisaremos os efeitos de sentido que constroem a ilusão de realidade nas obras do presente corpus; observando como as ideologias do discurso publicitário definidos por Floch se aplicam à construção do sentido de realidade nessas obras. Para tal, iremos apresentar o modelo de Floch e a aplicação feita por Antônio Vicente Seraphim Pietroforte (Linguística-USP) deste modelo na Pintura. Em seguida, iremos observar como é construída a obliquidade em PanAmérica, a referencialidade em Zero, e a substancialidade em Riverão Sussuarana. Essas obras serão abordadas a partir das ferramentas da semiótica narrativa, em particular, o percurso gerativo do sentido proposto por A. J. Greimas, e as elucidações sobre a semiótica greimasiana trazidas por Diana Barros (Linguística- USP) em Teoria do Discurso: fundamentos semióticos (1988), José Carlos Fiorin (Linguística USP) em As astúcias da Enunciação: as categorias de pessoa, espaço e tempo (2016); e Denis Bertrand em Caminhos da Semiótica Literária (2003). Também utilizaremos as reflexões de Gerard Genette em Palimpsestos: literatura de segunda mão (2010); e os conceitos de Dominique Maingueneau desenvolvidos em Gênese dos Discursos (2008), Pragmática para o discurso literário (1996) e O contexto da obra literária (2001).

No quarto e último capítulo, "A significação no romance experimental”, nós iremos apresentar nossa proposta de tipologia a partir das contribuições de Jean-Marie Floch em Sémiotique, marketing et communication (1990), observando as relações de oposição, contrariedade e complementariedade estabelecidas entre essas obras, a partir do eixo de construção semântica entre as ideologias referencial e mítica.

Grosso modo, nos dois primeiros capítulos, iremos construir o panorama histórico e cultural dessas obras e da discussão sobre o experimentalismo. E nos dois últimos capítulos, apresentaremos uma tipologia ancorada nos modos de construção da realidade nessas obras. 


\section{Construir a História}

Janeiro de 2020. Meses depois das declarações de Eduardo Bolsonaro sobre o Al-5, por conta das manifestações chilenas; o então ministro da Educação, Abraham Weintraub, cobrado pela ausência de questões sobre a ditadura militar no Exame Nacional do Ensino Médio (Enem) de 2019, respondia:

Para mim, ditadura é isso, uma situação muito pesada. Como aqui no Brasil existe ainda uma coisa não pacificada de como foi o período do regime militar, e o objetivo do Enem não é polemizar, o banco examinador resolveu não colocar. Não é para ter questão polêmica. (Weintraub, R7, 18.01.2020)

Negando a polêmica que instaura ao censurar o tema da ditadura no Enem, desobrigando milhões de jovens do conhecimento dos fatos ocorridos durante 21 anos de arbítrio do Estado no Brasil, o ministro deslegitimava o conhecimento sobre o período militar, sedimentado e ao longo de mais de meio século, porque desde a primeira hora do golpe, as pessoas denunciaram, escreveram, exibiram seus corpos marcados pela tortura. Um saber construído, portanto, a partir de vestígios materiais (inclusive ossadas das vítimas), depoimentos e testemunhos e, também, por pesquisas acadêmicas, obras de arte e diversa bibliografia nacional e internacional.

Apesar disso, a busca pela deslegitimação desse saber, inclusive, do saber acadêmico, relegando as Humanidades ao impressionismo opinativo, como se narrativas históricas fossem questões de foro-íntimo, não tivessem método, não resultassem de vestígios históricos e acúmulo prévio de visões ao longo do tempo. No caso, além da investidura ideológica do ministro, nada justificaria a exclusão do termo "ditadura militar" no exame. Nas entrelinhas, o governo passava o recado (não é preciso estudar ditadura) não sem negar, diante das câmeras, a polêmica e o fragoroso ataque à legitimidade de um saber, tornado mentira e com ares de isenção "o banco examinador resolveu não colocar". A questão, evidentemente, não é o ministro " $X$ " ou o governo " $Y$ ", mas a presença do discurso laudatório da ditadura, sem travas e às claras, 
reverberado pelo Palácio do Planalto. E isso ocorre devido à impunidade dos crimes de lesa-humanidade cometidos naquele período e jamais assumidos, punidos ou devidamente reparados pelo Estado.

Contrariamente a países como Argentina, Chile, Uruguai, o Brasil se esquivou, ou melhor, a oligarquia empresarial e militar esquivou o país do imperativo resgate histórico e do enfrentamento dos horrores cometidos no período pelo Estado contra a população civil, de Norte a Sul. O último esforço possível resultou nas mais de seis mil páginas do relatório da Comissão Nacional da Verdade (CNV) que, entre 2011 e 2014, investigou violações aos direitos humanos, sofrendo "queima de arquivo" durante o processo: o assassinato de uma de suas testemunhas ${ }^{6}$, o ex-agente do Centro de Informações do Exército durante a ditadura, cel. Paulo Malhães, que havia confessado a tortura e o ocultamento de cadáveres. Além do brutal modo de conter a CNV, a cobertura dos veículos de comunicação foi pontual, asséptica, e muito aquém do ambiente necessário a um efetivo resgate histórico, definitivamente, não abraçado por esses veículos, e isso por distintas questões, inclusive ideológicas, afinal era o governo Dilma Rousseff, do PT, à frente disso tudo.

Ao problematizar a questão da impunidade no Brasil, Figueiredo traz o exemplo da Comissão da Verdade e da Reconciliação na África do Sul, criada por Nelson Mandela e presidida pelo Nobel da Paz, o arcebispo anglicano Desmond Tutu, em 1998. Lá como aqui, a anistia foi ampla e irrestrita, mas eles fizeram um julgamento não apoiado na punição, mas sim na exposição do crime e do culpado:

Nas audiências públicas as vítimas narravam seus sofrimentos e, por outro lado, os responsáveis por torturas e demais crimes escutavam e pediam perdão. A anistia foi concedida individualmente, com a condição de que cada um manifestasse arrependimento e pedisse perdão. Embora não tivesse havido punição para os criminosos, a anistia, neste caso, pelo menos teve a vantagem de revelar a verdade histórica e expor os criminosos ao reconhecimento público da culpa. Não se buscava tanto punir, mas reconciliar, passando por esse exercício

\footnotetext{
${ }^{6}$ Em 25 de abril de 2014, o ex-agente do Centro de Informações do Exército, coronel Paulo Malhães foi encontrado morto, um mês depois de prestar depoimento à CNV, confessando ter torturado, matado e ocultado cadáveres (Carta Capital, 2014, online).
} 
coletivo de memória, numa espécie de cerimônia de exorcismo e catarse que possibilitaria um recomeço na vida nacional (Figueiredo, 2017, p.24).

Esse processo de reconciliação foi negado ao Brasil. Apesar de significar os mais variados recomeços, nosso processo de redemocratização nunca conseguiu promover, na escala necessária, sua "cerimônia de exorcismo e catarse", capaz de possibilitar "um recomeço na vida nacional", pela exposição dos crimes e dos culpados.

Em abril de 2010, o Supremo Tribunal Federal (STF) impediu definitivamente esse processo, ao reafirmar a legitimidade da Lei de Anistia (promulgada ainda sob a ditadura, em 1979), mantendo impunes os crimes de outrora e seus responsáveis. Medida que, oito anos depois, garantiria o livretrânsito de vários desses criminosos por instâncias decisórias e de comando no país. Como diria Tom Jobim em sua célebre frase, "o Brasil não é para principiantes".

Arqueologias de sentidos, PanAmérica, Zero e Riverão Sussuarana nos permitem acessar não o momento - o que seria impossível -, mas os discursos e as tensões entre a liberdade e a opressão, em meio a violações aos direitos humanos. Essas questões serão trabalhadas por esses romances, a partir de experimentações várias com a linguagem verbal. A mais evidente delas é o alto grau de fragmentação da narrativa, que perde sua linearidade, permitindo inventivos modos de redistribuição e ordenamento dos temas e das figuras, todos relacionados à contemporaneidade dessas obras. Daí a necessidade de estabelecermos um breve panorama do contexto em que elas foram produzidas.

Em 1967, quando PanAmérica é publicada, o cerceamento das liberdades individuais e coletivas se intensifica. A Constituição de 1967 já preparava o terreno para o Al-5, suspendendo as eleições livres e diretas no país. Esse momento, dada a crescente redução das liberdades individuais e coletivas, será marcado pela polarização ideológica, por passeatas e marchas da esquerda e da direita, pela entrada em cena dos tropicalistas, da televisão na sala de estar, do Jornal Nacional da Rede Globo, dos embates calorosos nos chamados Festivais da Música Popular Brasileira. É o momento da vanguarda política- 
cultural, assumida pelos artistas de teatro em parceria com o movimento estudantil, contra a repressão militar que prendeu lideranças populares e trabalhadores desde 1964. Trata-se de um contexto de intensa vitalidade e explosão criativa que seria, um ano depois, completamente varrido do horizonte com a violência do Al-5.

Em 1975, sete anos após o Al-5, quando Zero é lançado, o ambiente era totalmente adverso. O aparato de terror e a política de eliminação dos desafetos e opositores do regime estão estruturados. É mais um ano de "milagre econômico", e o jornalista Vladimir Herzog é morto sob tortura nas dependências do DOI-Codi (Destacamento de Operações de Informações do Centro de Operações de Defesa Interna) do $2^{\circ}$ Exército em São Paulo. São os chamados "anos de chumbo", período de perseguições, exílios, assassinatos. Quando trabalhadores da cidade e do campo, militância de esquerda ou progressista, intelectuais, artistas, religiosos são ameaçados em seu cotidiano, obrigados a conviver com interventores ou agentes do regime em redações de jornal, sindicatos, empresas, universidades e cargos do poder público.

Em 1978, quando Glauber Rocha publica Riverão Sussuarana, o Al-5 era extinto, pelo menos oficialmente, e o direito ao habeas corpus devolvido à população. Um ano depois, em 1979, seria promulgada a Lei de Anistia e os exilados políticos começavam a retornar ao país. Ao mesmo tempo, debaixo dos helicópteros do Exército, as manifestações estudantis voltavam às ruas e as greves do $A B C$ reacendiam a luta da massa trabalhadora que, além da polícia, também enfrentava o poder das multinacionais aqui instaladas, e dos chamados "pelegos" nos sindicatos. A abertura política acenava no horizonte, mas seriam necessários mais sete anos de ditadura, dez até a promulgação da nova Constituição; e onze anos para que os brasileiros elegessem diretamente o presidente da República.

Por trabalharem com personagens e episódios de sua contemporaneidade, essas obras nos oferecem um impactante registro dos 21 anos de ditadura militar, os mesmos que, em grave descompromisso com lutas históricas pela liberdade, o ministro da Educação de Bolsonaro, procurou abafar. Além disso, são textos que englobam os anos 1960 e 1970, duas décadas 
cindidas pela Guerra Fria, quando duas superpotências militares e ideológicas, os Estados Unidos e a União Soviética, resolveram fazer do restante do mundo o palco de suas batalhas, aliás, dessa nova modalidade de Guerra, nem a Lua escapou.

É quando surge o rock in roll, o movimento punk, o movimento hippie, o movimento pop, a poesia beat, a Tropicália, o tropicalismo, o underground, a arte psicodélica e tantas outras leituras do real. Quando a pílula anticoncepcional chega nas farmácias (1960), o homem na Lua (1969) e o Relatório Hite nas bancas (anos 1970). Quando os cubanos tomam o poder na Ilha (1959) e os Estados Unidos, alinhados com as elites econômicas dos países da América Latina, promovem a queda sistemática de democracias em todo o continente. Tempos de Primava de Praga (1968), Maio de 68, Festival de Woodstock (1969) e da explosão das marchas, manifestações, passeatas por direitos civis, trazendo à cena revolucionária os movimentos negro, feminista, LGBT. É quando, após séculos, os europeus são finalmente expulsos pelos africanos, em sangrentas lutas pela independência; e os Estados Unidos são derrotados pelos vietnamitas em 1975, perdendo, e para todo o sempre, a aura de país predestinado. E essa página poderia seguir à exaustão, caso elencássemos todos os acontecimentos que marcaram a convulsão política, social, artística e comportamental daquele período. Por ora, fiquemos com a contribuição de Marco Aurélio Garcia, historiador e estrategista da política externa brasileira durante a Era Lula (2003-2010).

Em Rebeldes e Contestadores: 1968 - Brasil, França e Alemanha (1998) analisando o ano emblemático de 1968, Garcia reúne a efervescência daquele período em três dimensões: a anti-imperialista, a anticapitalista e as crises dos governos soviéticos. A dimensão anti-imperialista abrange as lutas no então chamado "Terceiro Mundo"7, como a resistência contra a ditadura militar no Brasil e na América Latina, as lutas pela independência nos países africanos, tendo na Guerra do Vietnã um caso emblemático, propulsor de forte sentimento anti-imperialista, por meio de protestos (movimento pacifista, movimento hippie, festival de Woodstock) e ações em diversas partes do globo. Não à toa, em

7 Posteriormente chamados de "países subdesenvolvidos" e atualmente "países em desenvolvimento" como o caso do Brasil. 
mensagem à Conferência Tricontinental, Che Guevara (morto em 1967) convocava os revolucionários a criarem "dois, três, muitos Vietnãs". Sob a ingerência norte-americana no mundo:

Sob a palavra de ordem "não permitiremos outra Cuba", oculta-se a possibilidade de agressões a esgalha, como a perpetrada contra Santo Domingo ou, anteriormente, o massacre do Panamá, e a clara advertência de que as tropas ianques estão prontas a intervir em qualquer lugar da América onde a ordem estabelecida for alterada, pondo em perigo os seus interesses. É política que conta com uma impunidade quase absoluta; a OEA é uma máscara cômoda, por desprestigiada que esteja; a ONU é duma ineficiência próxima do ridículo ou do trágico, os exércitos de todos os países da América estão prontos a intervir para esmagar os seus povos. Formou-se, de facto, a internacional do crime e a traição. De outra parte, as burguesias autóctones perderam toda a sua capacidade de oposição ao imperialismo - se alguma vez a tiveram e só são seguidistas do mesmo. Não há mais mudanças a fazer; ou revolução socialista ou caricatura de revolução. (Che Guevara, Havana, 04.04.1967)

Aliás, a própria Revolução Cubana (1959) e as sucessivas lutas, até muito recentemente, travadas pela Ilha contra o embargo econômico norte-americano, expressam a dimensão anti-imperialista, tematizada nas narrativas do presente corpus que citam o país ou usam elementos da cultura estadunidense para caracterizar seus antagonistas. Essa dimensão tem forte impacto quando, em 1975, dá-se a anexação de Saigon pelos comunistas do Vietnã do Norte, ferindo fragorosamente a imagem dos Estados Unidos no mundo.

Além da dimensão anti-imperialista, predominante nos países em desenvolvimento, em resposta às ingerências das superpotências durante a Guerra Fria, Garcia menciona uma segunda dimensão, a anticapitalista que predominou nos países desenvolvidos e tem em "Maio de 68" seu emblema. Revolvendo toda sorte de questionamentos sobre as relações de poder na sociedade capitalista, a sequência de eventos que caracteriza o Maio francês expressa, aponta o historiador, o sentimento de que a sociedade industrial havia minado a capacidade contestatória de seus principais atores sociais, em especial a da classe operária, daí o protagonismo da juventude e a eclosão de novos 
atores e bandeiras de luta, como a luta das mulheres, dos negros, dos gays dando novo fôlego e densidade à utopia revolucionária.

O suposto deslocamento da classe operária do centro dos acontecimentos era compensado pela emergência de novos sujeitos, ao mesmo tempo portadores de novas problemáticas, muitas delas até então consideradas 'pré-políticas'. As relações de exploração deixavam de ser, para algumas interpretações, o elemento explicativo fundamental das contradições sociais. Eles cediam lugar a relações de dominação, não necessariamente fundadas em fatores econômicos, pelo menos de forma expressiva (Garcia, 1998, p.21).

Ativo participante do maio francês, Edgar Morin (pesquisador emérito do Centre National de la Recherche Scientifique) observa como aspecto comum às diferentes lutas o fato delas se levantarem "contra a autoridade dentro dos diferentes sistemas". Em sua avaliação,

\begin{abstract}
Há uma tradição de revoltas estudantis, mas nunca nada comparável a 68. O acontecimento, no meu ponto de vista, é contraído em 1988, quando acontece o fim do comunismo, termina a guerra fria. Tenho a impressão que Maio de 68 é algo assim como um momento simbólico de crise da civilização, onde surgem algumas aspirações profundas, quase antropológicas (mais autonomia, mais comunidade), que declinam e renascerão sob outras formas. Minha opinião é que muitas coisas mudaram sem que nada mudasse. Sobretudo, no plano dos costumes, dos sentimentos, das ideias. $E$ quero recordar que a classe adolescente já havia se formado antes de Maio de 68 e que foi a que permitiu seu impulso. (Morin, Clarin Revista N, 04.05.2018)
\end{abstract}

Essa crise da civilização estará fortemente ligada à terceira dimensão salientada por Garcia: a crise das experiências socialistas. Período de forte crítica e autocrítica das esquerdas em todo o mundo, permeado de manifestações e sublevações nos países do Leste Europeu e, também, na China. Ícone dessa dimensão, a "Primavera de Praga" (1968) - período de liberalização política na Tchecoslováquia - precisa ser analisada à luz do XX Congresso do Partido Comunista da União Soviética, de 1956, aponta Garcia. Afinal, foi nesse Congresso que Nikita Kruchev, Primeiro Secretário do PC, 
denunciou os desmandos do regime sob Stalin, em discurso ${ }^{8}$ para 1.500 delegados. Alto escalão do partido, Kruchev responsabilizava Stalin, morto três anos antes, por uma série de erros de gestão e pela brutal repressão de seus oponentes, inclusive prisões e assassinatos de combatentes de 1917, fundadores do comunismo soviético. Apesar da tentativa, conta Garcia, Kruchev não conseguiu promoveu nenhuma reforma na URSS, porém, "o pouco que fez foi suficiente para provocar a reação da burocracia partidária que o destituiu em 1964, em um autêntico golpe de Estado" (Garcia, 1998, p. 15).

Essas três dimensões - anticapitalismo, anti-imperialismo e a crise das experiências soviéticas - perpassam os romances aqui analisados e, em particular, o anti-imperialismo. Os Estados Unidos e os símbolos da cultura norteamericana são constantemente mencionados nesses textos que, também, expõem as mazelas do subdesenvolvimento brasileiro. Além disso, essas obras trazem profunda identidade latino-americana. Quanto ao questionamento da autoridade e das relações de poder no capitalismo, são obras que exalam não o aroma, mas o espírito de 68 que desvelou e, com muita arte, as hipocrisias do seu tempo. Historiador, participante ativo das lutas contra a ditadura militar e, anos depois, juntamente com Celso Amorim, responsável pela política externa "altiva e ativa" da era Lula, Garcia traz sensível definição do "espírito de 68":

Não há como esquecer que foi naquele momento que milhões de homens e mulheres tiveram o sentimento de estarem construindo a história e não apenas de serem vítimas de forças do destino que não conseguem visualizar, quanto mais entender. Para muitos, esse fazer a história significou entregar a própria vida ou submeter-se a enormes sacrifícios pessoais. Em 1968 não havia lugar para pensamos únicos e interdições, até porque "era proibido proibir". Que tudo tenha tido o aspecto de uma grande quermesse, nada contra. A grande historiadora francesa Michelle Perrot já havia ensinado como a greve, ainda no século XIX, era vivida pelos operários como uma "festa" (Perrot, 1974). A luminosidade de 1968 contrasta com a opacidade dos anos e décadas seguintes. As esperanças que suscitou nos que viveram aqueles

\footnotetext{
8 O discurso de Khrushchev, "Sobre o culto à personalidade e suas consequências", também conhecido por "Discurso Secreto" ou "Relatório de Khrushchev", pode ser lido, em inglês, no site do The Guardian em < https://www.theguardian.com/theguardian/2007/apr/26/greatspeeches1 > Acesso em 11 ago 2020.
} 
tempos difere da desesperança dos tempos presentes que conduzem ao conformismo e à servidão voluntária" (ibidem, 1998, p.17, grifos nossos).

Pilares desse espírito, o sentimento de construir a história e o de participar da "festa" revolucionária estruturam as narrativas e as trajetórias dos autores aqui analisados. Tanto Glauber Rocha quanto Agrippino de Paula e Loyola Brandão participaram e influenciaram o circuito cultural de sua época. Em 1979, Glauber já era o gênio do cinema nacional e um dos principais nomes do Cinema Novo. Em 1975, Loyola já era jornalista e Zero teve sucesso imediato, rodando o mundo, com contundente denúncia sobre a ditadura brasileira. Em 1967, Agrippino de Paula já havia publicado Lugar Público (1965), e estava envolvido com teatro, circulando entre os tropicalistas, quando lançou sua PanAmérica que viraria verso em "Sampa" de Caetano Veloso, e canção no álbum "Novos Baianos". São obras que expressam o pensamento de artistas que viveram o calor daquele momento, chamando para si - e para a Literatura - a tarefa de construir a história e de participar da festa.

De modo geral, essas três dimensões (anticapitalismo, anti-imperialismo e a crise das experiências soviéticas) serão revestidas conforme dois campos discursivos muito bem delimitados: os discursos da opressão, sejam elas econômica, política ou cultural; e toda gama de discursos da liberdade trazidas por estas e outras poéticas da liberdade, como veremos a partir de agora.

\subsection{Discursos da Opressão}

Ao longo de quatro décadas de Guerra Fria, os Estados Unidos e a União Soviética nunca se enfrentaram a céu aberto, pelo contrário, terceirizaram o conflito que estourou no território de diversos países, em particular, os da América Central e Latina, desde o Corolário Roosevelt ${ }^{9}$ de 1904 , concebidas

\footnotetext{
9 Postulado de política externa expresso por Roosevelt, em 1904, ao Congresso norteamericano, o Corolário Roosevelt comunicava aos países da América Central e Latina que, dali por diante, os Estados Unidos garantiriam a independência da região, podendo inclusive intervir na direção desses países.
} 
pelos EUA, como zona geográfica de influência norte-americana. Sob estridentes bandeiras da Guerra Fria, além do Brasil, com o beneplácito de elites locais, ditaduras foram instauradas no Brasil (1964-1985), na Argentina (19661973), Chile (1973-1990), Uruguai (1973-1985), Paraguai (1954-1989), Bolívia (1964-1980), apenas para nos restringirmos às nações-alvo da Operação Condor, que tinha como principal objetivo o alinhamento ideológico (e econômico) da região aos Estados Unidos, o que significou a eliminação, pura e simplesmente, de qualquer resistência. Em O dia que durou 21 anos (2012), documentário dirigido por Camilo Tavares, com produção de Flávio Tavares um dos grandes jornalistas do Zero Hora naqueles tempos -, é possível acompanhar como aconteceram esses acordos.

De forma dinâmica e didática, combinando animação e documentos de época, do Brasil e dos órgãos de segurança dos EUA, o documentário traz revelações importantes, com material inédito, que mostra o papel de Lincoln Gordon, embaixador norte-americano no Brasil entre 1961 e 1971, no processo de intervenção dos Estados Unidos na política brasileira. João Goulart, exministro do Trabalho de Vargas, alçado presidente após a renúncia de Jânio Quadros, é pintado por Gordon às autoridades norte-americanas, em conversas telefônicas, telegramas e ofícios, como empedernido comunista; e suas reformas de base, na prática, políticas públicas voltadas a minimizar históricas desigualdades sociais e regionais do país, apresentadas como provas incontestes do perigo esquerdista na América Latina.

Longe de pensarmos o que seria do Brasil hoje, caso essas reformas tivessem sido realizadas, o ponto central aqui é que elas efetivamente contrariavam os interesses norte-americanos para a região. Quais interesses eram esses? Em A Formação do Terceiro Mundo (1994), Ladislau Dowbor (Economia - PUC SP) traz um olhar sistêmico e macroeconômico sobre o período. Ele explica que, antes da II Guerra Mundial, o mundo era dividido conforme as necessidades industriais e econômicas das metrópoles europeias. A África, por exemplo, seus países e povos foram desmembrados entre as nações europeias, conforme seus minérios e matérias-primas. Essa repartição do mundo, conhecida como "imperialismo" se transformaria frente ao surgimento de outra forma de exploração entre as nações: a empresa transnacional, 
novidade que passa a ditar as relações e regras do mercado mundial (Dowbor, 1995, p.29).

Entre 1930 e 1950/1960, explica Dowbor, os países industrializados investiram recursos na elevação social e melhoria da renda de suas populações para atender a demanda de mercado exigida pela industrialização e a produção em grande escala do pós-Guerra. Esse movimento ocorre também nos países em desenvolvimento, como os processos de industrialização no Brasil entre Vargas e Jango. Daí o slogan "50 anos em 5" de Juscelino.

Acontece, porém, que diferentemente das potências mundiais, nos países em desenvolvimento, esse processo ocorre a reboque das grandes potências. $A$ partir da II Guerra, as economias dos países subdesenvolvidos são tratadas pelas potências, em particular os Estados Unidos, como economias complementares à dinâmica de seus próprios mercados internos. As empresas transnacionais, mantendo a sede em seus países de origem, instalam-se nos territórios do Terceiro Mundo, contando com uma série de facilidades: abundância de matérias-primas (água, minérios, terras etc.), mão-de-obra mais barata e mais facilmente explorada do que os trabalhadores em seus países de origem, além das benesses várias, como por exemplo o sumiço de lideranças sindicais e populares. Com esse modelo, explica Dowbor, as perdas sofridas pelos países industrializados, durante o processo de formação de seus mercados internos entre 1930 e 1960, foram ressarcidas nas décadas seguintes, graças aos custos mais baratos de produção nos países subdesenvolvidos e, posteriormente, pelo endividamento desses países junto às nações desenvolvidas (ibidem, p.30-31). Evidentemente, pondera o economista, a instalação dessas empresas promoveu desenvolvimento nessas localidades, mas

a industrialização no Terceiro Mundo nunca foi realmente refletida, organizada ou muito menos planificada: deu-se num processo objetivo, processo em que dominou, naturalmente, a força dos mais desenvolvidos. Substituímos importações, mas as substituímos por outras, com maior valor tecnológico incorporado (ibidem, p.34). 
À revelia dos imensos problemas regionais desses territórios - fossem eles ecológicos, sociais, históricos ou políticos - o desenvolvimento do Terceiro Mundo implicou o controle total pelas transnacionais de setores-chaves da economia e das finanças dessas regiões, fazendo com que esses países ocupassem um lugar de complemento na periferia da globalização mundial (ibidem, p.32-33). Ao priorizar a monocultura (de baixo valor agregado) e a exportação de matérias-primas, os governos militares aprofundaram a dependência econômica do Brasil. Além disso, a concentração de infraestruturas modernas, em determinadas localidades e não em outros, gerou imenso êxodo rural, aprofundando as desigualdades regionais e, sobretudo, sociais, conforme se pode verificar no gráfico abaixo, relativo ao índice Gini nos últimos cinquenta anos:

Figura 3: Índice de Gini - 1960 a 2011

\section{Visão de Longo Prazo Desigualdade (Gini)}

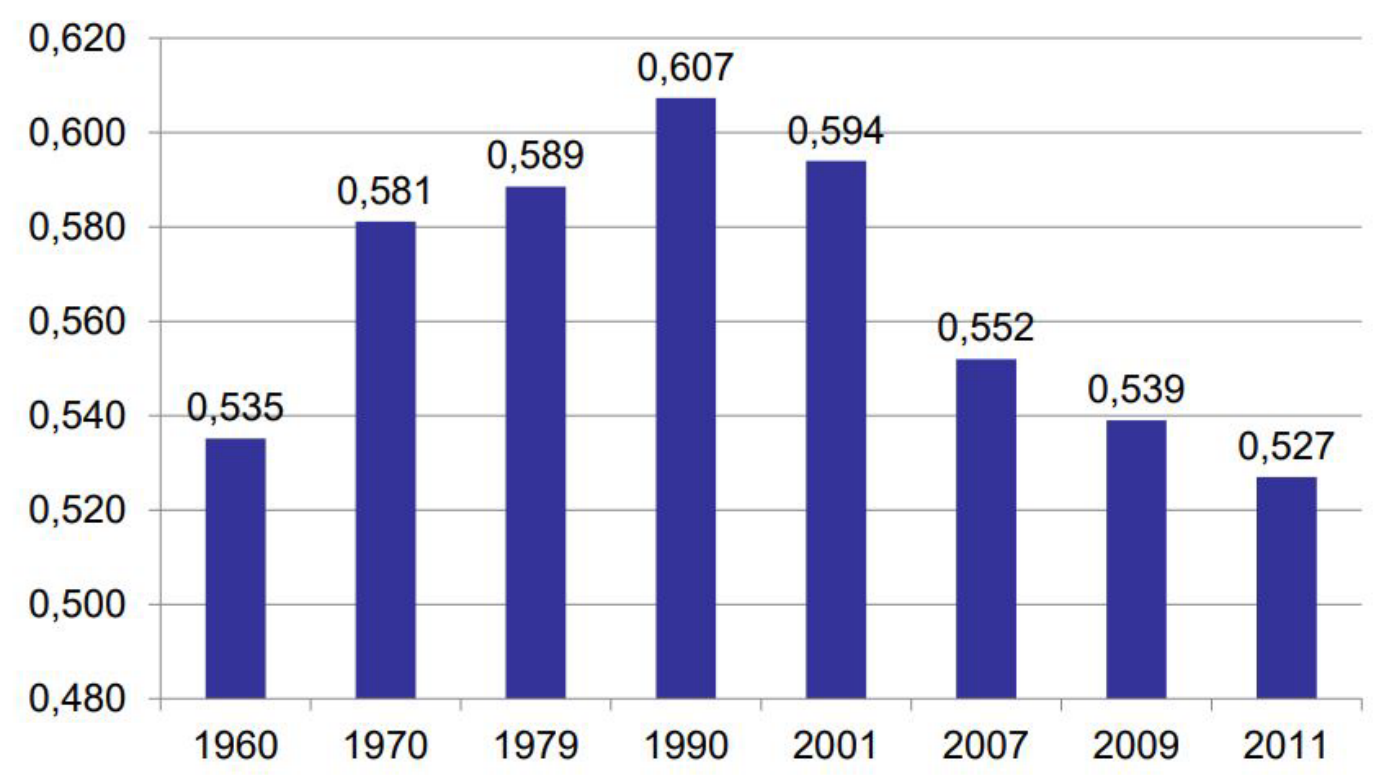

Fonte: Ipea a partir dos microdados da PNAD e Censo / IBGE e Langoni 1973

Fonte: Marcelo Neri (FGV, 2012) 
Utilizado para medir a desigualdade e distribuição de renda, o Coeficiente de Gini consiste em um número entre 0 e 1, onde 0 corresponde à completa igualdade e 1 à completa desigualdade. É notório, portanto, inclusive nos anos do chamado "milagre econômico", entre 1969 e 1973, o crescimento da desigualdade. Em Zero, de Ignácio de Loyola Brandão, o quadro acima é figurativizado de modo contundente, expressando as reais condições de vida da massa paupérrima de trabalhadores, vítimas diretas do aprofundamento das desigualdades sociais e rendas, durante o propalado "milagre econômico" (196973), como nos mostra o gráfico abaixo:

\section{GRÁFICO DO OPERÁRIO PEDRO}

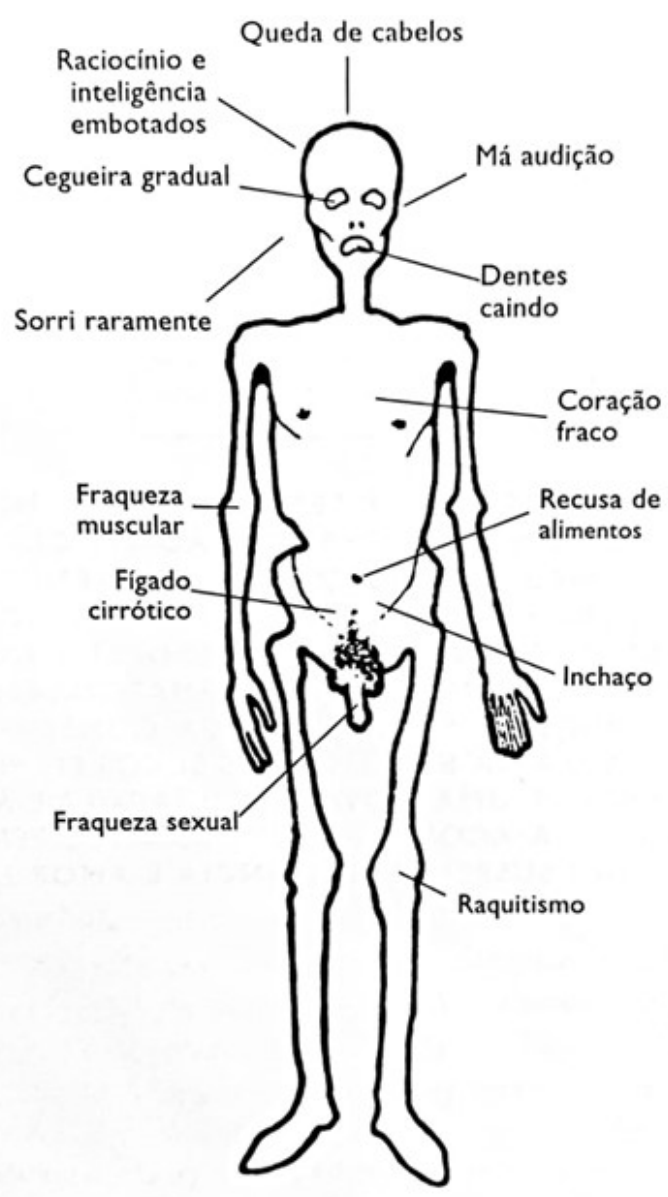

$\left(\right.$ Zero $^{10}$, p.159)

${ }^{10}$ Ao longo deste trabalho, as citações de corpus obedecerão ao seguinte padrão: primeira palavra do título da obra, seguida da numeração: PAN, p.; Zero, p.; Riverão, p. 
Apresentado de forma categórica, graficamente impresso, para que não reste dúvidas sobre o operário Pedro, a imagem acima inscreve a linguagem visual na narrativa verbal (do romance), para expressar o esgotamento das forças vitais da personagem. Faltam-lhe cabelos, audição, dentes, vigor no coração, olhos, raciocínio e inteligência. Pedro é incapaz de comer, de ter relação sexual, de pensar direito, de sorrir e, obviamente, de trabalhar. O gráficodiagnóstico traz, também, o apagamento de sua condição de operário (indicadas pelo título do gráfico): Pedro agora é peça descartada da engrenagem capitalista, o operário exaurido da força de trabalho, o homem condenado pela falência dos órgãos à exclusão absoluta. Prova cabal da brutalidade de um sistema de exclusão dos mais pobres que, embora não tenha sido criado pela ditadura, por conta dela foi extremamente aprofundado no país.

\section{- Terror como política de Estado}

Recursos naturais abundantes, mão de obra barata, mercado consumidor e governo empenhado em fechar sindicatos, prender lideranças sociais, camponesas e trabalhadoras. Não espanta que as transnacionais tenham financiado o aparato de terror do Estado militar, conforme mostram investigações da Comissão Nacional da Verdade (CNV), por exemplo, a Operação Bandeirantes (Oban) ${ }^{11}$ :

Em 1 de julho de 1969 foi criada, em São Paulo, a Operação Bandeirantes (Oban), financiada por multinacionais como o Grupo Ultra, Ford e General Motors. A cerimônia de criação da Oban contou com a presença das principais autoridades políticas do estado de São Paulo, como o governador Roberto Costa de Abreu Sodré; o secretário de Segurança Pública Hely Lopes Meirelles, o prefeito da capital, Paulo Salim Maluf; o comandante do II Exército, general José Canavarro Pereira; além de figuras proeminentes na elite econômica paulista, oriundas dos

\footnotetext{
11 O tema do financiamento empresarial da estrutura de terror, com direito a empresários assistindo a sessões de tortura nos órgãos de repressão, é abordado em Cidadão Boilesen, documentário de Chaim Litewski (2009).
} 
meios empresarial e financeiro, como Antônio Delfim Netto, Gastão Vidigal, Henning Albert Boilesen, Luiz Macedo Quentel e Paulo Sawaya. (CNV, 2014, p.127).

Além de demonstrar o quão civil foi a ditadura militar brasileira, uma das principais contribuições da CNV foi esclarecer que as graves violações aos direitos humanos, perpetradas durante duas décadas, não se constituíram em ações isoladas ou pontuais, mas "ação generalizada e sistemática do Estado brasileiro", pela qual "a eliminação de opositores políticos se converteu em política de Estado" (ibidem, p.963).

Tratou-se, portanto, de estrutura concebida e implementada pela presidência da República, "operacionalizada através de cadeias de comando", mobilizando "agentes públicos para a prática sistemática de detenções ilegais e arbitrárias e tortura, que se abateu sobre milhares de brasileiros" (ibidem). Uma política voltada à eliminação de opositores políticos "em um contexto generalizado e sistemático de ataque do Estado contra a população civil" que se abateu sobre "homens, mulheres, crianças, adolescentes e idosos, vinculados aos mais diferentes grupos sociais, como trabalhadores urbanos, camponeses, estudantes, clérigos, dentre tantos outros" (ibidem, p.964).

Quatro anos após o lançamento do relatório da CNV, em maio de 2018, o professor de Relações Internacionais da Fundação Getúlio Vargas (FGV), Mathias Spektor ${ }^{12}$, divulgava documento da CIA, liberado pelo Departamento de Defesa dos Estados Unidos, que atesta o comando do general Ernesto Geisel (1974-1979) sobre essa máquina de extermínio. A revelação desses documentos impactou o debate historiográfico sobre Geisel porque, até então, o desmonte dessa máquina era dado como um de seus objetivos, visando a transição da ditadura explícita para uma democracia ainda sob controle militar.

O impacto desse aparato de terror na esfera cultural é imensurável. A inteligência do período - pensadores, artistas, militantes, cientistas, personalidades políticas, lideranças e protagonistas da luta social - foi presa, morta ou exilada, criando imenso refluxo na atmosfera crítica e progressista.

\footnotetext{
12 Trata-se de documento secreto de 1974, liberado pelo Departamento de Estado dos EUA, que traz declaração de chefe da CIA afirmando que Geisel aprovava a continuidade da política de execuções sumários de adversários da ditadura (FSP, 10.05.2018).
} 
Retrocesso potencializado pelo sucateamento do ensino público ${ }^{13}$ e sua abertura à iniciativa privada, gerando duas educações: a pública, voltada à formação básica da mão de obra trabalhadora; e a privada, voltada aos que podem pagar seu ingresso e permanência nas universidades públicas. Situação agravada pela repressão às universidades que, desde a primeira hora do golpe, teve vários de seus professores presos, como João Battista Villanova Artigas, Paulo Duarte, Florestan Fernandes, entre outros.

Em meio a esse contexto, a resistência se organizou como pode. Trabalhadores rurais, na mira de jagunços pagos por coronéis, que já lutavam contra toda sorte de exploração. Operários e sindicalistas vítimas de prisões, fechamento de sindicatos e/ou sob comando de interventores que institucionalizaram o "peleguismo" sindical, ao gosto e à serviço das transnacionais. Jovens universitários e secundaristas que tomaram a dianteira das mobilizações, promovendo congressos clandestinos, ocupação de universidades, atos, marchas, atividades culturais. Artistas, pensadores, quadros políticos, intelectuais, cientistas, professores, em suma, formadores de opinião com papel crucial na denúncia do golpe. Lideranças religiosas, como os padres da Teologia da Libertação que se rebelaram contra as determinações de Roma. Aliás, sob o papa João Paulo II, propalou-se forte perseguição contra esses religiosos.

O terror de Estado, importante destacar, não recaiu somente sobre os que assumiram os riscos da resistência armada. O relatório da CNV detalha a história de assassinatos e torturas de camponeses, indígenas, trabalhadores dos mais diversos setores, população negra e pobre (como acontece até hoje), além de indivíduos considerados "desviantes" segundo o arbítrio dos agentes de Estado. Impulsionados, portanto, por convicções éticas e ideológicas, por lutas sociais que já vinham travando ou pela indignação, os que resistiram à ditadura, civis dos mais variados grupos e setores sociais, atenderam ao "sentimento de construir a história" (Cf. Garcia, 1998), tendo suas vidas completamente alteradas. Transformados em "inimigos da nação", "terroristas perigosos",

\footnotetext{
${ }^{13}$ Acompanhada de baixo investimento estadual nas escolas públicas. A abertura da educação para o ensino privado foi garantida pela Carta de 1967, formalizada na Emenda n.1 de outubro de 1969.
} 
"assassinos implacáveis", a imagem dessas pessoas era fixada em muros, pontos de ônibus, publicada nos principais jornais do país, como vemos abaixo:

Figura 4: Terroristas procurados

\section{TERRORISTAS PRUCURADOS ASSALTARAM-ROUBARAM-MATARAM PAIS DE FAMílla}

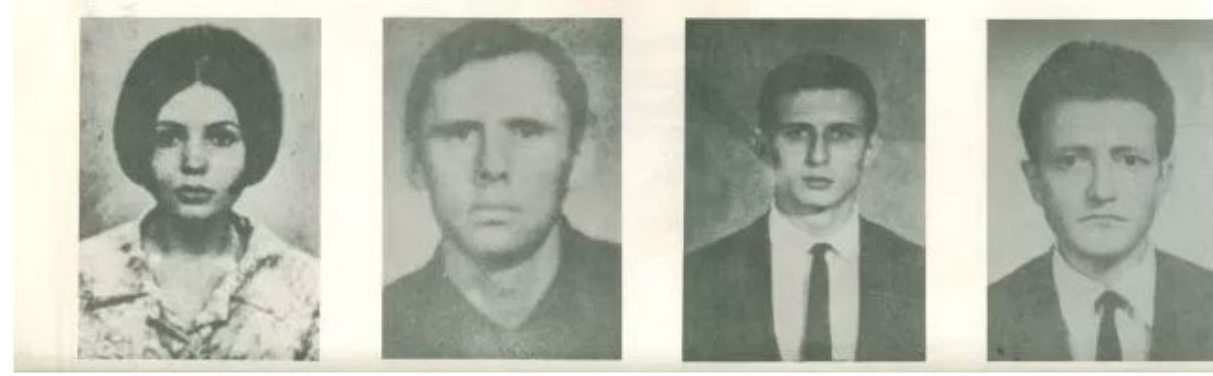

Fonte: Acervo pessoal LD

A criminalização da resistência à ditadura, presente até hoje, foi fortemente potencializada pela emergência da televisão, nova tecnologia na época, de fundamental importância no controle da opinião pública.

\section{- Aparato ideológico}

Neste país de dimensões continentais, a televisão foi peça chave para a disseminação do discurso ufanista do regime militar, dos seus mocinhos e, sobretudo, seus bandidos - "a esquerda", "os comunistas" -, dando corpo à isotopia temática do "inimigo interno".

Em Mídia, Teoria e Política (2001), Venício A. de Lima (professor emérito da UnB) aborda o impacto da televisão sobre os brasileiros. Nova tecnologia do período, capaz de: 
(1) Quebrar a "necessidade de conexão entre presença física e experiência". Com imenso poder de "construir o real", a partir da televisão não é mais necessário "estar presente para experimentar, presenciar" o fato;

(2) Transformar o homo sapiens em homo ocular. "Vemos televisão em vez de ouvi-la; nos sentimos bem ou mal, em vez de pensar sobre seus argumentos; respondemos a ela emocionalmente e não racionalmente";

(3) Desenvolver um senso de intimidade junto a pessoas e fatos distantes. "É o que se denomina 'intimidade distante' e nos leva a responder a eventos e pessoas em termos de sua aparência, de seus gestos e da emoção";

(4) Dificultar a distinção entre ficção e realidade. "Mesmo os telejornais são ficções construídas, com imagens que 'acontecem' somente na televisão. O replay de um gol numa partida de futebol mostra um lance que não foi visto por ninguém no estádio. Nem por jogadores, nem por juízes. É um gol exclusivo da televisão";

(5) Construir a cultura mítica no mundo contemporâneo. A televisão assume o papel de manutenção e reprodução dos mitos de outrora, sobretudo, por meio da narrativa melodramática (Lima, 2001, p.195-196).

Em suma: as forças envolvidas com o golpe de 1964, assim como as forças reacionárias hoje frente à Internet, viram-se diante de uma potente tecnologia de comunicação de massas, a televisão, capaz de criar o real, confundir ficção e realidade, impulsionar reações emocionais e não racionais e construir uma mítica veiculada de Norte a Sul do país. É compreensível, portanto, que a ditadura militar tenha investido pesado na televisão com vistas à disseminação de seu discurso. Restavam, porém, dois imensos desafios, conta Lima. 
O primeiro: como massificar a televisão em um país de dimensões continentais como o Brasil? Entre 1950 e 1960, o número de televisões nos lares brasileiros não ultrapassava 2 milhões de unidades. Lima destaca três esforços nesse sentido: investimento pesado na indústria eletroeletrônica; criação de um programa de crédito ao consumidor facilitando a compra dos aparelhos; e inauguração, em 1969, da Embratel (Empresa Brasileira de Telecomunicações) que criou as condições necessárias à edificação de um sistema nacional de telecomunicações. Resultado: em apenas um ano, notadamente 1968, os 2 milhões de televisores saltaram para 4 milhões (ibidem, p.156).

O segundo desafio foi encontrar na iniciativa privada uma empresa alinhada às diretrizes do regime militar para assumir o papel de carro-chefe dessa nova tecnologia de comunicação, disseminando o discurso da ditadura. Segundo Lima, o modelo de comunicação escolhido pelos militares tomava por base o modelo liberal das sociedades capitalistas. Nele, "a imprensa é um negócio privado independente, como qualquer outro, e o Estado controla as licenças e concessões de rádio e televisão”, porém, contrariamente ao princípio da "diversidade de conteúdo e da pluralidade de veículos implícitas na doutrina liberal, uma única rede - a Rede Globo - detém o virtual monopólio da televisão, consolidado e expandido durante os anos de regime autoritário" (ibidem,144).

Em 1965, as Organizações Globo, até então empresa proprietária de 0 Globo, jornal crítico a Jango e apoiador do golpe militar, inauguravam seu primeiro canal de TV no país. Curiosamente, naquela época, a empresa era investigada por uma Comissão Parlamentar de Inquérito ( $\mathrm{CPI}$ ) na Câmara dos Deputados, devido a acordo de cooperação técnica e financeira firmado pela Globo com o grupo norte-americano Time-Life, em 1962. Pela legislação brasileira, visando a proteção da soberania nacional, as concessões públicas dos meios de comunicação só podem ser dadas a empresas nacionais. Apesar disso, a CPI foi ignorada pelo governo militar, juntamente com as documentações e o parecer do Conselho Nacional de Telecomunicações que "comprovavam sobejamente o envolvimento ilegal do grupo brasileiro com seu congênere norte-americano" (ibidem, p.157). O caso contra a Globo seria fechado em 1968. 
Construídas as condições técnicas para a consolidação da televisão no país e definidos os aliados dessa empreitada, erigiu-se gigantesca estrutura de comunicação que, em pouquíssimo tempo, monopolizou o setor. Em 1968, a Globo contava com concessões públicas de televisão em São Paulo, Rio de Janeiro e Belo Horizonte; em 1972, chegava em Brasília e Recife, iniciando agressiva política comercial de afiliações que lhe permitiu atingir 36 emissoras no começo dos anos 1980. Em 1982, quando as eleições estaduais são retomadas no país - as presidenciais ocorreriam somente em 1989 - a empresa não era apenas a principal emissora brasileira, mas a quarta maior rede de televisão do mundo, cobrindo 3.505 dos 4.063 municípios existentes naquele momento, atingindo 93\% da população do país (ibidem, p.160).

Lima pondera que,

do ponto de vista econômico, foi indispensável o papel da Rede Globo na integração e um país de dimensões continentais, via integração de seu mercado consumidor. Do ponto de vista político, a programação da Rede Globo foi indispensável como portadora de uma mensagem nacional de otimismo desenvolvimentista, fundamental para dar sustentação e legitimação à hegemonia do autoritarismo (ibidem, p.161).

Entre 1960 e 1970, coube às empresas de comunicação que aderiram ao golpe criar e disseminar o "clima de euforia, possível pela construção de uma representação distorcida da vida no país que legitimava a estrutura socioeconômica à qual a própria Rede Globo estava incorporada" (ibidem, p. 169). Tarefa somada à presença de censores e interventores em postos-chave nas redações de jornais e semanários.

A disseminação do ufanismo em torno do "milagre brasileiro" durante a ditadura Médici é um bom exemplo da construção do "otimismo desenvolvimentista" naquele período. Com base em efetivo crescimento econômico, ocorrido entre 1969 e 1973 - "crescimento impulsionado por um modelo politicamente autoritário e economicamente excludente, capaz de beneficiar apenas 5\% da população brasileira", reitera Lima (ibidem, p.159) -, o discurso sobre o "milagre econômico" selou a adesão da classe média à ditadura, e aos seus valores, a partir de táticas pensadas e levadas à cabo por uma 
empresa moderna, ajustada à "política econômica excludente, concentradora e transnacionalizada" do regime militar (ibidem). O sucesso da empreitada foi e continua sendo indiscutível.

Inegável também foi a transformação que as Organizações Globo promoveram no ambiente cultural e comportamental do país no último meio século, inclusive, incorporando dramaturgos, roteiristas e artistas que fizeram parte da resistência cultural nos primeiros anos do golpe. Ao mesmo tempo, enquanto porta-voz de determinada concepção ideológica de mundo, mesmo após a ditadura civil-militar, a empresa assegurou a manutenção do pacto entre oligarquias econômicas nacionais e transnacionais, difundindo seus valores, e interferindo de modo nefasto, e antidemocrático, nos rumos políticos do país. Sem qualquer tipo de regulação pública, há mais de meio século, seu monopólio no setor de comunicação, com notória interferência na nossa vida política, expressa-se como um dos maiores entraves à consolidação da democracia no Brasil.

\section{- Cultura autoritária}

Em seu estudo sobre a cultura daquele período, Em busca do povo brasileiro: artistas da revolução, do CPC à Era da TV (Unesp, 2014), Marcelo Ridenti aponta que a censura embora não explícita na legislação, estava subentendida e "incluída numa abrangente defesa da moral e dos bons costumes, que atingia também o cinema", afirma o sociólogo:

Cerca de 430 livros foram censurados pela ditadura, 92 deles de autores nacionais, sendo 15 livros de não ficção, 11 peças teatrais publicadas em livro, além de dezenas de textos literários, em sua grande maioria (cerca de 60) eróticos ou pornográficos (Silva, 1989; Reimão, 2011,.p.31, 127). Esses números reiterariam que a censura se concentrou sobretudo nas obras tidas como ameaça à moral e aos bons costumes, o que nem sempre seria lembrado. Na música popular, por exemplo, ficou bem conhecida a perseguição da censura a Chico Buarque, considerado como inimigo político, cujas composições liberadas, entretanto, faziam sucesso comercial. Mas compositores populares ditos 'cafonas' -- como Odair José, Waldick Soriano, 
Benito de Paula, Luiz Ayrão e até mesmo Dom e Ravel, famosos pela composição de canções patrióticas usadas pelo regime sofreram com a censura, conforme mostrou Paulo César Araújo (2002). (Ridenti, 2014, p. 334).

A censura e a autocensura serão acompanhadas pelo advento da televisão, a tecnologia de comunicação de massas do momento, que permitiu a disseminação do discurso oficial do Estado, com muita desinformação e escancarada supressão dos fatos no noticiário - assassinatos eram divulgados como "troca de tiros", por exemplo -. O discurso oficial da Ditadura, disseminado pela televisão, encontrou território fértil no ideário da "família brasileira", reiterando os valores autoritários das relações hierarquizadas que se perpetuam, e se atualizam, desde os tempos coloniais. Prova disso foi escândalo de setores das classes média e alta do país contra a Lei das Domésticas, durante o governo Dilma, em 2015, garantindo o pagamento de horas extras e salário-mínimo, férias, fim de semana às trabalhadoras domésticas até então excluídas de direitos trabalhistas básicos ${ }^{14}$.

Em "Cultura Popular e autoritarismo" (2013), Marilena Chauí (professora emérita da Filosofia - USP) questiona "O que é a sociedade brasileira enquanto sociedade autoritária?", e responde:

É uma sociedade que conheceu a cidadania através de
uma figura inédita: o senhor-cidadão, e que conserva a
cidadania como privilégio de classe, fazendo-a ser uma
concessão regulada e periódica da classe dominante às
demais classes sociais, podendo ser-lhes retirada quando
os dominantes assim o decidem (como durante as
ditaduras). É uma sociedade na qual as diferenças e
assimetrias sociais e pessoais são imediatamente
transformadas em desigualdades, e estas, em relações de
hierarquias, mando e obediência (situação que vai da
família ao Estado, atravessa as instituições públicas e
privadas, permeia a cultura e as relações interpessoais).
Os indivíduos se distribuem imediatamente em superiores
e inferiores, ainda que alguém superior numa relação
possa tornar-se inferior em outra, dependo dos códigos de

${ }^{14}$ A Lei das Domésticas consiste na Emenda Constitucional $n^{\circ} 72$, de 2 de abril de 2013, e na Lei Complementar $\mathrm{n}^{\circ} 150$, de $1^{\circ}$ de junho de 2015. Informações em: < https://www.gov.br/esocial/pt-br/documentacao-tecnica/manuais/cartilha-trabalhadoresdomesticos-direitos-e-deveres > Acesso em 15 nov. 2020 
hierarquização que regem as relações sociais e pessoais. (Chauí, 2013, p.262)

Uma sociedade onde essas relações se efetuam "sob a forma de tutela e do favor (jamais do direito), e a legalidade se constitui como círculo fatal do arbítrio (dos dominantes) à transgressão (dos dominados) e, desta, ao arbítrio (dos dominantes)" (ibidem, p.257). Características que o golpe de 1964 não fundou, evidentemente, mas aprofundou de modo brutal, promovendo a "militarização da vida cotidiana" durante os 21 anos de ditadura militar e depois deles, quando se dá a transferência do

aparato militar-repressivo para o tratamento comum da população, em especial, trabalhadores do campo e da cidade (particularmente sindicalistas de oposição), desempregados, negros, menores infratores, presos comuns e delinquentes em geral (aí incluídos travestis e prostitutas) (ibidem:258).

A cotidiana e permanente reprodução da violência e controle do branco sobre o negro, do rico sobre o pobre, do homem sobre a mulher mantêm firmes o status quo que faz do Brasil, um dos países mais desiguais do mundo. No relatório Uma economia para os 99\% (2017), da Oxfam Internacional, ONG britânica que reúne 17 organizações e mais de 3 mil parceiros, com atuação em 100 países, a desigualdade social brasileira, fortalecida, como vimos, ao longo do período militar, chega em 2017 na seguinte proporção: os 6 bilionários mais ricos do país detêm a mesma riqueza que a metade mais pobre de nossa população, o equivalente a 100 milhões de pessoas ${ }^{15}$.

Daí a extrema atualidade dessas narrativas que dão corpo, voz e trama à militarização do cotidiano, às relações autoritárias e messiânicas; e sobretudo

\footnotetext{
15 Apenas a título de comparação, no mundo, 8 homens têm a mesma riqueza que as 3,6 bilhões de pessoas mais pobres do globo. Em termos de proporção mundial: o $1 \%$ mais rico da população detém uma riqueza maior que todos os $99 \%$ da população global juntos. Esses dados podem ser lidos em < https://www.oxfam.org.br/justica-social-e-economica/forum-economico-dedavos/uma-economia-para-os-99/ >
} 
ao sentimento de indignação, de revolta, de reação ante o discurso ufanista da ditadura militar.

\subsection{Discursos da Liberdade}

Passeata contra a guitarra elétrica. Parece piada, mas ela teve data e endereço: 17 de junho de 1967, na avenida Brigadeiro Luís Antônio, onde estudantes e artistas entoavam "abaixo a guitarra elétrica”, entre eles um constrangido Gilberto Gil, intimado por Elis Regina a encorpar o coro da esquerda. Esta é uma das várias histórias trazidas por Renato Terra e Ricardo Calil em Uma Noite em 1967, documentário sobre os principais acontecimentos e personagens da $3^{a}$. edição do Festival da Música Popular Brasileira, transmitido pela TV Record. A partir de fotos, vídeos e depoimentos dos que fizeram o Festival naquele ano, é possível observar três propostas estéticas e ideológicas que animavam o ambiente cultural de um país polarizado, após três anos de ditadura militar:

(1) Um primeiro grupo de artistas que compunham os quadros do programa Jovem Guarda, estreado em 1965 na mesma TV Record, com Roberto Carlos, Wanderleia e Erasmo Carlos no elenco. Focada em questões de foro íntimo e distante dos embates sociais e políticos, a Jovem Guarda apresentava à juventude brasileira, pela primeira vez "telespectadora", um estilo de vida alegre, colorido, ritmado, dançante, com asséptica rebeldia e tolerável sexualidade, em hits formatados pela indústria cultural, que estouravam nas rádios, inspirados no rock norte-americano e inglês dos anos 1950-60.

(2) Um segundo grupo de artistas que se filiavam à tradição da música popular brasileira (MPB), trazendo canções socialmente engajadas, as chamadas "canções de protesto", fortemente influenciadas pela poesia e literatura. São representantes desse grupo os jovens Chico Buarque, Nara Leão, Zé Kéti, Elis Regina, Jair Rodrigues, Sérgio Ricardo, Geraldo Vandré e tantos outros que abraçaram, naquele momento crucial, a missão civilizatória da arte. 
(3) Um terceiro grupo de artistas tropicalistas que comungavam dos princípios da Tropicália, movimento mais global, envolvendo diversas linguagens. Reivindicando a herança oswaldiana, esses artistas combinaram, em suas composições, o popular e o erudito, o subdesenvolvido e o desenvolvido, procurando suplantar as polarizações daquele momento e, sobretudo, questionar os códigos de comportamento do seu tempo. Caetano, Gil, Os Mutantes, os Novos Baianos não eram apenas cabeludos e fãs dos Beatles, como os artistas da Jovem Guarda, mas jovens andrógenos, e em termos comportamentais distantes do bom-mocismo da esquerda.

Além desses três grupos, os Festivais da Record enunciavam mais um ator: a plateia enquanto instância prevista nos embates permanentemente estimulados. Naquele mesmo Festival, Sergio Ricardo, conhecido compositor das músicas de protesto, não conseguiu interpretar "Beto Bom de Bola", devido a insistente vaia da plateia, taticamente deixada solta pelos produtores do programa televisivo, naquele contexto de redução progressiva da liberdade democráticas. Com apresentação de Blota Jr. e Sônia Ribeiro, o histórico III Festival de 1967 trazia Nara Leão e Sidney Miller ("A Estrada e o Violeiro"); Caetano Veloso ("Alegria, Alegria"); Gilberto Gil e Mutantes ("Domingo no Parque"); MPB-4 ("Gabriela"); Elis Regina e Dori Caymmi ("O Cantador"); Sérgio Ricardo ("Beto bom de bola"); Marilia Medalha e Edu Lobo ("Ponteio"); Nana Caymmi ("Bom Dia"), Geraldo Vandré ("Ventania"); Roberto Carlos ("Maria, Carnaval e Cinzas"); Chico Buarque ("Roda Viva") e Jair Rodrigues ("Samba de Maria").

\section{- Circuito do espetáculo}

A ebulição cultural, como sabemos, não se limita aos Festivais da Record, que são expressão midiática de um amplo movimento, captado por Roberto Schwarz (Letras - USP) no ensaio Cultura e Política: 1964-1969. No calor dos acontecimentos, ele questionava como essa efervescência foi possível em plena ditadura militar, mostrando o papel central do Partido Comunista Brasileiro (PCB) na disseminação do olhar crítico, da formação política, do discurso antiimperialista daquela geração. "A literatura anti-imperialista foi traduzida em 
grande escala e os jornais fervilhavam de comentários", destaca Schwarz (2008, p.71), apontando que o marxismo defendido pelo Partidão, entre os anos Vargas e Jango, teve um caráter muito mais anti-imperialista que anticapitalista, inclusive garantindo a aliança entre trabalhadores e burguesia industrial (nacional e progressista) contra as forças do setor agrário (retrógado e assumidamente pró-americano). Essa "deformação populista do marxismo", alfineta Schwarz, levou certo pensamento crítico especializado a insistir na "inviabilidade do capitalismo" e "não nos caminhos da revolução" (ibidem, p.78).

O florescimento desse pensamento de esquerda, explica Schwarz, devese a experiências que, durante os anos 1950 e 1960, procuraram conjugar arte e práxis na superação dos nossos atrasos sociais. E isso ocorre em meio à explosão da luta pela reforma agrária, das Ligas Camponesas, das agitações sindicais e, em particular, as do movimento estudantil, motivadas pelos debates sobre o marxismo que passam a fervilhar nas universidades. É quando ocorrem as experiências de alfabetização popular sob o método Paulo Freire, quando surge o Movimento Popular de Cultura (MPC) no Recife, que inspiraria os Centros Populares de Cultura (CPC), estreitando laços entre estudantes, trabalhadores e artistas.

É nesse momento, também, que surge o Cinema Novo levando às telas gigantes do cinema, as pessoas do povo, as contradições sociais, a hipocrisia das oligarquias, por meio de uma linguagem totalmente inovadora aos padrões da época, tornando-se referência mundial. Tempos de protagonismo também do teatro, capitaneado pelos CPCs, com forte espraiamento nos meios universitários. Nos anos anteriores ao golpe, o Brasil estava "irreconhecivelmente inteligente", observa Schwarz,

O jornalismo político dava um extraordinário salto nas grandes cidades, bem como o humorismo. Mesmo alguns deputados fizeram discursos com interesse. Em pequeno, era a produção intelectual que começava a reorientar a sua relação com as massas. Entretanto sobreveio o golpe e com ele a repressão e o silêncio das primeiras semanas (ibidem, p.82). 
É, portanto, contra essa inteligência em florescimento que se dará o contragolpe conservador no país, ancorado nos slogans do "combate à corrupção", da defesa da "família, tradição e propriedade", da eliminação e "morte ao comunismo", do "Brasil, ame-o ou deixe-o". Um movimento de afirmação dos valores arcaicos e tradicionais da cultura brasileira, segundo Schwarz, mais próximos à mentalidade do Brasil rural do que do Brasil urbano e cosmopolita. Um contragolpe propalado pelos que recusaram a oferta de modernização socializante da esquerda, optando pela modernização pró-norteamericana apresentada pelos militares, por meio da integração econômica, ideológica e militar com os Estados Unidos.

A efervescência dessa inteligência nacional, anterior ao golpe de 1964, consegue sobreviver até 1968, segundo Schwarz, devido à ditadura que, num primeiro momento (1964-1968), priorizou a repressão de lideranças populares que davam coesão aos movimentos de base na sociedade, como partidos, grêmios estudantis, sindicatos. Além da prisão de militares ou exílio de parlamentares que se recusaram a pactuar com o golpe.

Focado, portanto, em cortar o elo dessas lideranças junto às massas, o governo Castello Branco, que duraria até março de 1967, "não impediu a circulação teórica ou artística do ideário esquerdista, que embora em área restrita floresceu extraordinariamente" (2008, p.72). A repressão sobre a cultura e o pensamento crítico e de esquerda caberia a Costa e Silva, general linhadura, que reprimiu brutalmente a inteligência intelectual e cultural do país, promulgando o Al-5, em dezembro de 1968. É quando o Estado Militar se arvora detentor dos direitos sobre as liberdades coletivas e individuais, leia-se a prisão de qualquer cidadão que considerasse suspeito e ou inimigo do Estado ${ }^{16}$.

Outro aspecto salientado por Schwarz diz respeito ao papel do teatro naquele momento que, contrariamente à Literatura, oferecia "uma coleção de argumentos e comportamentos bem pensados para imitação, crítica ou rejeição",

\footnotetext{
${ }^{16}$ Inclusive bebês, crianças, adolescentes como revela o trabalho Infância Roubada - Crianças atingidas pela Ditadura Militar no Brasil, publicado em 2018, e organizado pela Comissão da Verdade do Estado de São Paulo "Rubens Paiva", e disponível em: < http://comissaodaverdade.al.sp.gov.br/livros/infancia-roubada/ > Acesso em 08 set 2020.
} 
em que "a distância entre o especialista e o leigo diminuíra muito" (Schwarz, 2008, p.97). Em um país com índices de 6,8\% de analfabetismo e $30 \%$ de analfabetismo funcional ${ }^{17}$, a Literatura nunca foi uma arte popular, e situação pior era a de 1970 , com $33,6 \%$ da população excluída da cultura escrita.

Esse "circuito do espetáculo" irá se transformar no "único reduto onde algum público poderia ser aglutinado, onde era possível um simulacro de militância" (2004, p. 38), afirma Heloisa Buarque de Hollanda (Literatura-UFRJ), em Impressões de Viagem: CPC, vanguarda e desbunde, 1960-1970. Como testemunhava Zé Celso, em 1979:

O que eu defendo no CPC é que, na sua disposição de mudar as coisas, ele tentou romper o gueto em que se encontrava o teatro. O teatro para mudar tem que sair de seu gueto, para ter uma outra dimensão. E o próprio fato dele sair do seu gueto, tomando contato com um outro Brasil, com as classes oprimidas, tudo isso há de provocar uma nova transa, mil relações (Corrêa, 1979, p.192).

Fora do gueto, a esquerda "festiva" integrará o circuito do espetáculo, apagando os limites entre "festa e subversão política". Como explica Hollanda, "o circuito do espetáculo concebia o público como fonte e razão da música se opondo ao tom grave e nobre dos CPCs" (ibidem, p.38). Neste circuito, além dos artistas, transitava o movimento estudantil da época - secundarista e universitário -, não apenas plateia dessas produções, mas, em momentos de grande violência, responsável pela segurança desses espetáculos, constantemente ameaçados pelo Estado e por grupos paramilitares como o Comando de Caça aos Comunistas (CCC).

\footnotetext{
${ }^{17}$ Em 2018, segundo dados do Indicador de Analfabetismo Funcional (INAF), 29\% da população ainda sofre as consequências do analfabetismo funcional, impossibilitadas de compreender textos simples; e somente $12 \%$ da população é proficiente - consegue compreender e elaborar textos complexos (INAF, 2018) - evidenciando o caráter elitista atribuído à Literatura no Brasil. O levantamento pode ser lido na íntegra em: < https://acaoeducativa.org.br/wpcontent/uploads/2018/08/Inaf2018_Relat\%C3\%B3rio-Resultados-Preliminares_v08Ago2018.pdf $>$ Último acesso em 11 nov. 2020.
} 
Criando estratégias de sobrevivência, com suporte do movimento estudantil, da resistência sindical e da igreja progressista, que possibilitavam a encenação dessa dramaturgia, seja sob corolário de Marx, de Cristo ou de Dioniso, esses artistas fizeram parte de uma geração memorável do teatro nacional, com Augusto Boal (Teatro do Oprimido); Zé Celso e Renato Borghi (Teatro Oficina); Cacilda Becker, Paulo Autran, Fernanda Montenegro (Teatro Brasileiro de Comédia - TBC); Oduvaldo Viana (Grupo União); Gianfrancesco Guarnieri (Teatro de Arena); e tantos outros.

Um dos grandes emblemas desse circuito do espetáculo é o show Opinião, cuja estreia em dezembro de 1964, contou com direção de Augusto Boal e elenco composto por Zé Keti, João do Vale e Nara Leão, depois substituída por Maria Bethânia, em pareceria do Teatro de Arena com os CPCs (UNE), na interconexão entre movimento cultural e estudantil. Nessas canções, aponta Hollanda, eram abordadas, sem subterfúgios, questões ligadas à vida cotidiana das pessoas, o universo do trabalho, a ausência de Estado, as desigualdades regionais e sociais; e, ao mesmo tempo, o universo mítico, literário, religioso, messiânico da cultura brasileira, em pequenas obras-primas como Carcará, Sina de Caboclo, Partido Alto, Opinião e tantas outras.

Como explica Evelina Hoisel em Supercaos (1980), nos primeiros momentos do golpe de 1964, a Literatura permaneceu na "antecena do palco cultural" (1980, p.22):

Cassada a difusão do texto escrito - do livro - numa sociedade que começa a incrementar os meios de divulgação de massa, em um contexto sociopolítico que, contrariamente ao clima de repressão, tende a transformar suas manifestações culturais e acontecimentos políticos em festas coletivas - as grandes passeatas do período exemplificam esta tendência à festa, à carnavalização dos acontecimentos políticos --, aos escritores caberia, talvez, assumir o desprestígio, a baixa e contemplar a festa. $O$ ato solitário da leitura não diz respeito aos espetáculos coletivos. Mas, apesar de tudo, muitos arriscam (Hoisel, 1980, p.26).

Ela identifica duas atitudes no período. A primeira é a recusa à festa: 
Os textos que dizem desta atitude tematizam problemas de cunho mais universal - Clarice Lispector - ou de natureza regionalista - Cândido de Carvalho, O coronel e o lobisomem; Mário Palmério, Chapadão do Bugre; Adonias Filho, o Forte; Autran Dourado, Ópera dos mortos. Nesses textos a situação política e cultural pós-64 se encontra suspensa ou recalcada (ibidem)

A segunda é a participação na festa, que Hoisel traduz como o questionamento "estatuto do signo verbal e da qualidade do discursivo inerente ao literário. A saída proposta é a fusão e a contaminação do signo verbal com outros sistemas semiológicos (ibidem). É o que vemos, por exemplo, em PanAmérica que "participa da festa sem recusar o livro", promovendo uma "exacerbação do trânsito entre o signo verbal (que se apaga cada vez mais) e outros signos", afinal, em meio à revolução da linguagem, "o processo é tudo: pintura, escultura, literatura. Em suma, um grande happening" (ibidem, p.26-27).

\section{- Antropofagia tropicalista}

Misturando guitarra e pandeiro, o entretenimento e o protesto, recusando as desigualdades, mas abraçando, sem reticências, a modernidade acenada pela indústria cultural norte-americana, os tropicalistas procuraram questionar as polarizações do período, apropriando-se da antropofagia oswaldiana. Durante os ensaios de O Rei da Vela, em 1967¹8, Zé Celso escreveu emblemático manifesto, dizia ele:

hoje que a cultura internacional se volta para o sentido da arte como linguagem, como leitura da realidade através das próprias expressões de superestrutura que a sociedade espontaneamente cria, sem mediação do intelectual (história em quadrinhos, por exemplo); a arte nacional pode subdesenvolvidamente também, se quiser, e pelo óbvio, redescobrir Oswald. Sua peça está surpreendentemente dentro da estética mais moderna do teatro e da arte visual. A superteatralidade, a superação mesmo do racionalismo

\footnotetext{
18 A peça entraria em cartaz novamente em 2018, pelo mesmo Teatro Oficina de Zé Celso, em releitura não menos política da conjuntura política e cultural do país, evidenciando a força da literatura de Oswald, a universalidade de sua peça e a permanência das estruturas de opressão no país.
} 
brechtiano através de uma arte teatral síntese de todas as artes e não-artes, circo, show, teatro de revista etc. (Corrêa, 1967, p.1)

Sob a benção da antropofagia, espraiam-se para vários domínios artísticas essa superteatralidade, a obra-síntese e "de tudo" devoradora, sob o signo da "liberdade de criação", dispondo, combinando, articulando "várias opções de teatralizar" essas "possibilidades". Arte que abrange "o mau gosto", o ridículo, o cafona, naquele momento, a "única forma de expressar o surrealismo brasileiro", avalia Zé Celso (ibidem, p.3).

Em Tropicália, alegoria, alegria (1996), Celso Favaretto (Filosofia-USP) elenca várias propostas estéticas do movimento, como: (1) O deslocamento da crítica social para a observação e descrição dos modos de construção da obra: "a tendência cool das canções tropicalistas trata o social sem o pathos então vigente" (Favaretto, 2007, p.21); (2) A combinação (por adição ou justaposição) dos aspectos arcaicos da sociedade brasileira (herança colonial) com os da cultura universal e globalizada; (3) A conjugação dos opostos, em busca de uma totalidade capaz de abranger o sério, o grave, o histórico, o sagrado e, também, o engraçado (cafona, kitsch, a parodia), o banal, o cotidiano, o profano; (4) A integração do profano ambiente industrial ao sagrado mundo das artes, modus operandi dos artistas pop, uma das principais influências da Tropicália.

Surgido na década de 1950, o pop teve maior ascendência a partir dos anos 1960, na Inglaterra e nos Estados Unidos; e introduziu no universo sagrado das artes, os produtos da indústria consumidos pelas massas. Abreviação de Pop Art (Arte Popular), o termo pop foi cunhado pelo crítico norte-americano Leslie Fiedler e pelo arquiteto inglês Peter Reyner Banham, e surge em 1955, no artigo Veículos do Desejo de Banham sobre como o cinema de Hollywood vinha inspirando o design dos automóveis, transformando-os de simples objetos de uso em verdadeiros objetos de desejo.

Escrito na década de 1950, quando os países desenvolvidos investiram na construção da massa consumidora, elevando a renda das classes média e trabalhadora (Cf. Dowbor, 1994), o artigo observa, justamente, a transformação da ordem industrial, mostrando as correlações entre indústria automobilística e 
indústria cultural na comercialização de desejos (estilos de vida, identidades, status social). Banham inclusive critica a resistência dos intelectuais de seu tempo, orientados pela ideia de "permanência, durabilidade e perenidade", em compreender o novo mundo que surgia diante de seus olhos: um mundo mais e mais preenchido de objetos e de relações de consumo descartáveis (Banham, 2011, online).

Um ano depois, o Independent Group, composto por artistas ligados a Banham, promovia a exposição This is Tomorrow na Whitechapel Art Gallery (Londres), que trazia com o quatro de Richard Hamilton, consagrado professor do Royal College of Art, e intitulado:

Figura 5 - Just what is it that makes today's homes so different, so appealing? (Hamilton, 1956)

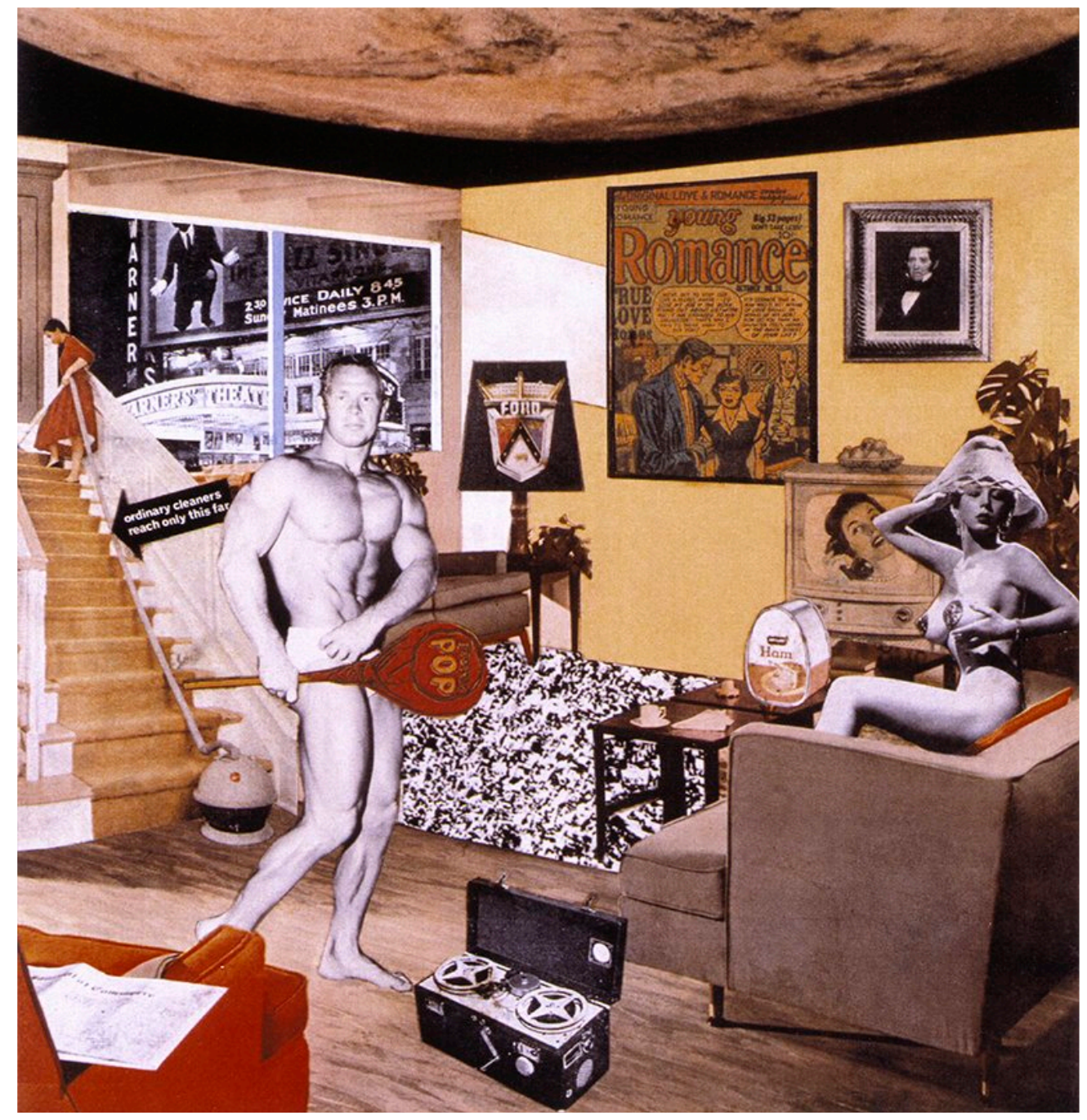

Fonte: Hamilton, 1956, online 
Primeira obra pop em uma galeria de arte, Just what is it that makes today's homes so different, so appealing? é uma colagem de diferentes objetos de consumo, apresentados em distintas linguagens (fotografia, desenho, cartoon), no interior de uma sala de estar. Eletrodomésticos e objetos vários, mídias de comunicação (jornais, revistas, televisão, gravador) e culturais (cinema, quadrinhos), slogans publicitários e índices históricos (corrida espacial representada pela Lua no teto) preenchem o território dos supostos moradores que, por sua vez, são personagens-ícones de revistas - a pi-nup e o halterofilista Charles Atlas -seminus e empunhando objetos de evidente conotação sexual: 0 peito e o pirulito gigante, em divertida menção fálica, enunciando a estreia do movimento na inscrição "POP".

Hamilton justapõe elementos do cotidiano da classe média dos países industrializados - os novos objetos que, agora, fazem parte do cenário doméstico -- respondendo o questionamento-título da obra. Do culto ao corpo a produtos de massa, a colagem identifica a mudança na mentalidade da sociedade capitalista do pós-Guerra. Como destaca o poeta Mello e Castro, a arte pop

cola elementos efetivamente bons e em uso na própria sociedade em que vive. E usa-os e cola-os de modo a exagerar os sítios onde eles realmente estão e as utilidades que têm. Desse modo, essas colagens de tão óbvias tornam-se incomodas e denunciam a vacuidade $e$ a inutilidade profunda de suas posições e dos seus usos na sociedade. As colagens pop são espelhos cujas imagens revelam a redundância estrutural de uma sociedade de excessos e de vazios - a americana". (Castro, 1993: 45)

Além dessa crítica "à vacuidade da cultura de consumo" que passa a ser hegemônica no mundo Ocidental e chega ao Brasil, durante a ditadura civilmilitar; o pop também ridiculariza a arte enquanto símbolo de status, apresentando-a como mais um entre os produtos de consumo no capitalismo. Andy Warhol, consagrada liderança do movimento, apontava o pop como um "novo jeito de olhar o presente", destacando que, enquanto os artistas pop se deslumbravam com os outdoors e os personagens do mass media, a maior parte 
da sociedade norte-americana vivia essas mesmas mudanças presa às referências sociais e culturais do passado. O pop, nesse sentido, "vinha de fora para dentro" (Warhol, 2013, p.54-55) para exprimir as transformações de uma sociedade que se via, após a II Guerra, diante de um cotidiano drasticamente transformado pelo capitalismo produtivo e industrial.

Sensíveis às transformações da cultura de massas, fãs de Marilyn Monroe e Che Guevara, os tropicalistas irão desnudar os paradoxos desse Brasil profundo, em um processo de complexificação das vanguardas. Longe de se instituir como corrente artística, organizada ou fechada em si mesma, a Tropicália é a expressão do movimento de uma vanguarda em meio a um contexto brutal em termos políticos, e se compõe de amplo leque de artistas gravitando em seu entorno, em graus distintos de adesão, mas em diálogo com as ideias tropicalistas, e em diversas linguagens, como explica Zé Celso:

A gente sacou que havia uma identidade muito grande entre nós, mas não era uma influência de um para o outro, nem um movimento programado. Era toda uma confluência de ansiedades, fruto das recusas e dos movimentos sociais que se ensaiavam (Corrêa, 1979, p.198).

"Confluência de ansiedades" de artistas que passaram a se frequentar, a viver e a experimentar processos de trocas permanentes. Nesse momento, a antiga discussão sobre a originalidade da cultura brasileira será confrontada pelo debate sobre a indústria cultural, transferindo o enfoque dos aspectos étnicos para os aspectos políticos, sociais e econômicos, evocando o conflito latente entre o local e o universal. O "fundo técnico" da antropofagia é exatamente os valores da sociedade industrial, expressos pela justaposição entre o arcaico e moderno, revelando as "indeterminações históricas", os "recalques sociais", o "sincretismo cultural" que desembocarão em "cena fantasmagórica toda feita de cacos" (ibidem, p.58-9).

Como aponta Favaretto, em sua recusa das polarizações, o Tropicalismo não apresentará nenhum "projeto definido de superação" - como já observa Schwarz em 1969 --, mas vai expor o conflito de interpretações. Além disso, "as 
indeterminações do Brasil, no nível da história e das linguagens passaram a ser reinterpretadas à luz dos mitos da cultura urbana e industrial (2007, p.56).

Com a Tropicália, explica Hollanda, surgiu no Brasil uma "nova linguagem crítica" guiada pela "subversão de valores e padrões de comportamento". Longe de discutir se a revolução seria "socialista-proletária" ou "nacional-popular ou burguesa", o Tropicalismo colocou em questão a própria "ideia de tomada de poder", do autoritarismo e da burocratização, anunciando a crise de perspectivas. Recusando o "futuro prometido como redentor", esses artistas optaram pelo "aqui e agora", pela necessidade de revolucionar o corpo e o comportamento, rompendo com o "tom grave e a falta de flexibilidade da prática política vigente" (Hollanda, 2004, p.70-72). Em sua avaliação, embora dialogassem de modo nada pacífico com os ideários dos CPCs, as vanguardas mantiveram a crença nos "aspectos revolucionários da palavra poética".

Surgida em meados anos 1950, com os irmãos Campos, Haroldo e Augusto, e Décio Pignatari à frente, a Poesia Concreta, ancorada na racionalidade, técnica, precisão, acenava para a utopia desenvolvimentista que via o subdesenvolvimento como etapa a ser superada, disseminando nos circuitos culturais do período a releitura de autores como Ezra Pound, E. Cummings, James Joyce, Mallarmé; em suma, trazendo a discussão experimental para o centro da criação artística, aponta Hollanda. Ela cita, também, os adeptos do Poema-práxis - Mario Chamie à frente - que tematizaram as contradições da nossa realidade social, recusando a tradição literária discursiva e as subjetividades do autor, e expressando as contradições dos modos e relações de produção. A palavra para esses autores almejava a encarnação do real para que o poema pudesse ser elemento de transformação. Já o Poema-processo de Moacy Cirne, Wladimir Dias-Pino, Álvaro de Sá, radicalizava sugestões visuais e não discursivas do concretismo, buscando o choque do receptor e se utilizando do happening, também absorvido pela militância da esquerda política naquele momento.

Publicado em 1967, o romance de Agrippino surge em meio a essa efervescência política e cultural. É contemporâneo a todas essas experimentações, em um momento de valorização dessas linguagens. Para que 
possamos localizá-lo entre as literaturas do seu tempo, recorreremos à cronologia dos principais acontecimentos políticos e culturais no Brasil entre 1958 e 1984, trazidos por Ridenti. Em sua seleção sobre a produção de 1967, além de PanAmérica, ele destaca Quarup de Antonio Callado; Pessach, a travessia, de Carlos Heitor Cony (que prefaciaria Lugar Comum, primeiro livro de Agrippino); O prisioneiro de Érico Veríssimo; e Ópera dos mortos de Autran Dourado. Enquanto isso, Zé Celso encenaria O Rei da Vela no Teatro Oficina; a dupla Augusto Boal e Gianfrancesco Guarnieri, Arena conta Tiradentes; e Plínio Marcos, quatro peças em um só ano: Navalha na carne, Dois Perdidos numa Noite Suja, Homens de papel e Quando as máquinas param (Ridenti, 2014, p. 360-61).

Essa ebulição será interrompida com o Al-5, em dezembro de 1968, quando ocorre verdadeira cruzada contra a inteligência crítica e artística do país.

\section{- A Marginália}

Até então reunidos em torno do grupo da Tropicália, muitos artistas passaram a constituir a Marginália. Como explica Hollanda, cunhada no slogan "Seja marginal, seja herói", obra de Hélio Oiticica, a cultura marginal se situa entre 1968 até meados da década de 1970. Nela, a radicalidade formal irá se transformar em violenta resistência estética. Novos temas são introduzidos: o cotidiano social e urbano, a violência, o sexo, as drogas, o pop regado pela contracultura, movimentos hippie, underground. A partir da Marginália, o "tema da liberdade, da desrepressão, da procura de 'autenticidade' ganha fôlego substituindo os temas diretamente políticos". As vanguardas, até então identificadas com "o povo" ou "o proletariado" trazem novos personagens à cena revolucionária - "os negros, homossexuais, freaks, marginal de morro, pivete, Madame Satã, cultos afro-brasileiros e escola de samba" (Hollanda, 2004, p. 77).

Entre os artistas da Marginália, Hollanda destaca Waly Salomão, Torquato Neto, Francisco Alvim, Gramiro de Matos, Chacal; na música, Jards Macalé, Sérgio Sampaio, Jorge Mautner, Luiz Melodia, Carlos Pinto e Lanny Gordin; no cinema, Ozualdo Candeias, Rogério Sganzerla, Neville de Almeida, André 
Tonacci, Júlio Bressane, Eliseu Visconti, Álvaro Guimarães, entre outros. Muitos deles atuantes na imprensa alternativa no país (O Pasquim, Flor do Mal, A Pomba e Bondinho), garantindo a sobrevivência das discussões culturais no período. Em O Pasquim, Luiz Carlos Maciel mantinha a coluna Underground. No Última Hora, Torquato Neto mantinha sua "Geleia Geral"; e Waly Salomão, no Correio da Manhã, a "Super frente super-oito". Torquato e Waly organizariam, ainda, a coletânea Navilouca (1974), reunindo a produção daquele período em um único e histórico exemplar.

Radicalizando questões relativas ao comportamento, esses artistas da contracultura abordaram temas até então proibidos para a literatura, como drogas, homossexualidade e bissexualidade, práticas sexuais as mais diversas deslocando, segundo Hollanda, o binômio arte/sociedade para o binômio arte/vida, no qual a fragmentação não mais significava "recolher partes do real" enquanto procedimento literário, mas sim exprimir as "sensações mais imediatas" enquanto "sentimento de mundo" (ibidem, p. 90-1).

Zero é lançado em meio a esses movimentos, e dialoga diretamente com o espírito dessa contracultura. Quando a obra foi lançada no país, em 1975, conforme seleção de Ridenti, eram publicados os seguintes romances: Dentro da noite veloz (poemas de 1962 a 1974) de Ferreira Gullar, o romance Os que bebem como os cães, de Assis Brasil; Pilatos de Carlos Heitor Cony; Confissões de Ralfo de Sérgio Sant'Anna; Lavoura Arcaica de Raduan Nassar; Os sinos da Agonia de Autran Dourado; Caminhos dos gerais (contos) de Bernardo Élis; O ovo apunhalado (contos) de Caio Fernando Abreu; e Feliz ano novo (contos) de Rubem Fonseca (apreendido pela censura). Naquele mesmo ano, Bibi Ferreira estreava Gota d'Água, de Paulo Pontes e Chico Buarque.

Três anos depois, em 1978, era lançado Riverão Sussuarana de Glauber Rocha que aparece, na seleção de Ridenti, ao lado de O labirinto de Jorge Andrade; Maíra de Darcy Ribeiro; e Lúcio Flávio, o passageiro da agonia de José Louzeiro. Naquele ano, Antunes Filho estreava Macunaíma nos palcos; e Chico Buarque, Ópera do Malandro. E a novela de Gilberto Braga, Dancin'days, estourava os números de audiência da Rede Globo, influenciando 
comportamentos de Norte a Sul do país, entre julho de 1978 a janeiro de 1979 (ibidem, p.348).

Ao longo deste primeiro capítulo, nós procuramos observar como a crítica anti-imperialista e o questionamento das relações de poder foram pensados pela cultura brasileira, em particular, pela resistência engajada da esquerda e pelos artistas da Tropicália e da Marginália. Uma das características marcantes dessas obras é o fato delas articularem, em termos de plano de conteúdo, temas e figuras de sua contemporaneidade, inserindo os discursos da opressão e os da liberdade daqueles que sustentaram ou que repudiaram 1964, o que nos permite acompanhar como a oposição semântica opressão vs. liberdade, estruturadora das relações sociais na sociedade brasileira, e desde os tempos coloniais, foi potencializada durante os 21 anos de ditadura.

Por meio do terror de Estado, do acirramento das desigualdades sociais e regionais, da disseminação do discurso ufanista sobre o real, reiterando o caráter autoritário das relações sociais e trabalhistas no país. Pudemos ver, também, como o discurso oficial da ditadura foi trabalhado na cultura sob a forma do pastiche, do humor ácido, da ridicularização do opressor, observando vários movimentos e propostas literárias que aceitaram o desafio histórico de seu tempo, participando da "festa", ou seja, procurando outros modos de sensibilização do enunciatário.

Vale ainda destacar que tanto Glauber Rocha quanto Agrippino de Paula e Loyola Brandão participaram ativamente dessa movimentação cultural. Aliás, com exceção (talvez) de Glauber, que teve seu romance praticamente ignorado pela crítica e pelo público, PanAmérica e Zero tiveram imensa importância na trajetória desses autores. Visto, portanto, o contexto histórico e cultural dos discursos que irão compor o plano de conteúdo dessas obras, fortemente referenciais, vejamos, a partir de agora, o fenômeno experimental propriamente dito, observando-o sob o prisma das vanguardas e neovanguardas do século $\mathrm{XX}$. 


\section{Sair do Gueto}

Em O Prazer do Texto, Roland Barthes define dois tipos possíveis de textos: os de prazer e os de fruição. Os primeiros promovem o conforto no leitor, garantindo a continuidade da narrativa, sem grandes subversões durante $o$ ato de leitura. Os segundos, pelo contrário, levam ao "estado de perda" e de "estremecimento da relação entre leitor e linguagem" (Barthes, 2008, p.62). Quando falamos em literatura experimental é exatamente sobre esse segundo grupo de narrativas ao qual nos referimos.

A eficácia dessa definição, que será esmiuçada adiante, reside na possibilidade de atestá-la a partir do impacto gerado pelas narrativas experimentais, por exemplo, quando, ao longo da obra predominante verbal de Memórias Póstumas de Brás Cubas, relato póstumo de um defunto, nós nos deparamos com a lápide da jovem Eulália, inscrita na linguagem verbal:

\section{CAPÍTULO CXXV / EPITÁFIO}

AQUI JAZ

D. EULÁLIA DAMASCENA DE BRITO

MORTA

AOS DEZENOVE ANOS DE IDADE

ORAI POR ELA!

(Assis, Memórias Póstumas, p. 319)

Ao desenhar, a partir dos recursos da linguagem verbal, uma lápide em seu texto, Machado de Assis levanta vários questionamentos. Por que a lápide foi colocada dessa forma, nesse e não em outro momento da narrativa? O que 
a fusão entre as linguagens verbal e visual tem a dizer em termos estéticos? Aliás, como a narrativa permite essa fusão sem prejuízo à lógica interna da obra? Quase um século depois, o mesmo procedimento seria utilizado por Ignácio de Loyola Brandão em Zero:

\section{Obedeça à sinalização e viaje tranquilo. ${ }^{1}$}

José e Rosa estão viajando para o interior, para que José peça a mão de sua noiva. Segundo normas estabelecidas de nossa sociedade.

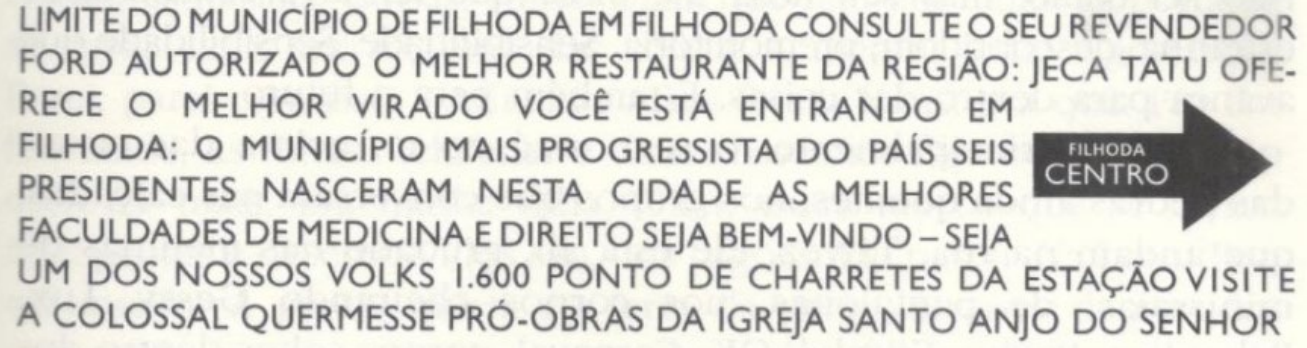

(Zero, p.171)

Ao contrário da narrativa machadiana, Zero é uma obra sincrética, construída por meio de fragmentos, tal como um mosaico, no qual se encaixa a unidade cênica acima, conferindo espacialidade à estrada percorrida pelos protagonistas José e Rosa. Nota-se, visualmente, a linguagem verbal transformada em estrada a partir do que pode ser lido nas placas e letreiros durante o percurso de viagem do casal.

Essas experimentações na linguagem verbal, utilizadas por determinadas obras experimentais, contrastam com narrativas tradicionais como Lucíola de José Alencar, compatriota de Machado; ou Dois Irmãos, de Milton Hatoum, contemporâneo a Brandão. Alencar e Hatoum costumam priorizar em suas narrativas a continuidade da leitura; enquanto Machado e Brandão, nas obras acima citadas, promovem descontinuidades, implodindo a linearidade e, com isso, abalando o conforto (e a passividade) do leitor durante o ato de leitura.

O que se dá em ambos os casos é a intensificação do procedimento de singularização dos objetos, definido por Chklovsky como procedimento próprio 
da arte e que consiste em "obscurecer a forma, aumentar a dificuldade e a duração da percepção", orientada pelo objetivo de promover um "choque no receptor" (Chklovsky, 1976, p.50). Daí o estranhamento imediato ante uma literatura facilmente percebida, mas raramente conceituada, como experimental.

Mas, o que seria literatura experimental?

Segundo o Houaiss, experimentalismo é tudo aquilo que "se pauta na experiência, no conhecimento prático; empírico: método experimental”, inclui "pesquisa ou método científico", "prioriza o conhecimento adquirido através da prática, da observação, de estudos concretos; em que há experimentação". No âmbito das artes, o Dicionário de Arte Moderna e Contemporânea da Universidade de Oxford define experimental como prática artística que explora novas técnicas e/ou novas tecnologias, apontando a ambivalência "moral" do termo: elogioso aos adeptos do empirismo na arte; pejorativo aos que o concebem como arte inacabada ou mal realizada (Oxford, 2015, online).

A pergunta novamente se impõe: o que significa "empirismo" ou "investigação experimental" na arte literária? Qual o discurso de quem faz e pensa a arte de vanguarda?

\subsection{A busca pela transgressão}

Em 2017, durante o lançamento da obra Ernesto na Torre de Babe/19, no departamento de Letras da Universidade de São Paulo (USP), o poeta Ernesto de Melo e Castro, aos 86 anos, ensinava-nos o que significa a atitude de vanguarda ao alertar sobre a imperiosa necessidade de os artistas hoje estarem atentos não somente ao presente, mas ao futuro acenado pelas recentes descobertas da Ciência. Um dos pioneiros da poesia visual em Portugal, autor de 25 livros de poesia experimental, Melo e Castro, falecido em 2020, foi também um pensador da prática experimental, com 18 ensaios de crítica e teoria literária,

19 O livro conta com 18 poemas do autor traduzidos para o inglês, francês, holandês, japonês e grego clássico. 
orientados pela privilegiada visão de quem pratica o experimentalismo e sobre ele reflete.

Grande parte desses ensaios foram publicados em $O$ fim visual do século XX. Suas análises, entre 1960 e 1970, quase que exclusivamente, debruçam-se sobre poesia experimental; e a partir dos 1980, Melo e Castro agrega a prosa em suas análises. No artigo "Ficção Portuguesa após 25 de abril de 1974" 20, ensaio de 1984, ele não apenas define o trabalho experimental como estabelece a unidade entre o agir do prosador e do poeta:

O modo de inovação típico da vanguarda é o trabalho na linguagem e na escrita, pois esse trabalho implica necessariamente a transformação dos conteúdos ideológicos. Em outras palavras, na escrita da ficção ou na escrita da poesia, os elementos sobre os quais o escritor pode trabalhar são precisamente as palavras e as suas leis de associação ou de construção de frases significativas, a morfologia e a sintaxe. Ao reinventar, ou redescobrir, ou transgredir essas leis, o escritor produz novos significados. É esta a maneira própria de agir do prosador e do poeta para produzir prosa de ficção e poesia (Castro, 1993, p.144, grifos nossos).

A partir dessas premissas, pode-se apreender no que consiste o trabalho experimental ou trabalho de vanguarda: "transformar conteúdos ideológicos", trabalhando "as palavras e leis de associação ou de construção de frases, morfologia e sintaxe" visando "reinventar, redescobrir, transgredir leis" no sentido de gerar novos significados. Melo e Castro também define o "escritor poeta", unindo ambas as palavras em um só termo, como "um transformador emocional do discurso e um descobridor de outras formas de comunicação" (ibidem, p. 144).

Em "Proposições Básicas e seu Desenvolvimento Combinatório", publicado originalmente em 1965, não contente em definir a prática experimental, ele a encena durante o processo de definição, unindo a prática artística e o discurso crítico por meio da combinatória de cinco palavras - poesia,

2025 de abril de 1974 marca a data da Revolução dos Cravos, quando a democracia foi restaurada no país após 41 anos de ditadura do Estado Novo (salazarismo). 
poético, poema, experiência, experimental -, extraindo delas nove maneiras distintas de se pensar criticamente o ato criador e três métodos de estudo do poema. Entre essas combinatórias, Melo e Castro define princípios fundamentais da arte de vanguarda,

arte que, sem necessariamente acreditar na possibilidade de evolução e de progresso no que diz respeito à qualidade estética dos objetos criados pelo homem, acredita muito mais, e faz disso o seu ponto de partida, na necessidade que o homem tem de proceder a um atualizar constante dos meios de realização do ato criador, de modo que a sua natural atividade estética se desenvolva no mesmo nível de modulação existencial que os outros atos de sua vida, principalmente os que melhor caracterizam o coeficiente de antecipação do tempo no estado atual da sua vida social e econômica e dos recursos científicos (ibidem, p.26, grifos nossos).

Artista experimental, Mello e Castro rompe com dois sensos comuns em torno da atividade criadora: a ideia de evolução na arte e a sacralização da figura do artista.

Ao colocar em xeque a noção de evolução e progresso históricos da qualidade estética, o poeta-crítico afasta alguns equívocos, por exemplo, a ideia de que a arte rupestre é "pior" do que a medieval que, por sua vez, é "pior" do que a contemporânea e assim por diante. Afastando a concepção evolutiva em termos estéticos, o poeta acena o que importa à vanguarda: "a atualização constante dos meios de realização do ato criador" (ibidem).

Necessidade que atravessa o tempo. A arte experimental não surgiu com as vanguardas do século $\mathrm{XX}$, tampouco é fruto da contemporaneidade, como muitos afirmam de forma equivocada. Há 2.300 anos, pelo menos, o poeta grego Símias de Rodes já compunha poemas visuais, como se pode notar abaixo, no poema: 


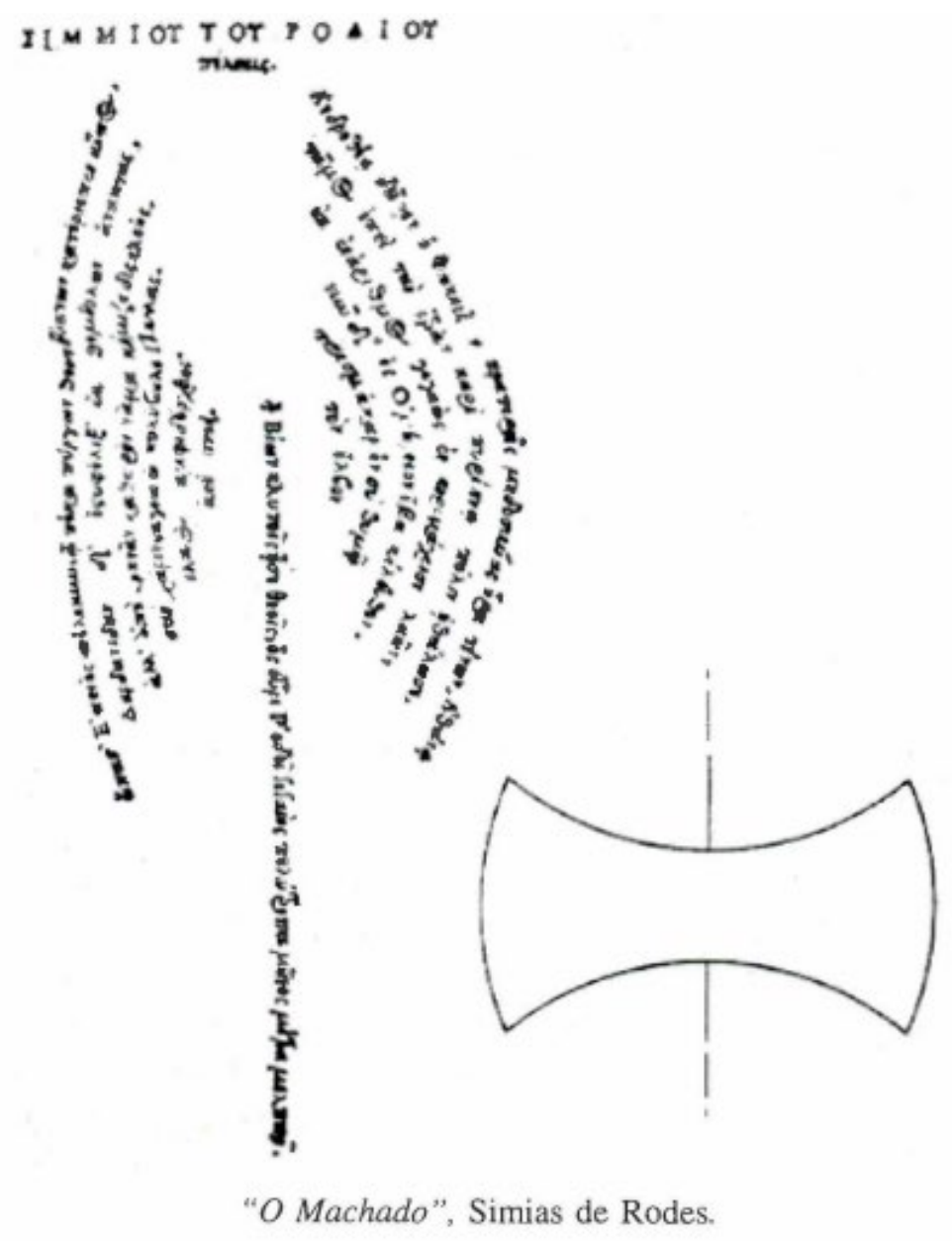

(Xavier, 2002, p. 165-7)

No caso de "O Ovo", conforme tradução abaixo de José Paulo Paes, para além de seu formato ovalóide, a leitura do poema exige que ele seja percorrido, durante a leitura, também em sentido circular: o primeiro verso deve ser sucedido pela leitura do último; o segundo pelo penúltimo e assim por diante até o $20^{\circ}$ verso: 


\title{
O Ovo
}

\author{
Acolhe \\ da fêmea canora \\ este novo urdume que, animosa \\ Tirando-o de sob as asas maternas, o rvidoso \\ e mandou que, de metro de um só pé, crescesse em número \\ e seguiu de pronto, desde cima, o declive dos pés erradios \\ tão rápido, nisso, quanto as pernas velozes dos fillhotes de gamo \\ e faz vencer, impetuosos, as colinas no rastro da sua nutriz querida, \\ até que, de dentro do seu covil, uma fera cruel, ao eco do balido, pule \\ mãe, e lhes saia célere no encalço pelos montes boscosos recobertos de neve. \\ Assim também o renomado deus instiga os pés rápidos da canção a ritmos complexos. \\ do chão de pedra pronta a pegar alguma das crias descuidosas da mosqueada \\ balindo por montes de rico pasto e grutas de ninfas de fino tornozelo \\ que imortal desejo impele, precipites, para a ansiada teta da mãe \\ para bater, atrás deles, a vánia e concorde ária das Piérides \\ até 0 auge de dez pés, respeitando a boa ordem dos ritmos, \\ arauto dos deuses, Hermes, jogou-a à tribo dos mortais, \\ e pura, ela compós na dor estridula do parto. \\ do rouxinol dórico \\ benévolo. \\ "O Ovo", 325 a.C., Símias de Rodes, tradução uireta uo gregu por \\ José Paulo Paes.
}

(Xavier, 2002. p.165-7)

Narrativas experimentais podem ser encontradas em várias outras obras ao longo do período alexandrino, da renascença carolíngia, do barroco e, notadamente, do século $X X$, derrubando outro equívoco em torno da literatura experimental: a ideia de que se trata de movimento artístico ou de escola literária. Assim fosse, seria um movimento de, no mínimo, mais de 2.300 anos.

Procedimento do fazer artístico, a arte experimental não se fixa em vanguardas, movimentos ou escolas literárias, mas os perpassa, impulsionando novos meios de investigação estética. Daí a contribuição da perspectiva sincrônica sobre as formas resultantes dessa "atualização constante dos meios 
de realização do ato criador" (Castro, 1993, p.26), estabelecendo o diálogo entre as várias propostas artísticas ou escrituras que permite, por exemplo, aproximar a poesia concretista brasileira e os poemas de Símias de Rodes; os mamutes pintados em Lascaux e os tubarões do artista britânico Damien Hirst; e assim por diante.

Em sua concepção de arte de vanguarda, Melo e Castro menciona, com sensibilidade, a necessidade de desenvolvimento da atividade estética "no mesmo nível de modulação que outras atividades da vida", ou seja, a partir de uma perspectiva dessacralizada da atividade criadora e, ao mesmo tempo, sacralizante da vida e de suas atividades cotidianas essenciais. Dá, assim, outra conotação, mais natural, a um dos lugares-comuns em torno da atividade criadora: a correspondência entre vida e arte.

Outra concepção trazida pelo poeta sobre a literatura experimental diz respeito à centralidade do estudo e da investigação na composição da obra de arte. Neste mesmo artigo, em que realiza várias combinatórias, ele define a Poesia Experimental como "forma específica de atividade criadora do homem com o objetivo de fazer experiências sobre esse fenômeno ou ato, estudando o resultado dessas experiências" (idem: 25). A assertiva é desdobrada em:

\footnotetext{
Poesia que se preocupa com as bases e a evolução do ato poético e do poema como objeto. O estudo do resultado das experiências realizadas é fundamental. Neste estudo reside, de fato, o valor de projeção do ato criador experimental. Por ele a poesia experimental é sinônimo de arte de vanguarda (ibidem).
}

Valorado enquanto via de acesso à arte, o estudo é parte constitutiva do processo criativo. Melo e Castro concebe a criação experimental como resultado de duplo processo de investigação: sobre o objeto criado e sobre o próprio processo e evolução do ato criador. É a partir dessa "investigação e pesquisa do próprio ato livre de criar" que resulta a liberdade do artista, agora, desdobrado em criador-crítico: 
O criador tem apenas como pré-munição uma atitude de investigação e pesquisa do seu próprio ato livre de criar. A criação é feita livremente, estando o seu processo desde o início sob autovigilância do poeta, que assim tem de proceder a um desdobramento criador-crítico" (ibidem, $p$. 28).

Nota-se a ênfase na responsabilidade do criador-crítico em relação à própria obra. Melo e Castro chega a qualificar os que não possuem essa autoconsciência de poetas da retaguarda, "pois a sua atitude passiva e irracional impede a força projetiva da poesia de se objetivar em termos de tempo futuro" (idem: 29).

Nesse caminho refletido a partir da prática experimental e projetado enquanto ideal criador, ele também aborda a relação entre ética e estética. $O$ tema é trabalhado no artigo "Excurso A - A Poesia Experimental", em que aponta que não é a estética que servirá à moral, mas a moral que servirá a estética, porque para o artista de vanguarda "a prática experimental livre é norma ética de conduta basilar para o prosseguimento aberto e funcional da estética" (idem:35).

O compromisso é, portanto, com a liberdade criadora. A questão ideológica também é abordada em suas reflexões, e apresentada como a própria visão de mundo do poeta-escritor que se encontra implícita (queira ele ou não) em sua obra. Não se trata de enxertar ideologias, a liberdade de criação é premissa básica; mas de tornar o criador da obra (o homem) consciente da sua própria realidade. Ele, inclusive, define a atitude experimental como:

(...) uma atitude mental de investigação e de procura, de sincronismo vital do artista, não já com o tempo, mas sim com os meios, métodos e problemas que a sociedade e a ciência dispõem e propõem como tipicamente seus perante a invasão inevitável do futuro (ibidem, p.34, grifos nossos).

A relação entre escritor/poeta e realidade é total: dá-se a partir de um sincronismo vital e, uma vez criada, a obra de arte isola-se de seu autor e se coloca "em uma perspectiva de disseminação coletiva de informação" (ibidem: 35). Não se trata apenas de estar "antenado com seu tempo", mas sincronizado 
com os "meios, métodos e problemas" da sociedade. Essa conexão com o real, aponta Melo e Castro, longe de um compromisso moral, é condição essencial ao aprofundamento do

(...) estudo da possibilidade ou impossibilidade de comunicação entre os homens através dos vários sistemas de sinalização dirigidos especificamente às portas da percepção. A obra de arte necessita, pois, ter existência objetiva estruturada nesses sistemas de sinalização. O autor, entidade psicológica, fica necessariamente fora do circuito (ibidem, grifos nossos).

O estudo experimental incide, portanto, sobre as possibilidades de comunicação entre os homens e os "sistemas de sinalização" sobre os quais se assenta a obra de arte e dos quais depende sua existência objetiva e estruturada. O poeta português descarta a figura do autor, anunciando sua inutilidade, à semelhança de Roland Barthes que, em "A Morte do Autor", afirma: "é a linguagem que fala, não o autor" na medida em que "escrever é, através de uma impessoalidade prévia (...), atingir esse ponto em que só a linguagem age 'performa' e não 'eu'" (Barthes, 2004, p.59). Morto o autor, o olhar do crítico se debruça sobre a relação entre obra e leitor:

A obra de arte experimental requer, pois, uma mudança de atitude do seu fruidor de passiva para ativa. Assim estabelece-se uma troca de energia entre obra e fruidor, sendo o tipo dessa energia dependente do princípio estrutural em que a obra assenta e da porta da percepção do fruidor que ela é capaz de impressionar. (Melo e Castro, 1993, p. 35, grifos nossos).

A passagem de uma atitude passiva à uma atitude ativa é objetivo de, pelo menos, todas as obras experimentais analisadas neste estudo. Em Riverão Sussuarana, por exemplo, ao seguir viagem com Glauber Rocha e Guimarães Rosa pelo Sertão brasileiro, abre-se a trilha de uma narrativa fortemente transtextual. Cabe ao leitor reconstruir, com seu repertório prévio, o percurso 
aberto por essas referências (citações várias, episódios históricos etc.) e índices de transtextualidade.

Convocado a preencher as lacunas da narrativa, em processo de escritura conjunta, o leitor assume a co-enunciação que, nas obras experimentais, é condição para sua fruição.

De forma geral, a partir das contribuições de Melo e Castro, pode-se definir narrativas experimentais ou de vanguarda como aquelas que:

a) Dialogam com outras obras (em perspectiva sincrônica), com seu contexto (a partir de "sincronia vital" entre autor e mundo) e com as projeções do futuro (o que prospecta a Ciência);

b) São construídas a partir do trabalho de investigação e manejo de sistemas de sinalização que permitem a comunicação entre os homens, orientadas pela ideia de reinvenção, redescoberta e transgressão;

c) Dependem da autoconsciência do criador-crítico: a ele cabe estudar e analisar a evolução do seu processo criador e o resultado das experiências do ato criativo (obra).

d) Transformam conteúdos ideológicos e geram novos sentidos, promovendo uma transformação na relação leitor/obra, levando a uma postura mais ativa e menos passiva durante o ato de leitura.

A narrativa experimental se situa, a partir dessas contribuições, como uma literatura que expressa a autoconsciência crítica e criadora, a partir do manejo inovador de técnicas diversas, orientadas pelo desejo de proximidade e ampliação dos espaços de colaboração do leitor.

Naturalmente, em suas reflexões, Melo e Castro expressa uma determinada concepção de vanguarda que guarda influências, como se verá adiante, das premissas levantadas por artistas de vanguarda do começo do século $X X$.

Da mesma forma, o pensamento de vanguarda de seu tempo encontra eco nas propostas estéticas atuais. Apenas a título de exemplo, no intuito de marcar 
continuidades e rupturas, vejamos uma recente defesa da arte de vanguarda, surgida nesta parte Sul do continente latino-americano.

\section{- Comunidade Inoperante}

Em 2004, reagindo à ausência de inovação na literatura argentina, o escritor e tradutor Damián Tabarovsky publicou Literatura à Esquerda, levantando questões importantes sobre escritura e o papel do autor, relações de poder que orientam o que deve ou não ser lido, mercado e academia; e a definição do que seria uma "literatura de esquerda".

Ao contrário do que sugere o título, literatura de esquerda não se refere a engajamento partidário, propriamente dito - embora, notadamente, a provocação nos remeta ao espectro das ideias progressistas e libertárias que compõem a esquerda política stricto sensu -, mas diz respeito à literatura que "suspeita de toda convenção, inclusive as próprias", que "não busca inaugurar novo paradigma, mas pôr em xeque a própria ideia de paradigma" e "de ordem literária", seja ela qual for (Tabarovsky, 2017, p.16). Uma literatura que se coloca contrária à ordem estabelecida e que precisa lidar com a atração de dois polos principais: o mercado e a academia, dos quais Tabarovsky recomenda, na medida do possível, a mais completa distância.

Segundo o escritor argentino, a literatura de esquerda seria escrita por um "escritor sem público", "que escreve para ninguém", "em nome de ninguém", "sem outra rede além do desejo louco de novidade" - portanto, guiada pela mesma necessidade de atualização contínua salientada por Melo e Castro. Caberia a esse autor estudar a linguagem, escolhendo "a própria trama para narrar a sua decomposição para pôr o sentido em suspenso" e "a própria linguagem, para perfurá-la" em busca desse "lado de fora - o fora da linguagem - que nunca chega" (ibidem, p.16). Uma concepção de vanguarda que também aponta como central a ação crítica e criadora e o conhecimento da linguagem verbal. 
Ciente das relações de poder (academia e mercado não são as únicas citadas, mas apresentadas como polos), essa literatura de esquerda se opõe à literatura convencional que Tabarovsky define como "literatura café com leite", em geral, "romances 'bem escritos', 'inteligentes', com insípidas gotas de experimentação, sem que por isso deixem de ser 'emocionantes', 'arrebatadores' e 'profundos'”, ironiza. Ele dá nomes: Milan Kundera, Paul Auster, José Saramago, Antonio Tabucchi, Jonathan Franzen entre outros autores de "romances belos, agradáveis" que "não incomodam ninguém", apenas fazem com que "o escritor se contente em ser um mero 'publicador de livros"” (ibidem, p.79).

Para Tabarovsky, o avanço dessa literatura "café com leite" reflete o avanço do "discurso conservador, dos valores mais convencionais, das ideias mais gastas, das estratégias mais calculadas, dos riscos menos tomados" (idem:26), culminando em uma arte bonita que apenas agrada, mas não incomoda. Em oposição a ela, o escritor argentino propõe uma literatura inscrita em um espaço invisível - fora dos circuitos da academia e do mercado -, em "outro mundo", "o mundo do mergulho da linguagem", salientando que "por estar instalada na pura negatividade, a visibilidade é seu atributo ausente" (idem: 18). Em síntese: a "invisibilidade" é condição para a liberdade do processo criativo.

Tabarovsky dialoga com premissas de artistas que, como Melo e Castro, atuaram em movimentos de vanguarda: investigação da linguagem, subversão à normas, liberdade criativa e de criação, denúncia do "beletrismo", oposição às forças que delimitam o que é ou não publicado. Sua proposta, porém, difere-se de outras na medida em torna eufóricos os valores da invisibilidade e inexistência de um coletivo, ou melhor, a existência de uma "comunidade inoperante" composta pelos que não pertencem a comunidade alguma.

Nenhuma fala universal representa sua voz, mas "ela expressa a fala da multiplicidade de solitudes" (ibidem, p.22); propondo o inacabamento enquanto "trânsito ininterrupto das rupturas singulares". Cada escritor inauguraria, assim, a sua própria comunidade. Não escola ou movimento, ele "não funda nada, não implica nenhum estabelecimento, não administra nenhum intercâmbio, nenhuma história da comunidade se engendra aí" (ibidem, p.20). Somente assim, defende 
o escritor argentino, a literatura poderá ultrapassar a lógica da vanguarda: doando "sua própria inoperância, sua incapacidade de converter-se em mercadoria (como produz mercado) e sua resistência a transformar-se em obra (como supõe a academia)" (ibidem, p.20).

Em contextos distintos, Melo e Castro e Tabarovsky trazem uma concepção de literatura que valoriza a liberdade criadora (e cada um enfrenta os cerceamentos de seu contexto histórico), defendendo o "mergulho na linguagem", o estudo e a experimentação formal. Colocam em destaque inquietações estéticas próprias do exercício experimental, inclusive, seu movimento: o deslocamento contínuo promovido por transgressões que ao se tornarem regras sofrem novo deslocamento, impulsionadas por um movimento contínuo de criação e reflexão crítica sobre obras e o exercício literário. Daí a importância da discussão que realizam, cientes que da prática e da crítica sobre a prática depende a vitalidade da literatura.

Uma vez levantadas essas duas concepções da literatura de vanguarda por escritores-críticos, necessário faz-se compreendê-la à luz da semiótica, em especial, das contribuições de Roland Barthes.

\subsection{A fruição experimental}

Em Teoria da Literatura: uma introdução, o crítico literário britânico Terry Eagleton recomenda a qualquer nova teoria sobre a literatura a seguinte questão: "como ela se comportaria em relação ao Finnegans Wake, de Joyce?" (Eagleton, 2006, p.126). Calcadas na transgressão de regras, as obras experimentais - das quais Joyce, sem dúvidas, é autor exemplar - situam-se na fronteira de enquadramentos teóricos. A contribuição dessas obras às teorias do discurso e à semiótica é notável; da mesma forma, o conhecimento semiótico contribui enormemente à compreensão das especificidades das produções experimentais.

Como explica Pietroforte, em O Discurso da Poesia Concreta, o sentido se forma na linguagem, a partir da relação entre os signos estabelecida durante 
os processos discursivos. Uma vez formado, esse sentido "se projeta sobre 'as coisas' construindo visões de mundo, geradas nas línguas e nos demais sistemas de significação" sejam eles verbais, não verbais ou sincréticos (Pietroforte, 1996, p.15). Mobilizada pela busca de atualização contínua, a literatura experimental tende ao sincretismo, transpondo técnicas utilizadas por outros sistemas semiológicos para a linguagem verbal. Constelação de variadas escrituras, ela é composta por vários tipos de transtextualidade intertextualidade (alusões, citações, plagiatos), paratextualidade (título, advertências, notas, prefácios etc.), metatextualidade (diversas formas de comentários), arquitextualidade (designações genéricas não necessariamente expressas), hipertextualidade (texto que se enxerta num texto anterior, por transformação ou imitação) (Maingueneau, 1996, p. 27) - que operam vários campos discursivos (discursos antagônicos ou semelhantes).

Dada a heterogeneidade com a qual se expressa, é impossível definir a literatura experimental a partir desta ou daquela subversão. Ela se situa no âmbito de procedimentos que visam a contínua atualização e expansão de possibilidades expressivas. Daí a contribuição da semiologia barthesiana que, longe de impor regras, propõe conceitos que permitem observar a direção desses experimentalismos.

\section{- Textos de Prazer e de Fruição}

Em O Rumor da Língua (2004), reunião de ensaios publicados entre 1970 e 1980, Barthes esclarece que analisar uma obra literária não significa decifrála, mas desfiá-la "como uma malha de meia que escapa". É impossível esgotar uma escritura (embora seja possível deslindá-la) porque ela "propõe sentido sem parar, mas sempre para evaporá-lo" procedendo "uma isenção sistemática do sentido" (Barthes, 2004, p.63). Dado o caráter polifônico e a multiplicidade de campos discursivos acionados pelas obras experimentais, nem se pretendesse, a presente análise conseguiria esgotar essas obras, o que não impede a compreensão da lógica dessas narrativas, vislumbrando algumas das várias camadas de sentido colocadas em movimento pelo jogo enunciativo. 
Outro esclarecimento de Barthes diz respeito à falácia que seria medir a escritura por seus atributos, "declarando-a 'rica', 'sóbria', 'pobre', 'curiosa' etc.", na medida em que a escritura é indiferente "às conveniências dos gêneros, dos temas, dos fins" e ao "drapeado das belas obras", podendo ser "inteiramente paródica e zombar das divisões e das hierarquias" (ibidem, 2005, p. 37). Uma falácia que, embora se acredite superada, vem sustentando o desinteresse, tanto da academia quanto do mercado, em relação às obras experimentais, evidenciando, em ambos os espaços, a dificuldade de se apreender o valor estético de obras que fogem dos padrões normativos do romance convencional; e a tendência de se avaliar, a partir das mesmas categorias de valor, obras tradicionais e obras experimentais.

Diferenciá-las, portanto, faz-se necessário. Nesse sentido, Barthes traz uma contribuição fundamental ao propor a existência de dois tipos de textos:

Texto de prazer: "aquele que contenta, enche, dá euforia; aquele que vem da cultura, não rompe com ela, está ligado a uma prática confortável de leitura" (Barthes 2008:21). Um exemplo de texto de prazer pode ser visto abaixo. Tratase do primeiro parágrafo de Um Crime Delicado de Sérgio Santana, Prêmio Jabuti de Melhor Romance, em 1998:

\footnotetext{
É preciso esclarecer que, na primeira vez em que a vi, ela estava sentada à mesa do Café e eu não podia observá-la de corpo inteiro, embora concluísse, por seu rosto de traços finos e delicados - e pelos seios pouco salientes, assim à primeira vista, dentro de uma blusa graciosa -, que era uma mulher magra, com corpo bem-proporcionado. Mas foi principalmente o rosto que me atraiu, os cabelos claros, encaracolados, o que me fez pensar, talvez ajudado por duas doses de conhaque, numa princesa russa. (Santana, 1997:9)
}

Embora Um Crime Delicado realize interessante inovação, fornecendo de antemão respostas a possíveis lacunas da trama e não o contrário, conforme o esperando em narrativa policial; sua estrutura obedece o padrão de uma literatura convencional: linearidade, descrição, narrador e personagens bem marcados, priorizando a continuidade e a prática confortável da leitura. 
Textos de gozo ou fruição: "texto que põe em estado de perda, aquele que desconforta (talvez dê até um enfado), faz vacilar as bases históricas, culturais, psicológicas do leitor, a consistência de seus gostos, de seus valores e de suas lembranças, faz entrar em crise sua relação com a linguagem" (Barthes 2008, p.21). Abaixo, como exemplo de texto de fruição, segue o primeiro parágrafo de Riverão Sussuarana de Glauber Rocha:

$11050 \begin{aligned} & \text { Ybrahym Sued \& Jacyntho de } \\ & \text { Thormes falavam do escritor di- } \\ & \text { plomata João Guimarães Rosa }\end{aligned}$ myneyro publicado pela Editôra JOSÉ OLYMPIO de grandes autores brazyleyros como José Lins do Rego, Graciliano Ramos, Carlos Drumond de Andrade: "SAGARANA", “CORPO DE BAILE", "GRANDE SERTĀO: VEREDAS" na juscelinismoída Bahya Era diretor do "Suplemento Letras? Artes do Dyaryo de Notycyas" e escrevi na coluna "Quarto Mundo", terceira pagina, artigo Joyce lembrando superioridade Villa Lôbos - Bach/ Beethoven/ /Wagner/Strawinsky \& Portynary - Delacroix/Goya/Gaughin/ Picasso... recebo meses depois no Jornal o livro "PRIMEIRAS ESTORIAS" dedicaligrafado em forma

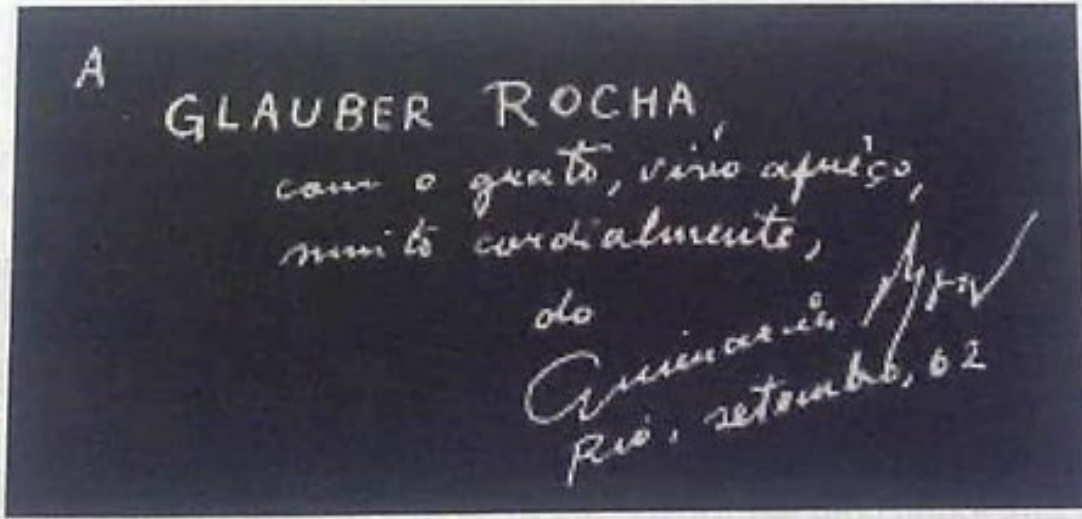

e pedi minha

amiga Dale pra encardenar o volume, surpreso pelo fato do Mestre Brazyleyro de Letras, conhecendapenas um artigo do conquystense que falava bem mas lera mal sua obra, expressar grande sinceradmiração.

(Riverão, p.9)

Nota-se acima radical subversão da narrativa linear, em linguagem essencialmente sincrética (com direito à bilhete de Rosa), índices de transtextualidade, operando sucessivas descontinuidades durante a leitura, 
entre outros aspectos que serão aprofundados em capítulo destinado à análise das obras experimentais contemporâneas.

Diante de narrativas tão diferentes, como se pode pretender adotar os mesmos critérios de valor para analisá-las ou estabelecer juízos de valor, como faz a crítica atual? Como explica Pietroforte, em O Discurso da Poesia Concreta (2011),

(...) cada poeta, além do estilo com que procura se definir em relação aos demais escritores com os quais dialoga, atua em determinados regimes de fazer poético, regimes estes relacionados com a prática da linguagem e sua concepção enquanto forma para construir poesia. Desse ponto de vista, preterir um poeta a outro depende do regime poético adotado; é no regime poético que o poeta se dá a conhecer e a ser avaliado por seus leitores e críticos. Em outras palavras, cada regime pede um critério de análise baseado em seus princípios particulares; é em relação a esses princípios e seus fundamentos que um poema pode ser considerado bom ou ruim (Pietroforte, 2011.p.15).

No caso do romance, da mesma forma, preterir uma narrativa a outra dependerá do regime poético adotado por essas narrativas. Obras experimentais e não experimentais demandam abordagens distintas, evitando equívocos, por exemplo, o de caracterizar o experimental como arte mal-acabada ou outros absurdos semelhantes. Importante frisar que mesmo entre obras experimentais, vários regimes são mobilizados. Uma obra pode, por exemplo, promover subversões radicais no plano de expressão e manter-se conservadora em termos de revestimento figurativo e vice-versa. A predominância de determinadas transgressões, porém, indica o regime poético ao qual ela pertence, daí a necessidade de uma tipologia da literatura experimental, evidenciando esses regimes para evitar generalizações que só tendem a depreciar a arte experimental.

Além disso, é preciso esclarecer que tanto os textos de prazer quanto os de fruição possuem igualmente valor literário, considerando que "cada obra, cada gênero define sua identidade por sua maneira de gerar a transtextualidade 
e é sobre esse trabalho diferenciador que convêm centrar a atenção" (Maingueneau, 1996, p. 27). Não se trata de realizar a crítica às avessas, mas de registrar as várias possibilidades de expressão da arte literária, exaltando sua pluralidade e o amplo espectro de expectativas que ela é capaz de atender. Embora textos de fruição não se limitem a textos experimentais, é seguro afirmar que a escritura experimental tende a se manifestar enquanto texto de fruição operando o estremecimento na relação entre leitor e linguagem e mobilizando novas formas de experimentação estética da linguagem verbal.

\section{- Discursos Encrático e Acrático}

Transformar o mundo pela linguagem. Essa premissa, inscrita nas escrituras experimentais que se engajaram na "festa" revolucionária durante a ditadura civil-militar, na teoria barthesiana, encontra uma conceituação mais precisa. Conforme explica a professora Leyla Perrone-Moisés, do Departamento de Letras da Universidade de São Paulo (USP), "a grande inimiga de Barthes é sempre a Doxa ou opinião pública, o Espírito majoritário, o Consenso pequeno burguês, a Voz do Natural, a Violência do Preconceito" (Barthes, 2013, p.63).

Barthes demonstra que essa luta contra a doxa é travada, cotidianamente, no âmbito da própria linguagem. Toda "linguagem é uma legislação [e] a língua o seu código. Não vemos o poder que reside na língua, porque esquecemos que toda língua é uma classificação, e que toda classificação é opressiva" (ibidem, p.13). Para o teórico, "transformar o mundo é transformar a linguagem, combater suas escleroses e resistir a seus acomodamentos" (ibidem, p. 63).

Destacando que as forças da liberdade que residem na literatura não dependem da pessoa (do autor) mas do "trabalho de deslocamento que ele exerce sobre a língua" (idem, p.18), Barthes sentencia:

se chamamos de liberdade não só a potência de se subtrair ao poder, mas também e sobretudo a de não submeter ninguém, não pode então haver liberdade se não fora da linguagem. Infelizmente, a linguagem humana é sem exterior: é um lugar fechado (Barthes, 2013, p. 16). 
Apoiado na negatividade de sua comunidade inoperante, a proposta de Tabarovsky ecoa a consciência dessa prisão, a qual todos estamos condenados, ao mencionar o desejo impossível de alcançar esse "fora da linguagem", revelando a atualidade do pensamento barthesiano. Em "Círculo Aberto, Ritmo Liberto" (1969), o poeta Melo e Castro traz um vislumbre desse desejo impossível, o "fora da linguagem" barthesiano nos planos de conteúdo e de expressão do poema abaixo:

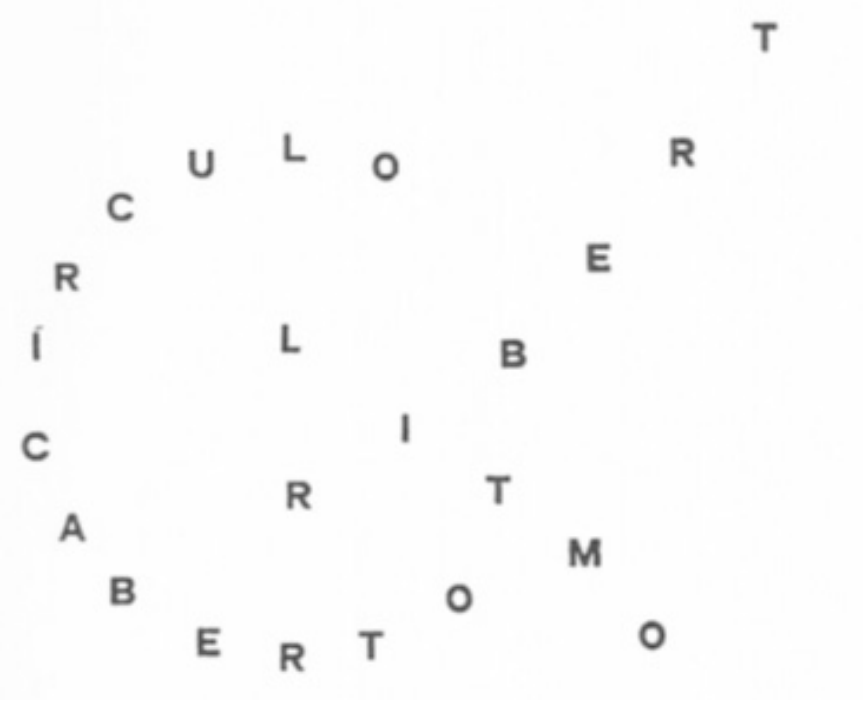

(Melo e Castro, 2016, p.98)

Essa utópica "materialidade", o desejo de "encarnação do real", resultante da correspondência entre os planos de expressão e conteúdo, conforme observamos acima, será buscada pelos romances experimentais, e manifestada em vários de seus fragmentos. É assim, por exemplo, que a escritura em PanAmérica se aproximará de uma lente cinematográfica, como veremos adiante. No movimento pendular dessa utopia, as escrituras experimentais afirmam sua liberdade criadora e crítica, em processo de construção de identidade a partir do diálogo com a tradição (o Outro), e que consiste, em última instância, na reação ante à impossibilidade de se subtrair as relações de poder no interior da linguagem, onde os signos se relacionam e o sentido é criado. 
Essa ação de liberdade se trata, segundo Barthes, de uma trapaça somente possível pela literatura:

\begin{abstract}
Essa trapaça salutar, essa esquiva, esse logro magnífico que permite ouvir a língua fora do poder, no esplendor de uma revolução permanente da linguagem, eu a chamo, quanto a mim: literatura. (Barthes, 2013, p. 17, grifos nossos).
\end{abstract}

Em "Guerra das Linguagens" (2004), ele detalha o que significa essa trapaça, considerando que somente a escritura tem o poder de reunir todas as "falas sérias". Somente ela

(...) pode frustrar qualquer regra retórica, qualquer lei de gênero, qualquer arrogância de sistema: a escritura é atópica; com relação à guerra das linguagens, que não suprime, mas desloca, ela antecipa um estado das práticas de leitura e de escrita, no qual é o desejo que circula, não a dominação. (Barthes, 2004, p. 138).

Esse deslocamento ante a guerra das linguagens, explica Barthes, consiste em deslocar a dominação pelo desejo, por meio da antecipação do estado das práticas de leitura e de escrita permitindo, por exemplo, o contato entre as linguagens encrática (do poder) e acrática (fora do poder). Dá-se, assim, a tentativa de transformação do mundo por meio da escritura.

Para Barthes, é encrático todo discurso que, submisso aos códigos da doxa, enuncia "as linhas estruturantes da ideologia desse discurso". O discurso encrático não cede lugar a outros discursos, explica, daí "a sensação de sufocamento, de pegajosidade que pode provocar naqueles que não participam dele". Plenamente ideológico, esse discurso "apresenta o real como a inversão da ideologia", enquanto linguagem "não marcada", produzindo uma "intimidação amaciada" (Barthes, 2004, p.128-9). Um exemplo notório disso é o discurso do chamado "mercado", disseminado como não-ideológico ou expressão "natural" da realidade. 
O discurso acrático, por sua vez, enuncia-se contra a doxa, em diversos graus. Daí ele ser sempre um discurso paradoxal: "são todas as linguagens que se elaboram fora da doxa e são por isso mesmo recusadas por ela", é o discurso do pesquisador, do escritor, do intelectual, por exemplo. De forma geral, as narrativas experimentais tendem a se enunciar como discursos acráticos na medida em que se posicionam, de antemão, contra as convenções do fazer literário (concepções em torno do narrador, personagens, encadeamento da trama etc.). No caso específico das obras analisadas neste estudo, acresce intensa crítica ao discurso do poder do seu contexto histórico, sobretudo Zero que ecoa, de modo contundente, a várias opressões durante a ditadura militar.

Barthes aponta, também, que um mesmo discurso pode, dependendo do contexto em que se encontra, passar de acrático para encrático e vice e versa. O caso da literatura experimental é exemplar: o cânone literário brasileiro é composto por obras acráticas e experimentais, porém, ao se tornarem cânone, essas obras assumem a posição encrática, criando paradigmas de composição artística. Talvez aí resida a dificuldade, reiteramos, em muitos círculos acadêmicos, de se compreender Grande Sertão: Veredas como obra experimental e ao mesmo tempo "alta literatura".

\section{- Texto e obra}

Uma terceira contribuição que permite a compreensão da narrativa experimental, em particular a impossibilidade de seu esgotamento, é a definição barthesiana de obra e de Texto. Segundo Barthes, a obra é um "organismo que cresce por expansão vital", um "fragmento de substância" que "ocupa alguma porção do espaço dos livros", aquilo que se vê e se pode apanhar com as mãos (ibidem, 2004, p. 72). O Texto, por sua vez, é um

(...) campo metodológico que se vê como obra, mas é demonstrado e dito segundo certas regras (ou contra certas regras), aquilo que se mantém na linguagem e só existe tomado num discurso, provado em um trabalho, em uma produção. O Texto seria uma "rede", "combinatória" e "sistemática". Neste sentido, ele não é uma decomposição 
da obra, mas a obra é que a "cauda imaginária do Texto". (ibidem, 2004, p. 72).

Ao contrário da obra (que pode ser Texto), o Texto não pode ser apanhado em hierarquias ou divisão de gêneros. Ele transcende essas definições e sempre "suscita problemas de classificação (essa é uma de suas funções 'sociais')", "sempre implica certa experiência do limite", "é sempre paradoxal" porque, ao contrário das obras, o Texto não se fecha sobre o significado funcionando como um signo. O seu campo, explica Barthes, é do significante, entendido não como "vestíbulo material" ou "primeira parte do sentido", mas o "depois do sentido" que gera mais e mais significantes. O Texto é, dessa forma, um sistema sem fim, nem centro; um significante perpétuo, entretexto de outro texto (Barthes, 2004: 74-5).

Considerando as narrativas experimentais é possível identificar problemas de classificação, a experiência do "limite", a geração de significantes, concebendo-as no interior dessa "cauda imaginária" que compõem o Texto, essa tessitura composta de outras obras. A definição de Barthes, no entanto, permite pensarmos no próprio experimentalismo e na atitude experimental (Cf. Melo e Castro, 1993) como instrumento de composição desse Texto, pela geração contínua de significantes que torna essas obras impossíveis de serem classificadas. Pode-se afirmar, portanto, que obras experimentais tendem a ser Texto.

Com base nesses três conceitos barthesianos - texto de fruição e de prazer, obra e Texto e discurso encrático e acrático -, é possível situar as narrativas experimentais como:

- Textos de fruição que visam desestabilizar as relações entre leitor e linguagem;

- Textos que não apenas colocam em relevo a guerra da linguagem (discurso acrático vs. discurso encrático), mas tendem a assumir o 
discurso acrático no plano de conteúdo e/ou no plano de expressão;

- Obras que tendem a compor a tessitura desse grande Texto paradoxal, contribuindo, por meio do sincretismo e da transtextualidade em que se expressam, com o processo contínuo de geração de significantes.

\subsection{Tradição \& experimento}

Ao longo do século $\mathrm{XX}$, a prática experimental foi intensificada em dois momentos principais: nas vanguardas artísticas (avant-garde), entre 1910 e 1920, quando surgiram várias propostas estéticas (cubismo, futurismo, dadaísmo, expressionismo, surrealismo etc.) que enunciaram a arte enquanto construção estética; e as vanguardas do pós-Guerra que, para fins de diferenciação entre ambas, chamaremos de neovanguardas, acompanhando a terminologia utilizada pelo historiador e crítico de arte norte-americano Hal Foster, em O retorno do real (2017). Frente ao engessamento desse primeiro momento vanguardista, incorporado à instituição arte, as neovanguardas impulsionaram novo fôlego à experimentação, retomando e ampliando seus procedimentos experimentais.

De forma geral, todas as obras analisadas no presente estudo partem e/ou dialogam com experimentações realizadas nesses dois períodos, daí a necessidade de compreendermos suas principais motivações.

\section{- Tradição Moderna}

Em Os Filhos do Barro (1974) o poeta e crítico literário Octávio Paz se debruça sobre as vanguardas e neovanguardas, elaborando o conceito de "tradição moderna": a tradição composta de contínuas rupturas, sendo que cada 
ruptura representa novo começo na arte. Em sua avaliação, a Modernidade tem início na poesia do Romantismo inglês e alemão do século XIX; e seu término, justamente, no momento de seu ápice: durante as vanguardas no começo do século XX. "Como não constatar que essas sucessões de rupturas são também uma continuidade?", questiona Paz, ao afirmar que

\begin{abstract}
a Modernidade é uma tradição polêmica que desaloja a tradição imperante, seja ela qual for; mas só a desaloja para, no instante seguinte, ceder lugar a outra tradição que, por sua vez, é mais uma manifestação momentânea da atualidade. A Modernidade nunca é ela mesma: é sempre outra (Paz, 2013, p.15).
\end{abstract}

Segundo essa concepção, a Modernidade é um espaço de disputa, de diálogo ou consenso entre escrituras plurais e heterogêneas, que reafirmam a tradição moderna a cada deslocamento promovido por novas propostas estéticas. O Modernismo brasileiro seria um exemplo desse movimento de deslocamentos, cujas disputas eram, inclusive, travadas nos jornais da época.

Em 18 de março de 1924, o Correio da Manhã divulgava o Manifesto da Poesia Pau-Brasil que, entre várias outras assertivas, propunha:

A síntese

O equilíbrio

O acabamento de carrosserie

A invenção

A surpresa

Uma nova perspectiva

(Andrade, 1924, online)

A discussão posta em cena por Oswald se ancora em aspectos constitutivos da linguagem literária. Há uma proposta clara - síntese, equilíbrio, invenção, surpresa - que se afirma como nova perspectiva em oposição à tradição de seu tempo.

Entre as várias inovações trazidas pela Modernidade, Paz destaca a predominância da razão-crítica: "os autores de vanguarda amam e criticam o seu 
objeto e a própria Modernidade (...) realizam, assim, a contínua destruição criadora" (ibidem:21) por meio de obras profundamente autocríticas e críticas da própria Modernidade. O surgimento dessa razão crítica, segundo o teórico, está umbilicalmente relacionado à emergência do tempo histórico na Civilização Ocidental, em oposição a duas concepções de tempo: a cíclica e a cristã.

No tempo cíclico, atualizado pela tradição e composto de ritos e repetições, o passado se apresenta como perfeição vindoura (ao fim de cada ciclo); e o presente e o futuro são constantemente atualizados nesse passado, cuja recorrência serve como antídoto às ameaças de mudança e/ou extinção (ibidem, p. 23). O tempo cristão, por sua vez, rompe com o tempo cíclico, ao enunciar o homem como protagonista do drama cósmico. A concepção de tempo torna-se linear, finita e pessoal. O homem precisa se afastar do passado (pecador) e caminhar em direção ao futuro. A mudança e a extinção (morte) são aplacadas pela promessa da vida eterna após o Juízo Final. Essas duas concepções de tempo - cíclica e cristã - oferecem um antídoto contra a morte: seja pelo retorno ritual do passado encarnado pela tradição; seja pelo Juízo Final que traz a promessa da vida eterna (aplacando o medo da morte).

A grande inovação da Modernidade, segundo Paz, foi mandar esse "antídoto contra a morte" às favas. A concepção histórica do tempo concebe, de forma eufórica, a morte (mudança, imprevisibilidade, extinção), libertando o futuro do passado (tempo cíclico) e do Juízo final (tempo cristão). O futuro se torna o tempo que "ainda não é e está prestes a ser", fértil "região do inesperado" (idem:28). Nesse sentido, a Modernidade passa ser concebida como uma "estética em que o desespero se alia ao narcisismo e afirma a morte" (idem:97). A emergência do tempo histórico, explica Paz, impactou, de forma cabal, a relação entre sociedade e tradição; esta passa a ser objeto de análise e de crítica. "A crítica da tradição se inicia como consciência de pertencer a uma tradição", e a "tradição moderna é, nesse sentido, "uma manifestação da nossa consciência histórica" (ibidem, p.21), afirma.

Além da emergência da razão crítica, a concepção do belo se transforma. Na Modernidade, aponta Paz, o transitório, o particular, o único e o estranho se tornam instrumentos de particularização da beleza: 
Graças à Modernidade, a beleza é uma, e sim plural. A Modernidade é aquilo que distingue as obras de hoje das de ontem, aquilo que as torna diferente e únicas (...), o elemento que, ao particularizá-la, vivifica a beleza. Mas essa vivificação também é uma condenação à pena capital. Se a Modernidade é o transitório, o particular, o único, o estranho, é a marca da morte (ibidem, p. 96-97).

Nesse sentido, Memórias Póstumas de Brás Cubas caminha em total consonância com os princípios dessa Modernidade. Publicada em 1881, a obra não apenas abraça a morte, como dá voz ao defunto, em narrativa profundamente crítica e autocrítica, como se nota no capítulo abaixo:

\section{CAPÍTULO CXXXIX / DE COMO NÃO FUI MINISTRO D'ESTADO}

(Memórias Póstumas, p. 249)

O trecho acima é exemplo de particularização da beleza pelo inusitado. $\mathrm{O}$ estranhamento é construído pela suspensão da explicação de como Brás Cubas não se tornou ministro de Estado. Convidado a participar como co-enunciador, o leitor imagina o ocorrido. Somente ele poderá preencher o conteúdo suprimido a partir dos indícios fornecidos pelo capítulo anterior (comentários sobre o discurso na Câmara) e posterior (lamento de Brás Cubas sobre a recusa do cargo); e de seu repertório sobre a doxa trabalhada pela obra. 
Ao mesmo tempo, a suspensão da narrativa enuncia a construção da própria narrativa, reforçando o percurso metalinguístico (característico na obra); e levando à confluência de, pelo menos, três diálogos distintos: o discurso do narrador que não consegue verbalizar o ocorrido, mas não pode esquecer a recusa do cargo, expressando sua indignação por meio da lacuna na narrativa; o discurso do co-enunciador (leitor) a quem cabe preencher o indizível a partir de repertório prévio e dos indícios oferecidos pela enunciação; e o discurso do enunciador da obra, responsável pela coesão que sustenta o estranhamento, garantido que o inusitado seja absorvido sem prejuízos à lógica narrativa.

\section{- Erótica da Modernidade}

Paz também salienta como característico nas produções dessa primeira vanguarda, a conquista do cotidiano, a inserção da fala coloquial e a crítica social. Em sua avalição, a Modernidade se impôs como práxis política aos artistas de vanguarda, manifestando-se como uma erótica, um ato político, um estilo de vida guiado pelo desejo de mudar a realidade e de revolucionar o mundo. O Modernismo, novamente, traz um exemplo contundente dessa erótica moderna na parábola "A escrava que não era Isaura" (1925), de Mário de Andrade.

Segundo o poeta, com inveja de Deus, Adão criou sua própria mulher e a deixou completamente nua, descansando no Monte do Ararat, região da Turquia, onde Noé teria estacionado sua Arca, após o mundo ser tragado por furiosas ondas. Sozinha no cume mítico, com o passar do tempo, essa mulher foi vestida por hábitos e gostos de várias culturas. Geração após geração, ela foi coberta por camadas de roupas até o dia em que um vagabundo, passando pelo cume, chutou o amontoado de vestimentas e se deparou com a mulher adâmica, novamente nua, esplendorosa. Uma mulher, frisa o modernista, "angustiada, ignara, falando por sons musicais, desconhecendo as novas línguas, selvagem, áspera, livre, ingênua e sincera". A mulher se chamava poesia e o vagabundo Artur Rimbaud (Andrade, 2009, p.231). 
A parábola expressa a dinâmica da tradição de deslocamentos, salientada por Paz, na qual o chute à tradição anuncia as pretensões modernistas. Salienta, também, como valores eufóricos a "selvageria", "aspereza", "liberdade", "ingenuidade", "sinceridade", embaladas pela promessa de redescoberta do país ou revelação de sua "essência"; na prática, a construção de nova vestimenta à literatura nacional. Em "O Movimento Modernista" (1942), conferência proferida na Biblioteca do Ministério das Relações Exteriores em 30 de abril de 1942, apresentando um balanço crítico e autocrítico do movimento, o autor afirma que

O espírito modernista que avassalou o Brasil, que deu o sentido histórico da Inteligência nacional desse período, foi destruidor. Esta destruição não apenas continha todos os germes da atualidade, como era uma convulsão profundíssima da realidade brasileira (...) O que caracteriza esta realidade que o movimento modernista impôs é, ao meu ver, a fusão de três princípios fundamentais: o direito permanente à pesquisa estética; a atualização da inteligência artística brasileira; e a estabilização de uma consciência criadora nacional (ibidem, 1943 , p. 248, grifos nossos).

Nota-se acima, entre os princípios evocados pelo Movimento, a presença da pesquisa estética e a necessidade de atualização que orientam a prática experimental, no caso, a serviço de uma "consciência criadora nacional". Somase a esses princípios, a crítica à moralidade burguesa e a qualquer submissão a um ideário estético europeu; a valorização das origens miscigenadas da sociedade brasileira e a introdução do "povo", recriado aos moldes desse ideário nas obras modernistas. Tratava-se, portanto, de várias propostas em torno de um Movimento que, segundo o escritor

(...) não era uma estética, nem na Europa, nem aqui. Era um estado de espírito revoltado e revolucionário que, si a nós nos atualizou, sistematizando como constância da inteligência nacional, o direito antiacadêmico da pesquisa estética e preparou o estado revolucionário das outras manifestações sociais do país, também fez isto mesmo no resto do mundo, profetizando estas guerras de que uma civilização nova nascera. (ibidem, p. 253) 
Sem dúvidas, um discurso acrático à doxa de seu tempo, inclusive, defendendo o "direito antiacadêmico da pesquisa estética". Já, em Paulicéia Desvairada, o poeta afirma a liberdade criadora, contrapondo-se à ideia de reprodução da natureza:

O poeta não fotografa: cria. Ainda mais: não reproduz: exagera, deforma, porém, sintetizando. $E$ da escolha dos valores faz nascer eurritmias, relações que estavam esparsas na vida, na natureza, e que a ele, poeta, competia descobrir e aproximar. Nisto consiste seu papel de artista (...) A natureza existe fatalmente, sem vontade própria. $O$ poeta cria por inteligência, por vontade própria. (Andrade, 2009, p. 273).

Crítico ao Realismo, o Modernismo afirma, assim, a criação artística como construção intencional, orientada por um projeto estético. A autoconsciência (razão crítica) é parte integrante do exercício criador - conforme vimos em Melo e Castro -, sem desconsiderar, em meio às descobertas freudianas daquele momento, os aspectos inconscientes do ato criativo:

A inspiração é que é inconsciente, não a criação. Em toda criação dá-se um esforço de vontade. Não pode haver esforço de vontade sem atenção. Embora a atenção para o poeta modernista se sujeite, curiosa, ao borboletear do subconsciente - a atenção continua a existir e mais ou menos uniformiza as impulsões líricas para que a obra de arte se realize (ibidem, p.279)

Outro aspecto salientado diz respeito à polifonia, compreendida por Mário de Andrade como simultaneidade de estímulos e superposição de ideias:

O nome de Polifonismo é a teorização de certos processos empregados quotidianamente por alguns poetas modernistas. Polifonismo e simultaneidade são a mesma coisa. O nome de Polifonismo caracteristicamente artificial deriva de meus conhecimentos musicais (...) A simultaneidade originar-se-ia tanto da vida atual como da observação do nosso ser interior. (Falo de simultaneidade como processo artístico). Por esses dois lados foi descoberta (...) Simultaneidade é a coexistência de coisas e fatos num momento dado. Polifonia é a 
união artística simultânea de duas ou mais melodias cujos efeitos passageiros de embates de sons concorrem para um efeito total final (ibidem, p. 304).

O polifonismo e a simultaneidade originam-se tanto na experimentação do cotidiano, quanto na observação do que o poeta define como "ser interior". A simultaneidade acena, inclusive, como parte integrante de uma percepção de mundo que não se manifesta de modo insular, mas como uma "sensação complexa total final", o que remete à concepção de "sincronia vital" de Melo e Castro. É nítido, portanto, o diálogo entre as várias concepções de vanguarda ao longo do século XX.

Em 1960, porém, o Brasil não só tinha sido "descoberto" por várias gerações modernistas, como se encontrava escancarado. A "construção da identidade nacional" reorientada por novos códigos de comportamento cabia aos meios de comunicação; e a realidade tematizada pela literatura se chocava frontalmente com o discurso oficial do Estado militar potencializado pelas novas tecnologias do período (televisão); denunciá-lo se tornava cada vez mais perigoso. Entre o primitivismo antropofágico e o tropicalista há uma distância histórica destaca Celso Favaretto em Tropicália, alegoria, alegria (1979). Questões como "originalidade da cultura brasileira" e "os aspectos étnicos", levantados pelo Modernismo, serão deslocados para o debate sobre a indústriacultural, as formas locais e os modelos artísticos importados, as questões político-econômicas, o subdesenvolvimento (Favaretto, 2007, p.61).

A ênfase dada pelos modernistas aos processos artísticos de vanguarda deu lugar a "vagas formulações teóricas, ao mito e ao poder encantatório da técnica", levando a "uma distância entre o material exposto, a devoração e os procedimentos que os estetizam". No caso da Tropicália, explica Favaretto, o "fundo técnico" da antropofagia é exatamente os valores da sociedade industrial expressos pela justaposição entre o arcaico e moderno, revelando as "indeterminações históricas", os "recalques sociais", o "sincretismo cultural" que desembocam, todos, em "cena fantasmagórica toda feita de cacos" (idem:58-9), como parece emular a última cena em PanAmérica, quando o narrador está 
literalmente flutuando em um bloco quebrado da narrativa, ao lado de outros blocos, pairando no espaço-texto.

Como poderemos observar ao longo deste trabalho, a postura antropofágica está presente nas três obras do nosso corpus, sobretudo, no que diz respeito à liberdade de criação, à revolução pela linguagem, à "festa" calcada na construção de uma narrativa sensorial e erótica por meio da fusão sincrética de outros domínios da arte. José Agrippino de Paula, Glauber Rocha, Ignácio de Loyola Brandão e tantos outros aprofundaram o experimentalismo realizado por essa primeira vanguarda, porém, sob perspectiva completamente disfórica em relação ao futuro. O experimentalismo das neovanguardas não caminha sobre os arranha-céus de outrora. Ele se esconde da polícia debaixo dos viadutos, transita por becos escuros em meio ao esgoto a céu aberto, e assiste à toda sorte de exploração da massa migrante que chega às cidades fugindo da fome.

\section{- Vanguardas do pós-Guerra}

Em sua análise, Octávio Paz afirma que não é a pós-Modernidade (ou qualquer outra denominação semelhante) a sucessora da Modernidade, mas sim as vanguardas que, ao longo do tempo, acabaram se tornando históricas. Ao se debruçar sobre as vanguardas do pós-Guerra, Paz elenca uma série de transformações, ressaltando como cruciais a mudança na concepção de futuro e a emergência de uma poética do agora.

O futuro, explica o crítico, passa a ser visto como horror; e o progresso, que até então anunciava o futuro como possibilidade, um verdadeiro desastre. Após o horror de duas guerras mundiais (1914/1918 e 1939/1945), o mundo ressurgia cindido pela polarização - capitalismo vs comunismo - da Guerra Fria (1945/1991). Dessa guerra, aliás, nem mesmo a Lua escapou ilesa: em 13 de abril de 1961, a Folha de S. Paulo estampava, com imagens do russo Yuri Gagarin, "Vencido o Cosmos: a URSS lança o primeiro astronauta ao espaço" (Publifolha, 2000:83). Nove anos depois, em 21 de julho de 1969, o mesmo jornal publicava a manchete "A Lua no Bolso", com as falas de Neil A. Armstrong e a 
bandeira norte-americana fincada no Mar da Tranquilidade lunar (ibidem, p.115). Tornando crível o inacreditável, a corrida espacial edificava as bases materiais e simbólicas de uma revolução tecnológica que, neste começo de século, vem promovendo radical transformação em quase todos os âmbitos da vida contemporânea.

Paz atribui a disforia desse futuro à derrocada das utopias marxistas que promoveu o deslocamento do futuro linear e progressivo (apontado pelo marxismo) para o horizonte plural das lutas por reconhecimento e direitos das chamadas minorias. A equação é simples: "a pluralidade de passados (latentes no tecido social) leva à pluralidade de futuros", introduzindo novos discursos na produção artística das vanguardas contemporâneas. Trata-se de um período de forte "afirmação da particularidade de cada grupo" em detrimento da "dissolução das classes em uma universalização dos homens" (Paz, 2013: 156-58), aponta o crítico.

Outro aspecto característico dessas produções, é a tematização do corpo, nas palavras de Paz, uma verdadeira "sublevação dos valores corporais e orgiásticos" em reação a duas restrições: "a condenação ao trabalho e a repressão do desejo" (idem:159). Sob o cristianismo, embora concebido como natureza caída, o corpo humano ainda poderia receber a graça divina, transformando-se em "corpo glorioso". No capitalismo, porém, o corpo é dessacralizado. Não é mais campo de batalha da luta do bem contra o mal, tampouco disputado por anjos ou demônios. O corpo, agora, não passa de instrumento de trabalho:

A concepção do corpo como força de trabalho levou imediatamente à degradação do corpo como fonte de prazer. $\mathrm{O}$ ascetismo mudou: já não era um método para ganhar o céu, mas uma técnica para aumentar a produtividade. O prazer é um gasto; a sensualidade, uma perturbação. (ibidem: 159).

Respondendo a essa degradação do corpo humano, a literatura das neovanguardas darão ênfase aos discursos que visam recuperar esse corpo castrado e reprimido pelas exigências de produtividade do sistema capitalista. 
Uma rebelião atada à explosão da imaginação, na medida em que o corpo "não é um manancial apenas de sensações, mas também de imagens":

Os transtornos da imaginação não são menos perigosos para a produção e o máximo rendimento que as sacudidas físicas do prazer sensual. Em nome do futuro completou-se a censura do corpo com a mutilação dos poderes poéticos do homem. Assim, a rebelião do corpo é também a rebelião da imaginação. Ambas negam o tempo linear: sues valores são os do presente (ibidem:160).

Dentro desse contexto, é possível localizar a vertigem figurativa de obras como PanAmérica, Zero e Riverão Sussuarana e a inserção de temas tabus, em geral, relacionados à vivência corporal e sexual. Paz avalia, inclusive, essa sublevação do corpo como retorno da sensibilidade e paixão dos românticos (alemães e ingleses), na medida em que ela promete a recuperação de uma sabedoria perdida. O corpo se apresenta, na contemporaneidade, como um caminho rumo ao presente e "ao agora em que vida e morte são metades de uma mesma esfera" (ibidem:160).

Essa poética do agora faz do presente um valor central na tríade temporal: passado e futuro não desaparecem, mas se tornam dimensões do presente e passam a participar do agora. No encontro desses dois tempos, a humanidade vê-se enredada por uma sensação contínua de imobilidade, em busca de um ponto no qual o princípio da mudança se confunde com o princípio da permanência (ibidem: 163). A arte de vanguarda passa então a se indagar: o que há em comum entre a "Odisseia" e "Em busca do Tempo Perdido"? E, podemos acrescentar, entre Zero e Serafim Ponte Grande.

Neste segundo capítulo, a partir das definições de Melo e Castro e Tabarovsky, pudemos elencar algumas características do exercício experimental, em especial, o papel da razão-crítica e a busca pela liberdade criadora. Em Barthes, aprofundamos a reflexão sobre as (im)possibilidades dessa liberdade, apresentando parâmetros que permitem localizarmos as obras experimentais. Também pudemos observar 0 diálogo entre literatura experimental e as vanguardas artísticas do século $X X$, a partir da definição de 
"tradição moderna" de Octávio Paz e das contribuições críticas de Mário de Andrade.

Além de situadas no contexto de sua contemporaneidade, por serem experimentais, assim que instauradas no discurso, essas narrativas evocam, pelo estranhamento que promovem, o texto tradicional; enunciando permanentemente o hiato entre convenção e experimentação, na medida em que efeitos de sentido das narrativas tradicionais, assim que suprimidos ou saturados, são imediatamente identificados. Isso demanda outra performance do enunciatário que, convertido em co-enunciador, é constantemente levado a preencher as lacunas de sentido decorrentes de sucessivas descontinuidades.

O "convite à festa" (Cf. Holanda e Hoisel) será dado pela ampliação das possibilidades de expressão do signo verbal, a partir de nova interação entre leitor e obra. Por mais estranhas que nos pareçam, a função delas é justamente causar o estranhamento, o impacto, o questionamento da passividade entre leitor e obra. Daí a investigação contínua e, por consequência, o diálogo permanente com experimentalismos adotados tanto pelas vanguardas do começo do século, quanto pelas neovanguardas contemporâneas a essas obras, como os movimentos pop, hippie, beat e outras leituras daquele período, reafirmando a "tradição da Modernidade" (Cf. Paz) em sua crítica permanente. 


\section{Participar da "festa": a revolução experimental}

O futuro prometido pelo século XXI chega a nós e impõe sua verdade retumbante: a de que o passado é território em permanente disputa. Quando a Constituição de 1988 foi promulgada, vigorava a perspectiva eufórica em torno da política, alavancada pela esperança democrática. Eram tempos de mobilização pelas Diretas Já (1983/1984), e de emergência de atores políticos e sociais como o Movimento dos Trabalhadores Rurais Sem Terra (MST), organizado em 1984, a partir das lutas pela reforma agrária; o Partido dos Trabalhadores (PT) em 1980, agregando ativistas, sindicalistas, religiosos, intelectuais e exilados políticos que retornavam ao Brasil; o Partido da Social Democracia Brasileira (PSDB) em 1987, dissidência do Movimento Democrático Brasileiro (MDB), que governaria o país com José Sarney, entre 1985 e 1989; além do surgimento ou retorno de várias legendas após a implosão do binarismo entre MDB e Arena, o assim chamado "partido" da ditadura.

Passados trinta anos, a euforia de outrora seria substituída pela perspectiva disfórica, em alguns casos contrária à democracia representativa ("o povo não sabe votar"), caindo ao extremo da criminalização da atividade política, dos políticos e seus partidos ("todo político é ladrão", "política não presta"), e chegando à eleição de uma extrema direita defensora de um preocupante discurso revisionista e anticientífico. Não é o caso aqui, evidentemente, de elencarmos os desmandos do governo em questão, mas de registrar a persistência do autoritarismo, a constante ameaça de oficialização de práticas fascistas (vide as falas sobre o Al-5) que nos aproximam dos discursos rechaçados pelas obras do nosso corpus.

Assim como nós, neste início de século XXI, Loyola Brandão, Agrippino de Paula e Glauber Rocha também foram obrigados a lidar com a polarização política, os ataques contra a Ciência e a Cultura, a dissimulação de fatos, a perseguição de lideranças populares, a tentativa de censura de informações.

As diferenças históricas, no entanto, são evidentes. 
Em 1964, o Brasil sofria o fechamento do regime, com tanques nas ruas e operações policiais em instituições públicas e privadas, prendendo trabalhadores, lideranças populares, sindicais, campesinas e formadores de opinião por simplesmente serem ou parecerem comunistas. O esfacelamento dos poderes Judiciário e Legislativo era percebido a olhos nus, do mesmo modo que a consolidação da opressão, em 1968. É este o contexto trazido por essas obras e a partir de uma linguagem essencialmente experimental, o que nos coloca diante de dois objetivos: contribuir com o acervo sobre a ditadura militar; e oferecer uma tipologia do experimentalismo praticado no romance brasileiro.

Os próximos dois capítulos deste trabalho serão dedicados à apresentação dessa tipologia. Para tal, nós contaremos com as contribuições teóricas de Jean-Marie Floch em Sémiotique, marketing et communication: sous les signes, les stratégies (PUF, 1990), que nos ensina a observar como os efeitos de sentido que constroem a ilusão de realidade são criados em PanAmérica, Zero e Riverão Sussuarana.

A partir de agora, nós iremos:

- Compreender cada um desses regimes com base nas ideologias observadas no discurso publicitário por Jean-Marie Floch; e nos regimes de construção semiótica observados no discurso pictórico por Antônio Vicente Seraphim Pietroforte;

- Observar como esses regimes são construídos nas três obras do nosso corpus, estabelecendo os elos de seu contexto histórico;

- Oferecer uma tipologia, com base nessas análises, do romance experimental contemporâneo (no quarto e último capítulo do presente trabalho). 


\section{$3.1 \mathrm{O}$ real enquanto efeito de sentido}

Em "Tués dans I óeuf!" (1990), Jean-Marie Floch observa como a ilusão de realidade é construída em várias peças publicitárias, analisando a relação entre o discurso publicitário e a realidade do produto por ele vendido. Não se trata apenas de questionar se o discurso $\mathrm{A}$ ou $\mathrm{B}$ corresponde à realidade, mas sim de investigar quais as condições de produção da realidade (internas a esses discursos) capazes de torná-los verdadeiros ou aceitos como verdadeiros.

Como aponta o linguista,

O debate dos publicitários é, a sua maneira, o dos semioticistas. Que os publicitários falem da relação entre publicidade e produto, ou que os teóricos da linguagem falem da relação entre discurso e mundo, implica a mesma pergunta sobre a função da linguagem - pouco importa se trata de linguagem verbal ou não verbal --. Os publicitários se questionam se para o consumidor o valor do produto é anterior à publicidade, ou se é a publicidade que o confere; os semioticistas, se a linguagem constitui a representação de um sentido já existente ou se representa a sua construção. Seja pela prática ou pela teoria, a publicidade e a semiótica conduzem a uma mesma e dupla problemática: a função da linguagem e a origem do sentido. (Floch, 1993, p.2017, tradução livre do espanhol ${ }^{21}$ )

Importante salientar que o modelo de construção da realidade observado por Floch, a partir do discurso publicitário, é valido para a análise de outros discursos, como o literário, conforme demonstraremos no terceiro capítulo deste trabalho, quando analisaremos o nosso corpus.

Floch parte das concepções de quatro ideólogos da publicidade francesa e mundial - D. Ogilvy, Ph. Michel, J. Séguéla e J. Feldman -, frisando o debate entre

\footnotetext{
${ }^{21}$ El debate de los publicitarios es, a su manera, el de los semióticos. Que los publicitarios hablen de la reacción entre publicidad y producto, o que los teóricos del lenguaje hablen de la relación entre discurso y mundo, implica la misma pregunta sobre la función del lenguaje -- poco importa que se trate de lenguaje verbal o no verbal --. Los publicitarios se preguntan si para el consumidor el valor del producto es anterior a la publicidad o si es la publicidad que se lo da; los semióticos, si el lenguaje constituye la representación de un sentido ya existente o si representa su construcción. Se llegue mediante la práctica o por la teoría, la publicidad y la semiotica desembocan en el mismo tipo de doble problemática: la función del lenguaje y el origen del sentido. (Floch, 1993, p.207)
} 
aqueles que sustentam a função representativa da linguagem (o homem quer interpretar a realidade - os objetos do mundo mediante seu discurso e apreensão do sentido "já presente"); e os partidários da função construtiva da linguagem, que negam a possibilidade ou a legitimidade de sua representação (o homem considera que somente conhece as coisas se construídas mediante o seu próprio discurso. Em termos mais profissionais, cabe dizer que se instaura uma oposição entre o valor inerente ao produto (que será manifesto ou usado pela publicidade) e o valor criado pela publicidade (ibidem, 211, tradução livre do espanhol ${ }^{22}$ )

Com base, portanto, na oposição entre função representativa vs. função construtiva, Floch encontrará quatro "ideologias da publicidade", como podemos observar no quadrado semiótico abaixo:

D. OGILUY

J. SEGUELA

PUBLICITE REFERENTIELLE

PUBLICITE MYTHIQUE

fonction représentationnelle du langage

$\uparrow$

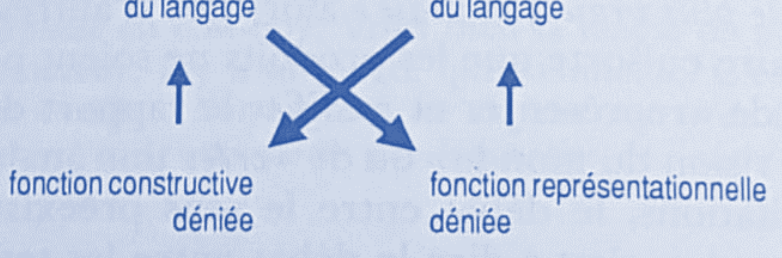

fonction constructive du langage

PUBLICITE SUBSTANTIELLE PUBLICITE OBLIQUE

J. FELDMAN

PH. MICHEL

(Floch, 1990, p.192)

\footnotetext{
22 El debate sobre el sentido anterior al lenguaje, o construido por él, se ha empredido a partir de estas citas, es decir, el debate entre quienes sostienen la función representativa del lenguaje (el hombre quiere interpretar la realidad -- los objetos del mundo -- mediante su discurso y captar el sentido "ya presente") y los partidarios de la función constructiva del lenguaje, que niegan la posibilidad o da legitimidad de dicha representación; el hombre considera que sólo conoce las cosas si se construyen mediante su propio discurso. En términos más professionales, cabe decir que se instaura una oposición entre el valor inherente al producto (que será manifesto o utilizado por la publicidad) y el valor creado por la publicidad. A partir del momento en que se proyecte sobre el cuadrado semiotico la categoria función representativa vs. función constructiva, que se ha reconocido como la articulación del universo de las ideologicas de la publicidad (Floch, 1993, p.211).
} 
Da oposição entre a publicidade referencial e a publicidade mítica, termos contrários, surgem dois outros regimes de construção semiótica: o oblíquo e o substancial. A publicidade oblíqua negará a publicidade referencial e afirmará a mítica; já a publicidade substancial, pelo contrário, negará a publicidade mítica, afirmando a referencial. Vejamos, brevemente, a característica de cada uma delas.

\section{- Publicidade referencial}

Floch identifica a ideologia referencial em propagandas que procuram manipular seu enunciatário a partir de efeitos de sentido relacionados às ideias de verdade, realidade, honestidade. É o que vemos, por exemplo, nas propagandas de sabão que trazem demonstrações e dados comparativos. As duas camisas estão brancas, mas uma é ainda mais branca que a outra; ou propaganda de dentifrícios que trazem depoimentos de dentistas "reais" visando atestar a idoneidade do discurso. Essa concepção de "publicidade da verdade", defendida por David Ogilvy, fundador da Ogilvy \& Mather, tende a criar um "referente interno" (dados, demonstrações, testemunhos etc.) criando a sensação de "realidade cotidiana" com "práticas, gestos e situações" que dão "efeito de densidade e de espessura ao vivido" (Floch, 1990, p. 193). São peças publicitárias acompanhadas de uma "verdade ética" - "a honestidade é finalmente constitutiva da competência criativa", dizia Ogilvy - mesmo sendo, como qualquer outra propaganda, uma estratégia discursiva, resultante de um esforço em tornar esse discurso verdadeiro para o enunciatário, e assim vender a maior quantidade de produtos possíveis.

\section{- Publicidade mítica}

Como sabemos, nem todas as peças publicitárias estão comprometidas com essa honestidade estratégica. Quem nasceu no Brasil antes do ano 2000, quando a publicidade de cigarros ainda era permitida, conhece a imagem do cowboy do Marlboro, citado por Floch como exemplo de publicidade mítica. 
Dentro dessa concepção, defendida por J. Séquéla, fundador da agência de comunicação RSCG, o discurso publicitário deve ser uma "máquina de fabricação da felicidade" voltada a "disfarçar o tédio das compras do cotidiano, revestindo de sonho os produtos que, sem a publicidade, seriam apenas aquilo que eles são" (Floch, 1990, p. 191). O caso das propagandas de cigarro é notório:

Figura 6 - Eric Lawson, o $4^{\circ}$. Cowboy da Marlboro morto por doença pulmonar
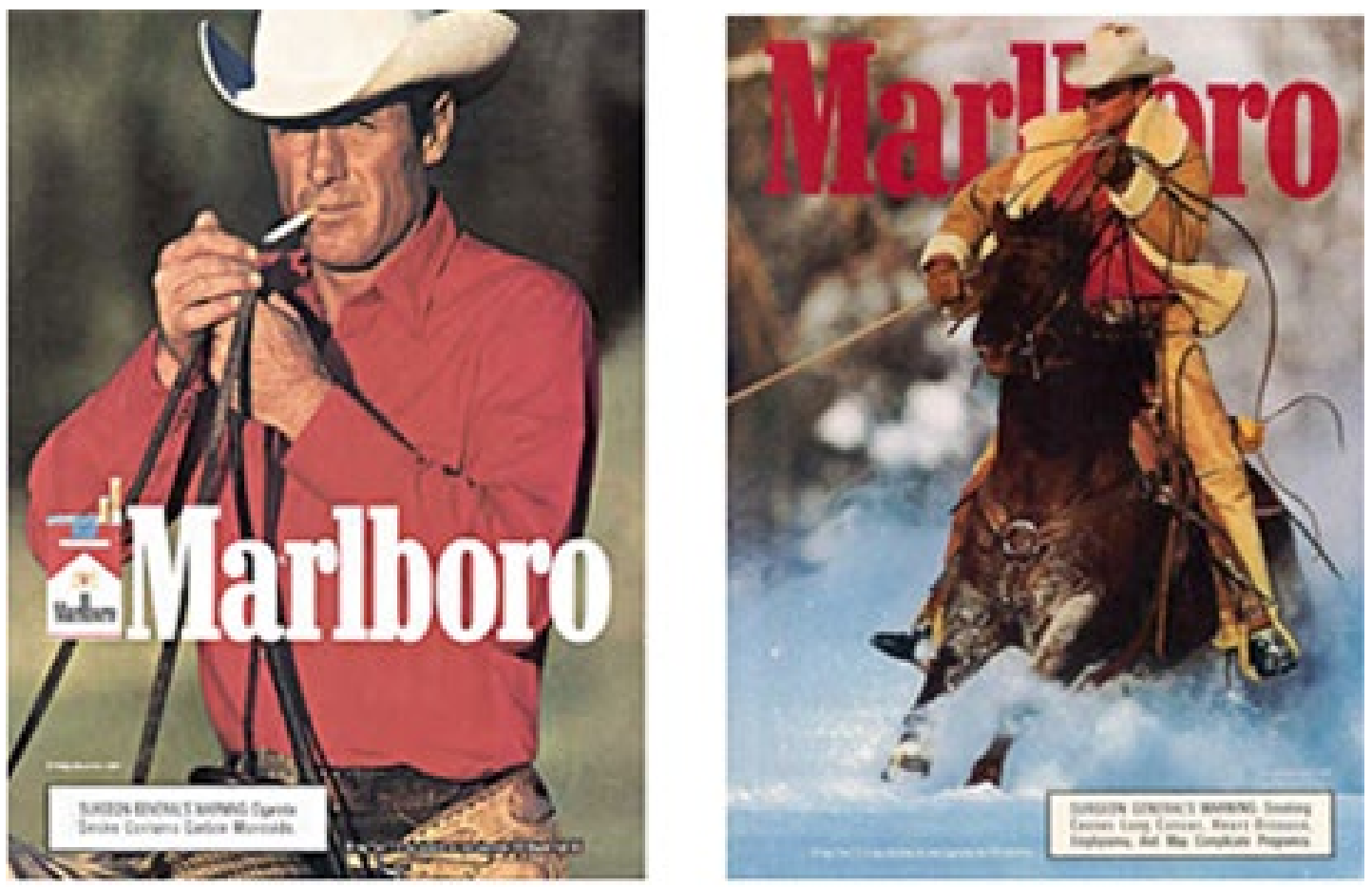

Fonte: Estado de Minas, 27.01.2014, online

Depois de cavalgar pelas belas paisagens do Oeste norte-americano, de laçar touros e acarinhar o fiel pastor alemão, o cowboy de Marlboro retira do bolso o fatídico maço de cigarros, e observa o poente. Tosse, cansaço, insônia, pigarro, manchas no pulmão, nada abala o cowboy de Marlboro, apesar do tabaco matar até metade de seus usuários, de quatro garotos-propaganda da marca terem morrido de complicações relacionadas ao tabagismo ${ }^{23}$; de oito

${ }^{23}$ David Millar Jr., o primeiro Cowboy, morreu de efisema pulmonar em 1987; Wayne McLaren de câncer no pulmão em 1992; David McLean, de câncer no pulmão em 1955; e Eric Lawson em 2014. Acesso em 26 nov. 2019, Disponível em: < 
milhões de pessoas morrerem a cada ano dessas mesmas complicações (OPAS/OMS, 201924).

Eis o imenso poder da publicidade mítica.

\section{- Referencial vs. Mítico}

Para explicar a relação de contrariedade entre esses dois regimes de construção de realidade, o referencial e o mítico, Floch utiliza um exemplo da literatura. Ele parte da oposição representação vs. construção do real para apontar a existência de uma literatura referencial, na qual os personagens são dados de antemão, ou seja, eles surgem completos na narrativa:

Fala-se de um tirano ou de um dragão, de um jornalista ou de um jovem príncipe, e a história que se empreende consistirá em "esvaziar" essas pessoas, utilizando-as como verdadeiros bancos de situações e ações (Floch, 1993, p.220, tradução livre do espanhol ${ }^{25}$ )

Floch também observa a existência de uma literatura mítica, na qual os personagens são construídos ao longo da obra:

Pelo contrário, há literaturas ou histórias feitas de tal forma que os acontecimentos e o desenvolvimento progressivo da intriga "se preenchem", vão construindo aos poucos os personagens que estavam vazios no início. (Floch, 1993, p.220, tradução livre do espanhol ${ }^{26}$ )

https://www.em.com.br/app/noticia/internacional/2014/01/27/interna_internacional,492176/morr e-mais-um-cowboy-da-marlboro-o-4-por-doenca-pulmonar.shtml >

${ }^{24}$ O Portal Organização PanAmérica de Saúde (OPAS)/ Organização Mundial de Saúde (OMS) traz estes e outros dados sobre o tabagismo mundo. Acesso em 26 nov. 2019. Disponível em: < https://www.paho.org/bra/index.php?option=com content\&view=article\&id=5641:folhainformativa-tabaco\&ltemid=1097 >

${ }^{25}$ Hay literatura cuyos personajes están "Ilenos" desde el principio: se habla de un tirano o de un dragón, de un periodista o de un joven príncipe, y el relato que se empreende consistirá en "vaciar" a estos personagens, en utilizarlos como verdaderos bancos de situaciones y de acciones. (Floch, 1993, p.220)

${ }^{26}$ Por el contrario, hay literaturas o relatos hechos de tal manera que los acontecimientos y el desarrollo progresivo de la intriga "llenan", construyen poco a poco los personajes que estaban vacíos al principio. (Floch, 1993, p.220) 
Dois romances de Mário de Andrade, Amar, Verbo Intransitivo (1927) e Macunaíma (1928), permitem-nos visualizar a predominância de um ou outro modelo.

Em Amar, VI, crônica picante e bem-humorada dos costumes da burguesia paulistana nos anos 1920, nós conseguimos ver, nitidamente, a burguesia agrária e interiorana se transformando em burguesia urbana, e assumindo novos trejeitos e valores. Para mostrar essa transformação, os personagens são bem definidos: o casal burguês que contrata a governanta alemã para iniciar sexualmente o primogênito da família. Esses tipos - os pais, a governanta, o menino - são extraídos do mundo referencial, ou seja, se andássemos pela capital paulista em 1920, facilmente nós os reconheceríamos. Temos, portanto, uma realidade construída a partir do mundo tal como o conhecemos ou imaginamos conhecer. A crítica em Amar, VI se deve, aliás, à exposição dessas minúcias.

Já em Macunaíma, ocorre o contrário. A crítica se deve ao distanciamento da realidade. Herói ou anti-herói - Macunaíma não existe fora da mítica constituída no romance, pertence àquela lógica; e desde seu nascimento, a imprevisibilidade está posta. Neste romance, os atores são definidos conforme o desenvolvimento da trama, e é impossível saber o que ocorrerá com eles e, em particular, com Macunaíma na sua busca pela muiraquitã, o talismã mágico. Bem-humorado e trapaceiro, do começo ao fim do romance, Macunaíma dará corpo a essa mítica, e será expresso em uma linguagem não menos experimental que a das obras do presente corpus.

De modo geral, podemos observar as seguintes características em torno desses dois regimes de construção da realidade: 
Tabela 1. Regime referencial vs. Regime mítico

\begin{tabular}{|c|c|}
\hline Regime Referencial & Regime Mítico \\
\hline $\begin{array}{l}\text { - Reconhecimento imediato das } \\
\text { referências do mundo (real) no } \\
\text { discurso } \\
\text { - Personagens e cenário construídos a } \\
\text { partir de referências do mundo } \\
\text { vivido } \\
\text { - Realismo, naturalismo } \\
\text { - Presença do referencial: descrição, } \\
\text { citação } \\
\text { - Descrição e reiteração do sistema } \\
\text { tradicional da língua }\end{array}$ & $\begin{array}{l}\text { - Construção de um outro mundo } \\
\text { revelado ao longo do andamento do } \\
\text { discurso } \\
\text { - Personagens e cenário construídos } \\
\text { com o desenrolar da trama } \\
\text { - Épica, fantasia, ficção científica } \\
\text { - Presença de símbolos universais e } \\
\text { - } \text { aleguetípicos: construção do mito } \\
\text { verbal }\end{array}$ \\
\hline
\end{tabular}

\section{- Publicidade oblíqua}

A publicidade oblíqua irá negar a referencialidade e afirmar a publicidade mítica. Nela, o sentido é construído pelo consumidor. Como explica Floch, tratase da "publicidade do paradoxo que literalmente vai contra a opinião comum, baseando-se em algo que está fora do lugar". Uma publicidade cerebral, defendida por Philippe Michel, fundador da agência CLM BBDO, que concebe o enunciatário como "sujeito de um fazer interpretativo" e cuja "inteligência deve ser colocada à prova”. Caberá a ele construir o sentido do discurso, nunca dado de antemão. Ele será visto como um "ser que pensa", um "coprodutor de sentidos", e a publicidade "como o espaço destinado a euforizar essa compreensão" (Floch, 1990, p.196).

Abaixo, a título de exemplo, o cartaz de uma das publicidades oblíquas trazidas por Floch. 
Figura 7. - Publicidade oblíqua

\section{Paris e Amsterdã, ida e volta, 30 francos}

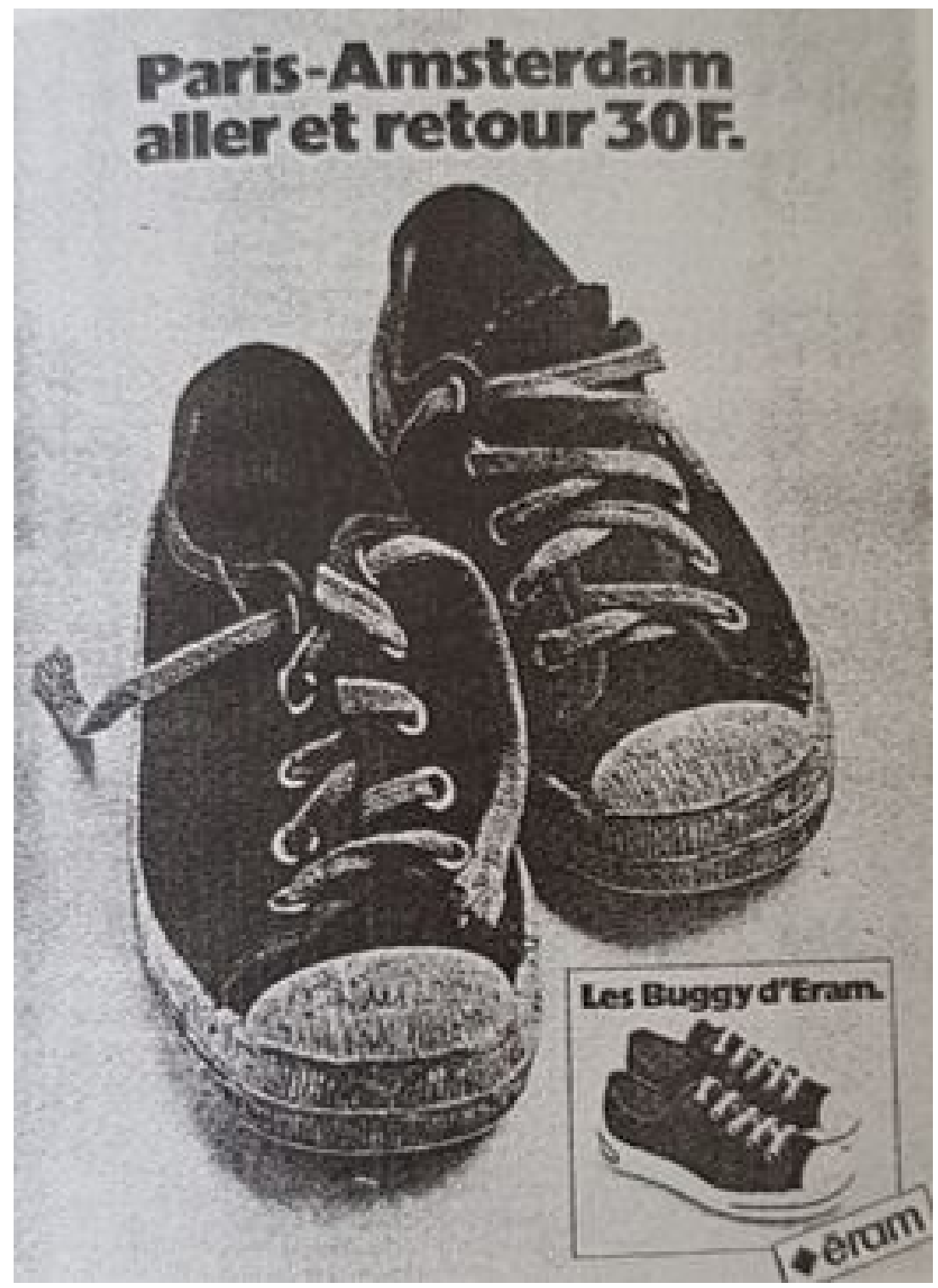

Fonte: Floch, 1990, p.213

O que se vende nesta imagem? Obviamente, muito mais que um tênis usado. O que está em jogo aí é o caminho percorrido pelo tênis, ou seja, a aventura da viagem a pé entre Paris e Amsterdã. A obliquidade parte da referencialidade (o tênis, a estrada, a viagem) transformando-se em um contínuo devir (todas as aventuras imagináveis) em afirmação da mítica. No entanto, este “cair na estrada” precisa ser lido e deduzido pelo enunciatário. 
Daí o caráter cerebral desse tipo de publicidade que dará ao enunciatário a liberdade de sonhar e construir, a partir de suas próprias referências, o objeto de valor (a aventura) acoplado ao par de tênis usado. Como explica Floch, a obliquidade é uma construção discursiva que visa "transformar a percepção que temos dos objetos" (ibidem, p.197).

\section{- Publicidade substancial}

Na publicidade substancial, contrariamente à oblíqua, o que ocorre é a negação do discurso mítico e a afirmação do discurso referencial. Defendida por Jean Feldman, fundador da FCA!, essa publicidade irá recusar o distanciamento e a racionalização exigidos pela publicidade oblíqua, propondo a "recentralização do objeto", a explicitação de "sua natureza profunda", suas origens e os atributos de sua constituição.

Embora aponte para o regime referencial, a publicidade substancial promoverá uma emoção estética relacionada à "suspensão do tempo", construindo o sentimento de uma "presença física" do objeto ante o enunciatário, inclusive, promovendo um "estranhamento do mundo" através do qual "o objeto parece avançar sobre o enunciatário", sendo "quase" possível tocá-lo (ibidem, p.205-206). Segundo Floch, a propaganda substancial "inverte a relação do sujeito com o mundo. É o acontecimento que provoca a suspensão do tempo", no qual são os objetos que nos observam (ibidem, p.208).

É justamente esse o efeito de sentido da publicidade abaixo, trazida por Floch como exemplo de propaganda substancial, em que podemos ver a imagem de uma gigantesca bolacha, da marca Petite Beurre, ocupando todo o espaço da foto, seguida do texto: "Manteiga tudo bem, mas pequena, por quê?", euforizando a constituição física do produto (manteiga) e problematizando o "pequeno" em seu nome, em franco contraste com a imagem do cartaz: 
Figura 8 - Publicidade substancial - Floch

Manteiga tudo bem, mas pequena, por quê?

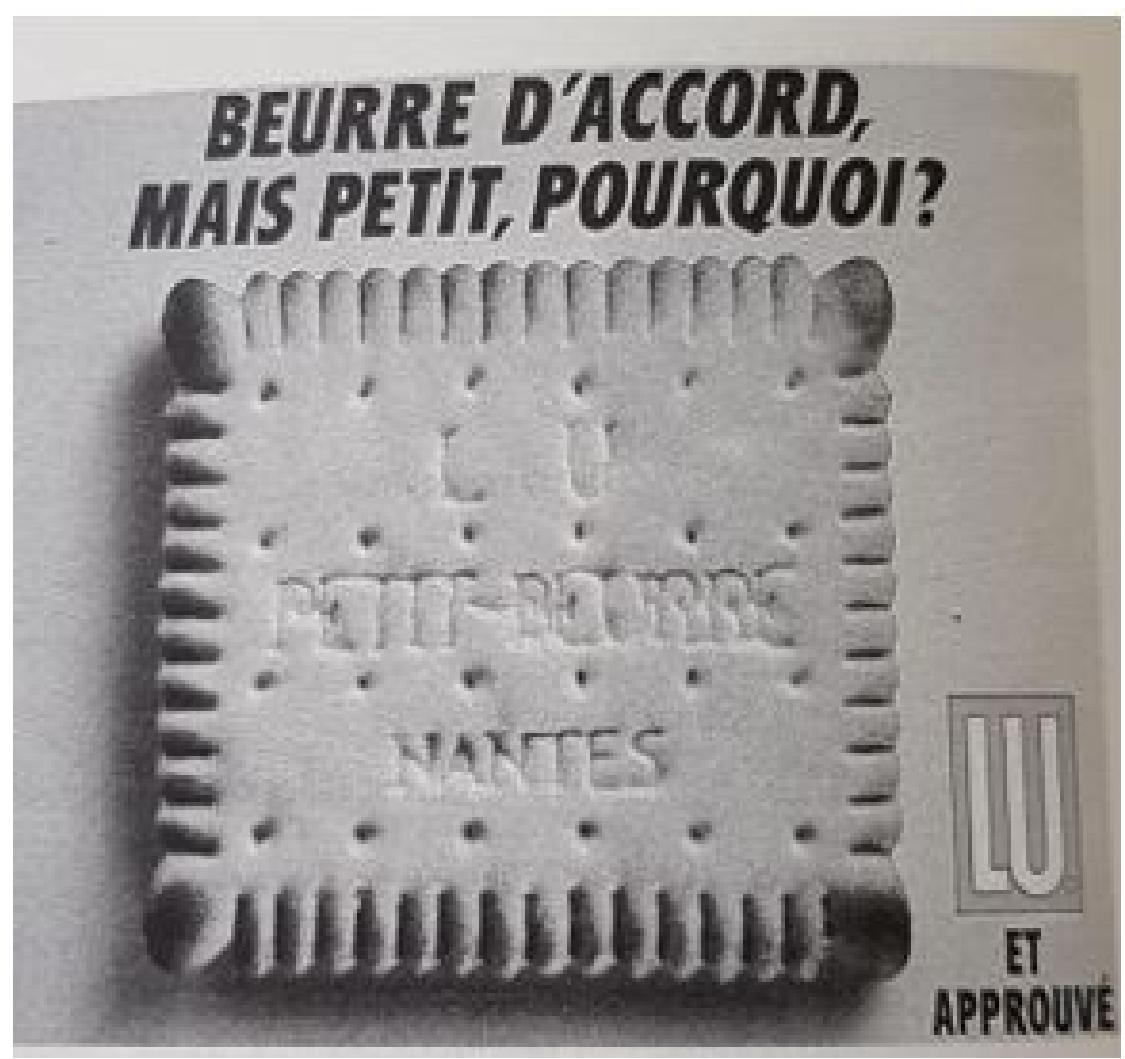

Fonte: Floch, 1990, p.218

Na mesma toada, poderíamos pensar no famoso jingle do McDonald's que ressalta item por item de um dos sanduíches mais famosos da rede, o Big Mac, refletido sonora e visualmente os ingredientes caindo sobre o pão do sanduíche, obviamente, muito mais volumoso, saboroso e aromático que o pão comum na caixinha do fast food que constitui a realidade de cada dia.

\section{- Linguagem visual}

Em A significação da Pintura (2016), Antonio Vicente Seraphim Pietroforte (Linguística e Literatura Comparada - USP) traz uma releitura do modelo desenvolvido por Floch em Semiotique, marketing et communication (1990) e, também, em Les Formes de L'Empreite (1987). 
Em seu trabalho sobre a pintura, ele transpõe o quadrado semiótico para um "eixo de articulação semiótica", trabalhando as ideologias identificadas por Floch enquanto regimes de construção semiótica, afinal, tratando-se de "um eixo, portanto, de uma continuidade, é possível verificar gradações seja no percurso da negação do regime referencial, seja no percurso contrário: o da negação do regime mítico" (Pietroforte, 2016, p. 126). No presente trabalho nós adotaremos tanto o eixo quanto a terminologia apresentada por Pietroforte.

\section{Gráfico 1. Eixo de articulação semiótica}

\section{Oblíquo}

(negação do regime referencial e afirmação do regime mítico)

Referencial

Mítico

\section{Substancial}

(negação do regime mítico e afirmação do regime referencial)

Como exemplo da referencialidade na pintura, Pietroforte cita as chamadas "pinturas figurativas" como a obra renascentista Os duques de Urbino Federico da Montefeltro e Battista Sforza (figura 9) de Piero della Francesca, que traz dois nobres (que realmente existiram) em uma pintura que, para além de todas as características renascentistas, estabelece imediata relação com a suposta realidade do mundo.

Esse quadro irá se contrastar, de modo visceral, com o Quadrado Negro de Kazimir Malevicht, identificado por Pietroforte como obra mítica, na medida em que "os processos construtivos da linguagem são revelados" (Pietroforte: 2016, p.127), obedecendo a uma lógica interna que não dialoga com a realidade do mundo. No caso, o quadro afirma todo ideário suprematista, defendido por 
Malevicht e pelo poeta Maiakovski no manifesto Do cubismo ao suprematismo (1915) onde ambos partem em defesa da supremacia do puro sentimento e da pura sensibilidade plástica. O impacto gerado pela aproximação visual das duas obras é autoexplicativo:

Figura 9 - Pintura referencial

Figura 10 - Pintura Mítica
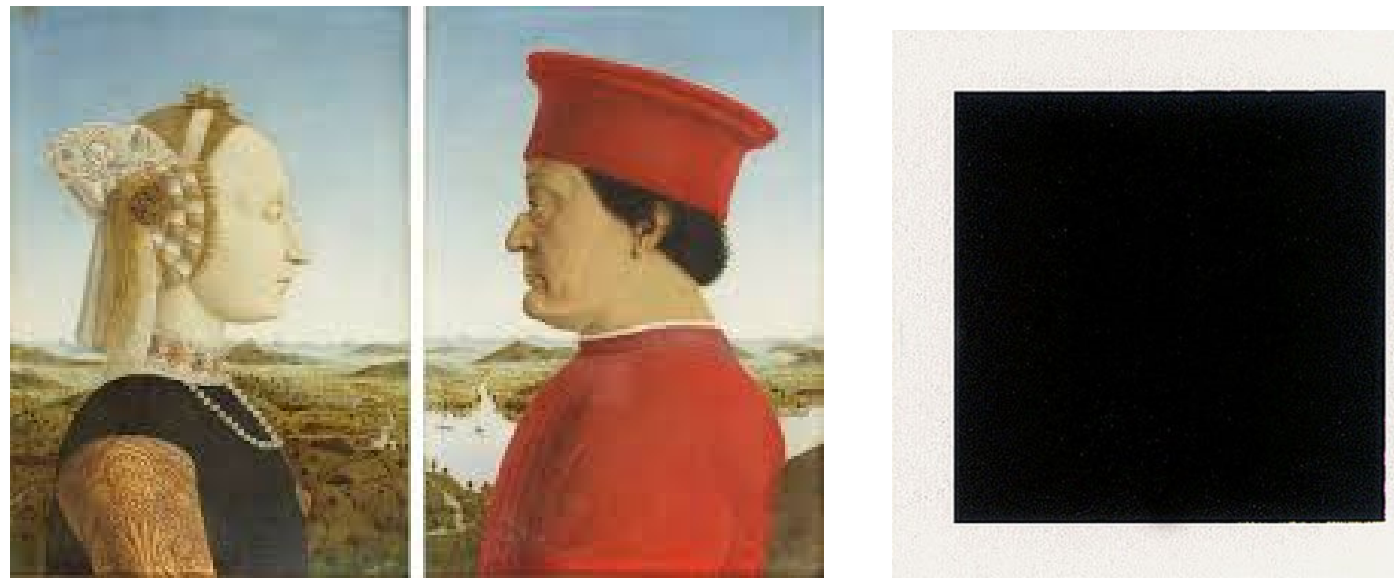

Figura 8 - Os duques de Urbino Federico da Montefeltro e Battista Sforza - Piero della Francesca Figura 9 - Quadrado Negro - Kazimir Malevicht

Entre esses dois polos, Pietroforte identifica gradações de obliquidade e de substancialidade. Ele ensina que na pintura, a obliquidade se manifesta quando os processos construtivos da linguagem são introduzidos em meios a processos referenciais, e "os efeitos de sentido gerados sugerem a aparência da referencialização, mas sem afirmar explicitamente a linguagem enquanto construção" promovendo uma "plurivocidade poética do sentido" (ibidem, p. 127). Isso ocorre, quando a presença do enunciador é identificada no enunciado, revelando sua subjetividade e em situações de metalinguagem, quando a prática enunciativa é explicitada, como podemos observar no quadro Davi com a cabeça de Golias de Caravaggio (figura 11), que traz a cabeça decapitada do próprio pintor no papel de Golias. 
Figura 11- Pintura Oblíqua

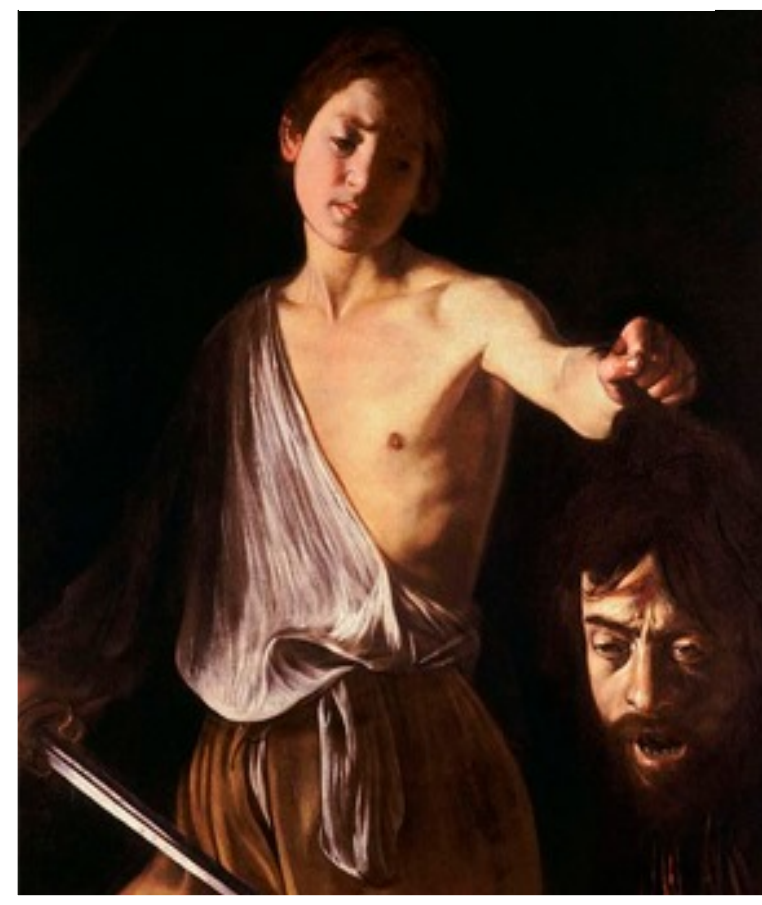

Figura 12 - Pintura

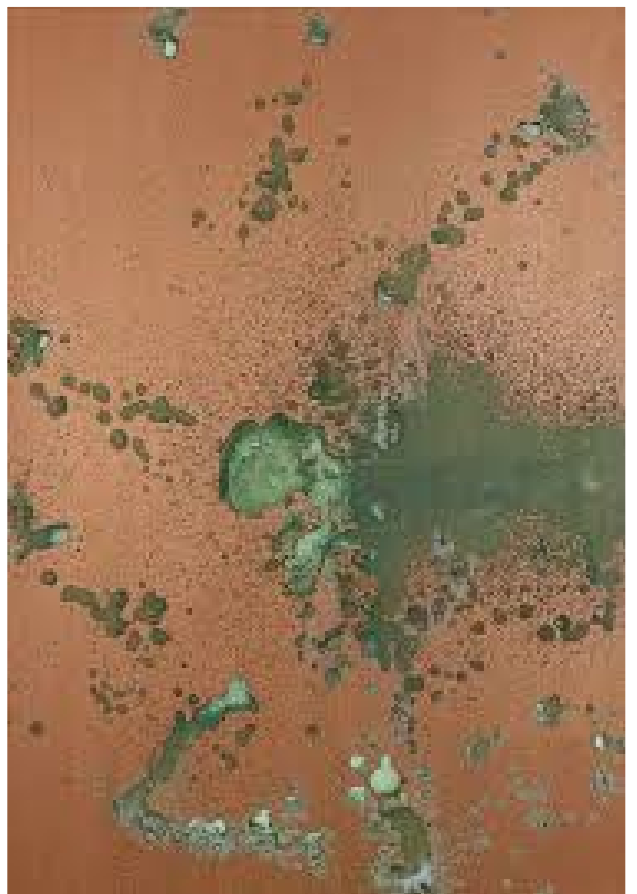

Figura 10 - Davi com a cabeça de Golias de Caravaggio

Figura 11 - Quadrado Negro de Kazimir Malevicht

O regime substancial, por sua vez, irá valorizar os aspectos constitutivos da obra de arte, no caso da linguagem pictórica, seus componentes materiais, como explica Pietroforte:

Como o regime mítico concentra-se no enunciado, priorizando as relações entre as formas semióticas geradas pelas categorias cromáticas, eidéticas e topológicas, sua negação implica na substancialização dessas relações formais nos componentes materiais da pintura (Pietroforte, 2016, p.131)

Um exemplo da substancialização pode ser visto em Oxidation Paintings (Figura 12), a série de quadros de Andy Warhol pintados com a urina do autor, em um processo de fusão entre materialidade da obra e corpo do artista.

De modo geral, os modelos de Floch e Pietroforte nos permitem compreender que 
a referência é um efeito de sentido, e não o fundamento da significação. Não se trata, portanto, de refletir a realidade, mas de construí-la em função de um determinado regime semiótico; trata-se de construir mundos possíveis nos quais a realidade encontra-se representada em regime referencial, oblíquo, mítico ou substancial. (Pietroforte, 2016, p. 134).

Com base nesses quatro regimes nós iremos, a partir de agora, verificar como eles se expressam na linguagem literária, e como suas ideologias dialogam com o contexto dessas obras, na medida em que as figuras e temas trabalhados por elas dizem respeito a episódios, personagens e personalidades daquele momento. Em nossa hipótese, o experimentalismo contrariamente à alcunha de "arte alienada", revela-se poderosa ferramenta não apenas de investigação e fruição estética, mas de contestação política do real. Daí a pertinência em observarmos esses quatro regimes de construção da realidade, observando como, por meio de inovadores modos, foram vocalizadas as mais diversas rupturas e continuidades que marcaram, ao longo de 21 anos, a última experiência de autoritarismo de Estado que vivemos enquanto nação.

\section{- Inquietações iniciais}

Importante salientar que Floch e Pietroforte nos trazem um primeiro e urgente desafio relacionado à obliquidade inerente à linguagem experimental. Como vimos, o experimentalismo atua sobre um modus operandi minimamente estabilizado, um "padrão" que não constitui regras, afinal, estamos no território da criação poética, mas que se coloca enquanto o "Outro" da convenção, com quem a prática experimental irá dialogar, problematizar, subverter. Um "Outro", aliás, também resultante da incorporação já estabilizada de sucessivas subversões anteriores, afinal, a Literatura não é estanque, ela está sempre em mutação, daí seu caráter de tradição moderna (cf. Paz, p.96).

O que nos instiga é que, contrariamente aos romances que buscam apagar seus aspectos constitutivos, as narrativas experimentais se desdobram 
por destacá-los, o que gera uma pronta denúncia dos aspectos constitutivos da criação literária.

O fato é que sempre que aplicarmos o modelo de Floch à totalidade dos romances contemporâneos da literatura brasileira, ou seja, sempre que compararmos diferentes narrativas, experimentais e não experimentais, buscando classificá-las segundo os regimes referencial, oblíquo, substancial ou mítico, as produções experimentais serão consideradas obras de regime mítico. Primeiro, pela denúncia dos aspectos constitutivos da ficção literária que promovem; segundo, porque essas obras, ao contrário das não experimentais, são regidas por uma lógica interna-operam dentro de leis muito particulares.

Agora, todas as obras experimentais são míticas?

O que demonstraremos, a partir de agora, é que não. Quando aplicamos o modelo de Floch em obras experimentais, o que descobrimos é a presença de todos os regimes acima elencados e a predominância de um desses regimes, 0 que é de extrema valia na constituição de uma tipologia dos romances experimentais, porque nos permite, em meio à heterogeneidade que compõe essas obras, um modelo comparativo entre experimentalismos praticados num mesmo regime de construção da realidade, o que nos leva a outras questões como: é possível construir efeitos de sentido atados à referencialidade neste tipo de narrativa? Como esses regimes nos ajudam a construir um olhar menos subjetivo, e mais generoso em relação às obras experimentais?

Cientes de que o sentido, tal como nos ensina a semiótica narrativa, resulta de um sistema permanente de relações, a adoção do quadrado semiótico de Floch, longe de instaurar redução ou simplificações, evidencia as relações de contrariedade e complementariedade entre termos que nos permitem analisar, com menor subjetividade, objetos ainda carentes de tipologias ou propostas de análise como as narrativas experimentais que precisam ser valoradas à luz de outras obras experimentais, como ocorre em outras linguagens, vide a música ou as artes plásticas, ninguém em sã consciência irá comparar uma peça dodecafônica com uma música tonal.

Cada obra experimental irá aturdir seu enunciatário ao seu modo, o que não significa impossibilidade crítica, pelo contrário, elas precisam da crítica, 
inclusive, para que suas diferentes camadas de sentido se tornem mais e mais acessíveis ao público leitor. Não é a crítica que essas obras rechaçam, mas sim a normatização, o certo e o errado, a dessensibilização do olhar voltado apenas ao mercado ou receoso ante a insegurança que essas narrativas provocam ao retirarem o conforto das nossas bases teóricas.

O papel do experimentalismo é o da desestabilização da linguagem, de onde surgem os mais diferentes devires. Daí a dificuldade de investigarmos essas obras, e encontrarmos características comuns que nos permitam compará-las. O que iremos propor é um primeiro passo neste sentido, a partir da investigação das relações entre as obras experimentais, mais especificamente da obliquidade em PanAmérica, da referencialidade em Zero e da substancialidade em Riverão Sussuarana. Obras que "participam da festa" (Hoisel, cf.1980) revolucionária, mobilizando diferentes estratégias e linguagens na construção de um impactante grito contra o autoritarismo que, mais de trinta anos depois, ainda persiste. 


\subsection{O regime oblíquo em PanAmérica}

Em 1967, quando José Agrippino de Paula lançou PanAmérica, as eleições estavam proibidas no Brasil. Era o terceiro ano do golpe e o retorno à democracia se apresentava mais e mais distante. Lideranças dos movimentos populares, sindicais, camponesas eram perseguidas e presas. Nas ruas, aconteciam protestos e o discurso contra o autoritarismo crescente estava em plena ebulição. Correspondendo à necessidade de estudantes e trabalhadores por formas coletivas de fruição da arte, o Teatro mantinha a dianteira da resistência cultural. E a TV, ainda incipiente, transmitia os Festivais da MPB, mobilizando as pessoas em torno dos artistas do "iê-iê-iê", dos artistas engajados da esquerda e da desconcertante juventude tropicalista. As passeatas se avolumavam, e até contra guitarra elétrica houve marcha, dividindo a opinião de artistas como Agrippino de Paula que, em seu segundo romance, de modo completamente inusitado, articulava as ideologias da Guerra Fria e a mitologia da cultura pop.

Nascido em 1937, Agrippino se formou arquiteto pela Universidade Federal do Rio de Janeiro (UERJ) e contou, já em seu primeiro livro, Lugar Comum (Civilização Brasileira, 1965), com prefácio de Carlos Heitor Cony que então comemorava: "ganha a literatura brasileira um novo criador" (De Paula, 2004, p. 5). Dois anos depois, integrado à vanguarda cultural dos anos 1960 , lançava PanAmérica, também pela Civilização Brasileira, com prefácio do cientista e crítico de arte Mário Schenberg que o apontava como "uma das personalidades mais poderosas e significativas da nova geração de escritores brasileiros". Neste prefácio, Schenberg oferece uma das melhores sínteses da obra, classificando-a como uma "epopeia contemporânea do Império Americano", e enfatizando a "utilização literária de mitos fundamentais contemporâneos" produzidos pela "máquina contemporânea da produção de mitos modernos" que é Hollywood (PAN, p. 11).

Construindo personagens a partir dos signos do mass media, como Marylin Monroe, Joe DiMaggio, Harpo Marx, entre outros, Agrippino permite um debochado vislumbre dos principais ícones do Olimpo hollywoodiano; e uma 
crítica, não menos debochada, da Guerra Fria, seus mocinhos e bandidos, metaforizada na batalha entre o Norte imperialista (Estados Unidos) e o Sul (América Central e Latina).

Autêntico multiartista, com diversificada produção além da literatura, Agrippino de Paula teve atuação importante no cinema marginal e na dramaturgia brasileira, respirando o ambiente cultural de seu tempo, a ponto de ser chamado de "guru" pelos jovens tropicalistas, embora nunca tenha assumido o posto, tampouco abraçado a Tropicália como escola. Foram esses jovens que eternizaram a obra, em particular, os versos de Caetano Veloso em Sampa com sua "PanAmérica de Áfricas utópicas"; bem como a canção "Eu e ela estávamos ali encostados na parede", excerto do romance musicado pelos Doces Bárbaros.

Reconhecido no contexto underground mais por seus filmes do que por seus livros, Agrippino é referência do cinema marginal brasileiro pelo longa Hitler, Terceiro Mundo (1968); e diversos curtas-metragens produzidos juntamente com a bailarina Maria Esther Stockler. Dessa parceria surgiram peças de teatro como Nações Unidas (1968) e Rito do Amor Selvagem (1970), além do grupo teatral Sonda, reconhecido pela experimentação estética. Em meio a isso, Agrippino promoveu o lendário show O Planeta dos Mutantes, que traria à cena o trio formado por Rita Lee, Sérgio Dias e Arnaldo Baptista. Em cada uma de suas obras é possível identificar a experimentação enquanto prática escritural, e em diferentes linguagens, teatro, cinema e literatura.

Depois do Al-5, porém, a pujança criativa de Agrippino e Maria Esther sofreria seu primeiro revés. Em 1971, vigiados pela repressão, por conta do estilo de vida que levavam, eles foram levados para o Departamento de Ordem Política e Social (DOPS) e obrigados a passar ali uma noite. O episódio fez com que partissem em autoexílio para o continente africano, onde registraram práticas culturais locais em curtas metragens belíssimos, como Candomblé no Tongo ${ }^{27}$ (1972) que traz uma roda de candomblé filmada por Agrippino em uma comunidade rural no Sudoeste do Níger. De volta ao Brasil, eles ainda produziram curtas-metragens na Bahia, onde se fixaram até Agrippino ser

${ }^{27}$ Candomblé no Tongo está disponível no YouTube sob o título "Agrippino Candomblé no Dahomey" (inserido em 13.04.2015), conta com mais de dez mil visualizações. Disponível em: < https://youtu.be/2F-6ugtqxTk >.. 
diagnosticado esquizofrênico. Retornando a São Paulo, Agrippino de Paula se instala em Embu das Artes, no interior paulista.

Desde então amigos e admiradores do multiartista reavivam sua vigorosa produção artística. Em 1980, Evelina Hoisel (UFBA) publicou análise pioneira, e de referência, sobre PanAmérica e a peça Nações Unidas (1968): Supercaos: os estilhaços da cultura (1980). Em 1988, a videomaker Lucia Meirelles, então curadora do acervo do multiartista no Museu da Imagem e Som (MIS), expôs sua obra cinematográfica e produziu o curta Sinfonia PanAmérica evidenciando a simultaneidade, a velocidade e a fragmentação na obra do artista. A partir de 2001, a literatura de Agrippino passou a ser reeditada pela Editora Papagaio, comandada por Sergio Pinto de Almeida. Foi neste período que o autor passou a dizer que se tivesse em mãos uma Super 8, ele voltaria a filmar. A psicanalista e cineasta Miriam Chnaiderman conta essa história no curta-metragem Passeios no Recanto Silvestre, de 2006. Um ano depois, aos 70 anos de idade, Agrippino faleceria em São Paulo.

Cinco anos depois, em 2012, durante seminário sobre Agrippino de Paula, o SESC-SP lançou o box Exu 7 Encruzilhadas com toda obra audiovisual do multiartista. Filmes, curtas-metragens, canções e declarações de artistas contemporâneos, influenciados por sua produção, expressam o vigor de uma produção experimental que, observa o cineasta Carlos Reichenbach, traz "a compreensão do demiurgo". O escritor Jorge Mautner, por sua vez, define Agrippino como "hipermonge-primitivista"; "um óvni que encarna ao mesmo tempo mito e Modernidade" acrescenta o poeta Arnaldo Antunes; dotado de "um olho que pula do cérebro", complementa o músico Tom Zé. A essas opiniões, somam artigos, contos, falas, cursos propostos por escritores contemporâneos como Joca Terron e André Santana, instigando a curiosidade de novos leitores e, sobretudo, de pesquisadores que têm na produção artística do genial demiurgo, um instigante material de trabalho. 


\subsubsection{Uma epopeia pop}

Analisar PanAmérica significa fruir seu delírio figurativo, pilar da obliquidade no romance, observando o diálogo entre literatura e as temáticas da cultura pop, em particular, as referências de Hollywood e as da Guerra Fria. O discurso poético em PanAmérica é perpassado, temática e figurativamente, por isotopias da $7^{a}$. Arte, e suas cenas são construídas aos moldes do cinema de montagem, dotando a linguagem literária de efeitos de sentido da linguagem cinematográfica. Essa é a experimentação central da obra que apresenta enquanto atores (personagens da obra), as estrelas do cinema hollywoodiano que, literalmente, "encenam" cenas criadas e, em particular, referenciadas em filmes, mitos, livros, peças publicitárias, em permanente diálogo intertextual.

Constituída por vinte blocos, sem parágrafos, título ou numeração, a obra reúne diferentes unidades cênicas com determinada independência temática entre si. Grosso modo, e somente para fins de análise, o romance pode ser dividido em três momentos, de acordo com os programas narrativos assumidos pelo sujeito identificado pelo pronome "eu", figurativizado como (1) um cineasta onipotente em meio ao Olimpo hollywoodiano; (2) um soldado/ guerrilheiro em meio à guerra imperialista; e (3) um guerreiro em meio a deuses mitológicos e estrelas de Hollywood. Vejamos abaixo cada um desses momentos:

Entre o $1^{\circ}$ e $7^{\circ}$ bloco, o sujeito assume o papel de diretor de uma megaprodução hollywoodiana intitulada "A Bíblia". Caminhando pelos estúdios de Hollywood, cercado de atores e atrizes do cinema norte-americano das décadas de 1950 e 1960, ele realiza variados e hiperbólicos desejos da cultura capitalista, desde a compra de um Jaguar ao namoro com a atriz Marilyn Monroe. Tudo se passa dentro do Olimpo hollywoodiano, sensorial, erótico e prazeroso, de onde brotam as mitologias contemporâneas. Circulando de cenário em cenário, nós acompanhamos os bastidores e as estratégias de filmagem de diversas cenas de "A Bíblia", em plena manifestação da obliquidade, na medida em que se problematiza a artificialidade do fazer artístico, seja pela construção hiperbólica do cenário, pela onipotência exagerada desse diretor sobre os demais atores hollywoodianos, pelo nonsense resultante, por exemplo, da morte 
de vários "extras" ao longo da filmagem, constituindo o sentimento de estranhamento do mundo.

Nesse primeiro bloco, os atores da obras são revestidos de acordo com a posição que ocupam na cadeia econômica da indústria cinematográfica: no topo, estão os acionistas, produtores ou empresários do show business, caricaturas grotescas ou cômicas, apresentadas em cenas de sadismo erótico ou excessos gastronômicos; na base da pirâmide, estão os "extras" (figurantes) e trabalhadores dos estúdios (porteiros, garçons etc.), a massa despersonalizada, sempre à mercê das circunstâncias e dos caprichos dos poderosos; e no nível intermediário, está o sujeito identificado como cineasta, dando ordens às beldades de Hollywood; e vivendo um caso amoroso com "Marilyn Monroe" que será sequestrada, no final desse bloco, pelo antissujeito da obra: o atleta Joe DiMaggio.

Entre o $8^{\circ}$ e $11^{\circ}$ bloco, o Olimpo hollywoodiano desaparece e cede lugar ao cenário apocalíptico da guerra entre o Norte e o Sul. O cineasta de outrora, ainda identificado pelo pronome "eu", assume o papel de um soldado próEstados Unidos que muda de lado e mata o adido militar norte-americano, responsável pelas ditaduras no continente. Os atores, por sua vez, são revestidos em torno da cadeia econômica da guerra: no topo, os generais imperialistas; no estrato intermediário, os soldados e os guerrilheiros particularizados, bem como o sujeito e Harpo Marx, seu grande amigo; e na base dessa pirâmide, a grande massa anônima, "o povo", com seus corpos esmagados ou estraçalhados pela guerra.

Se no primeiro bloco, dá-se a construção cenográfica dos bastidores da indústria cinematográfica, propulsora da mitologia contemporânea; neste segundo bloco, dá-se a construção dos bastidores da guerra anti-imperialista, propulsora da carnificina sul-americana, em ambiente marcado pela miséria e opressão social. A inversão é total: a eufórica descrição de Hollywood e sua produção de mitos cede espaço à descrição disfórica da miséria e das violências geradas na guerra entre Norte e Sul. Aos ícones do cinema, em especial Harpo Marx, acrescem personalidades históricas, referências ao golpe de 1964 e outros episódios, Novamente, os índices de referencialidade aludem a míticas 
potencializadas pela hipérbole e pelo hipertexto. Proliferam, também, campos discursivos e isotopias figurativas relacionadas a tabus da época - sexo, virgindade, homossexualidade, pedofilia - em claro questionamento dos padrões morais e comportamentais, bem como de temas silenciados, como torturas e assassinatos, miséria e subdesenvolvimento.

A partir do $12^{\circ}$ bloco, e último conjunto da obra, tanto a temática do cinema, quanto o ambiente da guerra antimperialista adquirem conotações menos referenciais e mais míticas. DiMaggio e o sujeito entram em confronto, ao mesmo tempo, tanto Marilyn quanto DiMaggio se metamorfoseiam em outros seres. A negação do regime referencial atinge aqui o seu ápice, emulando uma espécie de Apocalipse, cujas perturbações serão sentidas e comentadas pelo sujeito, inclusive, aludindo figurativamente questões relativas à constituição do texto. O resultado é o mais completo caos finalizado pela derradeira imagem da aproximação desse sujeito, que parece cair do céu rumo à Terra.

Para compreender a construção da obliquidade em PanAmérica, nós iniciaremos a análise procurando compreender como se dão e onde incidem as práticas experimentais, observando os níveis do percurso gerativo do sentido (cf. p.23) e o plano de expressão da obra.

\section{- Considerações preliminares}

Na introdução de Caminhos da Semiótica Literária (2003), Denis Bertrand traz breve síntese sobre os estudos literários na semiótica narrativa, apontando que os semioticistas da literatura, seguindo Greimas,

(...) consideraram com reserva, e até com suspeição, todos os termos legados pela tradição literária, solidificados pelo uso e naturalizados como evidências, que filtram imperiosamente nosso acesso à textualidade: personagens, atmosfera, imagem, sentimento, descrição e narração, gêneros e estilo de escrita etc. Rejeitando, pelo menos provisoriamente, essas noções da prática descritiva, eles quiseram fazer tábula rasa para assegurar uma certa ingenuidade do olhar ou até mesmo uma suspensão metódica do julgamento (Bertrand, 2003, p.27). 
Neste sentido, a adoção do percurso gerativo do sentido como método analítico do presente corpus passa pela adoção de sua terminologia. Observando a construção do sentido, que parte de um estado de imprecisão original rumo ao de sua realização discursiva, quando personagens e temas e as relações entre os actantes narrativos apresentam-se definidos e articulados, a semiótica narrativa (ou greimasiana) define três níveis - discursivo, narrativo e fundamental -, estabelecendo uma sintaxe (relação entre os termos) e uma semântica para cada um deles. Este modelo, explica Bertrand,

\begin{abstract}
consiste em desnudar a estruturas organizadoras da nossa intuição narrativa, transformadas pela linguagem nesses 'seres de papel' que são os atores, sujeitos de desejo ou de medo, adquirindo competências, agindo, lutando, fracassando ou obtendo vitórias (2003, p.27).
\end{abstract}

Onde a obra se passa, quando e quem nos conta são informações do nível discursivo, cuja sintaxe nos permite observar os processos de actorizalização (atribuição de pessoa), temporalização (de tempo) e espacialização (de espaço). Já o revestimento figurativo e temático, ou seja, a definição dos atores e das isotopias temáticas trabalhadas na obra dizem respeito à semântica do nível discursivo. No nível narrativo, mais abstrato, não existem personagens, mas actantes, papéis temáticos exercidos pelo sujeito, objeto de valor, destinador, destinatário, antissujeito, que estabelecem relações entre si. Por fim, no nível ainda mais abstrato, o fundamental, são explicitadas tensões fundamentais que se espraiam, de modo disfórico ou eufórico, pelos demais níveis do percurso gerativo de sentido.

De modo geral, podemos afirmar que, ao logo de todo o romance, a sintaxe discursiva, onde ocorrem os fenômenos da embreagem e debreagem, será muito mais convencional do que experimental, mantendo-se praticamente uniforme. Em PanAmérica, as experimentações serão, por sua vez, muito mais incisivas em termos de semântica discursiva, onde ocorre a construção das figuras e dos temas da obra. 


\section{- Delírio figurativo}

PanAmérica é, do começo ao fim, narrada em debreagem enunciativa, ou seja, por um sujeito em primeira pessoa que instaura a relação "eu" - "tu" (narrador e narratário / enunciador e enunciatário) no discurso. Ao longo da obra, são praticamente inexistentes os diálogos diretos, na medida em que a voz dos atores é sempre enunciada pelo sujeito (também narrador) em um "agora" e um "aqui" responsáveis pelo "quando" e "onde" ocorrem os fatos elencados. Esse sujeito assumirá o papel de um "eu", em um espaço que é a mítica "PanAmérica", o continente latino-americano sem fronteiras e unido ${ }^{28}$, sonhado por Bolívar e apresentado por Agrippino, séculos depois, como campo de batalha da Guerra Fria, onde se dará o embate entre forças míticas, ideológicas, políticas e geopolíticas.

Como os atores são, em grande parte, revestidos figurativamente pelas estrelas de Hollywood - Marlon Brando, Marylin Monroe, Harpo Marx etc. -, ao serem introduzidos, eles trazem uma cadeia semiótica prévia (Barthes, 2001). Todos os traços semânticos associados ao termo "Marilyn Monroe", por exemplo, são mobilizados, e a eles se somam novos traços de sentido trazidos pela narrativa. Isso cria uma série de reimpressões, emulando, na construção da personagem, o processo de saturação da cultura do simulacro que diz respeito, também, ao descarte e à reutilização dos produtos da indústria cultural. Daí o diálogo entre Agrippino e o movimento pop. Da mesma forma que Marylin é estampada repetidamente em Untitled from Marilyn Monroe (1967), de Andy Warhol, ela também será "super" figurativizada na linguagem verbal por Agrippino de Paula.

Esse processo de saturação semântica será analisado posteriormente, agora, vale registrar que a obliquidade estará essencialmente assentada na figuratividade, um processo "que faz surgir aos olhos do leitor a 'aparência' do mundo sensível" (Bertrand, 2003, p.21).

28 O pan-americanismo foi um movimento idealizado por Simón Bolivar (1783-1830) visando a formação de um só Estado a partir de todos os territórios da América espanhola. 


\section{- Delírio narrativo}

Analisando vários contos populares, Vladimir Propp identificou em $A$ Morfologia do Conto Maravilhoso (1928) a existência de 31 actantes. Já Claude Lévi-Strauss, em Antropologia Estrutural (1958), estabeleceu uma análise não apenas sintagmática como a de Propp, mas paradigmática dos mitos, ao observar que uma mesma figura pode assumir papeis temáticos distintos em comunidades diferentes. Pode assim estabelecer uma sintaxe narrativa, percorrida por sujeitos de estado e de ação (actantes), independentemente da figurativização por eles assumida. A partir dessas e de outras bases, A.J.Greimas propôs a semiótica narrativa, desenvolvido em Semântica Estrutural (1966), Sobre o Sentido I (1970) e II (1983), e Semiótica das Paixões (1991), ensinando-nos que o sentido não é construído pelo sequenciamento de unidades cênicas, mas pelas mudanças de estado do sujeito e demais actantes narrativos, a partir das relações que eles estabelecem entre si.

É, portanto, no nível narrativo que iremos observar as mudanças de estado desse sujeito, a partir das relações estabelecidas por ele e os demais actantes da obra: sujeito e objeto de valor, sujeito e antissujeito, destinador e destinatário; e a partir de modalizações que configuram o estado (ser) e o agir (fazer) desse sujeito. Essa dinâmica relacional instaura dois tipos de enunciado: o de estado e o de ação. O enunciado de estado nos informa a sintaxe narrativa, ou seja, a relação entre o sujeito (protagonista da obra) e o objeto de valor: se eles estão em conjunção ( $(S \mathrm{O})$ ou não $(S \cap O)$. Um programa narrativo pode, por exemplo, começar pela descrição do estado de conjunção ( $S \cup O)$ entre sujeito e objeto e, de repente, essa plenitude sofrer um abalo, com a entrada do antissujeito, promovendo a ruptura do estado anterior ( $\mathrm{S} \cap \mathrm{O})$. É o que acontece nos primeiros sete blocos de PanAmérica, onde temos a construção da relação erótica-amorosa entre o sujeito ("eu") e a principal destinadora de suas ações (Marilyn Monroe), em estado de plenitude e conjunção. 
Vivendo em meio aos deuses do mass media, em verdadeiro Olimpo, esse sujeito irá fruir variados desejos ofertados pelo capitalismo graças à posição de poder que ocupa na indústria cinematográfica, desde caminhar em meio ao topless das beldades hollywoodianas até a compra de um Jaguar alado. Modalizado pelo saber-fazer e, sobretudo, pelo poder-fazer, ele é apresentado com todas as competências necessárias tanto para a filmagem de $A$ Bíblia, quanto para o convívio no Olimpo pop. Trata-se de divertida fruição do universo de sonhos vendido por Hollywood, lugar em que todos os desejos são prontamente atendidos. Isso, porém, muda com a entrada do antissujeito, figurativizado pelo atleta Joe DiMaggio que, evocando superpoderes, portanto, apresentando competências superiores às do sujeito, rapta a atriz na última cena desse bloco. É neste momento que o enunciado de estado (o "ser" modalizando o "fazer") cede lugar ao enunciado de ação (o "fazer" modalizando o "ser"), e o destinatário ("eu") se torna o sujeito da ação. A presença do antissujeito instaura o percurso de base que o sujeito terá de percorrer para adquirir competência e resgatar o objeto de valor, no caso, Marilyn Monroe.

Contudo, na sequência do sequestro de Marilyn, ocorre abrupto corte na narrativa, e o sujeito assume outro papel figurativo, agora não mais de onipotente diretor cinematográfico, mas sim de soldado na guerra imperialista do Norte contra o Sul. O cenário se transforma totalmente. O estado de conjunção e plenitude do sujeito é substituído pelo estado de disjunção e de carência, revestido pelas isotopias temáticas e figurativas do pós-Guerra, em particular os embates políticos e ideológicos da Guerra Fria.

\section{- Esquema narrativo}

Como ensina a semiótica narrativa, para entrar novamente em conjunção com o objeto de valor (ou não), o sujeito terá de passar por quatro etapas do nível narrativo: a manipulação, a aquisição de competências, a performance e a sanção. 
A primeira etapa do esquema narrativo, contrato ou manipulação, é quando um destinador convence um destinatário a se tornar sujeito, "fazendo-o fazer", ou seja, manipulando-o para que ele cumpra o plano de base da narrativa, seja a conquista ou retomada de um objeto de valor. Ele poderá manipular o querer ou dever do destinatário por meio da:

Tentação: quando o "querer fazer" do destinatário é manipulado por um poder do destinador, por meio de valores positivos. Por exemplo, "se você tomar a vacina, poderá viajar de avião";

Sedução: quando o "querer fazer" do destinatário é manipulado por um saber do destinador, a partir de uma imagem positiva desse destinatário. Por exemplo, "eu sei que você é inteligente, logo, tomará a vacina";

Intimidação: quando o "dever fazer" do destinatário é manipulado por um poder do destinador, por meio de valores negativos. Por exemplo, "se você não tomar a vacina, não poderá trabalhar aqui";

Provocação: quando o "dever fazer" do destinatário é manipulado por um saber do destinador, a partir da imagem negativa desse destinatário. Por exemplo, "eu duvido que você tenha coragem de tomar a vacina".

Em PanAmérica, várias subversões são cometidas pelo sujeito ao longo dessas etapas. O fazer do sujeito se transforma a cada percurso figurativo por ele assumido (diretor cinematográfico, soldado/guerrilheiro, herói mítico), e são todos marcados pela (1) imprevisibilidade, nunca sabemos o que ele fará ou por que o fez, impossibilitando a apreensão dos destinadores e manipulações em torno de suas ações; e pela (2) descontinuidade, na medida em que as unidades cênicas não necessariamente estabelecem uma relação de causa e efeito entre elas.

No segundo bloco, por exemplo, são muito frágeis, em termos de plano de conteúdo, as causas que explicariam a passagem do sujeito de soldado norteamericano à condição de guerrilheiro antimperialista e, sobretudo, o assassinato que ele comete contra adido militar norte-americano, responsável pelas ditaduras no continente. Poderíamos, num primeiro momento, atribuir a Harpo Marx a manipulação responsável pela reviravolta na narrativa. Surdo e mudo, a 
personagem cômico de Hollywood aparece como adjuvante do sujeito, acompanhado de uma harpa, tal qual em Uma Noite na Ópera (1935), primeiro filme dos Irmãos Marx. Harpo é, também, relacionado aos comunistas ou temáticas ligadas à luta revolucionária. A relação de amizade entre ele e o sujeito legitimaria o contrato de fidúcia (confiança), e poderíamos aventar a manipulação de Harpo sobre "eu" como da ordem da sedução na medida em que ele, com sua fragilidade, exalta o poder-fazer e o saber-fazer desse sujeito que, não raro, atribui ao surdo-mudo pensamentos que refletem suas próprias decisões. Como explica Bertrand,

A manipulação (ou o contrato) e a sanção (ou o reconhecimento), emoldurando o esquema, manifestam o percurso do Destinador. Mas ele também está presente na ação sob a forma desse antigo papel actancial, evocado mais acima, o do adjuvante, que acompanha o sujeito ao longo de suas provas como uma figura delegada do Destinador. (2003, p.301)

Neste sentido, a presença de Harpo Marx oscila muito mais como essa figura delegada do destinador, de adjuvante do sujeito da ação. Apesar de atuar como angelical influência, evocando a resistência antimperialista, Harpo é menos destinador das ações do sujeito do que os próprios índices de referencialidade lançados na obra, muito mais definidores da mudança de posição desse sujeito, como observamos no excerto abaixo:

Eu voltei para a praia e quando eu me aproximava Harpo Marx avançou furioso na minha direção com a buzina elevada e eu dei um pontapé na harpa que Harpo Marx carrega junto à barriga como escudo. Eu tentei dar um murro na boca de Harpo Marx, mas ele se desviou irado. Eu dei outro pontapé e Harpo caiu preso entre as cordas da harpa. Eu avancei para Harpo e piquei o jornal. Eu gritava para Harpo Marx que eu era contra as ideias daquele jornal e que eu não iria discutir com ele se o Partido Comunista estava agindo corretamente ou se era um erro do partido permanecer inativo e esperar a queda do governo. Eu e Harpo interrompemos a luta e sentamos novamente no tronco da árvore. (PAN, p. 106, grifos nossos) 
O trecho acima pode ser dividido em duas partes: a da pantomima, em espécie de homenagem à comédia e ao clown protagonizado por Harpo Marx, tal qual o conhecemos no universo referencial, com suas buzinas, socos, pontapés e a prisão do palhaço entre as cordas; e a reflexão política, no caso, a manifestação da raiva desse sujeito frente à decisão dos comunistas brasileiros de permanecerem inativos, esperando a queda do governo.

Sobre o episódio, aliás, ao completar 50 anos de 1964, o Partido Comunista Brasileiro (PCB) no artigo O PCB e o Golpe de 1964 (2014) explicava:

\begin{abstract}
A ação golpista encontrou tímida resistência do conjunto do movimento sindical e popular. A linha política adotada pelo PCB, que influenciava amplos setores do movimento operário, na prática desarmava a militância para o enfrentamento à onda reacionária que tomava vulto a partir da difusão da ideologia anticomunista e do discurso do "perigo vermelho" pregados pelas associações empresariais e entidades como o IPES e o IBAD, aparelhos privados da hegemonia capitalista, além dos aparatos tipicamente coercitivos, como o Exército e a Escola Superior de Guerra, o que terminou contagiando parcelas significativas das camadas médias, atraindo-as para o apoio ao golpe de 1964 (...) O PCB, ao participar ativamente da resistência contra a ditadura e mesmo corretamente não tendo aderido à luta armada - por entender que essa forma de luta não era compatível com a correlação de forças -, pagou um alto custo por essa jornada de lutas: centenas de militantes comunistas foram presos, torturados, assassinados e exilados. Antes de implementar a "abertura lenta, segura e gradual", e depois de derrotar as organizações que recorreram à luta armada, a ditadura concentrou-se numa violenta empreitada de liquidação do PCB." (PCB, 01.04.2014)
\end{abstract}

Temos, portanto, o imbricamento de episódios extraídos da conjuntura histórica e inseridos no discurso ficcional, reunindo o cinema e a literatura, o cômico e o trágico, a arte e a política, a pantomina e a violência política, afinal será a inação dos comunistas que irá mobilizar o dever-fazer do sujeito, em manipulação muito mais por intimidação do que por sedução, afinal, matar o adido norte-americano, o principal responsável pela opressão na América Latina, é um dever desse sujeito.

A segunda etapa do enunciado diz respeito à aquisição de competências. Neste quesito, a subversão em PanAmérica é total. Reforçando 
o caráter da imprevisibilidade e descontinuidade das ações do sujeito, ele não precisa adquirir competências, apenas demonstrá-las, afinal possui todas de antemão. Nos mais variados percursos de uso em que se envolve, "eu" está sempre dotado de um saber fazer e de um poder fazer prévios. Isso cria um potente sentimento de artificialidade, construindo a obliquidade desse sujeito que, aos moldes dos heróis em quadrinhos, dos filmes policiais, de guerra ou aventura, está sempre pronto para vencer o inimigo, sacando armas ou escapando por esconderijos os mais imprevisíveis possíveis, e nas mais variadas e surrealistas situações, sem nenhuma construção prévia quanto à aquisição dessas competências.

Isso não significa, porém, que inexista a aquisição de competências. Ao observarmos os três blocos da obra é possível identificarmos um primeiro momento de conjunção plena com o objeto de valor (Marilyn), um segundo de total desconjunção, e um terceiro em que os conflitos entre o sujeito e o antissujeito se acirram. Grosso modo, esse segundo bloco - em torno do assassinato do adido militar - atua como um programa de uso, explicitando a capacidade desse sujeito em enfrentar o antissujeito, dotado de poderes sobrenaturais, no terceiro bloco da obra. Como explica Greimas, o sujeito necessita do fazer (percursos de uso) para se tornar (ser) apto a realizar a performance, ou seja, a ação necessária que o levará à conjunção (ou não) com o objeto de valor.

Em PanAmérica, as competências desse sujeito, reiteradas nos planos de uso anteriores, serão colocadas à prova em sucessivos confrontos contra o antissujeito (Joe DiMaggio) e, em particular, em uma batalha derradeira, em que o atleta se manifesta sob a forma de um leão, remetendo-nos à clássica cena entre Tarzã e o leão, desdobrada nas oposições homem vs fera, cultura vs natureza que se espraiam nas referências em torno da personagem criado em 1912 por Edgar Rice Burroughts. No entanto, embora o sujeito ("eu”) vença o antissujeito (leão/DiMaggio), cumprindo a performance, ela será negativamente sancionada por dois motivos: primeiro, porque DiMaggio é imortal, e por mais que seja morto pelo sujeito, vencê-lo não significa sua eliminação; segundo, porque a vitória não significa a conjunção com o objeto de valor porque Marilyn, que também morre e retorna à narrativa, agora assume a forma de terrível deusa 
ctônica de dimensões gigantescas. O sujeito, inclusive, precisará se aliar a DiMaggio para escapar de sua fúria.

Grosso modo, podemos observar no delírio figurativo e narrativo de PanAmérica, o movimento desse sujeito, que parte de um estado de conjunção rumo ao de disjunção com o objeto de valor; e a crescente construção da ilogicidade, do nonsense, do absurdo, construindo a obliquidade. Inclusive, os aspectos "estranhos", resultantes das experimentações formais serão figurativizadas na imagem dos "blocos flutuantes", citados pelo narrador. O efeito de sentido é o de uma implosão da narrativa que começa a se desencaixar, e sobre a qual paira o sujeito, observador externo e flutuante sobre os parágrafos, frases e orações. A afirmação da liberdade é absoluta e, não à toa, neste momento de forte desagregação da narrativa, temos a presença da Estátua da Liberdade caminhando entre os blocos flutuantes, ora esmagando os seres humanos com seus passos pesados, ora os colhendo aleatoriamente para mastigá-los em uma das mais felizes críticas pop ao ethos do american dream.

\section{- Liberdade vs. Opressão}

A crítica em PanAmérica não se restringe à ditadura militar. Ela irá trabalhar, de modo completamente inovador, as figuras e temas de um momento peculiar da cultura nacional, quando o mercado doméstico se abria à indústria do entretenimento norte-americano, modalizando quereres, saberes, deveres e poderes, conforme os valores da Guerra Fria, o ideário de modernidade norteamericano, essencialmente capitalista, anticomunista e imperialista (cf. Garcia, p.30). Agrippino de Paula, por sua vez, não fará uma crítica panfletária, ele irá articular essas imagens afirmando a liberdade e negando a opressão.

Essa tensão permanente, que mobiliza o nível fundamental do percurso gerativo de sentido, é revestida de diferentes modos a cada unidade cênica. Vejamos no excerto abaixo, um desses momentos em que, após a euforia da vitória comunista nas ruas, dá-se um contragolpe capitalista. Para fins de análise dividiremos a sequência em duas partes, $A$ e $B$. 
Parte A:

O regime capitalista e as forças do governo haviam caído e os comunistas estavam no poder. Eu saltei de alegria no meio da multidão e tomei um ônibus abarrotado de camponeses. Os camponeses se apertavam uns aos outros e todos estavam alegres e cantavam. O ônibus prosseguiu lentamente pela estrada e eu desci com dificuldade, transpondo os camponeses apertados uns aos outros até chegar à porta do ônibus. Eu desci do ônibus e a multidão gritava com ódio agitando os braços para o porta-aviões "Lyndon Johnson", que atracava no cais. $\mathbf{0}$ porta-aviões levava uma multidão de fuzileiros norteamericanos em silêncio. Os milhões de capacetes imóveis cobriam toda a pista do porta-aviões. A imensa quilha de ferro se aproximava imensamente do cais enquanto a multidão que se encontrava no cais gritava furiosamente contra a aproximação do portaaviões. Eu gritei espremido na multidão irada. O portaaviões, que transportava o batalhão de marines, atracou no cais, e a multidão se dispersou em pânico. (PAN, p. 102-103, grifos nossos)

A cena constrói a invasão imperialista em PanAmérica. Ela teve como inspiração a invasão dos Estados Unidos na República Dominicana, ocorrida em 1965, o que não nos impede de evocar o imaginário da operação "Brother Sam", com destaque ao Forrestal, o porta-aviões norte-americano ${ }^{29 .}$

A cena é construída a partir de uma lente cinematográfica que trabalhará o plano panorâmico ("os milhões de capacetes imóveis cobriam toda a pista do porta-aviões") e o plano fechado ("eu desci do ônibus e a multidão gritava com

29 Como apontam James N. Green (História do Brasil - Brown University) e Abigal Jones (História - Brown University), no artigo "Reinventando a história: Lincoln Gordon e as suas múltiplas versões de 1964" (2009), "a operação secreta norte-americana, batizada de Brother Sam, era um plano de contingência concebido em 1964 para responder ao agravamento da crise política no Brasil. A operação incluía uma força-tarefa naval e abastecimento de petróleo, gasolina, e derivados, além de armas e munição para os conspiradores. Em 27 de março, Gordon alegava que essa ação dos Estados Unidos tinha como objetivo "garantir a vitória das forças amigas, mas não prestar apoio logístico ou participar militarmente da ação (...). Gordon negou que a Operação Brother Sam tivesse existido, até que a disponibilização ao público, em 1975, de inúmeros documentos da biblioteca presidencial Lyndon Baines Johnson tornou sua versão insustentável". (Green, Jones, 2009, p.67-89). Em 2014, apenas a título de curiosidade, a FSP anunciava o desmonte do Forrestal por 0,01 dólar (FSP, 07/01/2014). 
ódio agitando os braços para os porta-aviões"), e os efeitos de sentido da concentração e da difusão (parte A e parte B) dos corpos.

O que temos é a vitória comunista seguida do golpe capitalista. A massa, a qual o sujeito pertence ("saltei de alegria" / "gritei espremido"), passa do estado de euforia para o de disforia. E temos o jogo de oposições - liberdade vs. opressão - figurativizado em isotopias da liberdade, representada pela multidão dos corpos humanos que se emocionam e se esmagam; e isotopias da opressão, representada pela multidão metálica, revestida pelo maquinário da guerra ("milhões de capacetes imóveis", "imensa quilha de ferro", "porta-aviões") que avança contra os corpos desprotegidos. Essa oposição também pode ser desdobrada em homem vs. máquina, construindo a superioridade militar dos invasores frente a fragilidade dos corpos, além de vários outros pares opostos que reforçam a desigualdade de forças: ônibus/porta-aviões, gritos da multidão/silêncio dos soldados, emotividade da massa/frieza do Exército, multidão em pânico e dispersa /batalhão de marines concentrada.

Essas figuras se alternam e quando o confronto parece iminente, ele é suprimido da narrativa, e temos a passagem brusca para nova unidade cênica que marca o pós-confronto:

Parte B:

Eu balancei os pés sentado na longa mesa de mármore do frigorífico e olhei para as altas e volumosas cabeças dos comunistas que tinham sido enforcados depois da invasão dos marines. De capacete de aço, farda e metralhadora eu montava guarda no frigorífico sentado na laje de mármore e os meus pés estavam soltos no ar. Entrou uma estudante comunista com uma máscara contra gases, e recolheu um dos corpos decapitados que se encontrava num saco de trigo. Eu percebia o volume e o peso do corpo encerrado no saco de trigo. A estudante comunista arrastou o saco com dificuldade, parou à minha frente e perguntou como que eu conseguia permanecer indiferente ao que estava acontecendo. Eu olhei para as cabeças dos comunistas conservadas nos frigoríficos enquanto eu balançava os pés soltos no ar. Eu olhei para as cabeças dos comunistas conservadas no frigorífico do Departamento de Ordem Política e Social, e as cabeças eram muito grandes e lembravam cabeças de papelão pintado usadas no carnaval. Os olhos estavam abertos e a língua para fora, e havia uma 
outra língua comprida e fina amarrada ao pescoço da enorme cabeça como uma gravata (PAN, p. 102-103, grifos nossos)

Nesta segunda parte, o cenário é de pós-guerra, sugerindo a carnificina. O ambiente é desolador e seus elementos mais e mais distantes da referencialidade. Sobre uma laje de mármore, o sujeito monta guarda de cadáveres dos comunistas enforcados. A concentração figurativa de outrora (corpos vivos, quentes, alegres e corpos metálicos, frios, silenciosos) é substituída pela difusão dos corpos resfriados, sem vida; e, sobretudo, desse corpo arrastado pela jovem comunista. Além disso, os responsáveis pela matança são nomeados: "eu olhei para as cabeças dos comunistas conservadas no frigorífico do Departamento de Ordem Política e Social”, em aberta denúncia.

De modo geral, podemos observar na parte $A$, o predomínio da lente panorâmica e da concentração figurativa, que nos permite observar a passagem da massa, em meio à euforia de um poder- fazer (liberdade) para o não-poderfazer (impotência). Na parte B, predomina o plano fechado. A multidão corpórea e viva de outrora é sucedida pelo corpo dentro do saco de trigo. O calor é substituído pelo frio, o grito pelo silêncio, o coletivo por três personagens (narrador, moça e cadáver); a vida pela morte. Quanto ao sujeito, ele passa da concentração corpórea (espremido entre a massa) para a difusão sem vida, do maquinário de guerra (capacete de aço, farda e metralhadora). Esse jogo de oposições é finalizado com o questionamento, sem meias palavras, da jovem que pergunta ao sujeito, como ele consegue permanecer indiferente ao que estava acontecendo, reiterando a denúncia contra a ditadura na obra.

O excerto acima - e de certa forma, todas as obras aqui analisadas desmentem os que alimentam o preconceito frente ao experimental, taxando-o alienado ou restrito a questões formais. A partir de fatos da contemporaneidade da obra, é possível acompanharmos várias unidades cênicas como esta que através de seu delírio figurativo imprimem a crítica contra a opressão, abordando as violações aos direitos humanos cometidas naquele momento. 


\subsubsection{Entre o referencial e o mítico}

Em PanAmérica, os índices de referencialidade estão por todos os lados: o espaço e cenário da narrativa correspondem a lugares e cenários reais, a objetos da indústria de consumo e, sobretudo, às marcas da cultura pop. Ao mesmo tempo, seus atores são revestidos pelas estrelas de Hollywood e as unidades cênicas, não raro, dizem respeito a episódios da realidade da obra, como o casamento entre Marilyn e DiMaggio, por exemplo. Vejamos, primeiramente, como a referencialidade é construída:

Quando eu cheguei ao aeroporto, eu ainda estava tomado pela minha própria inércia e pelo ruído uniforme do motor. Atravessei a multidão e os bares do aeroporto, entrei na praça e tomei um táxi. Trinta minutos depois eu estava em Hollywood e entrava no estúdio F. Burt Lancaster estava sentado na mesma cadeira em que ele estivera sentado três meses antes. Eu conversei com Burt, e Burt perguntou por Sinatra, e eu respondi que Frank Sinatra estava bebendo muito, e quando não bebia passava os sábados e domingos dormindo. O iluminador se aproximou e disse que naquele dia a filmagem terminaria mais cedo. Os acionistas de Hollywood iriam se reunir ali no amplo estúdio de filmagem (...). (PAN, p. 33).

O encadeamento de ações construídas acima dá-se em total consonância com a referencialidade, em que se notam os conectores de temporalidade (três meses antes), a ambientação do estúdio, o diálogo cotidiano e banal entre colegas, e outras ações da vida cotidiana. Burt Lancaster, Sinatra e o próprio sujeito são apresentados conforme o papel que encarnam na indústria cinematográfica e suas características não extrapolam características de homens comuns, profissionais da indústria do cinema. Essa perspectiva referencial, no entanto, irá se justapor à perspectiva mítica e hiperbólica, em um processo de negação da referencialidade e de afirmação do regime mítico. Em geral, isso ocorre quando se dão os embates entre sujeito e antissujeito, responsável pela introdução do caos, do diabólico, da violência na narrativa. Abaixo, um breve excerto desse ambiente mítico trazido pelo antissujeito o surgimento desse actante, no sétimo bloco da obra: 
As trombetas e os tambores tocaram e apareceu no túnel Joe DiMaggio sendo levado num palanque por dez negros eunucos de saiote dourado. A multidão se levantou e todos cantaram o hino da chegada de DiMaggio. O herói DiMaggio, de capacete dourado, brilhava ao sol e o atleta agitou sua foice de prata e a sua capa de seda vermelha. DiMaggio mantinha a cabeça elevada e era levado sobre o palanque por dez negros eunucos. DiMaggio abaixou a foice de prata e as trombetas e os tambores cessaram e em seguida a multidão finalizou o hino e deu um hurra! (PAN, p. 84).

A entrada desse ser mítico - e assim ele permanecerá, com raras exceções ao longo da obra - inicia-se com a construção rítmica, no plano de expressão, da dança ritual; por meio da aliteração (trombetas/ tambores/ tocaram), da repetição que emula a circularidade própria dos rituais festivos (trombetas e os tambores tocaram/ trombetas e tambores cessaram, multidão se levantou/ multidão finalizou e deu um hurra!), e da gradação marcada pela hipérbole na construção do delírio figurativo no plano de conteúdo. Ao signo Joe DiMaggio, estrela dos Yankees e ex-marido de Marilyn Monroe, inconteste ícone da virilidade norte-americana, são somados os atributos míticos, das forças demoníacas e caóticas, como indicam o capacete dourado, a foice de prata e a capa de seda vermelha.

Comparando os dois excertos acima, é possível observar que no primeiro, referencial, a narrativa se aproxima ao registro objetivo, calcada nos verbos de ação do sujeito e na construção de cenário próximo às imagens do mundo. Já no excerto mítico, a descrição é o próprio ritual de entrada do herói na narrativa, a partir de recursos poéticos da linguagem verbal. Ambos ocorrem no cenário de Hollywood, em ambiente propício à alternância entre as dimensões referencial e mítica, revelando o ambiente próprio da obliquidade, pela qual, o regime referencial é negado e o mítico afirmado, porém, a mítica nunca será completa, afinal, por mais diabólico que seja, Joe DiMaggio está ancorado à força do signo que carrega, enquanto atleta e ex-marido de Marilyn Monroe. 


\section{- Denúncia da artificialidade}

Além da presença desses dois regimes ao longo de toda a narrativa, um outro aspecto central à construção da obliquidade em PanAmérica é a presença de índices que apontam a artificialidade de sua construção. Como destaca Pietroforte, além dos efeitos de sentido de referencialização, responsáveis por fazer as linguagens parecerem "decalques da realidade", existem efeitos responsáveis por revelar as linguagens enquanto construções semióticas:

Os discursos artísticos, por explicitar em suas práxis a construção de mundos possíveis, terminam por revelar os princípios construtivos dos sistemas semióticos em que se realizam. Alguns fazem isso com mais intensidade debruçandose justamente sobre esses princípios, tematizando-os explicitamente em suas produções textuais (Pietroforte, 2016, p. 125).

Em PanAmérica, os princípios construtivos dos sistemas semióticos não são apenas explicitados na obra, mas revestidos figurativamente, como vimos na imagem dos "blocos flutuantes", e veremos abaixo na construção figurativa de um "ovo cósmico" que surge, de modo completamente aleatório (da mesma forma como as competências do sujeito são lançadas na narrativa), no terceiro conjunto de blocos da obra, enquanto explicação sobre as "perturbações" crescentes da narrativa:

Eu pensei que aquelas perturbações poderiam ter origem no ovo frito cósmico. Nós três vimos milhares de minúsculas cabeças na multidão sendo iluminadas por uma luz branca e todos olhavam em pânico para cima do prédio em que nós estávamos. Eu disse para Burt que o ovo frito cósmico, semelhante a uma galáxia, deveria estar passando e que a multidão apontava para o ovo frito cósmico, que irradiava uma luz branca e produzia um som grave e que aumentava. Eu, Burt Lancaster e o policial do Departamento de Ordem Política e Social procurávamos nos estender na janela e olhar para cima; mas o ovo frito cósmico passava atrás do prédio em que nós estávamos e nós só vimos uma parte da luminosidade branca que deveria ser a clara do ovo frito cósmico (PAN, p.243) 
Sobrevoando os céus dessa PanAmérica, a imagem de um ovo cósmico será lançado (e não construído) como explicação sobre as perturbações da narrativa, evidentemente, uma explicação insustentável. Ele aponta para o actante destinador transcendente, responsável pelo agir não apenas do sujeito, mas de todos os actantes e acontecimentos da narrativa, em tentativa de conferir sentido à crescente ilogicidade da obra. Atua, portanto, na reiteração da obliquidade da narrativa, expressando as limitações desse sujeito. Além disso, em PanAmérica, o mítico "ovo cósmico" é reconfigurado a partir da leitura pop: trata-se de um "ovo cósmico frito".

A partir daí, as figuras e temas da narrativa vão se desfragmentando, como podemos observar abaixo:

O grande incêndio de Napalm atingiu os últimos ocupantes do bloco flutuante formado por cães e Karl Marx ao longe e era coberto por uma nuvem de fogo. Os dois blocos se encontraram e partiram em quatro pequenos blocos formados de motocicletas, porta-aviões, bicicletas, máquinas de lavar roupa, flechas e espadas (...) Eu olhei para o grande bloco de violinos, do presidente Kennedy, do primeiro-ministro De Gaulle, de Hitler e do reverendo Luther King deslizando através dos outros blocos flutuantes que avançavam para a frente, e esse bloco se imobilizou e passaram flutuando no espaço homens, mulheres, animais, pássaros e peixes (PAN, p.258, grifos nossos).

Organizadas em "blocos flutuantes" e assim enunciadas, as isotopias figurativas anteriormente trabalhadas em unidades cênicas se encontram flutuando em blocos à deriva no texto. A metalinguística é acionada: os vários discursos flutuam, chocando-se e gerando novos blocos mais fragmentados. Não se trata mais de descontinuidades promovidas pela ação de antissujeito sobre o sujeito, mas de destroços de uma narrativa que metaforiza, em sua tentativa de representação do caos, o espaço primordial que antecede a criação da obra artística. De modo não menos oblíquo, a obra denuncia sua construção ficcional, metaforizando o caos primordial da criação artística. 


\subsubsection{O cinema "verbal" de Agrippino}

Inscrita em estrutura que privilegia a descontinuidade e a interdependência de suas unidades cênicas, PanAmérica irá construir sua obliquidade mantendo estreita correlação entre seus planos de expressão e de conteúdo. Isso ocorrerá, a partir de três procedimentos experimentais principais: a fusão de sistemas semiológicos; a saturação semântica dos personagens, o estabelecimento de relações transtextuais, em particular, a hipertextualidade.

\section{- Fusão de sistemas semióticos}

Da mesma forma que a linguagem literária se estrutura pelo encadeamento das orações, a linguagem cinematográfica se constrói pelo encadeamento de vários fotogramas ou fragmentos que constituem um filme. Como explicam Jacques Aumont e Michel Marie no Dicionário teórico e crítico de cinema (2013), os vários tipos de montagem cinematográfica giram em torno da continuidade ou descontinuidade da narrativa, garantindo menor ou maior visibilidade das mudanças nos planos cinematográficos.

Entre as técnicas de montagem, algumas buscam um "cinema de transparência", como o raccord que consiste no corte comum entre as cenas, sem efeitos de transição, utilizado e aperfeiçoado pelo cinema hollywoodiano, e que tem como objetivo apagar as mudanças de plano, garantindo a "continuidade da narrativa visual" (Aumont; Marie, 2013, p. 136). Há também o plano sequência, como o próprio termo indica "um plano bastante longo e articulado para representar o equivalente de uma sequência" cinematográfica (ibidem, p. 231), como podemos apreciar em Terra em Transe (1967), de Glauber Rocha, um dos maiores expoentes da utilização dessa técnica no país. Além desse cinema que busca a transparência, existe um outro que prima pela valorização da descontinuidade e das sucessões dos planos cinematográficos como 0 cinema de montagem praticado em O Encouraçado Potemkin (1925) de Serguei M. Eisenstein que concebia o filme como um 
sistema coerente de fragmentos, mais exatamente, um sistema de sistemas, que atravessa todos os fragmentos, cada um dos sistemas parciais - a cor, o som, o contraste preto/branco, a dimensão de plano etc. - devendo ser, precisamente, determinado para levar ao sentido do conjunto (ibidem, p. 136).

Cineasta de filmes experimentais, influenciado pela técnica de montagem, como vemos em Hitler, Terceiro Mundo (1968), Agrippino de Paula dialoga em PanAmérica com essa visão de cinema, euforizando a descontinuidade e a estética do fragmento.

A partir desse diapasão, podemos observar PanAmérica como um conjunto de peças de um maquinário coeso. Escrita sem parágrafos e dividida em 20 blocos, sem nome ou numeração de capítulos, a obra é composta por unidades cênicas que irão manter relativa interdependência temática, encontrando-se, aos moldes do cinema de montagem, justapostas no discurso poético. Trata-se, portanto, da junção de takes que simula a construção cinematográfica, possibilitando a confluência de várias isotopias figurativas e campos discursivos (em confronto, aliança ou neutralidade) justapostos sem qualquer relação hierárquica e protagonizados por personagens planas.

Essa interdependência entre as cenas-se espraia no nível transfrástico, como podemos observar no excerto abaixo, que detalha a compra de um Jaguar pelo sujeito:

Eu voltei e passei na frente da loja de automóveis e vi através do vidro um Jaguar esporte. Era um Jaguar esporte de cor preta. Eu entrei, e logo o vendedor sorriu para mim saindo do fundo da loja. 0 Jaguar estava envolto num papel celofane e uma fita vermelha larga e brilhante prendia a frente e formava um laço sobre a capota de lona. O Jaguar era conversível. Eu contornei o carro e o vendedor emitiu uma primeira sílaba e eu fiz um gesto para que ele se calasse e fui obedecido prontamente. Eu contornava em silêncio o motor alongado e os dois assentos forrados de couro preto. Eu fiz um sinal para o vendedor e disse: "É este mesmo". O vendedor perguntou se eu desejava que se retirasse o papel celofane, e em 
seguida me conduziu para o balcão onde eu assinei o cheque. $\mathbf{O}$ vendedor retornou para perto do Jaguar e continuou gesticulando e dizendo a respeito das perfeições do carro. Eu disse: "Pode desembrulhar". 0 vendedor se atrapalhou um pouco com a minha ordem, mas imediatamente passou a retirar o celofane que envolvia o carro. 0 vendedor retirou o celofane, em seguida, puxou a fita vermelha e abriu a porta (PAN, p. 3738, grifos nossos).

PanAmérica é inteiramente construída a partir de três procedimentos experimentais observáveis no trecho acima:

(1) O uso de orações curtas e dispostas de forma paratática 30 no nível transfrástico, obedecendo a forma sujeito + verbo + objeto $(S+V+O)$ : "Eu voltei e passei na frente... / Eu entrei, e logo um vendedor.../ Eu contornei o carro.../ Eu fiz sinal..."”;

(2) O uso de orações simples ou compostas a partir do polissíndeto, majoritariamente a conjunção aditiva "e", no nível frástico, obedecendo a forma $\mathrm{S}+\mathrm{V}+\mathrm{O}$ : "Eu voltei e passei (...) e vi (...)";

(3) O uso da repetição contínua do sujeito da ação (em negrito no excerto) - "eu", "Jaguar", "vendedor" - no início de cada período.

Esses procedimentos nos níveis frástico e transfrástico, marcados pela repetição do sujeito da ação, denotam relativa independência entre as orações que, por sua vez, irão compor unidades cênicas também dotadas de relativa independência que, por sua vez, irão compor os blocos da narrativa. Essa estrutura cria o efeito da parataxe no plano de expressão, sustentando, com elegância e simplicidade, uma vertiginosa profusão de isotopias figurativas.

Podemos, portanto, relacionar o efeito da parataxe, exaustivamente utilizado em PanAmérica, à técnica do cinema de montagem, em que cada oração à semelhança de cada take confere efeito contínuo da sucessão

30 Parataxe é a justaposição de orações sem a presença de conjunções coordenativas ou subjuntivas. Nos limites da frase, evidentemente, podemos identificar a hipotaxe interligando orações simples a partir da iteração do assíndeto. Porém, em perspectiva transfrástica, a partir da qual se dá a presente análise, cada uma dessas orações é coordenada de forma paratática criando o efeito de montagem ao longo da obra. 
cinematográfica. Esses dois procedimentos irão euforizar a descontinuidade narrativa, ou seja, irão marcar o "corte entre os planos", chamando nossa atenção para o processo de criação da obra de arte, e nos ensinando a ler a obra a partir dessas descontinuidades. Em termos de semântica global, a relativa independência das orações, garantida pela identificação do sujeito de ação em cada período, reflete-se na independência das unidades cênicas que, naturalmente, converte-se em interdependência quando se considera a coesão dessas unidades, justapostas de forma análoga ao plano montagem.

Da mesma forma, a construção fragmentada sustenta a crescente obliquidade temática, conforme avança a ilogicidade da narrativa, permitindo a profusão de vários programas narrativos, fundamentais ao jogo transtextual, capaz de encenar os mais variados textos, bem como cenas de filmes (aventura, terror, policial, desenho) ou de outras obras artísticas. Como podemos observar abaixo, um excerto referente à compra de um Jaguar pelo sujeito.

Eu entrei no Jaguar, sentei-me e coloquei as mãos sobre a direção. O painel era preto, os ponteiros brilhavam marcando a velocidade. Eu verifiquei pelo ponteiro se o tanque estava cheio, e o vendedor entregou-me a chave, eu introduzi a chave e liguei o motor. O motor roncou alto e o vendedor afastou-se alguns passos colocando as mãos sobre os ouvidos. Um outro funcionário da casa cobria as duas portas de vidro. Eu apertei o acelerador, controlei o câmbio e manobrei o Jaguar para fora da loja. Entrei na avenida suavemente, apertei o botão e a capota conversível se abriu encolhendo para trás. Eu acelerei o Jaguar e percorri a avenida, dobrei a esquina e entrei numa rua mais movimentada. Os carros passavam ao meu lado, e alguns motoristas comentavam sobre o meu Jaguar com outras pessoas. Alguns transeuntes que estacaram ao sinal vermelho permaneceram em silêncio olhando com espanto para o meu Jaguar. O sinal vermelho trocou para o verde e eu acelerei o Jaguar provocando um ruído grave e ritmado. O Jaguar contornou os carros e eu passei por um ônibus (PAN, p. 38).

Nota-se, acima, a justaposição de cada take por meio de detalhamento extremo das ações do protagonista, dispostas gradativamente e em sequência, permitindo (1) a posse da máquina pelo homem, por meio do detalhamento dos verbos - entrar, sentar, colocar as mãos, introduzir a chave, ligar o motor etc. - 
com a utilização da hipérbole e da sugestão sinestésica, afinal, trata-se de um ronco tão alto e ameaçador que um funcionário é obrigado a cobrir as duas portas de vidro; (2) a posse do homem pela máquina, por meio do prazer da compra ("ponteiros brilhavam", "ronco alto", "capota conversível") e da ostentação do objeto de valor que acresce status e visibilidade ao sujeito, firmando sua posição acima dos motoristas que possuem apenas carros e comentam e dos transeuntes que andam a pé e se espantam, incluindo na mesma isotopia social a menção ao ônibus.

O deleite do consumo é oferecido sob a forma de um discurso que acopla à narrativa literária o discurso da publicidade, calcado na adjetivação exclusiva do Jaguar, sonho de consumo da época; e na ausência de diálogos entre o sujeito e o vendedor. Podemos pinçar neste excerto, vários slogans: Jaguar esporte de cor preta, conversível, capota de lona, motor alongado, dois assentos forrados de couro preto; envolvido em papel celofane com fita vermelha larga e brilhante. Apresentado (e vendido) como inegável objeto de valor. Diante do Jaguar o sujeito protagoniza um duplo papel: é sujeito no discurso literário e destinador no discurso publicitário na medida em que atua sobre o querer-fazer desse leitor, a quem a peça publicitária é dirigida.

\section{- Lente cinematográfica}

Outro aspecto trabalhado na narrativa, também constitutivo da fusão entre literatura e cinema, diz respeito ao modo como a enunciação promove aproximações e distanciamentos, emulando o movimento da câmera cinematográfica. O trecho abaixo que sucede longo interlúdio afetivo e sexual entre o sujeito e a então destinadora de suas ações, a atriz Marilyn Monroe, exemplifica esse movimento:

A minha cabeça estava inclinada e eu via o rochedo como uma enorme massa de carne imóvel se introduzindo na água do mar. A espuma branca explodia para o alto e salpicava de pequenas gotas o dorso imenso de pedra. A água corria entre as pedras e se distribuía entre os vãos, 
e escorria fervendo para o mar. A imensa massa líquida verde continuava enviando lentamente a série de pesadas ondas que se aproximavam do rochedo. Eu olhava para as pedras, que pareciam ter uma consistência pastosa e pareciam ter sido jogadas do alto. Depois o rosto de Marilyn Monroe estava muito próximo do meu e a pele branca irradiava a luminosidade do sol. Eu vi muito próximo dos meus olhos o nariz, a boca, os dentes, os olhos, os pelos da sobrancelha e os poros. O rosto era recortado pela luz azul e brilhante do céu. Ela movimentou a boca lentamente e eu vi os dentes aparecendo, a língua e depois os lábios se fecharam. Eu sentia a mesma desproporção da natureza, e o rosto de Marilyn Monroe iluminado pelo azul do céu, e eu via as dimensões gigantescas da boca, do nariz e dos olhos fechados (PAN, p. 67).

A cena acima é construída em dois planos: o panorâmico e o fechado.

No plano panorâmico, a natureza é antropomorfizada e a narrativa erotizada, sugerindo o ato sexual. O desejo do sujeito "carnaliza" as forças da natureza transformando a paisagem: "rochedo" / "massa de carne", "espuma branca explodindo"/ orgasmo, "dorso da pedra"/corpo de Marilyn, "pedras pastosas", "água", "vãos". No plano fechado, Marilyn surge com proporções gigantescas 31 e sobre ela incidem as forças da natureza, construída pelo jogo de luz, "pele branca", "luminosidade do sol", "luz azul e brilhante do céu", "iluminado pelo azul do céu"; e pelo jogo prosódico, constituído pela iteração de termos e de partes do corpo da atriz - "nariz, boca, dentes, olhos, pelos da sobrancelha e os poros" e "boca, nariz, olhos fechados". Ambos atuam na construção de um imenso close-up do rosto de Marilyn, evocando uma gigantesca tela de cinema.

Da mesma forma, as partes da natureza transformadas em corpo e as do corpo transformadas em natureza expressam a totalidade homem-natureza, em uma narrativa que introduz na enunciação o ir e vir da câmera (distanciamento, corte), reiterando a simbiose de um sistema híbrido entre literatura e cinema.

31 Trata-se de um plano fechado muito próximo do obsessivo olhar da Nouvelle Vague (vide Anna Karina em Une femme est une femme de Jean Luc Godard). Curiosamente, movimento cinematográfico do qual José Agrippino era fortemente crítico. 
Vale salientar que essa "estética do fragmento" ao mesmo tempo em que afirma a descontinuidade (das orações, unidades cênicas, blocos), confere ritmo (iterações, assonâncias, aliterações) e distintos planos descritivos (panorâmicos ou fechados) na construção da isotopia cinematográfica, reafirmada pela parataxe e pelo mover dessa câmera essencialmente cinematográfica.

\section{- Saturação semântica e cultura do simulacro}

Outra característica que além de corroborar o sincretismo entre a linguagem cinematográfica e a literária, ajuda-nos a compreender a construção da obliquidade, é o fato de os atores sofrerem forte processo de saturação semântica. Apresentados qual avatares, eles sofrem um contínuo descolamento figurativo. Vários se transmutam em outros seres, enquanto o sujeito assume distintos programas narrativos, sem prejuízo à coesão textual. Isso somente é possível devido à ausência de digressões, expectativas ou motivações psicológicas do sujeito e dos demais atores, o que não significa inexistência de subjetividade, como pudemos observar na erotização da paisagem do último excerto.

Em PanAmérica, os personagens da obra são, em grande maioria, representantes do mass media (atores de Hollywood, personagens de desenho, personalidades históricas e até mesmo objetos), ou seja, eles são inseridos na narrativa dentro de uma cadeia semiótica prévia aos acontecimentos da obra. Como explica Roland Barthes, em Mitologias (1957):

o mito é um sistema particular, visto que ele se constrói a partir de uma cadeia semiótica que existe já antes dele: é um sistema semiológico segundo. O que é signo (isto é, totalidade associativa de um conceito e de uma imagem) no primeiro sistema, transforma-se em simples significante no segundo" (Barthes, 2001, p. 136)

Constituídos a partir de uma cadeia semiológica prévia, ao serem inseridos, os mitos hollywoodianos deslocam a consciência significante do leitor, 
capturado pelo engajamento proposto, em um jogo bem-humorado, que o permite fruir a "imortalidade" e o "cotidiano" dos novos deuses da sociedade de massas. Segundo Barthes, a significação dos mitos, à semelhança de um torniquete incessante, alterna o sentido do significante: "a forma permanece vazia, mas presente, o sentido ausente e, no entanto, pleno" (ibidem, p. 145).

Esse estado de esvaziamento e de plenitude é fruto da saturação semântica dos atores da narrativa, colocados para encenar os mais variados papeis ao longo da obra. Esse aspecto, consequência do fato de eles serem todos ícones de Hollywood, traz dois efeitos de sentido: a artificialidade da obra de arte, reforçando aqui a obliquidade; e a natureza do simulacro da cultura contemporânea, na medida em que tudo é reimpresso, inclusive, o sujeito da obra, continuamente repetido, em uma profusão de "eus" ao longo das 300 páginas do livro.

A saturação é intensificada em termos narrativos pelo fato de o sujeito (narrador-personagem) se mover e realizar performances, sem passar pela aquisição de competência, como vimos anteriormente. Característica que o aproxima dos personagens de desenhos animados e filmes de ação: do nada, ele saca sua arma e ataca o inimigo, pula em vagões em movimentos que surgem repentinamente, caminha por corredores que se abrem num passe de mágica. Algo, insistimos, possibilitado pela recusa de qualquer digressão ou julgamento moral dos personagens, dotando a narrativa de intensa e corrosiva objetividade.

Em termos de plano de expressão, a saturação é constituída a partir de dois procedimentos experimentais:

(1) A iteração pronominal que reforça o sentimento de artificialidade do texto, promovendo a multiplicação infinita do sujeito ou demais actantes, ao longo de toda a obra. O pronome "eu", por exemplo, aparece em cada oração, no início ou em seu interior, não raro, repetido dentro de um mesmo período, o mesmo ocorre com os demais personagens. O sentimento, por conta da iteração, é de verdadeiro esvaziamento figurativo do actante, promovido pela própria exaustão do termo. Ao mesmo tempo, a iteração mantém a coerência da 
enunciação: operando como a constante em que o enunciatário pode se apoiar conforme avança a obliquidade e ilogicidade narrativa.

(2) A ausência dos operadores argumentativos ("mas", "pois", "porque", "apesar") em contraposição à proliferação dos conectores aditivos, operando a ligação das orações compostas. O que é fundamental para o encadeamento das mais diferentes isotopias figurativas, todas ordenadas de forma aditiva e enunciadas a partir de um distanciamento ou aproximação que simula o olhar cinematográfico. A predominância de conectores aditivos, sobretudo a conjunção aditiva "e", permite o encadeamento de vários campos discursivos, em processo de adição contínua que alude à estrutura das narrativas épicas e culmina, em termos figurativos, na exaustão do próprio processo narrativo como se a somatória dos contextos implodisse os limites do texto, conforme metaforizado nos "blocos flutuantes" no final da obra.

Esses dois aspectos - iteração pronominal e ausência de conectores argumentativos - também aludem ao processo serial da produção industrial de mercadorias (culturais ou não) reforçando o efeito de saturação semântica, tanto pelo excesso de repetição quanto pela somatória frenética das isotopias figurativas. O plano da expressão materializa, assim, aspectos essenciais à apreensão dos campos discursivos trabalhados pela enunciação.

Como destaca Hoisel, em "PanAmérica: uma cartografia dos processos de globalização nos anos de 1960" (2008):

O texto de PanAmérica não se constrói seguindo os padrões tradicionais da representação, mas se configura como um simulacro: cópia de cópia. Não é a realidade imediata que lhe fornece o seu conteúdo - as relações e os sentimentos humanos, os conflitos íntimos dos personagens -, porém, uma realidade secundária: a imagem de um ídolo de massa, um clichê (...) a história, ou melhor, os fragmentos de história são montados a partir de um eu narrador que se repete insistentemente, obsessivamente, através de um processo de colagem que evidencia a superficialidade e o achatamento dos acontecimentos narrados e do sujeito que se dispersa ao longo da narrativa. Nesse sentido, como texto paradigmático da cultura do simulacro, PanAmérica encontra nessa superficialidade um dos componentes principais do processo de construção, deslocando o modelo da profundidade narrativa da primeira 
metade do século 20. (ibidem, p.30)

Em PanAmérica não é preciso teorizar sobre o simulacro na sociedade moderna, na medida em que sua construção é a própria reiteração do processo de falsificação promovido pela indústria cultural. Assim como as latas de sopa Campbell de Andy Warhol, o narrador de PanAmérica é estampado em série e em profusão. Nisso consiste a força e a radicalidade de sua experimentação: a crítica se imprime no modo de sua enunciação, conforme a correlação entre os planos de expressão e de conteúdo.

\section{- Diálogo intertextual}

Ao considerar que a produção literária trabalha muito mais com o já dito do que em criar algo do nada, Maingueneau observa que "cada obra, cada gênero define sua identidade por sua maneira de gerar a transtextualidade" (1996, p.27), em particular, a hipertextualidade, composta por "relações que unem um texto que se enxerta num texto anterior, por transformação ou imitação" (ibidem). O trecho abaixo, que sucede à compra do Jaguar analisada anteriormente, permite-nos acompanhar como a hipertextualidade opera na narrativa:

Eu apertei novamente o acelerador até o fundo e as árvores passavam velozes ao meu lado e eu via a estrada desaparecer sob as rodas do Jaguar. Eu continuei acelerando o Jaguar e o motor zunia transpondo as curvas. O Jaguar veloz saltou com um estrondo para fora da murada e eu vi o mar sob as rodas. $O$ Jaguar continuou deslizando e eu vi longas asas brancas saindo das duas portas, e o rufar das batidas ritmadas e lentas das asas brancas. Eu vi as vagas no seu movimento e as amplas asas do Jaguar permanecerem retas e horizontais e o carro planar alguns instantes e logo em seguida realizar uma curva. Eu voltei na direção da estrada que eu havia passado e vi a alguns metros abaixo Marilyn descendo a avenida junto à murada. Eu acenei para ela e ela parou alguns instantes olhando para o céu, onde eu estava sendo levado pelo meu Jaguar alado. As amplas asas batiam ao meu lado e eu prosseguia olhando a praia lá embaixo, as janelas minúsculas dos edifícios, as ruas e as avenidas (PAN, p.39). 
Finalizando o percurso da narrativa publicitária temos a construção de uma imagem hiperbólica que sintetiza a potencialidade máxima do Jaguar: a transmutação do carro em uma espécie de Pégaso, construída de forma sinestésica, a partir da:

(1) simulação do movimento da câmara cinematográfica na linguagem verbal: muda-se o plano de observação dos elementos anteriormente narrados a partir da inserção de marcadores da distância entre os planos (lá embaixo/ janelas minúsculas);

(2) da cadência rítmica simulando o bater das asas: pela repetição do termo "asas" (asas brancas, amplas asas) e do verbo ver; pelas aliterações e assonâncias (rufar das batidas ritmadas e lentas das asas brancas / eu acenei para ela e ela parou / sendo levado pelo meu Jaguar alado); e pelo uso do gerúndio.

Em termos de organização figurativa se dá a inserção de características animadas ao Jaguar por meio da justaposição de substantivos inanimados (portas, rodas) e animados (asas brancas) e de verbos que indicam características animadas do carro (zunia, saltou, rufar das asas). O programa de uso parte, portanto, de um discurso referencial (a compra de um carro) e chega ao discurso mítico (a transformação do Jaguar em Pégaso), expressando de forma sinestésica (a sensação do voo) a potência máxima e hiperbólica do objeto de valor (o Jaguar alado).

Temos o ápice das duas interações imbricadas na narrativa entre o sujeito e o objeto de valor no percurso ficcional da obra; e o enunciador e o coenunciador no percurso da peça publicitária. Assim como Marilyn, o Jaguar, ícone da sociedade de consumo, sofre um deslocamento do signo: o objeto de consumo (mito contemporâneo) é potencializado sob a forma Jaguar alado (mito grego).

Opera-se, assim, a hipertextualidade na fusão da ficção literária/peça publicitária à mitologia no interior da narrativa. Ao mesmo tempo, em termos semânticos, a hipérbole mítica rompe, sob a forma do pastiche, com as coerções do discurso publicitário. O slogan do mercado se revela: adquira um Jaguar e 
será possível obter status social, mulher e até mesmo voar. A construção narrativa incide, portanto, enquanto dessacralização do mito contemporâneo a partir da dupla mitificação: ao do Jaguar, símbolo de poder na sociedade capitalista, é acrescido o campo semântico do mito do Pégaso, símbolo de poder no mundo antigo.

A onipotência do narrador-personagem - construída nesse primeiro bloco da obra - é reafirmada de forma coesa. Várias isotopias temáticas do gênero épico são emuladas ao longo do excerto, a construção cênica da anábase, a subida ao Monte Olimpo; ou em outras partes da narrativa, inclusive, a queda dos céus que encerra o romance. Além disso, os personagens se transmutam em seres míticos, promovendo uma dupla mitificação: aos mitos contemporâneos são acrescidos mitos do mundo antigo. Aliado, portanto, ao deslocamento de signos, o trabalho com a hipertextualidade incide sobre o enunciatário e demanda maior engajamento do que o demandado por narrativas tradicionais. Verdadeiro co-enunciador da obra, seu repertório prévio é essencial ao funcionamento do pastiche, da hipérbole e das alegorias postas em ação.

\section{- Lição antropofágica}

Desvelando a construção dos mitos na contemporaneidade, PanAmérica atualiza a prosa nacional a partir de farto material egresso da cultura pop, em total consonância com prática pop e Tropicalista, cuja antropofagia remete às experimentações modernistas. A "devoração" é radical: os ícones da sociedade de consumo são inseridos na narrativa, incidindo sobre a consciência significante do leitor, por meio do deslocamento contínuo dos signos. Aliás, o próprio índice antropofágico é figurativizado ao longo do romance, salta à vista a quantidade de vezes em que o narrador se alimenta. Trata-se de um férrico e indigesto festival gastronômico composto de doces, biscoitos, pão, sanduíches, frango assado, Coca-Cola, cremes, balas, carnes mastigadas aqui e ali, conforme transita por restaurantes, bares e em torno de bandejas que surgem, do nada, cheias de alimento. Ele também anuncia suas idas ao banheiro, chegando 
inclusive a defecar em uma latrina; toma banho repetidas vezes, descreve suas sensações debaixo d'água; e, sobretudo, faz sexo.

A afirmação do corpo e da sexualidade, em sintonia com a sublevação dos corpos apontada por Paz (cf. p.103), desafia quaisquer restrições morais e religiosas de uma sociedade seduzida naquele momento pelas marchas "da Família com Deus pela Liberdade". Inundada de erotismo, a narrativa apresenta o fazer sexual enquanto aventura sensorial sem quaisquer restrições: mulheres, homens e crianças, o corpo consome as identidades enquanto espaço de combustão contínua da libido; e o enunciatário é conduzido, pela experimentação sensorial, à fruição de desejos contidos e inacessíveis, exposto tanto a temas tabus do período, quanto a temas interditos nos noticiários da época. Trata-se, portanto, de um posicionamento radicalmente acrático em relação à doxa. Em última instância, PanAmérica tematiza a liberdade, operando radical dessacralização dos poderes que constituem o mundo e a própria narrativa, implodida no final da obra.

O poder de sua crítica e de seu engajamento reside na forma como diz, sem precisar discorrer sobre é o que dito. É dessa forma que Agrippino de Paula, com sua lente hiperbólica e sensorial nos conduz para além de quaisquer dicotomias, sejam elas ideológicas, estéticas ou comportamentais, apropriandose da linguagem verbal não para encerrá-la, mas para libertá-la sob possante imaginação criadora.

Por meio da deglutição antropofágica, do diálogo intertextual, da saturação semântica, da parataxe à serviço da lente cinematográfica, PanAmérica constrói a obliquidade enquanto força propulsora do seu regime de realidade. Isso muito nos diz sobre a obra e, em particular, sobre o período de sua escritura: um momento em que o discurso oficial sobre a realidade negava, como sabemos, a verdade dos fatos.

Grosso modo, podemos observar neste processo, o delírio enquanto efeito de sentido, decorrentes da correlação entre os planos de expressão e conteúdo, seja ele:

(1) O delírio figurativo. Os atores (todos egressos do mass media) se apresentam como avatares, encenando os mais variados percursos e gêneros 
de filmes. Nem mesmo o sujeito, narrador da obra, escapa do processo de saturação semântica, construída por um contínuo agir, sem qualquer dimensão analítica ou psicológica.

(2) O delírio paratático. Resultante da afirmação da descontinuidade narrativa desde as unidades mais básicas, como a justaposição de orações que obedecem a estrutura $\mathrm{S}+\mathrm{V}+\mathrm{O}$ até a justaposição de unidades cênicas que mantém determinada independência temática. $O$ resultado é uma narrativa constituída aos moldes do cinema de montagem.

(3) O delírio cinematográfico. Resultante do delírio paratático, e acrescido na tematização do universo cinematográfico e pop, com emprego de cortes de planos, aproximações e distanciamentos que emulam a câmera cinematográfica.

(4) O delírio intertextual. A narrativa vai se constituindo como uma somatória, sem hierarquias, dos mais variados discursos, culminando na implosão final, em espécie de saturação do processo de adição infinita desses discursos.

(5) O delírio performático. Dado o jogo intertextual, o enunciatário de PanAmérica é levado a uma constante necessidade de preencher as lacunas abertas pela referencialidade, em um contínuo desvendamento da narrativa. $\mathrm{Na}$ medida em que há sempre uma cena por trás de outra cena, reiterando a cultura do simulacro em que vivemos, e demandando desse enunciatário uma performance mais ativa que passiva. 


\subsection{O regime referencial em Zero}

Algumas obras marcam época, adquirem história própria, ecoam gritos e anseios coletivos. Zero, de Ignácio de Loyola Brandão, é uma delas. Planejada, escrita e publicada em pleno terror de Estado, durante a ditadura militar (196485), o texto amargou dois anos de censura, por desacato à moral e aos bons costumes. Em edição comemorativa dos 25 anos (Global, 2010) da obra, Loyola detalha a história do romance, publicado primeiramente na Itália, em 1974, pela editora de Giangiacomo Feltrinelli, "um milionário e comunista que tinha revelado ao mundo Dr. Jivago" de Boris Pasternak, proibido de circular na União Soviética de Joseph Stalin, conta (Brandão, 2010, p.18).

A ideia de lançar Zero primeiramente na Itália correspondeu à dificuldade de encontrar editoras dispostas a assumir os riscos da publicação de um texto com tamanha inventividade formal e, sobretudo, com temática subversiva aos padrões da ditadura. Além disso, Loyola acreditava que a publicação internacional lhe dava certa proteção - "se me tocassem, haveria repercussão" (ibidem) -, e ainda poderia ajudar na divulgação, no exterior, das violações sistemáticas contra os direitos humanos em curso no Brasil.

A cada dia sentia que aquele livro era o atoleiro em que o país se metera. Os subterrâneos, os esgotos, os gritos dos feridos e dos torturados, as mortes, os suicídios, as dores, os amores impossíveis, os casais desfeitos, a liberdade encurralada, o medo sempre presente, os cassados, os cientistas que partiam (ibidem, p.16).

O romance foi lançado no país somente em outubro de 1975, meses após o assassinato de Wladimir Herzog, diretor de jornalismo da TV Cultura, nas dependências do DOI-Codi em São Paulo, levando uma multidão em ato ecumênico na Praça da Sé, em uma das primeiras reações populares de vulto após a promulgação do Al-5. Publicado por Ligia Jobim, que mantinha a editora Brasília-Rio, Zero foi sucesso imediato, tanto de crítica quanto de público, surpreendendo Loyola que, ciente das experimentações do romance, inspirado 
em Oito e Meio de Fellini, questionava-se se aquele texto "era um livro?" e, caso fosse, "quem leria um livro desses?" (ibidem).

Em uma semana, Zero entrava na lista dos mais vendidos, e foi justamente esse o problema. Com o sucesso, em pouco tempo, o romance começou a circular pelas "mesas de biriba das mulheres dos coronéis em Brasília" que trocavam "dicas sobre filmes imorais, livros, peças, canções" referenciados na obra. Meses depois, Loyola era alertado sobre a censura iminente por um polonês "muito culto" e censor na Editora Três, onde trabalhava: "se [a censura] for por motivação política, complica bem, você poderá sofrer um processo, ser preso, condenado. Se a causa for moral, esqueça, deixa correr, será apenas um livro proibido". No dia seguinte, conta Loyola, o censor lhe telefonava: "boas notícias para você. O livro foi proibido com base na moral e nos bons costumes. Parabéns" (ibidem, p.18-19).

Era o ano de 1976 e além de Zero, Armando Falcão, então ministro da Justiça, já havia censurado o livro-reportagem de José Louzeiro, Araceli, meu amor, a pedido do advogado de defesa dos suspeitos pelo estupro e assassinato (o caso nunca foi desvendado) da menina de oito anos, no Espírito Santo. E, também, o clássico de Rubem Fonseca, Feliz Ano Novo que, segundo Loyola, não saia da gaveta do ministro. "Quando os três livros foram vetados, iniciou-se, em Minas Gerais, um movimento que, em algumas semanas, tomou o Brasil de ponta a ponta" (ibidem, p.33), resultando em manifesto assinado por 1.046 intelectuais e artistas. Em 25 de janeiro de 1977, comitiva formada por Lygia Fagundes Telles, Nélida Piñon, Jeferson Ribeiro de Andrade e Hélio Silva desembarcava em Brasília para entregar o documento ao ministro da Justiça que, desrespeitoso, recusou-se a receber os escritores.

No dia seguinte, os jornais não apenas cobriram a negativa do ministro, como estamparam em páginas inteiras o manifesto que afirmava:

(...) Cabe a todos nós, especialmente neste momento ao Senhor Ministro, decidir se há uma história, uma cultura e uma língua brasileira a merecerem resgate, preservação, manutenção permanentes. Se afinal somos ou não viáveis como povo pensante, ou se acaso devemos abafar para sempre o potencial criativo desta Nação. Não nos esqueçamos de que a arte, com 
seus desafios, sua invenção, suas antecipações, recolhe o pulsar de um povo, revela-lhe o rosto e o sentimento, indica que caminhos ele está a tomar (ibidem, p. 33).

Somente em 1979, Zero voltou a circular no país. Foi, aliás, um dos primeiros livros liberados pela censura, de uma lista com quase quinhentos títulos. Eram "tempos de abertura" e João Figueiredo - autor de frases como "prefiro cheiro de cavalos ao cheiro do povo" e "quem for contra a abertura, eu prendo e arrebento" - ascendia ao poder com a missão de tornar a transição da ditadura à democracia a mais favorável possível para os militares e, em particular, aos civis que não só apoiaram, como financiaram e se esbaldaram com a repressão de lideranças políticas, sindicais e populares ao longo de 21 anos. Relançada, portanto, naquele promissor ano de 1979, pela Editora Pasquim, Zero vendeu cinco mil exemplares em apenas uma semana. Ao refletir sobre o episódio, Loyola é categórico:

A proibição de um livro é uma violência. Contra a obra, contra o criador, contra a sociedade. O que me espanta na censura é que ela seja aceita passivamente. Não entendo como cada cidadão pode suportar uma organização que determina o que ele pode ou não pode ler, assistir, ouvir. Cerceando, limitando, proibindo, a censura trata a cada um de nós como crianças, como imaturos, como débeis mentais, sem capacidade de escolha, de livrearbítrio. (ibidem, p. 51).

É dessa indignação, acima manifesta, que Zero surgiu. Num primeiro momento, enquanto ação cidadã de um jornalista que, frente à violência da censura nas redações onde trabalhava, passou a recolher sistematicamente qualquer material proibido que caia em suas mãos.

Eu amontoei no apartamento todas as matérias censuradas. As velhas e as novas, que a cada dia tinha mais, e mais, e mais. $\mathrm{E}$ a cada dia pegava um papel e escrevia alguma coisa em cima. Uma ficção-realidade. (ibidem, p. 16, grifos nossos). 
Num segundo momento, o jornalista e o escritor se encontraram, e Loyola começou a refletir sobre o que fazer com material tão diverso e vasto. Foram nove anos de trabalho que resultaram em quatro mil laudas escritas até o romance chegar no atual formato. Loyola inclusive relata que José Celso Martinez Corrêa, diretor do Teatro Oficina, foi um dos que sugeriram o romance como melhor gênero para abranger a heterogeneidade daquele farto material. Em grande parte, conteúdo censurado, portanto, o romance traz uma fração do real que ninguém, além dos envolvidos, dos jornalistas e dos censores, soube que ocorrera. Daí o experimentalismo da obra: para abarcar tantos e tão variados discursos, a narrativa se tornou inteiramente fragmentada, como um grande mosaico, com temas e gêneros diversos.

Uma autêntica "ficção-realidade", incorporando as palavras do autor, que articula fragmentos de discursos do real (trechos de jornal, excerto de romances, declarações oficiais), por meio de uma série de relações transtextuais. Lançado sete anos depois de PanAmérica, em contexto não mais de transformações no ambiente nacional, mas sim de brutal repressão contra "os inimigos do Brasil", com Exército nas ruas e resistência clandestina, Zero afirmará, e de modo contundente, os índices de referencialidade que remetem às várias violências daquele momento, em particular: a carestia e a luta desigual pela sobrevivência, a violação aos direitos civis e humanos, a falácia dos valores do senso comum (família, matrimônio, casa própria), a violência do Estado (mandonismo, autoritarismo) e outros temas construídos a partir da perspectiva da classe trabalhadora tratada como "zero à esquerda" no jogo das relações de poder, permanentemente autoritárias e hierárquicas da sociedade brasileira.

Essa crítica se torna ainda mais potente a partir do caráter verbivocovisual da obra que abrange as linguagens oral, verbal e visual, afinal não se trata apenas de vocalizar o grito, mas de amplificar sua escuta, por todas as linguagens possíveis naquele momento de silenciamento, violações (sequestros e assassinatos cometidos pelo Estado) e asfixia da inteligência nacional.

O que pretendemos observar, a partir de agora, é como esse regime referencial é sustentado na narrativa e, sobretudo, como sua apreensão é 
potencializada a partir de procedimentos experimentais que incidem, essencialmente, sobre temas e figuras da contemporaneidade da obra.

Como aponta Bertrand,

A literatura é, entre outros, um discurso figurativo: ele representa, estabelece, na leitura, uma relação imediata, uma semelhança, uma correspondência entre as figuras semânticas que desfilam sob os olhos do leitor e as do mundo, que ele experimenta sem cessar em sua experiência sensível. É a mimesis. Essa dimensão se interessa pela maneira como se inscreve o sensível na linguagem e no discurso, ou seja, basicamente, a percepção e as formas de sensorialidade. Essa dimensão figurativa da significação, a mais superficial e rica, a do imediato acesso ao sentido, é tecida no texto por isotopias semânticas, e recobre com toda sua variedade cintilante de imagens as outras dimensões, mais abstratas de profundas. Ela dá ao leitor, assim como ao espectador de um quadro ou de um filme, o mundo a ver, a sentir, a experimentar. (Bertrand, 2003, p.29).

Em Zero, essas isotopias semânticas são organizadas em dois eixos: as isotopias que nos remetem à conjuntura da obra, ou seja, o conteúdo referencial trabalhado e inserido sob outros gêneros discursivos, o jornalístico, o diário íntimo, a crônica, o poema, o ditado popular etc. Em paralelo a esse eixo conjuntural, temos o eixo ficcional que traz o programa narrativo em torno de José, que também irá afirmar a referencialidade ao tematizar a vida de um trabalhador brasileiro, no caso, um sujeito de 28 anos, sem perspectiva alguma, que luta para sobreviver - e ser feliz - em uma megalópole como São Paulo, periferia do capitalismo. É do imbricamento desses dois eixos, o conjuntural que nos traz o país e a saga de José, que teremos a construção da ilusão de referencialidade na obra. 


\subsubsection{A "ficção-realidade"}

No início deste terceiro capítulo, pudemos observar como o discurso referencial da publicidade persuade o enunciatário a partir de elementos como verossimilhança, testemunho, comparação de fatos. As mesmas estratégias são potencializadas pela experimentação em Zero, que essencialmente consiste no imbricamento desses dois percursos narrativos: o conjuntural composto pelo material coletado pelo autor, retrabalhado de modo ficcional no romance, mas mantendo suas coerções de gênero; e o percurso essencialmente ficcional, relativo à saga do sujeito José.

Essa camada de referencialidade atua, em caráter persuasivo, no contrato de veridicção entre enunciador e enunciatário; apresenta-se enquanto prova da história que narra, garantindo coesão à fragmentação narrativa. Além desse material "comprobatório", Zero é contado a partir de uma pluralidade de perspectivas trabalhadas na enunciação, resultantes da combinação de gêneros, linguagens e modos de enunciação variados, constituindo-se prosa híbrida, como podemos observar na montagem da próxima página: 
Figura 13 - Visão panorâmica de Zero

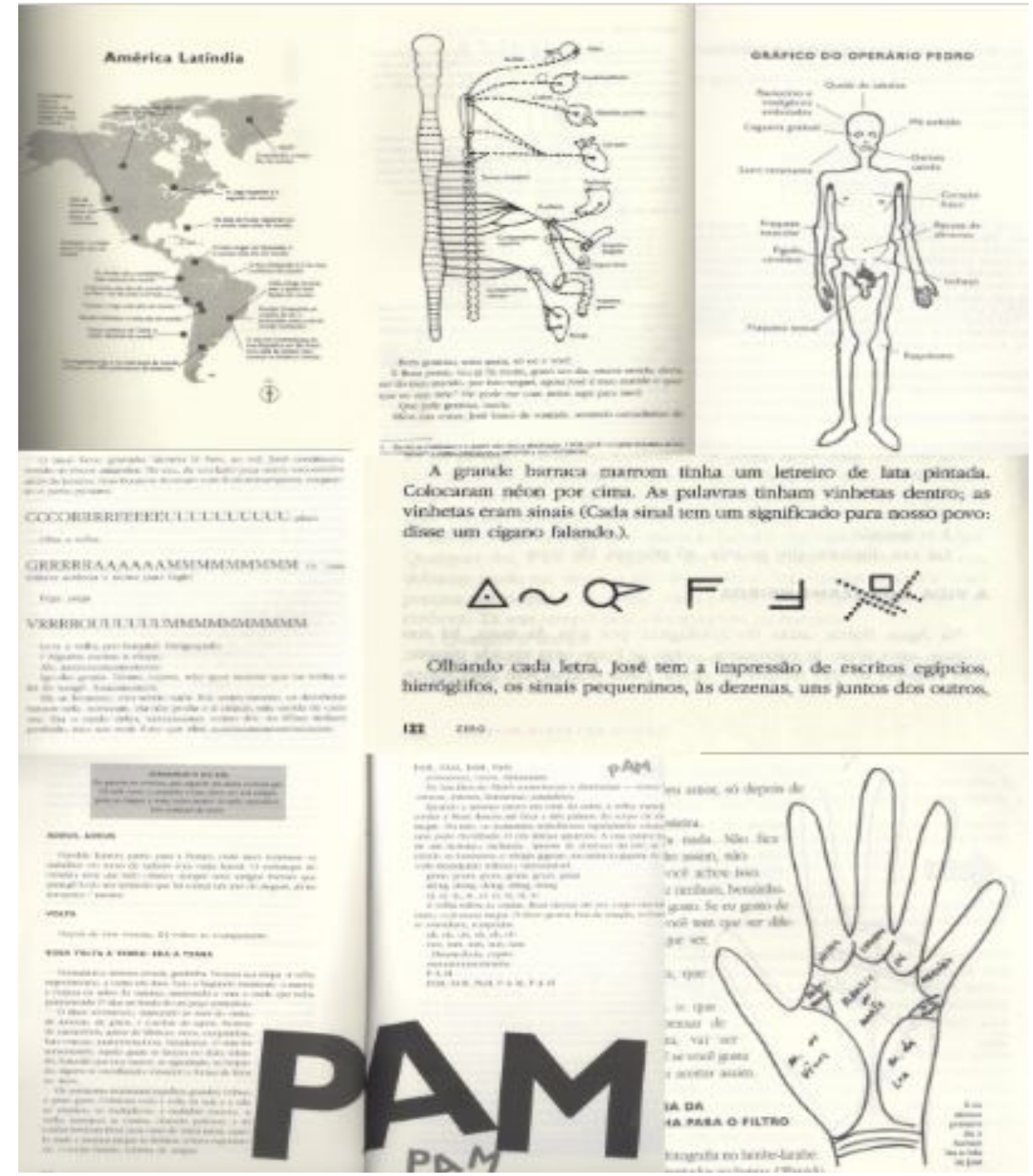

(Zero, 201032)

Acima podemos identificar três estímulos principais: sonoro (onomatopeias); visual (imagens) e verbal (textos), possibilitados pelo imbricamento de duas semióticas principais, a verbal e a visual, em amplo espectro de experimentações. Construída, portanto, como grande mosaico verbivocovisual (de estímulos sonoros, verbais e visuais), Zero é a composição de unidades semânticas, apresentadas como microcapítulos com extensão, gênero e discursos independentes. É possível, por exemplo, encontrar excerto de romance, cardápio, parte da trama, tampa de Coca-Cola, dispostos lado a

32 Montagem a partir de várias páginas da obra. A partir de agora, as citações da obra serão antecedidas por Zero, seguido do número da página. 
lado; em microcapítulos de um ou dois parágrafos a capítulos de duas a três laudas. A regra é a heterogeneidade, pela qual cada fragmento se apresenta enquanto unidade de sentido, ou várias unidades como séries temáticas, refletindo em sua fragmentação o modo disperso da coleta desse material, durante a passagem de Loyola pelas redações de "Última Hora", "Cláudia", "Realidade", "Planeta", entre outros.

Podemos conceber sua estrutura experimental como meio de tornar coesa a diversidade desse material recolhido em narrativa muito mais descontínua formalmente do que PanAmérica, cujas unidades cênicas apresentam relativa interdependência. Em Zero, as unidades nem sempre dialogam, sequer são enunciadas por um mesmo narrador. Os procedimentos experimentais atuam, neste sentido, como ordenadores da heterogeneidade, imbricando esse conteúdo em dois percursos bem demarcados em torno de isotopias figurativas e temáticas.

Como explica Diana Barros (Linguística - USP), em Teoria do Discurso: fundamentos semióticos (1988), "a isotopia temática surge da recorrência de unidades semânticas abstratas em um mesmo percurso temático"; e é por isso que podemos dizer que determinado livro trata de questões de liberdade, que um quadro pinta a velhice, "só podemos fazer essas generalizações pelo reconhecimento da isotopia temática" (Barros, 2002: 125). Já a isotopia figurativa, irá

\begin{abstract}
caracterizar os discursos que se deixam recobrir totalmente por um ou mais percursos figurativos. A redundância de traços figurativos, a associação de figuras aparentadas atribui ao discurso uma imagem organizada e completa de realidade ou cria a ilusão total do irreal, a que já se fizeram muitas referências. Assegura-se, assim, a coerência figurativa do discurso. A coerência semântica do discurso dá-se, portanto, em função de suas isotopias temáticas e figurativas ou de uma isotopia temática, ao menos. (Barros, 2002, p.125)
\end{abstract}

Em Zero, podemos identificar quatro isotopias temáticas em torno das quais giram os mais diversos fragmentos (microcapítulos) desse segundo plano narrativo do romance: (1) a luta pela sobrevivência; (2) a opressão do Estado militar; (3) as relações eróticas e afetivas; e (4) a busca pelo sentido da vida. Essas isotopias temáticas, por sua vez, orientam-se sob a perspectiva do 
trabalhador brasileiro, a massa urbana explorada, ou seja, a pelo viés da imensa maioria que sequer sentiu o aroma "do bolo" prometido pelo então ministro Delfim Netto, autor da expressão "primeiro temos de fazer o bolo crescer para depois distribuí-lo", vulgo primeiro os ricos, depois os pobres.

As variadas isotopias figurativas que irão revestir essas isotopias temáticas gravitam e se organizam em torno da oposição semântica liberdade vs. opressão do nível fundamental do percurso gerativo de sentido, sendo a liberdade um valor eufórico, e a opressão, disfórico. Inclusive, a resistência contra a opressão está presente tanto no plano de conteúdo quanto o de expressão da obra, na medida em que as marcas performáticas de sua elaboração, em particular, a coleta do material censurado dialogam com seu conteúdo, ou mais especificamente, com a estruturação de seu conteúdo, desde a tematização à fragmentação da narrativa.

Como sabemos, a realidade em uma obra de arte é constituída enquanto efeito de sentido, ou nas palavras do linguista José Luiz Fiorin (Linguística -USP), "os actantes, os tempos e os espaços linguísticos stricto sensu não refletem as pessoas reais, nem o tempo físico, nem o espaço geométrico, mas são criados na e pela enunciação" (Fiorin, 2016, p. 270). Vejamos, portanto, como essa realidade é construída em Zero, a partir do entrelaçamento do programa narrativo centrado na história de José Gonçalves; e de outros programas narrativos de sujeitos variados, composto por discursos censurados pela ditadura ou referenciados pela obra.

\section{- Considerações preliminares}

Em PanAmérica, nós pudemos observar a construção da obliquidade, a partir da incidência de procedimentos experimentais no plano de expressão e nos processos de figurativização e tematização (semântica discursiva), com menor incidência nos processos de enunciação (sintaxe discursiva) da obra, onde ocorrem os processos de actorizalização, temporalização e espacialização. O que iremos acompanhar em Zero é o contrário, a experimentação incidirá 
muito mais sobre os modos da enunciação do que sobre os processos de figurativização. Nosso foco será, portanto, na sintaxe discursiva do plano de conteúdo, onde a heterogeneidade enunciativa irá decorrer do imbricamento de distintos gêneros textuais (a partir da transtextualidade) e da combinação de diferentes linguagens (sincretismo verbivocovisual).

Em As Astúcias da Enunciação (2016), Fiorin traz ferramentas de grande valia à compreensão da diversidade enunciativa em Zero. "Mecanismo de criação da pessoa, do espaço e do tempo da enunciação e, ao mesmo tempo, da representação actancial, espacial e temporal do enunciado" (Fiorin, 2016, p.37), a discursivização é crucial à compreensão dos regimes de construção da realidade, afinal, é quando "as estruturas semióticas virtuais se realizam sob a forma do discurso". Ele localiza em cada discurso três dimensões enunciativas:

(1) A enunciação enunciada que remete à instância da enunciação propriamente dita, com marcas bem definidas. Como exemplo de enunciação enunciada, Fiorin cita o quadro de Claude Monet (Figura 14), A catedral de Ruão (1894), no qual "todos os traços são apreciações que remetem à instância enunciativa" e o que se busca ao observar não é a catedral ou o real, "mas a cambiante impressão que ele causa aos olhos e à alma do artista" (ibidem, p.46). Temos, portanto, a presença bem marcada da enunciação;

(2) A enunciação reportada que remete à metalinguagem, como vemos em A condição humana (1933) de Magritte (Figura 15), que denuncia o fazer artístico ao expor na tela as pernas do cavalete, inserindo-se enquanto "simulacro do ato enunciativo e de suas ilusões: a pintura mostra que o pintor pintou $x, y, z$ " (ibidem, p. 47);

(3) O enunciado enunciado que cria a ilusão de extrema objetividade, apagando as marcas de enunciação. Fiorin cita como exemplo $A$ baía de São Marcos com o retorno do Bucentauro (1727 a 1729) de Canaletto (Figura 16) "em que parece estar afastada a enunciação enunciada. É como se pudéssemos ver "a vista real" do canal, por meio de uma "transcrição literal e impessoal" (ibidem, p. 46). 
Figura 14 - Enunciação enunciada

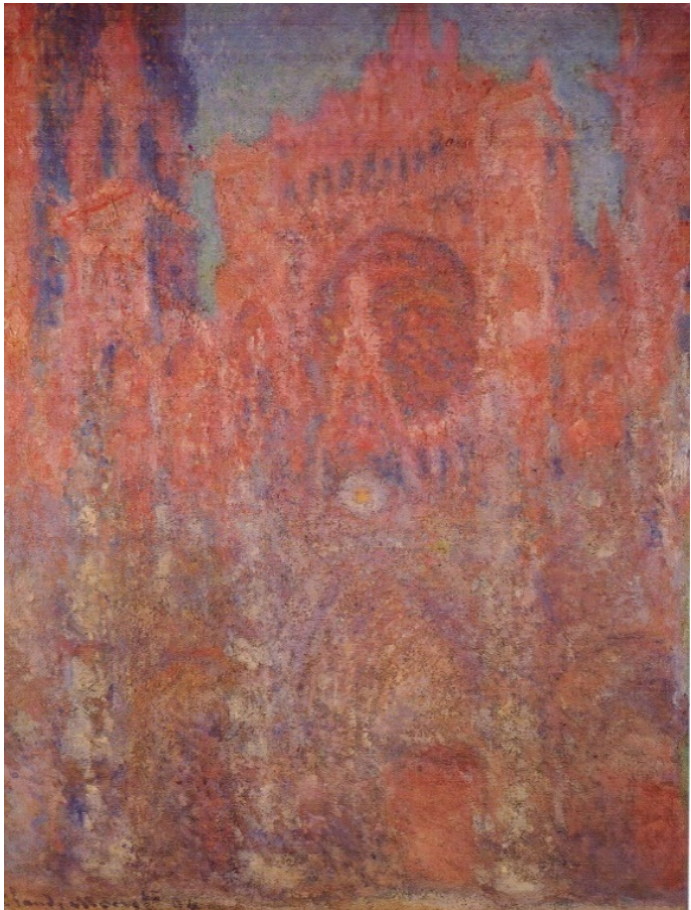

Figura 14: $A$ catedral de Figura 15: A condição humana, de Magritte
Figura 15 - Enunciação reportada

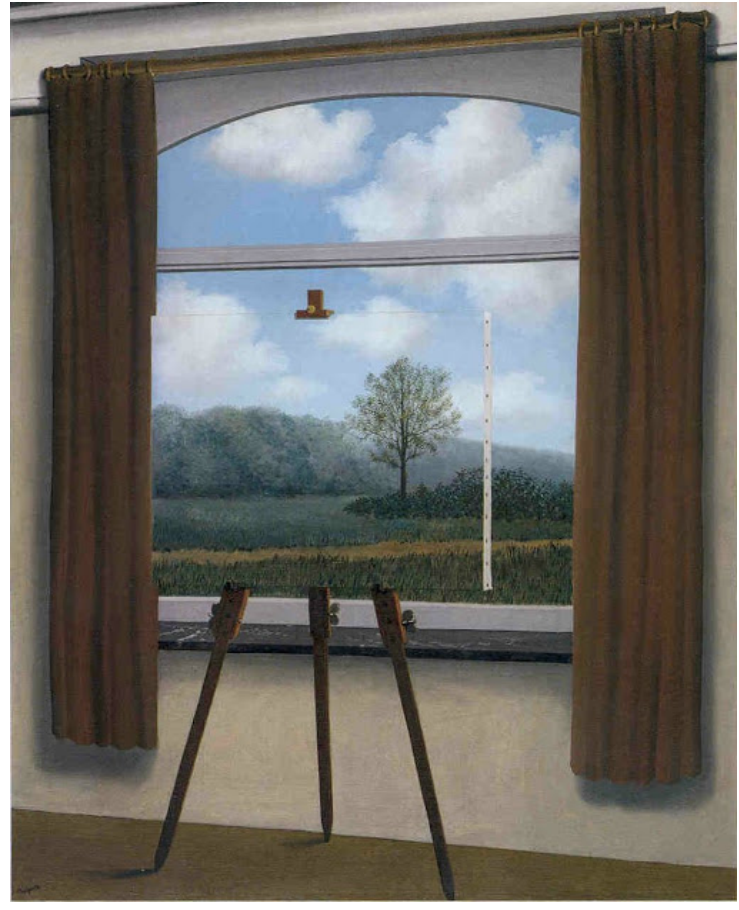

Ruão, de Claude

Monet

Figura 16 - Enunciado enunciado

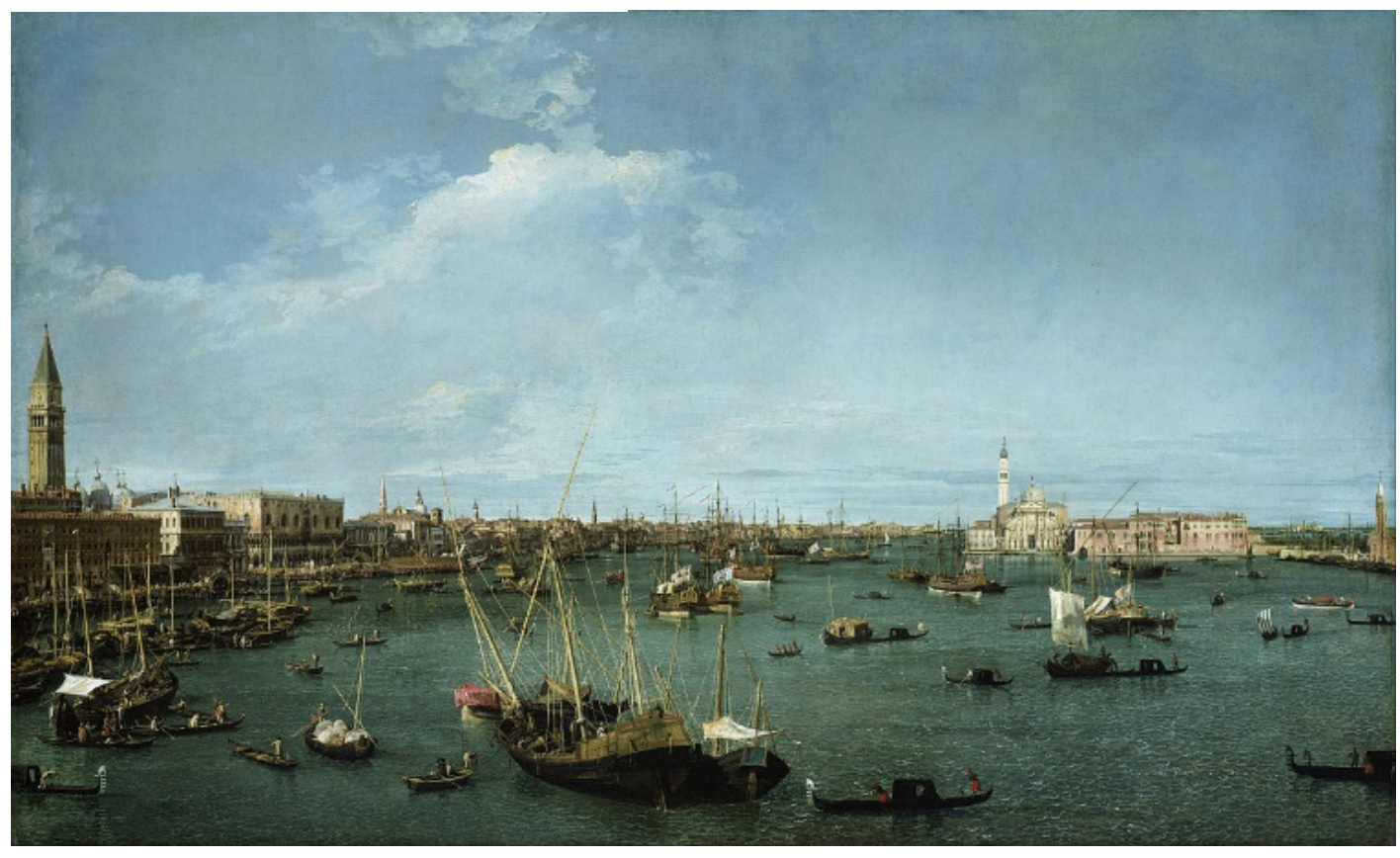

A baía de São Marcos com o retorno do Bucentauro, de Canaletto

Em Zero, essas três dimensões irão se alternar o tempo todo a partir de distintas focalizações. 


\section{- Foco narrativo}

Como explica Fiorin, a semiótica, em sua análise sobre o foco narrativo, procurou fugir da dicotomia narrador em primeira ou em terceira pessoa, propondo duas instâncias: a do narrador e a do observador. Segundo essa concepção, narrador é o "destinador do discurso explicitamente instalado no enunciado", o actante da enunciação enunciada que pode estar "em sincretismo com um dos actantes do enunciado" (Greimas e Courtés, 1979, p.242), por exemplo, quando surge em primeira pessoa identificado com o sujeito da ação narrativa. O observador, por sua vez, é o sujeito cognitivo, por excelência,

delegado pelo enunciador e instalado por ele no enunciado, onde é encarregado de um fazer receptivo e, eventualmente, de um fazer interpretativo, que incidem sobre os actantes da narrativa e os programas narrativos que participam. (ibidem, $p$. 92)

O conhecimento desse narrador, por sua vez, pode ser apreendido por meio de uma focalização parcial ou total. Quando parcial, a focalização pode ser interna ou externa. No primeiro caso, o observador é um dos actantes da narrativa (sujeito ou não) e relata a cena sempre a partir de seu ponto de vista, e tudo o que sabemos depende do seu alcance; no segundo, de focalização externa, o observador está completamente fora da cena, e jamais saberemos seu íntimo, "vemos apenas as ações das personagens, não sabemos quais são seus pensamentos e sentimentos" (ibidem, p.96).

Já no processo de focalização total, o narrador assume o papel de observador onisciente, ou seja, aquele que "sabe mais que as personagens, conhece os sentimentos e os pensamentos de cada uma delas" (ibidem, p.98), antecipa o fim da história, comenta e interfere na nossa interpretação dos fatos. Grosso modo, cabe ao narrador "falar" e ao observador "encarregar-se da dimensão cognitiva da narrativa" (ibidem, p. 94). Ambos, porém, estão atados na medida em que "o narrador só pode relatar o que o observador sabe", e essas duas formas se alternam. 
O narrador também pode se projetar de modo distinto na enunciação e no enunciado. Quando ocorre um processo de debreagem enunciativa da enunciação, os actantes se projetam no enunciado, por exemplo, por meio de um narrador intruso em terceira pessoa que diz "eu", ou simplesmente por um narrador em primeira pessoa; quando ocorre uma debreagem enunciva da enunciação, esses actantes simplesmente desaparecem, e não se projetam no enunciado. O mesmo processo de actorizalização pode ocorrer no enunciado por debreagem enunciativa do enunciado, quando o narrador se identifica com alguma personagem; ou por debreagem enunciva do enunciado, quando isso não ocorre, e tanto em romances de primeira ou de terceira pessoa. (ibidem, p. 103-104).

O que singulariza o processo de discursivização em Zero, daí a citação da teoria acima, é que todas essas possibilidades estão previstas e vão se alternar ao longo da narrativa - enunciação enunciada, enunciado enunciado, enunciação reportada, focalização parcial interna, parcial externa e total do observador, actorialização por debreagem enunciva e enunciativa seja da enunciação, seja do enunciado. Isso decorre, grande parte, das relações de transtextualidade que compõem a narrativa, conduzindo à justaposição de diferentes gêneros textuais, cada qual com seu modo de enunciação, focalização e debreagem, compondo esse grande mosaico formado por "textos de segunda mão" ou hipertextos, regidos pelas coerções do texto de origem.

Essa pluralidade de perspectivas se organiza em torno de isotopias temáticas e figurativas que nos colocam diante do cotidiano, visão de mundo e horizonte de expectativas de atores que representam a população mais pobre, que carece de moradia, de bons empregos, em suma: a imensa maioria dos trabalhadores brasileiros. Eles irão aparecer em dois percursos narrativos que se imbricam: (1) um multifacetado, composto por variados sujeitos e marcado pelas relações transtextuais; e (2) outro, em torno da saga de José, um jovem de 28 anos que passa do subemprego à contravenção, e da contravenção à luta armada.

Ambos os percursos se complementam, mas o primeiro conjuntural pode ser concebido de modo independente ao percurso do sujeito, embora crucial à 
ambientação e compreensão do universo desse personagem e percurso ficcional, exclusivamente em torno do sujeito José, embora saibamos que ambos são construções ficcionais. De modo geral, o percurso contextual fortalece o contrato veridictório entre enunciador e enunciatário proposto pelo percurso ficcional, como veremos adiante.

\subsubsection{A saga de José, o percurso ficcional}

Zero nos conduz ao Brasil dos anos 1970, em meio a multiplicidade de discursos em torno e sob a perspectiva de José Gonçalves, jovem de 28 anos que mora sozinho em uma pensão no Centro da capital paulista, sobrevivendo de subemprego em subemprego. Em permanente dificuldade financeira, José expressa as angústias e dificuldades de um cidadão da periferia do capitalismo mundial, que trabalha constantemente na informalidade, e experimenta 0 acirramento da carestia de uma população essencialmente urbana - tudo se passa em São Paulo --, e alijada das benesses do "milagre brasileiro", quando o país atingia um PIB de $14 \%$ em 1973, sem que isso se revertesse em oportunidades a trabalhadores como José.

Apesar da penúria material, ele é um jovem dos anos 1960, que largou a faculdade de Direito, que gosta de livros, de música, de cinema, consome cultura popular e underground, e que perambula pela "boca do lixo" e pelos "inferninhos" da megalópole paulistana. Ele busca diversão, sexo, amor, um trabalho melhor, e pensa sobre o país, o passado, o sentido da vida e, em particular, sobre as preocupações que o rodeiam, sobretudo, após seu casamento com Rosa, que o persuade a comprar a casa própria, afundando-o em dívidas. Ao lado de Átila, seu único amigo, ele passará progressivamente do trabalho informal à contravenção. E, posteriormente, também por meio de Átila, destinador de suas ações, começará a prestar serviços para os Comuns, tornando-se amigo do líder revolucionário "Gê", em alusão nada sutil aos comunistas e ao próprio Che Guevara, apresentado em tom essencialmente messiânico. 
O destino desse sujeito, bem como o dos principais atores da obra (e do próprio país) será trágico: José acabará numa prisão norte-americana, em mais uma presença dos Estados Unidos na construção figurativa do antissujeito no presente corpus.

Como citamos anteriormente, em meio a trama, outros percursos e séries temáticas são iniciadas, sob a forma de narrativas paralelas e independentes, que se passam no mesmo tempo e cenário, ou seja, no mesmo aqui e agora das ações do sujeito e principais atores da obra, como Rosa e Átila. Em todas essas instâncias, a construção disfórica da opressão seja a econômica (miséria) ou a militar (violência de Estado e das instituições) é constante, bem como a construção da penúria e ausência de assistência em que vivem praticamente todos os personagens. Com esse breve percurso em mãos, vejamos as experimentações que incidem sobre os níveis discursivo e narrativo e, também, sobre as modalizações passionais no plano de conteúdo, a começar pela heterogeneidade enunciativa da obra.

\section{- Heterogeneidade}

Em Zero, vários microcapítulos ou capítulos de maior fôlego problematizam o universo laboral sob a perspectiva do trabalhador, em particular, os que vivem em permanente carestia, expressando não apenas o abismo social da realidade brasileira, como a violência que permeia as relações de exploração do sistema capitalista, como podemos ver nos dois excertos abaixo "CADA RATO TEM SEU PREÇO" e "SETE ITENS".

\section{CADA RATO TEM SEU PREÇO}

Nove horas, José veste o macacão, calça as botas de borracha e instala a aparelhagem de tambores e tubos plásticos. Aciona a manivela e produz uma fumaça amarela que vai para as tocas. Os ratos correm e logo caem. Mortos. Ele os recolhe num saco e vai jogar nos terrenos baldios da Várzea do Glicério. 
José tem uma cota diária de ratos. Ele sabe que, no dia em que tiver exterminado todos os bichos, perde o emprego. Um dia, não tinha mais ratos, José foi à Várzea, pagou 50 centavos a dois moleques, cada um trouxe três ratos. Assim, José continuou trabalhando. (Zero, p. 107).

Enunciado em debreagem enunciva que instaura as categorias de pessoa (José), tempo (nove horas) e espaço (cinema) distintas do "eu, aqui e agora", o excerto acima informa a condição social de José. Desde o primeiro momento, a sobrevivência se instaura como principal objeto de valor para esse sujeito que detém as competências para garanti-la. Como vemos acima, José é capaz de "fazer limpeza" (macacão, calça, botas de borracha, tambores, tubos, fumaça amarela) e, ao mesmo tempo, de "fazer sujeira" (tocas, ratos, mortos, saco, terrenos baldios).

Duas ações que se anulam, e que constituem a performance laboral desse rapaz manipulado por dupla intimidação, afinal, ele é tão obrigado a cumprir as ordens do destinador gerente, que o faz limpar por dinheiro; quanto ceder às pressões do destinador "medo do desemprego", que o faz sujar o cinema para se manter ativo, escancarando a ilogicidade do subemprego, afinal, quanto mais produtivo for, mais rápido José será descartado. O esvaziamento de sentido da atividade produtiva de José é contado em terceira pessoa por um observador com focalização total sobre o sujeito.

Em geral, essa perspectiva prevalece no percurso ficcional da obra, mas se alterna com a debreagem enunciativa, que instaura o narrador em primeira pessoa, como podemos observar abaixo, quando, em um mesmo microcapítulo, temos a passagem da debreagem enunciva (ele, ontem/amanhã, acolá) à enunciativa (eu, hoje, aqui), sem qualquer prejuízo à coerência argumentativa: 


\section{SETE ITENS}

1 - José não foi ver se o seu emprego de mata-ratos no cinema ainda está de pé. Não tem vontade de nada.

2 - Ele acha que não dá pé. Não vale a pena. Tem um pouco de dinheiro para ir vivendo. Amanhã ou depois, talvez ele vá ao cinema.

3 - Se for o caso, pede desculpas ao gerente diz que estava doente.

4 - Pode descontar (chefes adoram descontar) meus dias. Não falto mais, juro que não, pelo amor de Deus.

5 - É só rastejar um pouco. Eles acham que é rastejar. Mas não é. É mentir em cima deles. Ficam babados quando alguém rasteja.

6 - O bom é ficar na cama, pensando. Eu não quero é ter a mínima preocupação por nada em minha vida.

7 - Hoje de manhã veio a polícia e prendeu o sujeito do quarto da frente. Não era criminoso, nem nada. Estudante. Negócio de política. Estragaram o quarto dele inteirinho, rasgaram roupa, livros, farejaram armários.

(Zero, p.116)

Em termos de nível discursivo, nos itens 1,2 e 3 do capítulo acima, intitulado "Sete Itens", podemos identificar a debreagem enunciva (item 1) e, também, o progressivo aumento das marcas da enunciação (item 2), denunciando a proximidade entre narrador e sujeito, por meio de expressões como "não dá pé"/ "está de pé", e pelos índices anafóricos que constroem a incerteza ("amanhã ou depois", "talvez", "se for o caso") sobre o seu ir (dever) ou não (querer) trabalhar. Neste excerto, a focalização do observador sobre o sujeito é total, inclusive, sobre seus pensamentos (item 3 ).

A partir do item 4, porém, temos um processo de debreagem interna, quando o sujeito assume o papel de interlocutor, instaurando um interlocutório imaginário, no caso, o gerente. Como explica Fiorin, o efeito de sentido desse processo é o de realidade, porque a personagem parece "tomar a palavra", e o que ouvimos soa como "exatamente o que ela diz" (p.40).

Do item 5 em diante, dá-se o sincretismo entre os actantes da enunciação (narrador) e do enunciado (sujeito); e temos um processo de debreagem 
enunciativa (item 6), com focalização parcial e uso da primeira pessoa do singular ("eu não quero...") assumindo a enunciação. A partir de agora, como denota o item 7, tudo o que soubermos dependerá do saber do sujeito, restringindo nosso campo de informação ao conhecimento sobre o episódio da invasão do quarto do estudante que detém o sujeito.

Temos, assim, a passagem da debreagem enunciva (ele, lá, acolá) para a debreagem enunciativa (eu, aqui, agora), com sincretismo entre os actantes narrador e sujeito; e passagem da focalização total para a parcial. Uma verdadeira reviravolta em termos de enunciação, realizada com maestria em apenas sete parágrafos por Loyola Brandão. E esta é apenas uma entre as peças desse grande mosaico, cada um com seu modo distinto de debrear ou embrear actantes.

Em termos narrativos, essa pluralidade de perspectivas nos permite acompanhar as várias nuances da mudança de estado desse sujeito dividido entre o desejo de ficar em casa e a necessidade de trabalhar, sendo que a permanência na cama pode lhe custar a perda do meio de sobrevivência. Intimidado, portanto, pelo dever-fazer (obrigação) e tentado pelo querer-nãofazer (independência), ele prospecta uma performance imaginária, demonstrando conhecimento (saber-fazer) sobre como manipular o gerente: humilhação e desconto de salário. E, assim, para aplacar sua angústia, ele cumpre, mesmo que potencialmente, a performance demandada pelo gerente suplicando e ganhando menos -, em troca da independência, seu principal objeto de valor, e que consiste, em termos modais, no direito de poder-não-fazer (faltar no trabalho).

Acrescentadas ao paradoxo do subemprego do microcapítulo "CADA RATO TEM SEU PREÇO", as relações de exploração do trabalho são caracterizadas pelo prazer dos que detêm o poder de mando em humilhar os que não o detêm, afinal não basta retirar direitos e manter o cidadão sob a incerteza constante do dia seguinte, é preciso humilhar, fazê-lo suplicar, porque esse é o cerne das relações de trabalho no Brasil, sobretudo, quando se trata de relações diretas entre empregado e negociador, marcadas pela tensão entre o poder-não-fazer (independência) e não-poder-não-fazer (Obediência); e o poder- 
fazer (liberdade) e o não-poder-fazer (impotência), constitutivas da luta de classes.

No caso acima, à disforia anterior (subemprego) se soma a disforia das relações laborais permeadas pela humilhação. Não espanta, que uma vez garantida a sobrevivência ("tem um pouco de dinheiro para ir vivendo"), o sujeito não encontre motivação que justifique seu fazer, porém, ele não pode se livrar do gerente, porque precisa assegurar a sobrevivência: mais uma vez, o gerente precisa ser enganado ("diz que estava doente"). Dois percursos são, a partir daí, acionados, remetendo-nos à oposição liberdade vs. opressão do plano fundamental do percurso gerativo:

(1) O da opressão, que tematiza a obediência (não-poder-não-fazer) do sujeito. Neste caso o gerente é o destinador das ações desse sujeito, manipulando seu dever-fazer pela intimidação, afinal, sem emprego ele não tem dinheiro;

(2) O da liberdade, que tematiza a independência (poder-não-fazer) do sujeito, e em busca da qual ele irá, pelo diálogo em potencial, manipular o fazer do gerente, assumindo o papel de destinador, e convencendo o gerente a aceitálo de volta.

Mas, como age esse sujeito?

Ele se torna destinador das ações do gerente de dois modos: por meio da sedução, ou seja, valorizando os atributos do destinatário (gerente), no caso a posição hierárquica do gerente, ao suplicar ("juro por Deus") e se apresentar de modo rastejante; e por meio da tentação, reduzindo o valor do serviço (pode descontar). Dois caminhos que expressam a realidade das negociações no âmbito da informalidade.

A manipulação, por sua vez, só é possível porque em momento algum o sujeito assume a posição de humilhado, e este é um dos elementos centrais na obra. José tem plena consciência de que o sucesso de sua manipulação depende de uma fraqueza do gerente - o prazer que de vê-lo rastejar - e este saber o capacita, fazendo dele destinador (e não destinatário) das ações do gerente, afinal, 
A manipulação só será bem-sucedida se o sistema de valores que está por detrás dela for compartilhado pelo manipulado. Volta-se à questão do contrato fiduciário. O bom funcionamento da manipulação pressupõe uma certa cumplicidade entre manipulador e manipulado. Assim, se o destinatário provocado não se importar de ser chamado de covarde, ele não será levado, no saloon, ao duelo (...) Escapar da manipulação, além de significar a recusa em participar do jogo, constitui, também, a proposição de outro sistema de valores. (Barros, 2002, p.39)

Ao recusar participar do jogo, o sujeito prospecta sua manipulação, introduzindo outro sistema de valores, e implodindo pela afirmação da independência, as relações de mando e obediência do universo laboral. É assim que a angústia inicial é aplacada, permitindo-o continuar na cama e até mesmo almejar "não ter mais nenhuma preocupação em sua vida" (item 6).

Como explica Diana Barros (Linguística - USP), em "Teoria do Discurso" (1988) as categorias que se projetam no nível das estruturas fundamentais se articulam em euforia vs. disforia ou tensão vs. relaxamento.

Enquanto a categoria tímico-fórica corresponde, no nível das estruturas fundamentais, às relações de tensão e de relaxamento do ser vivo com seu contexto, as categorias modais ou modalidades determinam, na instância narrativa, as relações que ligam o sujeito ao objeto-valor. Em outras palavras, as categorias modais modificam as relações do sujeito com os valores. A conversão da categoria tímico-fórica em categorias modais diferenciadas e interdefinidas resulta de novas articulações significantes responsáveis pelo enriquecimento semântico das etapas do percurso gerativo do sentido. (Ibidem, p. 47-48)

Temos, portanto, a passagem do estado de tensão inicial, relativa à manutenção da sobrevivência (itens 1 a 4) para o estado de tranquilidade da performance imaginada (itens 5 e 6). O excerto, porém, termina com a sinalização de nova perturbação: o arbítrio da polícia no quarto à frente (item 7) e contra um estudante que "não era criminoso, nem nada". Novamente o sujeito será intimidado, agora, pelo Estado brasileiro. 
A sanção - sob a forma de auto permissão - é perturbada pelo episódio extemporâneo ao querer, poder, saber ou dever do sujeito, e atua como antecipação de sua própria trajetória. Em síntese: não há paz para os que trabalham, nem para os que estudam no Brasil da ditadura.

Tanto em "CADA RATO TEM SEU PREÇO", quanto em "SETE ITENS" podemos observar como esse sujeito responde às situações de impotência (nãopoder-fazer) e de obediência (não-poder-não-fazer), afirmando sua independência (poder-não-fazer), seja pagando os meninos para infestar o cinema de ratos, seja fingindo ser humilde para o gerente, conforme o seguinte esquema modal:

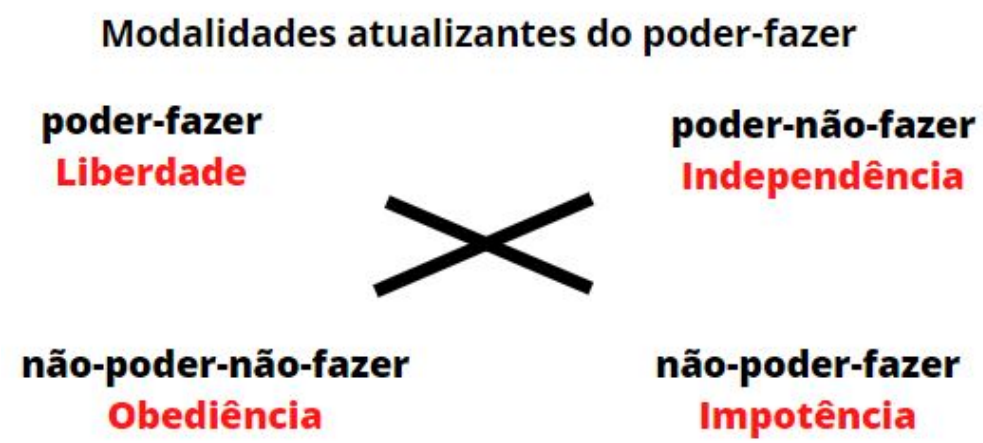

Ao longo do seu percurso, José será transformado por pressões diversas que limitam sua independência e liberdade, de necessidades básicas (sobrevivência, moradia, emprego) a acontecimentos políticos, passando por diferentes manipulações dos atores que o circundam (Átila, Rosa e Gê). Rosa, em particular, tem um papel central nas mudanças de estado do sujeito.

De modo geral, José passa de solteiro para casado, submetido à intimidação (medo de ficar sozinho), à tentação (prazer afetivo e sexual) e à provocação de Rosa que the cobra a performance de homem provedor. Porém, conforme tenta cumprir essa performance, em meio ao desemprego e a vários questionamentos que o assolam, José cai na contravenção, novamente em situação de obediência (não-poder-não-fazer) ante à opressão econômica, 
principal destinadora dos passos desse sujeito, denunciada por Loyola junto à opressão política.

O contexto político, por sua vez, intensificará o estado de opressão e de impotência do sujeito, na medida em que os serviços prestados ao Comuns e, em particular, seu contato e proximidade com Gê, tornarão José não um revolucionário - sua relação com a resistência à ditadura é marcada pela admiração em tons messiânicos que expressa pelo líder revolucionário -, mas um colaborador da guerrilha, prestando pequenos serviços remunerados, que o colocarão na rota da repressão política. A busca pela independência, objeto de valor ao longo de toda a trajetória desse sujeito, é negada a José. Em Zero, a conjunção entre sujeito e objeto de valor é impossível.

Tema recorrente ao longo de toda a obra, a ditadura militar pode ser evocada como no excerto acima, ou metaforizada, como veremos no excerto abaixo que trabalha com a isotopia temática da crucificação, em referência à violência impingida sobre os corpos, remetendo-nos à violação de direitos em curso no país:

\section{ENTREVISTA}

? Os Comuns, onde estão os Comuns.

Havia crucificados, porque ali era o campo dos crucificados.

? Comum. Crucifique-o.

\section{CRUCIFIQUE-O \\ CRUCIFIQUE-O}

Gritava a multidão.

\section{CRUCIFIQUE-O} CRUCIFIQUE-O

Gritava a multidão.

Indústria ganhava muito dinheiro com a concorrência das cruzes. De ferro, simples, com buracos por onde passavam os parafusos que atravessavam as mãos. $E$ aos domingos e aos sábados e feriados e dias santos, o povo sentava-se com cestas e fazia piquenine, observando os homens / e as mulheres / morrerem.

In hoc signo vinces.

(Zero: 272) 
Narrado em debreagem enunciva, e por um observador com focalização total, a cena acima se coloca enquanto enunciado enunciado, apagando as marcas da enunciação, e permitindo que a cena aconteça diante dos nossos olhos. Nela, dá-se a crucificação dos Comuns, reunindo duas isotopias figurativas - a crucificação de Cristo / os assassinatos da ditadura - e apresentada, tal como um espetáculo, em quatro atos que englobam:

(1) A prisão (? Onde estão) e a sentença (? Comum. Crucifique-o);

(2) A crucificação (assassinato) propriamente dita, construída a partir dos recursos visuais da linguagem verbal, com a inserção de duas cruzes no meio do texto, compostas pelos gritos da multidão: "CRUCIFIQUE-O".

(3) A euforização da crucificação (vantajosa para o setor industrial (vide o apoio da FIESP) e prazerosa para a população) construída discursivamente pela ironia;

(4) A referência a Constantino I - "In hoc signo vinces / com este sinal vencerás" - primeiro imperador romano a professar o cristianismo, que nos traz os responsáveis pelo martírio, neste jogo de espelhos, seja o Império Romano ou Estado militar.

No microcapítulo "ENTREVISTA", podemos identificar as isotopias em torno do cristianismo de outrora (Constantino I) e dos comunistas de agora, aproximados no mesmo percurso narrativo ("via crucis") que consiste em: desaparecimento / sentença / morte / ganho para as elites e prazer da multidão. Daí a hipocrisia desvelada, na medida em que os que se dizem cristão se regozijam, embebidos de ódio, com o sacrífico de homens e mulheres, tal como os romanos se regozijavam com o sacrifício dos cristãos de outrora. Importante destacar que em Zero, a revolução é permeada de isotopias que nos remetem à religião.

Neste caso, escancarando a hipocrisia da "família cristã brasileira" apoiadora da ditadura, em outros, estabelecendo paralelos explícitos entre Gê e Cristo, por meio de paródias a episódios bíblicos, ou entre a fé em Gê e a fé em Cristo, manifesta quando José cuida do revolucionário em sua casa. A crítica incide tanto sobre a perversidade da sociedade brasileira, que vibra com a morte 
daqueles que elege como inimigos, quanto sobre o messianismo revolucionário da esquerda.

Em vários momentos da obra, inclusive, a ditadura é tematizada. E partir de dados exagerados, como o anúncio de um toque de recolher às $21 \mathrm{~h} 34$; ou a presença de autofalantes nas ruas transmitindo o discurso dos generais etc. Tamanha precisão, evidentemente, atua como elemento hiperbólico, chamando a atenção do enunciatário, sob a forma do exagero, para os elementos compatíveis entre a ficção e a realidade, estabelecendo uma relação de metonímia em torno da experiência compartilhada (os vários toques de recolher da ditadura) entre enunciador e enunciatário.

De qualquer modo, não há padrões entre os capítulos e microcapítulos de Zero, o que existe é experimentação de possibilidades enunciativas e a costura de temas e figuras revestindo a intencionalidade crítica, irônica e/ou debochada de um enunciador que se reveste de diferentes narradores, assumindo várias possibilidades de focalização. Afinal, se em PanAmérica, nós tínhamos um mesmo narrador percorrendo distintos percursos temáticos, o que temos agora é um enunciador organizando discursos de diferentes narradores.

\section{- Relações transtextuais}

Composta como mosaico de pequenos fragmentos, organizados pelo percurso ficcional, a saga de José, Zero é também perpassado por uma vertiginosa quantidade de discursos referenciais, como podemos observar no excerto abaixo: 


\section{FRAÇÕES DO MELODRAMA COTIDIANO}

. Pesquisa feita por A. de Carvalho mostra que a manutenção das forças armadas custa a cada pessoa 9,10 dólares na Argentina, 18,53 dólares em Portugal, 24,60 na Itália, 31,13 em Cuba, 75,52 na Suíça, 79,45 na Inglaterra e 327,25 nos Estados Unidos.

. Eu lá quero saber.

"Ela murmurou: Oh!, que me importa! Que me importa!

Como podia ele falar em coisas tão fúteis, diante da dor imensa que transparecia no seu rosto lavado em lágrimas ardentes? A sua sensibilidade revoltou-se. Deu alguns passos para trás e perguntou com uma frieza que não pôde dissimular:"

Alta, magra, pele esbranquiçada, Esmeralda Claudino, 22 anos, contava como seu irmão Aparecido foi assassinado:

- Eram 11 horas, quando três homens chegaram perto dele no bar e pediram um cigarro. Ele não tinha, porque não fuma, e então começaram a bater nele. Ficou desmaiado, levei ele ao pronto-socorro da vila, lá meu irmão sumiu, ninguém sabe dele.

"Regina, que estava perto, docemente lhe tomou a mão um pouco crispada.

O Passado, de M. Delly (Les ombres)

Noticia de "Hora $H^{\prime \prime}$

Alma em flor, de M. Delly (La Jeune Fille Emmurese)

(Zero, p. 211)

Composto visualmente por duas partes: (1) a do texto, com distintos discursos distribuídos em seus parágrafos como se tratasse de um texto corrido, em acordo com o gênero romance; e (2) por notas laterais indicando a fonte, ou o hipotexto (texto A) de onde a informação foi extraída, atribuindo um caráter de veracidade à informação; o excerto acima é uma composição de discursos que, mesmo inseridos na narrativa, mantêm a coerção do gênero - da reportagem jornalística (regido pela função referencial) e do melodrama literário (regido pela função poética).

Em Palimpsestos: literatura de segunda mão (2010), Gerard Genette, aponta cinco tipos de transtextualidade, modos como um texto se enxerta em 
outro: intertextualidade, metatextualidade, arquitextualidade, hipertextualidade e paratextualidade, das quais é possível identificar no exemplo acima, a presença da:

(1) Intertextualidade, qualquer relação de referência, com ou sem aspas, que nos permite identificar a co-presença entre dois ou vários textos. No texto, a intertextualidade evoca a presença de dois gêneros de leitura e, mais que isso, dois gêneros de leitores, que nos remete a uma "fração do melodrama cotidiano" desse casal, cada qual sua literatura de interesse. No caso de Rosa, a citação de M. Delly33 (terceiro e quarto parágrafos) referenciada com aspas; e literalmente um texto dentro do outro, indicando-nos a leitura popularesca, vendida nas bancas e consumida pelas jovens brasileiras. No caso de José, podemos identificar duas reportagens e, pelo menos no caso de uma delas, atribuída ao jornal "Hora H", ambas referenciadas sem aspas, conforme as coerções da crônica jornalística. Os dois gêneros estão imbricados, como podemos ver, mas entre a reportagem policial e o estilo melodramático de $\mathrm{M}$. Delly há um forte contraste, revelando-nos, semanticamente, diferentes interesses entre o jovem casal de recém-casados.

(2) A paratextualidade relativa às relações que podemos inferir por meio do título, subtítulo, intertítulos, prefácios, posfácios, prólogos, notas marginais, de rodapé, de fim de texto etc., que Genette classifica de relações de paratextualidade. Em Zero, os elementos paratextuais não margeiam a obra simplesmente, em vários momentos, eles se tornam centrais à compreensão da narrativa, como se fosse necessário esgotar todas as possibilidades expressivas do objeto-livro. O excerto acima traz vários desses índices, a começar pelo título, que indica a presença de Rosa e José. Outra marca diz respeito às notas à direita, em particular a supressão da fonte da pesquisa citada no primeiro parágrafo, relativa aos custos das Forças Armadas, que podemos atribuir ao "Hora H", mas sem a certeza que temos em relação à correspondência das fontes nos demais trechos. A supressão é, inclusive, reforçada pela suspensão

33 M. Delly era como assinavam os irmãos Frédéric Henri Petitjean de la Rosiére e Jeanne Marie Henriette Petitjean de la Rosiére, escritores franceses que publicaram mais de uma centena de livros destinados às mulheres jovens. No Brasil, eles começam a ser publicados pela Companhia Editora Nacional, de Monteiro Lobato. (Wikipedia, acesso em 2019). 
dos dados relativos ao Brasil no parágrafo sobre a pesquisa, provocando o leitor a se perguntar, "e no Brasil, qual o custo das Forças Armadas por pessoa?"

(3) A hipertextualidade que é a relação entre um texto A (hipotexto) do qual brota um texto $B$ (hipertexto), sem que isso seja um comentário. Obras literárias que evocam outras obras, a hipertextualidade é uma espécie de bricolagem, "arte de fazer o novo com o velho"; e tem como vantagem a produção de "objetos mais complexos e mais saborosos do que os produtos fabricados" (Genette, 2010: 14). Neste sentido, podemos conceber a íntegra do capítulo Frações do Drama Cotidiano (e ele continua...) como um hipertexto composto por vários hipotextos extraídos, tal e qual, de duas reportagens jornalísticas e duas obras literárias.

(4) A arquitextualidade, que são relações que nos permitem, apesar de incontáveis experimentações, identificar Zero como romance; e cada um dos fragmentos acima citados conforme seus respectivos gêneros. Segundo Genette, essa é uma relação fundamental na medida em que o arquitexto cria o horizonte de expectativas do leitor e isso, naturalmente, irá influenciar a sua apreensão da obra.

(5) Uma última relação citada por Genette que não está presente neste excerto em específico, mas é utilizada à exaustão na obra, diz respeito à metatextualidade, que é a relação crítica por excelência, realizada por meio de comentários e análises. Em Zero, podemos observar sobre o metatexto a presença de um narrador intruso, em geral, com focalização total sobre os episódios, que comentará o andamento da trama, desautorizando os personagens, e antecipando acontecimentos da obra.

Loyola inclusive menciona o caráter experimental desse narrador:

Comecei a colocar ironias pelo meio. Criei notas de pé de página para contestar a mim mesmo. Era o autor olhando o autor, criticando, debochando, contestando, dizendo qual é? Nenhum outro livro brasileiro fez isso até hoje. Fui cortando, reescrevendo, recriando. Cheguei a mil laudas, continuei, cheguei a oitocentas, seiscentas, e parei em cerca de quinhentas e tantas (Brandão, 2010,p.16). 
Zero opera com todas as possibilidades de transtextualidade citadas por Genette, garantindo, por meio delas, tanto a heterogeneidade em termos de enunciação, pela justaposição de gêneros distintos, quanto a polifonia de pontos de vista, em termos semânticos.

Essa heterogeneidade oriunda das relações transtextuais é ainda mais intensificada no percurso conjuntural da obra, quando essas experimentações são potencializadas pelo sincretismo entre as linguagens verbal e visual.

\subsubsection{O eixo conjuntural}

Até aqui, nós pudemos observar as principais experimentações que incidem na narrativa multifacetada de Zero, a partir de excertos próprios do programa narrativo em torno do sujeito José. Paralela e independentemente, mas de modo imbricado a essa trajetória, há um outro percurso na obra, muito mais atado às marcas da referencialidade no plano de conteúdo que são inseridas por meio do jogo hipertextual, o que potencializa o contrato de veridicção entre enunciador e enunciatário. Essa é uma das dimensões da "ficção realidade" mencionada por Loyola, capaz conferir um caráter de "verdade" ao discurso, da mesma forma como as estratégias do discurso publicitário que pertencem ao regime referencial, e que visam "comprovar" o que é dito, e assim persuadir o enunciatário.

Esse eixo, mais "conjuntural" do que "ficcional", engloba várias séries temáticas que veremos a seguir. Trazendo o contexto e o arquitexto da obra, elas podem ser analisadas a partir de um conceito desenvolvido por Roland Barthes, em O Rumor da Língua (1957): o de discurso encrático e acrático. O primeiro diz respeito à caracterização de textos que reproduzem, de modo eufórico, discursos de poder. Esses textos teriam como contraponto, os discursos acráticos que os desafiariam. No percurso da intertextualidade inserido em Zero, é possível observar o jogo contínuo de oposição entre esses dois discursos. 
Grosso modo, o discurso encrático em Zero reverbera os seguintes discursos de poder: (1) o econômico, como a série de slogans publicitários disparados sobre o protagonista; (2) o religioso, desde a repressão sexual ao misticismo propriamente dito, passando pelo messianismo revolucionário; (3) o cultural, onde os valores da sociedade burguesa (família, casamento, propriedade) massacram a independência desse sujeito; (4) o discurso oficial do Estado, e aqui a crítica é categórica: o Estado só existe na vida de José, de Rosa e de Átila enquanto instrumento de repressão e redução de direitos.

Os discursos acráticos, por sua vez, dizem respeito à denúncia das mais diversas opressões que incidem sobre os atores principais e secundários da obra, como vemos abaixo, no capítulo "Gráfico do Operário Pedro", em exemplo cabal do descarte de corpos promovido pelo sistema capitalista:

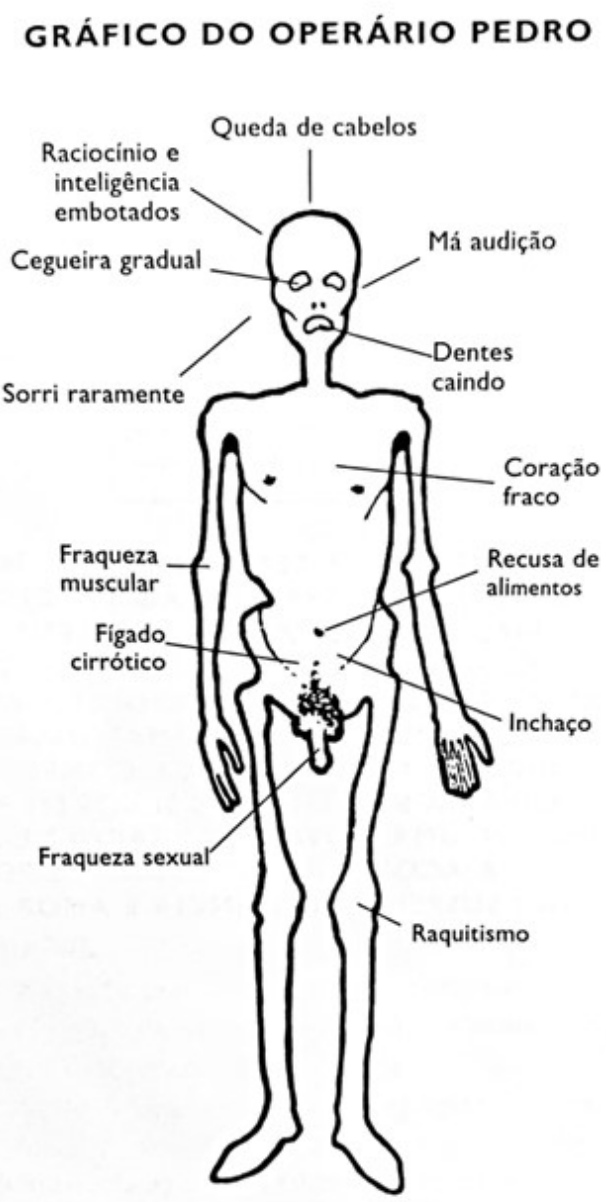

(Zero, p. 159) 
Em meio a tantos gráficos, onde somos apenas números, e cuja linguagem essencialmente numérica é capaz de naturalizar extremos, a junção da imagem e das legendas reconstrói nossa percepção do real, e nos coloca diante desse corpo massacrado pela exploração sistêmica, fadado ao descarte e à morte. Nisso consiste a força do sincretismo proposto por Loyola: em determinados momentos, não basta apenas ler, é preciso enxergar o limiar. Lamentavelmente, o gráfico não perde sua atualidade. Ele diz tanto aos miseráveis de outrora, quanto aos chamados "empreendedores" deste novo século: a massa de desassistidos que, no Brasil, caminha para um futuro sem direitos, inclusive, sem aposentadoria.

Outro exemplo de discurso acrático presente na obra pode ser visto abaixo:

\section{ADEUS, ADEUS}

Depois de ter sua biblioteca inteiramente confiscada e queimada pelo Governo 1, o sociólogo e pesquisador das origens do subdesenvolvimento nacional, Carlos Antunes, aceitou o convite de Yale para lecionar na famosa Universidade Norte-Americana. Deve embarcar dentro de 10 dias, se os advogados liberarem o seu passaporte.

(Zero, p. 114)

Adeus, Adeus é uma série, de um parágrafo no máximo, que tematiza o exílio e as perseguições políticas, vocalizando como o próprio nome diz, "adeus, adeus", a saída de intelectuais, artistas e cientistas do país. Ela perpassa o livro de ponta a ponta, em denúncia permanente do desmantelamento da inteligência brasileira, como se vê no exemplo acima, por meio de confisco e queima de bibliotecas pessoais.

Além desta, são comuns outras séries na narrativa, em geral, reunidas em torno de um mesmo título ou estilo de enunciação, por exemplo, o Pensamento do Dia que, no excerto abaixo, traz o mito do enriquecimento individual, exemplo cabal de discurso encrático disseminado em slogans publicitários como o das letras de câmbio abaixo: 


\section{PENSAMENTO DO DIA \\ É borrível ser pobre \\ Compre boje mesmo letras de câmbio Idem, as que duplicam dia a dia o seu dinbeiro.}

(Zero, p. 162)

Inscrições de Privada são outro exemplo de modalidade seriada. Em geral quadrinhas (trova simples) bem-humoradas, identificadas visualmente pela tipografia que emula a escrita cursiva, próprias de inscrições em banheiros públicos, inserindo dentro de um romance e da literatura, um gênero de escrita absolutamente marginal:

Inscricoes de privada:

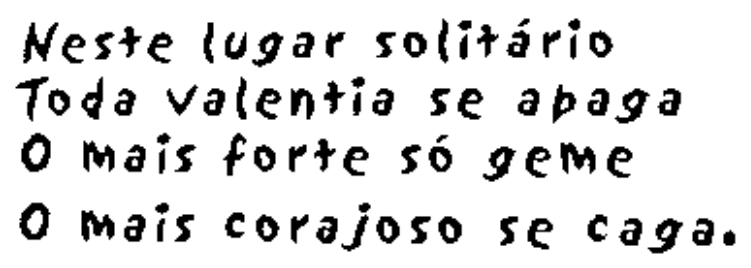

(Zero, p. 114)

Assumindo espécie de performance acrática, as Inscrições de Privada, assim como Adeus, Adeus e Pensamento do Dia são introduzidas ao registro literário, permeando o gênero "romance" de estilo, sabedoria e humor populares $A$ democratização é completa: diversos tipos de discursos e diferentes modos de enunciação detêm o mesmo peso narrativo. Acráticos são, também, as unidades de temática erótica e sexual que, em geral, trazem temas tabus e marginais, em total libertação das repressões que incidem sobre os corpos. 


\section{- Entre o verbal e o visual}

Em Zero, a ilusão de realidade é construída tanto em termos de plano de conteúdo, quanto no de expressão, por meio da investigação das possibilidades expressivas do signo verbal e por sua articulação com a semiótica visual, construindo uma espécie de "prosa concreta", capaz de combinar estímulos orais, verbais e visuais na expressão de sua verdade estética, histórica e humana. Dotando o plano de expressão de ampla diversidade expressiva, Loyola possibilita o jogo entre o ficcional e o não-ficcional, o crível e o incrível, lançando-nos no espaço fronteiriço do sincretismo entre duas semióticas distintas: a verbal (textos) e a visual (imagens). Esse processo é orientado por três princípios:

(1) Ausência de hierarquias entre ambas as semióticas. Imagem e texto equivalem em grau de importância, e longe de serem meras ilustrações, as imagens em Zero são tão fundamentais quanto o texto para a compreensão da obra;

(2) Multiplicidade de gêneros discursivos, dispostos lado a lado, garantindo no plano de expressão a mesma polifonia discursiva que observamos no plano de conteúdo;

(3) Construção de um percurso verbivocovisual da narrativa, desde o trabalho tipográfico à ilustração propriamente dita, como se fosse preciso esgotar todas as possibilidades expressivas da obra.

O enxerto abaixo, por exemplo, é forte exemplo de discurso acrático, a partir da inserção do gênero poesia na obra, em particular, a poesia concreta, conferindo fisicalidade, por meio da linguagem verbal, às violações do Estado contra a população civil. Inscrito no capítulo Frações do drama cotidiano, o poema abaixo diz respeito à sessão de tortura contra Átila, melhor amigo de José: 


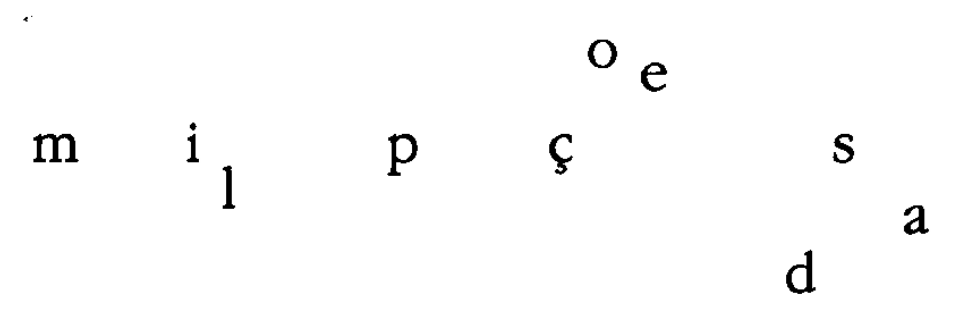

(Zero, p. 377)

O parágrafo "mil pedaços" é construído pela desarticulação das letras e fonemas, estabelecendo o paralelo despedaçamento da palavra/ desmembramento de corpos de Átila, em plena correlação entre os planos de conteúdo e de expressão. Vale destacar que, ao longo da obra, o mesmo recurso será repetido, marcando a violência em vários momentos da obra.

Essa espacialização do discurso verbal também é realizada pela disposição visual das frases, conforme o excerto abaixo:

Obedeça à sinalização e viaje tranquilo.'

José e Rosa estão viajando para o interior, para que José peça a mão de sua noiva. Segundo normas estabelecidas de nossa sociedade.

\begin{abstract}
LIMITE DO MUNICÍPIO DE FILHODA EM FILHODA CONSULTE O SEU REVENDEDOR FORD AUTORIZADO O MELHOR RESTAURANTE DA REGIĀO: JECA TATU OFERECE O MELHOR VIRADO VOCÉ ESTÁ ENTRANDO EM FILHODA: O MUNICÍPIO MAIS PROGRESSISTA DO PAIS SEIS PRESIDENTES NASCERAM NESTA CIDADE AS MELHORES FACULDADES DE MEDICINA E DIREITO SEJA BEM-VINDO - SEJA UM DOS NOSSOS VOLKS I.600 PONTO DE CHARRETES DA ESTAÇĀO VISITE A COLOSSAL QUERMESSE PRO-OBRAS DA IGREJA SANTO ANJO DO SENHOR
\end{abstract}

(Zero, p. 171)

A viagem de José à cidade de Rosa é descrita verbal e visualmente, por meio da construção visual da estrada a partir de slogans e frases escritos em outdoors e placas lidas pelos personagens (e por nós, lado a lado deles) conforme o carro avança em direção ao centro de Filhoda, indicada pela seta. É 
possível observar neste excerto, a total correção entre os planos de expressão e conteúdo, na construção de uma prosa concreta.

Além das possibilidades visuais do discurso verbal, narrativa também abrange desenhos, como o corpo de Pedro visto anteriormente, ou as mãos de José desenhadas no excerto abaixo, criando efeito de radical tridimensionalidade:
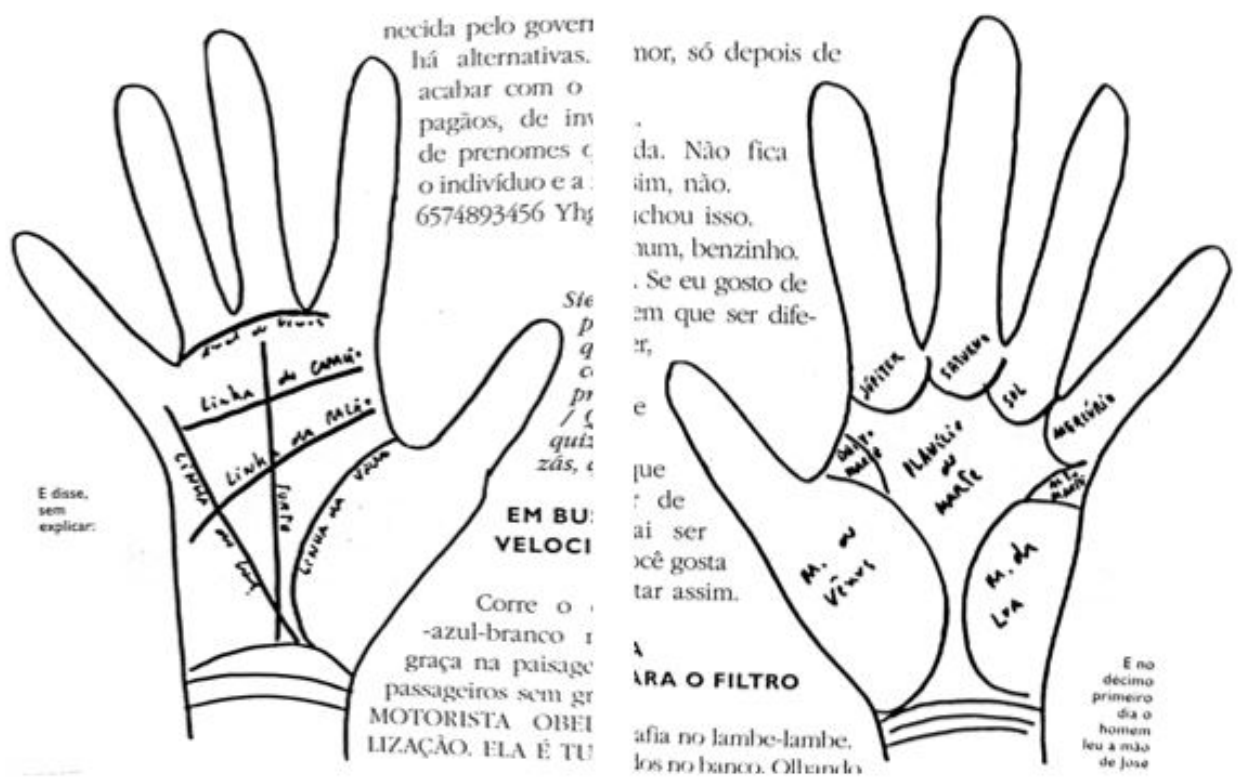

(Zero, p. 169-170)

Desenhada na frente e no verso da folha, no mesmo tamanho, a mão de José cria a ilusão de tridimensionalidade, e surge em sua inteireza diante do enunciatário. O efeito de realidade é imediato. A inserção do registro visual promove, inclusive, a passagem do actante "ele", do espaço "lá" e do tempo "alhures", que constituem o processo de debreagem enunciva, comum em narrativas convencionais e em terceira pessoa, para a relação "eu/tu", o espaço "aqui" e o tempo "agora", característicos do processo de debreagem enunciativa, resultando em total aproximação entre sujeito e enunciatário que tal como o curandeiro mencionado no excerto, também pode ler as mãos do protagonista da obra. 
Esse movimento contínuo de aproximações e distanciamentos entre o enunciador e enunciatário, combinando múltiplas possibilidades expressivas, é próprio do imbricamento das semióticas verbal e visual. Cada fragmento do drama humano em Zero acena para uma forma distinta de expressão do real, como se o romance precisasse, a todo momento, apresentar as provas de sua existência. O resultado é uma composição visceralmente referencial e tridimensional, em consonância com as necessidades expressivas em um contexto de sucessivos silenciamentos.

A realidade nunca é construída de modo isento em um discurso e, em particular, no discurso poético. Poderíamos, inclusive, citar diversos romances que constroem a ilusão de realidade denunciando as contradições de sua contemporaneidade, a começar pela crítica visceral de Machado de Assis contra a burguesia parasitária do Rio de Janeiro, em Memórias Póstumas de Brás Cubas (1881); a denúncia visceral que Patrícia Galvão, a Pagu, faz sobre o périplo das mulheres operárias em Parque Industrial (1933); chegando ao cotidiano dos trabalhadores em São Paulo tão bem retratado por Lilia Guerra em Perifobia (2018).

Neste sentido, Zero traz imensa contribuição, afinal, sua narrativa não é simplesmente uma abordagem da opressão, mas a realização poética de diferentes violências na linguagem verbal, por meio da composição de um mosaico de excertos que reconstroem, de modo verbivocovisual, a carnificina propalada pela máquina de extermínio do Estado militar, pela desigualdade social e de oportunidades e, também, pela moralidade reacionária da "família, tradição e propriedade". Ao mesmo tempo, enquanto "catálogo" de experimentações com a linguagem verbal e visual, Zero é um deleite para qualquer apreciador do trabalho poético com a linguagem.

Ao reagir ao silenciamento de seu contexto histórico, a obra se impõe como libelo da liberdade de expressão, tanto em termos do conteúdo que apresenta, a saga de um rapaz que tenta defender sua independência e liberdade, em um contexto marcado pela exploração do homem pelo homem; quanto em termos de expressão, a partir de três experimentações essenciais: 
1. Heterogeneidade enunciativa que engloba vários modos de enunciação, focalização e actorizalização narrativa, desde a enunciação enunciada, enunciado enunciado, enunciação reportada, focalização parcial interna, parcial externa e total do observador, actorialização por debreagem enunciva e enunciativa seja da enunciação seja do enunciado;

2. Relações transtextuais, seja a intertextualidade, metatextualidade, hipertextualidade, arquitextualidade ou paratextualidade, que permitem a justaposição de diferentes gêneros textuais, criando uma composição de "textos de segunda mão" ou hipertextos, que carregam as coerções de gênero do texto de origem (ou hipotexto);

3. Sincretismo entre as linguagens verbal, oral e visual, na constituição de uma "prosa concreta", combinando efeitos de sentido próprios das linguagens visuais ou verbais, em um percurso que abrange desde o cuidado com a tipografia até a inserção de imagens propriamente ditas. De um ponto a outra, Zero trabalha todas as possibilidades.

A partir desses três procedimentos temos a construção referencial da narrativa que busca denunciar de todas as formas (linguagem verbivocovisual) e por todos os ângulos (heterogeneidade enunciativa) possíveis, o grito dos que são cotidianamente reduzidos a "zero" nos gráficos e estatísticas dos donos do poder econômico, político e das forças de opressão. 


\subsection{O regime substancial em Riverão Sussuarana}

Em 1978, quando Riverão Sussuarana foi publicado, Glauber Rocha já era reconhecido entre seus pares e por grandes nomes do cinema mundial, capturados por obras-primas como Barravento (1962), Deus e o Diabo na Terra Sol (1964), Terra em Transe (1967), O Dragão da Maldade contra o Santo Guerreiro (1969)34. Nascido em Vitória da Conquista (BA), em 1939, Glauber foi idealizador e um dos principais fomentadores do Cinema Novo, movimento artístico que entre 1960 e 1970 revolucionou a linguagem cinematográfica brasileira, levando o povo e sua brutal realidade às telas de cinemas do país e dos principais festivais do mundo.

Com apoio dos Centros Populares de Cultura (CPC), pontos de cultura fomentados pela União Nacional dos Estudantes (UNE), o Cinema Novo teve público cativo no circuito universitário em consonância com questões políticas, filosóficas e estéticas levantadas pelo neorrealismo italiano (Ladrões de Bicicleta, Milagre em Milão), pela nouvelle vague francesa (Hiroshima, meu amor, Acossado, Jules e Jim), pelo cinema de montagem de Eisenstein (Encouraçado Potemkin) e outras propostas estéticas que abordaram a Sétima Arte como instrumento de investigação e contestação do real.

No Brasil, dessa empreitada artística e politicamente revolucionária, juntamente com Glauber, participaram Nelson Pereira dos Santos (Rio 40 Graus, Vidas Secas, Como era gostoso o meu francês), Rui Guerra (Os Cafajestes, Erendira, Os fuzis), Cacá Diegues (Bye, Bye Brasil, Ganga Zumba, A Grande Cidade), Leon Hirszman (A Falecida, Eles não usam Black-tie, $A B C$ da Greve), Paulo César Saraceni (O Desafio, Integração Racial, A Casa Assassinada),

\footnotetext{
34 Barravento foi premiado no Festival Internacional de Cinema de Karlovy Vary na Tchecoslováquia em 1964; Deus e o diabo na terra do Sol conquistou o Grande Prêmio no Festival de Cinema Livre da Itália e o Prêmio da Crítica no Festival Internacional de Cinema de Acapulco; Terra em Transe conquistou o Prêmio da Crítica do Festival de Cannes, o Prêmio Luís Buñuel na Espanha, o Grande Prêmio do Júri da Juventude de Melhor Filme do Festival Internacional de Cinema de Locarno e o Golfinho de Ouro de melhor filme do ano, no Rio de Janeiro. O Dragão da Maldade contra o Santo Guerreiro recebeu prêmio de melhor direção no Festival de Cannes e, outra vez, o Prêmio Luiz Buñuel na Espanha (Wikipedia, online, disponível em < https://pt.wikipedia.org/wiki/Glauber Rocha $>$ ).
} 
Eduardo Coutinho ( $A B C$ do Amor, Cabra Marcado para Morrer, O Homem que Comprou o Mundo), Roberto Santos (O grande momento, A Hora e a Vez de Augusto Matraga) e tantos outros que, com "uma câmera na mão e uma ideia na cabeça", construíram um cinema fortemente inventivo inclusive para driblar ausência de recursos, optando, por exemplo, por filmagens em cenários originais (rua, praça, estádio de futebol).

Reunidos por essas dificuldades iniciais, afinidades pessoais e, sobretudo, pelo compromisso ético e estético de expor os conflitos sociais e o povo brasileiro, sem maquiagem, no primeiro plano das telas de cinema, esses cineastas conquistaram o mundo, ganhando prêmios nos grandes festivais internacionais (Cannes, Montreux, Berlim, Gênova), com sua versão sobre os dramas, sonhos e cotidiano das populações situadas na periferia do capitalismo.

Neste processo, conta Maurício Cardoso (História-USP), Glauber foi fundamental no estabelecimento de relações e/ou estreitamento de vínculos com cineastas, produtores e críticos de outros países, empreendendo "extenso campo de guerra cultural, envolvendo a produção e distribuição de filmes, a elaboração obsessiva de textos na imprensa, a publicação de livros e os contatos e viagens internacionais" (Cardoso, 2011, online).

Em 1965, um ano antes do incêndio e fechamento da UNE pela ditadura, esses cineastas fundaram duas entidades: a produtora Mapa Filmes e a distribuidora Difilm, que tiveram em Glauber "mais que um socio-fundador, um combatente de primeira hora" em defesa da atuação do movimento em três frentes principais:

A primeira, mantendo a convicção de que uma nova linguagem exigia uma nova pedagogia das imagens, capaz de retirar o espectador da passividade do cinema norte-americano; a segunda, defendendo uma política de Estado que protegesse - cinema nacional contra a voracidade de Hollywood; e, finalmente, uma terceira frente que o conduzia às estratégias no mercado cinematográfico (Cardoso, 2011, online, grifos nossos). 
Após o Al-5, essa efervescência seria interrompida. Sem condições de permanecer ou de produzir no país, Glauber e vários outros cineastas partiram em autoexílio. É neste contexto, entre 1972 e 1977, que ele escreverá o seu primeiro romance, a "desnovela" (assim tratada por ele) Riverão Sussuarana que será marcada por uma tragédia pessoal na vida do autor, o falecimento de sua irmã, Anecy Rocha em 1977. Antes, porém, de entrarmos nessa desnovela e para maior compreensão das experimentações propostas na obra, necessário se faz um breve comentário sobre dois manifestos do autor, Estética da Fome e Estética do Sonho, que nos permitem vislumbrar o horizonte de sua utopia.

\title{
- Da Fome ao Sonho
}

Apresentado durante a Resenha do Cinema Latino-Americano de 1965, em Gênova, na Itália, Estética da Fome trabalha com a oposição semântica opressão vs. liberdade, tematizada nas oposições colonizados vs. colonizadores, países desenvolvidos vs. países subdesenvolvidos, próprias dos discursos políticos do período. Nesse texto, o cineasta denuncia, de forma contundente, as relações de exploração no Terceiro Mundo, e sob o ponto de vista do explorado, trazendo um diagnóstico premonitório sobre a América Latina:

\begin{abstract}
A América Latina, inegavelmente, permanece colônia, e o que diferencia o colonialismo de ontem do atual é apenas a forma aprimorada do colonizar: e, além dos colonizadores de fato, as formas sutis daqueles que também sobre nós armam futuros botes. O problema internacional da América Latina é ainda um pouco de mudança de colonizadores, sendo que uma libertação possível estará sempre em função de uma nova dependência. (Glauber, 1965, online).
\end{abstract}

Apontando o aprisionamento latino-americano, sua dependência cultural e econômica; e a violência das relações hierárquicas que estruturam sociedades colonizadas como a nossa, Glauber apresenta a problemática da fome no continente não apenas como um "sistema alarmante", mas como "o nervo", a estrutura das sociedades latino-americanas. "Nossa originalidade é nossa fome 
e nossa maior miséria é que esta fome, sendo sentida, não é compreendida", dispara diante de um público essencialmente composto pelos colonizadores (os europeus) que, em sua avaliação, não compreendem e se o fazem "não sentem" os reais problemas dessa América Latina condenada à miséria.

Por isso, afirma, "o Cinema Novo narrou, descreveu, poetizou, discursou, analisou, excitou os temas da fome", trazendo uma "galeria de famintos" que the imprimiram o caráter de "miserabilismo" em oposição ao cinema digestivo, composto pelos "filmes de gente rica, em casas bonitas, andando em automóveis de luxo". O discurso que parte de feroz crítica às desigualdades culmina em grito de guerra:

Do Cinema Novo: uma estética da violência antes de ser primitiva é revolucionária, eis o ponto inicial para que o colonizador compreenda a existência do colonizado: somente conscientizada de sua possibilidade única, a violência, o colonizador pode compreender, pelo horror, a força da cultura que ele explora. Enquanto não ergue as armas, o colonizado é um escravo: foi preciso um primeiro policial morto para que o francês percebesse um argelino (ibidem, grifos nossos)

A partir daí, Glauber semeia o movimento, apontando-o como "fenômeno dos povos novos e não uma entidade privilegiada do Brasil", que continuará germinando onde e enquanto houver alguém disposto a "filmar a verdade"; a enfrentar "os padrões hipócritas e policialescos da censura intelectual" e "o comercialismo, a exploração, a pornografia, o tecnicismo"; e a "pôr seu cinema e a sua profissão a serviço de causas importantes do seu tempo". Um artista, portanto, que fundará sua escritura tendo como base um ideário de verdade, de liberdade e de consciência histórica, combatendo "a mentira e a exploração" do cinema industrial, em busca de filmes capazes de "despertar no público a consciência de sua própria miséria" (Ibidem, 1965).

Seis anos e um Al-5 depois, essas ideias serão atualizadas em outro manifesto, A Estética do Sonho, apresentado em 1971 na Columbia University, nos Estados Unidos. Nesse novo manifesto, Glauber acusa a intolerância da direita e dos grupos sectários de esquerda, defendendo que "o artista deve manter sua liberdade diante de qualquer circunstância", afinal, "somente assim 
estaremos livres de um tipo muito original de empobrecimento: a oficialização que os países subdesenvolvidos costumam fazer de seus melhores artistas".

Para Glauber, arte revolucionária será aquela capaz de nos libertar da "razão conservadora", presente tanto no sistema cultural da direita quanto no da esquerda. No primeiro caso, "razão da ordem e do desenvolvimento" que tem na tecnologia o "ideal medíocre de um poder que não tem outra ideologia senão o domínio do homem pelo consumo". No segundo, o paternalismo em relação às massas pobres, transformando "a razão do povo" na razão da burguesia sobre o povo. A razão da esquerda é herdeira da razão revolucionária da burguesia europeia, daí que

a colonização, em tal nível, impossibilita uma ideologia revolucionária integral que teria na arte sua expressão maior, porque somente a arte pode se aproximar do homem na profundidade que o sonho desta compreensão possa permiti-lo (ibidem).

A partir daí, somente a arte capaz de romper com os racionalismos colonizadores poderá ser uma arte revolucionária. Para Glauber, é uma falácia responder a razão opressiva com a razão revolucionária, afinal, "a revolução é anti-razão que comunica as tensões e rebeliões do mais irracional de todos os fenômenos que é a pobreza", e cuja dimensão "nenhuma estatística neste mundo poderá comunicar", afinal,

a pobreza é a carga autodestrutiva máxima de cada homem e repercute psiquicamente de tal forma que este pobre se converte num animal de duas cabeças: uma é fatalista e submissa à razão que o explora como escravo. A outra, na medida em que o pobre não pode explicar o absurdo de sua própria pobreza, é naturalmente mística (ibidem).

Diante disso, para que o colonizado possa abalar as estruturas de sua própria dominação, é preciso que a razão revolucionária da esquerda ceda lugar à mística revolucionária. A crítica é direta: a razão revolucionária, impregnada do paradigma burguês, enxerga o misticismo como "irracionalista e o reprime à 
bala", porque "tudo que é irracional deve ser destruído, seja a mística religiosa, seja a mística política":

A revolução, como possessão do homem que lança sua vida rumo à ideia, é o mais alto astral do misticismo. As revoluções fracassam quando esta possessão não é total, quando o homem rebelde não se libera completamente da razão repressiva, quando os signos da luta não se produzem a um nível de emoção estimulante e reveladora, quando, ainda acionado pela razão burguesa, método e ideologia se confundem a tal ponto que paralisam as transações da luta. Na medida em que a desrazão planeja as revoluções a razão planeja a repressão. As revoluções se fazem na imprevisibilidade da prática histórica que é a cabala do encontro das forças irracionais das massas pobres. A tomada política do poder não implica o êxito revolucionário (ibidem, grifos nossos).

Se a razão é o que reprime e a desrazão o que liberta, cabe ao artista "tocar, pela comunhão, o ponto vital da pobreza que é seu misticismo, única linguagem que transcende ao esquema racional da opressão" porque "o irracionalismo liberador é a mais forte arma do revolucionário". Glauber recupera assim duas mitologias: (1) a origem comum latino-americana, defendendo que nossas raízes índias e negras "devam ser compreendidas como única força desenvolvida deste continente", porque "nossas classes médias e burguesias são caricaturas decadentes das sociedades colonizadoras"; (2) a compreensão da cultura enquanto rebelião popular, unindo-se à tradição literária que compreende o binômio arte-política, cultura e luta social como via indissociável:

A cultura popular não é o que se chama tecnicamente de folclore, mas a linguagem popular de permanente rebelião histórica. $O$ encontro dos revolucionários desligados da razão burguesa com as estruturas mais significativas desta cultura popular será a primeira configuração de um novo significado revolucionário (...) Arte revolucionária deve ser uma mágica capaz de enfeitiçar o homem a tal ponto que ele não mais suporte viver nesta realidade absurda. Esta raça, pobre e aparentemente sem destino, elabora na mística seu momento de liberdade. Os Deuses Afro-índios negarão a mística colonizadora do catolicismo, que é feitiçaria da repressão e da redenção moral dos ricos (ibidem). 
A estética do sonho defende a dupla rebelião - cultura popular e mítica revolucionária -, expressa em $A$ ldade da Terra (1980), um dos filmes mais experimentais de Glauber, que encerra o ciclo da terra iniciado por Deus e o Diabo na Terra do Sol (1964) e Terra em Transe. Neste filme, é trabalhada a mítica dos Quatro Cavaleiros do Apocalipse, apresentando várias versões de Cristo interpretadas por Antônio Pitanga, Geraldo Del Rey, Maurício do Valle, Jece Valadão e Tarcísio Meira. Apesar da crítica favorável na França, o filme ganhou duras críticas na Itália, em 1980, durante o Festival de Veneza, levando à contundente manifestação do cineasta contra o evento.

Como atesta Ismail Xavier, em $A$ invenção do estilo em Glauber Rocha (2011),

Para Glauber, a mudança social se vale de uma energia que não vem apenas da ideologia no sentido clássico, mas envolve um gesto de revolta que brota da vivência, da dor e das pulsões. Nessa ótica, o cinema, pelo que é, adquire uma posição estratégica e pode realizar o potencial subversivo dos conteúdos subterrâneos que circulam na sociedade, desde que seja capaz de compor o grande teatro condensado no corpo vivo, esse que sofre os efeitos da estrutura de classes e da dominação colonial. (Xavier, 2011, p. 25)

No Brasil, a recepção também foi negativa. O mesmo, aliás, ocorreria em relação à Riverão Sussuarana, único romance do autor, tão pouco comentado que, passados mais de quarenta anos de sua publicação, é praticamente desconhecido, inclusive, pelo público especializado em Literatura.

Lançado em 1978, um ano após a morte da irmã de Glauber, Anecy Rocha, Riverão expressa na linguagem verbal, as duas estéticas, da fome e do sonho, movimentando verdadeiro catálogo de referências culturais, políticas, históricas; entremeado pelas tragédias pessoais do autor e pelo elogio profanador a "mestre Guima", o "Embaixador Guimarães Rosa", transformada personagem da obra. 


\subsubsection{Glauber Rosa e Guimarães Rocha}

Como quem pede benção, Glauber se embrenha nos caminhos da Literatura, enunciando admiração e proximidade com o escritor mineiro, Guimarães Rosa. A trama propriamente dita é antecedida por um artigo do cineasta, impresso nas primeiras páginas do livro, referente ao avanço das traduções de Rosa no exterior. Daí segue a história do encontro de ambos no Festival em Gênova, quando da apresentação de Estética da Fome; e em sequência, misturando ficção e realidade, escritor e cineasta já estão absorvidos pela trama. É quando Rosa apresenta Glauber, como "amigo" e "pessoa de confiança", ao Comandante da caravana de jagunços, explicando ter convidado o cineasta para ajudá-lo em reportagem encomendada por O Cruzeiro, sobre a saga de Riverão Sussuarana, jagunço acusado de ter matado um parlamentar na Bahia.

A Glauber caberá, portanto, ajudar Rosa na reportagem de jornal, relatando os principais acontecimentos da caravana. O hipertexto é claro: remete-nos a Os Sertões de Euclides da Cunha, a obra-prima da mítica sertaneja, escrita como reportagem ao jornal O Estado de S. Paulo, em 1922, sobre a Revolta de Canudos. Agora, Rosa e Glauber partem em missão jornalística, seguindo pelas trilhas e atmosfera desse sertão, permanentemente revisitado, ao lado de cangaceiros como Ângelo Mauro, mais conhecido como Anjo Mau de Garanhuns e Pernambuco; de "Linda”, filha de Diadorim e Riobaldo, outro hipertexto a partir de Grande Sertão: Veredas; de seres mágicos como a cigana Escarlate e o papagayo Luiz, cujos conselhos, além de divertirem, influenciam as decisões do destemido Riverão Sussuarana.

Juntos, portanto, como personagens da trama, Rosa e Glauber buscarão, ao longo do romance, uma entrevista com Riverão Sussuarana, o cangaceiro que inspira o título do romance, e cujo nome acena a dois monumentos da literatura moderna e contemporânea: Finnegans Wake (1939) relembrado no termo Riverão; e Grande Sertão: Veredas (1956) em Sussuarana.

Em “Glauber Rosa e Guimarães Rocha” (Glauber, 2012), texto complementar à última edição da obra, o professor Jair Tadeu da Fonseca 
(Teoria da Literatura - UFSC) relaciona "Riverão" à palavra-valise riverrun que abre o romance de James Joyce, marco absoluto da literatura experimental "riverrun, past Eve and Adam's, from swerve of shore to bend of bay, brings us by a commodius vicus of recirculation back to Howth Castle and Environs" -, "riocorrente" conforme tradução de Augusto de Campos 35. "Provável corruptela de ribeirão", aponta Fonseca, "riverão reúne a "recorrência temporal e espacial, de fluxo, de circularidade", englobando "river (rio) e verão (estação do ano e futuro do verbo ver)", "espaço e tempo em movimento" (Fonseca, 2012, p. 238).

Costurando fatos e referências do mundo real, com cenas e referências do mundo ficcional, além da menção a Os Sertões e Finnegans Wake, a obra é um diálogo contínuo com a literatura de Rosa, em particular, o épico Grande Sertão: veredas, a começar pelo título, enunciando o território sertanejo dessa onça-suçuarana e o seu deserto, o Liso do Suçuarão.

\section{- Vocabulário autoral}

Enunciada duplamente, e deste o título da obra, a filiação experimental irá se expressar no plano de expressão, por meio da subversão do código linguístico, na construção de um vocabulário autoral, dotado de morfologia própria, por meio de

(1) Acento diferencial ou ausência de acentuação;

(2) Troca do "i" por "y"/ "s" por "z"/ "c" por "k"/ "j" por "g"/ "z" ou "ç" por "s" ("geito", "economisando", "dansarinos");

(3) Grafia de palavras conforme elas são pronunciadas (mulhé, milho, cumê);

(4) Incorporação de outros idiomas (tu eres, this is paradise) em consonância com a antropofagia Oswaldiana;

(5) Uso de palavras-valise, em geral neologismos constituídos a partir da junção de dois morfemas, por composição ou aglutinação ("sinceradimiração", "dedicaligrafado").

35 riocorrente, depois de Eva e Adão, do desvio da praia à dobra da baía, devolve-nos por um commodius vicus de recirculação de volta a Howth Castle Ecercanias (Tradução de Augusto de Campos) 
A primeira página do romance agrega várias dessas experimentações que podemos notar abaixo:

$1100 \begin{aligned} & \text { Ybrahym Sued \& Jacyntho de } \\ & \text { Thormes falavam do escritor di- } \\ & \text { plomata Joäo Guimarāes Rosa }\end{aligned}$ myneyro publicado pela Editôra JOSÉ OLYMPIO de grandes autores brazyleyros como José Lins do Rego, Graciliano Ramos, Carlos Drumond de Andrade: "SAGARANA", "CORPO DE BAILE", "GRANDE SERTÄO: VEREDAS" na juscelinismoida Bahya Era diretor do "Suplemento Letras? Artes do Dyaryo de Notycyas" e escrevi na coluna "Quarto Mundo", terceira pagina, artigo Joyce lembrando superioridade Villa Lôbos - Bach/ Beethoven/ Wagner/Strawinsky \& Portynary - Delacroix/Goya/Gaughin/ Picasso... recebo meses depois no Jornal o livro "PRIMEIRAS ESTORIAS" dedicaligrafado em forma

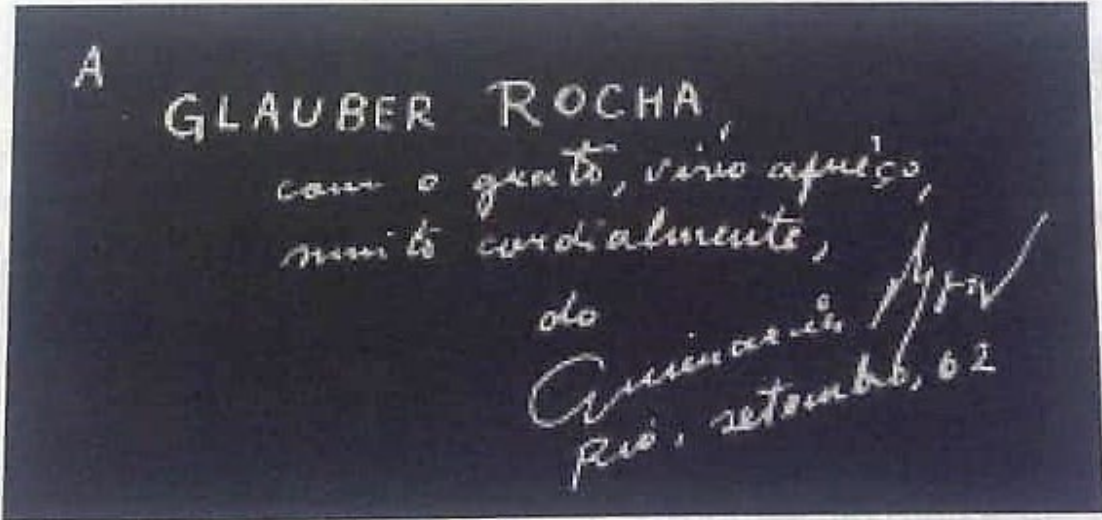

e pedi minha

amiga Dale pra encardenar o volume, surpreso pelo fato do Mestre Brazyleyro de Letras, conhecendapenas um artigo do conquystense que falava bem mas lera mal sua obra, expressar grande sinceradmiração.

(Riverão, p. 09)

Esse estranho vocabulário parte da capacidade de uma única letra de representar mais de um fonema, por exemplo o "s" em casa soa como [ Z ], equivalente ao nosso "z"; já em "saca", o "s" soa como [ S ]; ou, pelo contrário, de um mesmo fonema como [ I ] ser representado por mais de uma letra, como “i” ou "y", vistos em "Brazyleyro", "conquystense", "myneyro". A partir dessa propriedade fonética, Glauber irá construir novo léxico, partindo das unidades 
mais básicas do sistema língua, as letras do alfabeto, ao qual introduz o uso corrente das letras "k", "y" e "w" que, em geral, marcam na língua portuguesa a presença de línguas estrangeiras.

Em Riverão, essas subversões serão usadas em vários momentos, mas em particular na descrição de nomes próprios (pessoas, obras, instituições) ou de localidades. A incorporação desse traço "estrangeiro" não se dá apenas sob viés da denúncia contra o imperialismo, um discurso presente em toda escritura cinematográfica de Glauber e, em especial, no plano de conteúdo de Riverão. Ela atende a um esgarçamento das possibilidades expressivas da própria língua, remetendo ao "universalismo" da cultura e ao canibalismo antropofágico.

As regras ortográficas são subvertidas conforme os aspectos prosódicos, ou seja, de acordo com a predominância do oral sobre o verbal. É assim que o “j” será trocado pelo "g" em "geito"; o "z" pelo "s" em "economisando"; edificando essa língua mastigada, praticada pelo povo, em geral, impedido de participar das regras do sistema linguístico, compartilhado somente pelos que podem ter estudo. Aliás, entre os jagunços de Riverão, poucos têm. Essa demarcação social, transformada em expressão artística, dá origem à estranha grafia, permitindo-nos apreender, por meio desse estranhamento, as características prosódicas do signo verbal.

Trata-se, também, de uma linguagem fortemente autoral - inclusive, utilizada em outros textos do autor --, composta por experimentações que têm como principal efeito de sentido o predomínio da prosódia sobre a escrita, do específico sobre o universal, ou em termos saussurianos, da "fala" sobre a "língua", por meio de subversões das normas instituídas. As combinações prosódicas e as inovações desse vocabulário são responsáveis pelo primeiro estranhamento gerado por essa linguagem experimental, em termos de plano de expressão da obra.

Ao contrário do que vimos em Zero, o sincretismo entre verbal e visual será muito pouco utilizado em Riverão, salvo o bilhete de Rosa visto acima, em letra cursiva e com fundo em negrito, impresso na primeira página, que atua como testemunho e prova da proximidade entre narrador e escritor, interferindo no fazer-crer do leitor. De modo geral, a linguagem verbal é o território onde as 
experimentações acontecem na obra, em contínua problematização de regras e códigos da língua portuguesa, orientados pelos aspectos prosódicos.

Um segundo impacto diz respeito à alternância entre gêneros na narrativa (diário, comentário crítico, conto, poema, teatro, artigo etc.), em particular, a novela e o diário, influindo no "horizonte de expectativas" do enunciatário. No entanto, em Riverão, os gêneros textuais se desdobram sem grandes rupturas, mantendo a continuidade da narrativa, diferentemente do que acompanhamos em Zero. Em Riverão, vários gêneros são inseridos no fluxo narrativo sem que este seja interrompido, salvo uma única e arrebatadora vez, conforme veremos adiante.

De modo geral, à semelhança de um rio que tudo leva por onde passa, a narrativa fluvial de Glauber carrega desde as elucubrações do narrador, passando por reflexões políticas e culturais dos personagens, às memórias e causos dos jagunços dessa comitiva, e aqui desembocamos na terceira experimentação narrativa: as relações transtextuais, partir da menção direta ou presença indireta de outros discursos, literários ou não, na obra. Riverão Sussuarana pode ser compreendido como "texto de segunda mão" ou "derivado de outro preexistente" (Genette, 2010, p.14) devido às relações transtextuais estabelecidas, a começar pelo título da obra.

O primeiro parágrafo, por exemplo, remete-nos a todo um ambiente cultural de época, evocando os jornalistas (Ybrahym Sued, Jacyntho de Thormes, JOSÉ OLYMPIO) e os veículos (Suplemento Letras do Dyaryo de Notycyas) que difundiam a cultura nacional no período; e aqueles que a produziam, notadamente, artistas do panteão moderno (Guimarães Rosa, José Lins do Rego, Graciliano Ramos, Carlos Drummond de Andrade, Joyce; Villa Lobos, Bach, Beethoven, Wagner, Strawinsky \& Portinary, Delacroix, Goya, Gaughin, Picasso), a quem Glauber reivindica filiação.

O diálogo transtextual é, portanto, estruturante da obra. Assim como PanAmérica parte dos mitos e referências da cultura de massas para criar seu Olimpo pós-moderno; Riverão Sussuarana dialoga com outros discursos, em particular, o épico de Rosa, por meio da hipertextualidade, definida por Gérard Genette, em Palimpsestos, como "toda relação que une um texto B (hipertexto) 
a um texto anterior A (hipotexto), do qual ele brota de uma forma que não é a do comentário" (2010, p.18).

\section{- Transformação e imitação}

Segundo Genette, duas operações são próprias desse tipo de relação: a transformação e a imitação. O primeiro caso seria, por exemplo, a tentativa de Joyce em transportar a Odisseia de Homero para a Dublin do século XX, trazendo em seu Ulisses, Leopoldo Bloom, um judeu e agente de viagens no papel de Odisseu; e transpondo a viagem de Troia à Ítaca em 19 horas de "viagem" pela capital irlandesa. Diferentemente da transformação, a imitação exige uma operação mais complexa: ela requer a "constituição prévia de um modelo de competência genérico" capaz de "gerar um número indefinido de performances miméticas", conforme detalha Genette:

\footnotetext{
Para transformar um texto, pode ser suficiente um gesto simples e mecânico (em último caso, extrair dele simplesmente algumas páginas: é uma transformação redutora); para imitá-lo, é preciso necessariamente adquirir sobre ele um domínio pelo menos parcial: o domínio daqueles traços que se escolheu imitar (...) Ou mais grosseiramente: Joyce conta a história de Ulisses de maneira diferente de Homero, Virgílio conta a história de Enéias à maneira de Homero (ibidem, p.19-20).
}

Por meio de procedimentos experimentais semelhantes aos utilizados por Rosa, Glauber fará seu elogio ao mestre, constituindo, aos moldes deste, um vocabulário próprio, a partir de novo léxico, palavras-valises e neologismos. Uma aproximação, aliás, que vem de longa data.

Em "Sertão e Narração: Guimarães Rosa, Glauber Rocha e seus desenredos", o professor Pedro Paulo Gomes Pereira (Unifesp) aponta Deus e o Diabo na terra do Sol como uma tentativa de reescritura cinematográfica de Grande Sertão (Pereira: 2008); destacando a originalidade de Glauber que 
incorpora as lições e o movimento de Guimarães no plano cinematográfico; a tentativa não é de adaptar para o cinema a obra de Guimarães, mas de dialogar com ela - reescrevê-la significa reinventá-la. Um dos primeiros aspectos que assinalam esse diálogo está na maneira de construir o sertão. (Pereira, 2008, p. 56)

O mesmo procedimento podemos observar em Riverão. Daí a constituição desse novo vocabulário prosódico por Glauber, entre outros aspectos.

Pereira, inclusive, destaca da linguagem de Grande Sertão: Veredas, a superposição e assimilação de vocábulos homófonos como "serepente: ser que de repente se transforma em serpente"; uso de substantivos na posição de verbos como "asmava"; de verbos na posição de adjetivos como "um voo de remorso"; ou a própria alteração da sintaxe criando novos sentidos como "É preciso de Deus exigir a gente, mais; e do diabo divertir a gente com a sua dele nenhuma existência" (ibidem, p.70).

Experimentações também buscadas por Glauber que irá construir uma musicalidade regida pelos aspectos lúdicos, em trechos como: "sacana é a cana da bandeiramericana quem tem dente chupa cana que não tem come banana sua boca de xibiu vá prá puta que o pariu" (Riverão, p. 21). Essa musicalidade também pode ser observada no excerto abaixo, que trabalha no plano de conteúdo com o signo Guimarães Rosa, em um exercício de profanação semelhante ao visto com os ícones do mass mídia em PanAmérica:

A menina levantou a saia preta e mostrou o rabinho rapado de creca cheirosa... seu Rosa lambeu... dedou...meteu... a menina gemexeu gostosa como manteiga nos ovos estrelados... minha filhinha gozou seu Rosa na sacanagem... e ela... ovos fritos na manteiga de meu amorzim... (Riverão, p. 17).

O interlúdio sexual acima é conduzido pelos aspectos prosódicos, por meio das rimas (lambeu, dedou, meteu, gemexeu / menina pulando, novilha peidando) e repetições (quero mais mais ai mais ai mansinho), acrescido dos léxicos corpóreo e alimentar, com lúdica pitada de estrelas nos ovos-colhões. $O$ 
que temos é o signo "Rosa", escritor e cânone literário profanado, enquanto personagem da obra, como um velho ("minha filhinha") em plena brincadeira sexual, acrescida da seguinte revelação:

Seu Rosa abotoando a braguilha perguntou ao Comandante quem era a mãe da menina: "Diadorim".

Seu Rosa Chorou: filha de Riobaldo com Diadorim?

(Riverão, p.18)

A brincadeira de outrora dá lugar à emoção do criador frente à própria criação, em discurso essencialmente metalinguístico, cuja possessão pelo afeto ("chorou") recupera os elos tímicos dessa "família" literária, por meio do hipertexto que se enuncia. Ao longo deste rio, margeado pela comitiva de Riverão, vai sendo edificado o ambiente dessa cosmogonia sertã, com a "encarnação" na obra dos dois autores (Rosa e Glauber) "compromissados com a verdade" e com a reflexão sobre o "miserabilismo", "antes escrito pela literatura de 30" e agora "fotografado pelo cinema de 60", "antes descrito como denúncia social e hoje discutido como problema político", conforme escrevia Glauber em sua Estética da Fome (Glauber, 2012, online).

Riverão parte, portanto, dessa mítica sertã, abraçada por Glauber e Rosa cujo

edifício da nova linguagem, colocação de problemática até então estranha para cientistas especializados, 'filosofia sertã' formam na obra rosiana tema indispensável à compreensão do Brasil (...) Ali o latifúndio e suas guerras de jagunços, mitologia vaqueira, duelo entre Demo e Deus, língua, amor, costume, jeito de SER. (Rocha, 2012, p.7)

É compreensível que, sob esta filosofia (filosofia sertã) e perspectiva (compreensão do Brasil), "Glauber Rosa" ou "Guimarães Rocha", assim fundidos em alguns momentos da obra, sejam apresentados enquanto unidade discursiva, afinal, como explica Pereira, 
a força crítica desses autores não se ancora prioritariamente na afirmação da identidade nacional por meio do sertão, mas na afirmação do sertão como diferença em relação às forças centrais ou hegemônicas da nação. O sertão de Guimarães e de Glauber, composto desse intricado de vozes, nesses desenredos, nesses intertextos, manifestando a preocupação com o diferido, justapõe, justamente por essa forma de composição, diversas temporalidades, culturas e territórios, que interagem e se reinventam. (Pereira. 2008, p. 77)

Recriado, portanto, a partir dessa hipertextualidade, Riverão Sussuarana irá reatualizar a cosmogonia sertaneja, como podemos observar no trecho abaixo que delimita a filiação da obra. A cena se passa após o interlúdio amoroso/metalinguístico de Rosa com a filha de Diadorim.

Disse pro Comandante que tinha estória de Payxão da menina por Riverão, aquele Rivo era primo de Riobaldo Tatarana dum tal Antonio das Mortes, dum falado Mata Vaca, d'Antonio Pernambucano, Passarim, do Matyta Perê, um certo João do Capitão Rodrigo, Lampião, Zé Bebelo, Joãzim Bem Bem, Hermogenes, Joca Ramiro e o Coronel Franklin Cavalcanti Martins pai do deputado e romancista Wilson Lins do Rio San Francysco atual Secretario de Educação do Governo Magalhães na Bahia.

Seu Rosa contou que conheceu Juracy na Parayba em 1930.

Que como legalista defendera Washington Luiz.

Que era reacionário.

O Comandante perguntou porque?

Seu Rosa: "A estória é contra a História."

Citou Heráclito.

(Riverão, p.18)

No excerto acima, Riverão é apresentado como "primo" dos principais personagens da literatura e realidade sertanejas, inclusive, políticos contemporâneos ao autor, também nordestino, ou seja, "diversas temporalidades, culturas e territórios" inseridas em um mesmo plano: personagens de Rosa (Zé Bebelo, Hermógenes, Joca Ramiro) ou outros 
escritores (Capitão Rodrigo), personagens de Glauber (Antônio das Mortes, Mata Vaca, Antônio Pernambucano); e personalidades da luta social (Lampião, Passarim) e política (Wilson Lins, Juracy Magalhães 36) na cosmogonia sertaneja.

Composto essencialmente de nomes próprios, todos "primos" do sujeito nomeado coloquialmente de "Rivo", em apelo familiar - o excerto termina com uma reflexão sobre estória e História, ou seja, o que se conta (estória) e o que acontece (História), em um mesmo patamar de correspondência das figuras e temas utilizados na construção desse sertão mítico, composto tanto por personagens fictícios (Antonio das Mortes, Riobaldo Tatarana) quanto reais (Guimarães Rosa). Ambos os regimes de construção da realidade (Floch, 1991) - o mítico e o referencial - relacionam-se pela mesma isotopia sertaneja, caracterizada pela luta secular, e disposta segundo a oposição semântica primordial opressão vs. liberdade do percurso gerativo do sentido.

De modo geral, em Riverão Sussuarana a oposição opressão vs. liberdade do nível fundamental é revestida, nos demais níveis, a partir dos valores patêmicos categorizados em disforia quando opressão, e euforia enquanto liberdade. É sob esse eixo que Glauber constrói seu sertão, revestindo as forças que figurativizam a violência do mais forte (político corrupto, explorador norte-americano, coronel assassino) contra o mais fraco (o povo, o brasileiro, o jagunço, o vaqueiro); e o revide, a vingança, a resistência do mais fraco contra o mais forte, sintetizada no conceito de "justiça pelas próprias mãos".

A oposição semântica é revestida pela história de Riverão Sussuarana, injustamente acusado de matar um parlamentar, e por isso perseguido pela polícia, como somos informados no excerto abaixo:

36 Governador da Bahia entre 1959 e 1963, Juracy Guimarães foi forte apoiador do golpe de 1964, e na condição de Ministro da Justiça (1965-1966), encarregado da censura aos veículos de comunicação em todo o país. Nomeado embaixador brasileiro nos Estados Unidos, ganharia fama pela frase "o que é bom para os Estados Unidos é bom para o Brasil" (Wikipedia https://pt.wikipedia.org/wiki/Juracy_Magalh\%C3\%A3es, último acesso em 24.03.2020). 
Riverão matou o deputado José Santana de Souza do PSD na Câmara Estadual da Bahya na cara do General Governador Juracy Magalhães, mandado pelo Coronel Deodorama de Taverna, um tal Ismael Mizerya corredor de pedras vermelhas contato do Sindykato da Morte de Maceyó com os matadores de Petrolyna. (Glauber)

A saga de Riverão tem início com a acusação acima, e num primeiro momento, o sujeito terá de lutar pela inocência contra as forças que o acusam. Sua sorte, no entanto, o levará ao contato com a massa faminta e explorada no interior do país, fazendo com ele que se torne uma espécie de novo Lampião, esperança do povo escravizado pelo norte-americano Karter Bracker. Riverão passará, portanto, da defesa da própria liberdade para a defesa da liberdade coletiva, contra interesses imperialistas no sertão brasileiro.

\subsubsection{A construção da substancialidade}

A experimentação promovida por essa estranha ortografia, que nos conduz à uma leitura minuciosa e à fruição dos efeitos de sentido da prosódia (aliteração, assonâncias, repetições), soma-se o labirinto referencial, capaz de esfumaçar os limites entre invenção e real. Ambas as inovações serão, porém, potencializadas pela subversão que Glauber opera nos modelos clássicos de enunciação do texto literário. Como vimos anteriormente, o processo de discursivização se dá pelo trabalho com as categorias dêiticas (pessoa, espaço e tempo) e actanciais (sujeito) do discurso, operando a projeção do sujeito no enunciado por meio de fenômenos próprios da enunciação: a debreagem (enunciativa ou enunciva) ou a embreagem, a partir da neutralização dessas categorias.

Em Teoria do Discurso: fundamentos semióticos, Diana Barros (Linguística - USP) traz um esquema da sintaxe discursiva, elencando os actantes da enunciação: enunciador e enunciatário, narrador e narratário, e interlocutor e interlocutário: 
Figura 17: Actantes da Enunciação

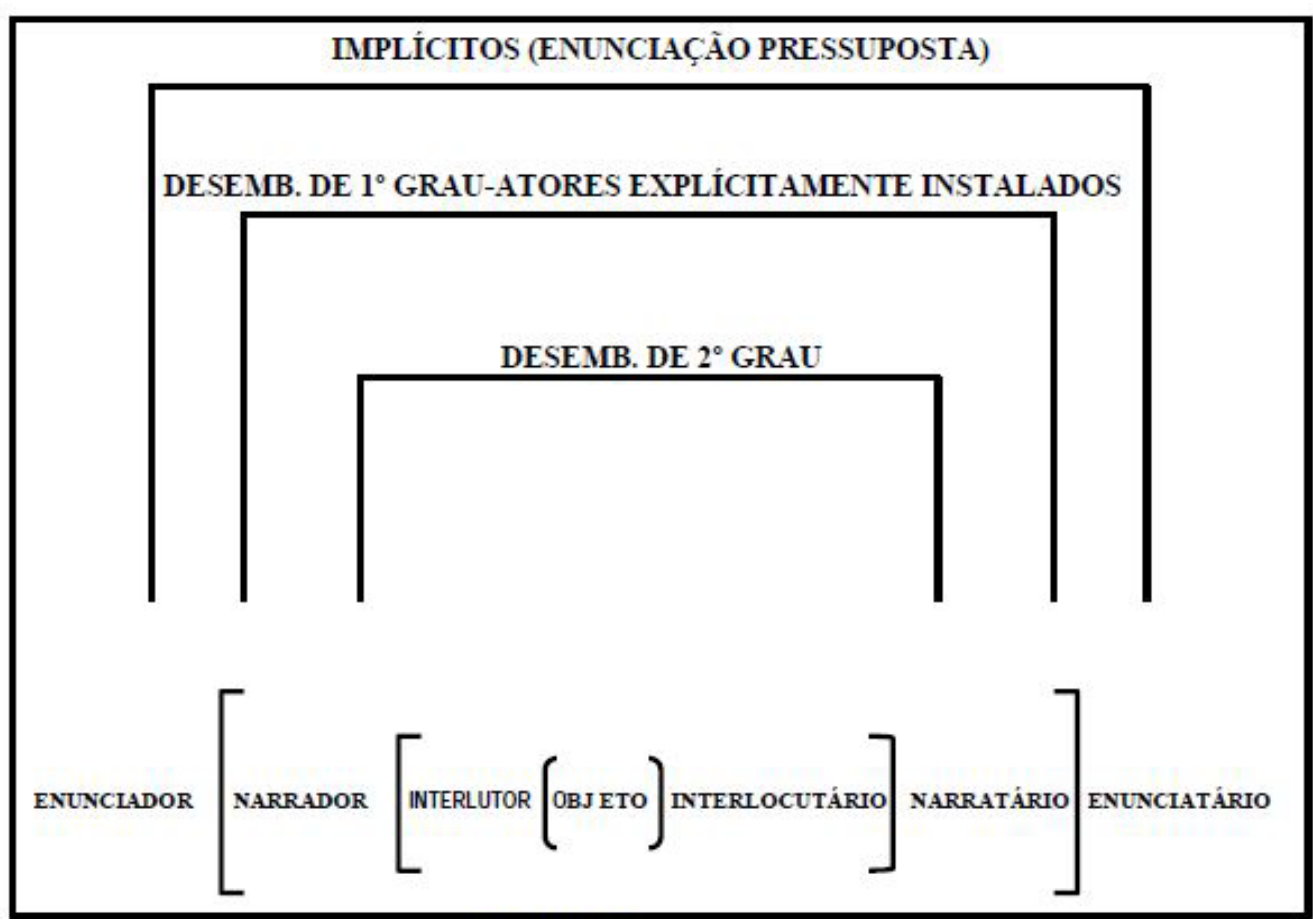

(Barros, 2002, p. 75)

$\mathrm{Na}$ debreagem de primeiro grau, esses actantes são instalados no enunciado sob a forma de narrador e narratário; e na debreagem de segundo grau (discurso direto ou indireto livre), sob a forma de interlocutor e interlocutário. $\mathrm{Na}$ embreagem, dá-se o movimento contrário, de neutralização das categorias de pessoa, tempo e espaço.

Num primeiro momento é possível identificar em Riverão, o uso da debreagem enunciativa que instaura a relação eu-tu, em uma narrativa contada em primeira pessoa por esse Glauber-repórter em um presente, o agora da caravana de jagunços; e no espaço do "aqui", no caso, o sertão onde os principais episódios da obra acontecem, como podemos ver no excerto abaixo:

Horizontes passavam e ficamos bebendo um Riacho calculando chegar às dez e dezoito quando a boiada beberia no Jequitinhonha: aí Riverão tomava banho, também o Comandante e se comeria feijão de tropeiro com banana, rapadura, mangas que tilintavam na lama. 
Seu Rosa me pediu para Ihe contar a vida de Riverão.

Não queria perguntar nada quando o encontrasse.

Vinha pra escrever reportagem pro "O Cruzeiro", do Embayxador Assyz Chatôbryand, e não faria propaganda na mensagem

Na estrada contei a vida de Riverão por assim, por Alá, parando para mijar, descemos a montanha por cascatespinhoza, acendi outro cigarro e no cavaquinho do pino manso os cavalos relaxaram (Riverão, p.14).

O excerto não admite dúvidas quanto ao narrador, indicado pelo pronome oblíquo ("me") e pela conjugação verbal ("ficamos", “acendi”). Trata-se de Glauber Rocha que terá em Guimarães Rosa, o principal destinador de suas ações. A enunciação ocorre no presente (em 1964) e no espaço da ação narrativa, no caso, a estrada percorrida pela comitiva (entre Minas Gerais e Bahia). Ao longo de toda obra, a debreagem enunciativa será o principal modo de enunciação, porém não será o único.

A debreagem enunciva, por exemplo, irá substituir a subjetividade impressa na relação "eu/tu" pela objetividade da enunciação em terceira pessoa, em outro tempo que não o presente (agora) dos acontecimentos, seja no passado ou no futuro. Esse modo de enunciação caracteriza um dos percursos temáticos da obra, que chamaremos de "histórias dos jagunços e dos vaqueiros". Trata-se de histórias sempre em flashback que trazem o ambiente e os temas que compõem a mítica sertaneja, verdadeiros causos do sertão, como a história de Anjo Mau, observado na cena abaixo pelo jagunço Mata Vaca:

Mata Vaca nunca tinha visto Angelo matar menino, confirmou idéia antiga, pensando que seu velho companheiro era sêco por dentro de arame farpado e galho de umbuzeiro.

Apagou a visagem viu sua caveira em cima do pescoço de ganso de Angelo e relembrou o varapau chorando lembrança e mêdo de se ver morto na morte de Anjo, dinheiro dentro das botas dava pra comprar pedaço de terra.

Comiam carne com feijão, bebiam aguardente: Anjo gostava de mandar um irmão ir com Deus. (Riverão, p.30, grifos nossos) 
Acima pode-se observar o efeito de debreagem enunciva na descrição do pensamento do jagunço Mata Vaca que, por meio da gradação, passa do espanto (morte da criança) ao medo (ser morto com ou por Ângelo), resultando em duas estratégias distintas: a do afastamento (dinheiro sob os pés) e a do convívio (desconfiado) com o amigo que assume, nesta e em outras partes, o papel de anjo da morte. Descrito por um observador parcial, o excerto constrói os pensamentos do jagunço - "confirmou", "pensando que", "relembrou" enunciado por um narrador que se identifica com Mata Vaca, a ponto de saber seus pensamentos e temores.

Comparados os dois excertos, é possível notar que a enunciação substitui a relação entre "eu-tu" anterior que caracteriza a enunciação do presente da caravana, relatado pelo repórter Glauber; por outra que estabelece um tempo outro (passado), um outro local (Afogados) e um narrador consumido pelo discurso indireto livre, como vemos na fusão do pensamento de Mata Vaca com a própria narração em "dinheiro dentro das botas dava pra comprar pedaço de terra".

Essas duas temporalidades - o presente da caravana e as memórias dos jagunços - são permeadas pelo discurso direto, resultante da debreagem em segundo grau do enunciador, que instaura a presença de um interlocutor e um interlocutário. $\mathrm{O}$ discurso direto será fartamente utilizado na obra, em particular, na construção de posicionamento políticos e consensos em geral fraternos. São bate-papos em meio à estrada ou ao estalar de fogueiras das noites densas do sertão brasileiro. Uma paisagem ora lírica, ora agreste, evocando relações de solidão e amizade, e reflexões sobre a situação da população desassistida.

Essas conversas abarcam de tudo - episódios históricos como a Coluna Prestes a queda de Jango; outras obras e das mais diversas linguagens, em particular, Cinema e Literatura -, como podemos observar abaixo na conversa entre Riverão e Luiz, o papagaio mágico da caravana: 
Riverão trotava curtindo estórias de Luiz:

-- Papagayo? Repetes palavras de outrem?

-- Ah aí seu Riverão tu eres jagunço famoso...

-- Fui também caubói e samurai

-- Tiveste na Anabazyz?

-- Na Ylyada na Odysséya nas Kruzadas e nas Deslobertas

-- Aventuras Expazyays?

-- Fui tema de Flash Gordon

-- Naquele carro de boi que traz a máquina de filmar tem baú cheio de guri/gibi/ edições maravilhosas ilustradas tudo pro garotim fica sabido...

-- Num tamo num faroeste seu Luiz... Tenho medo do Delegado Carango...

-- Monta nas minhas azas...

-- Quero levar Linda comigo... E num se trata só de amor... Tem a boiada e os vaqueiros... Sabe no que vai dar êsse itinerário?

-- Nêgo pro pelourim e boiada pro corte!

(Riverão, p.23)

No excerto acima é possível observar o imbricamento de referências míticas e históricas - Anábases (Xenofonte), Odisseia (Homero), Cruzadas e Descobrimento (história), aventuras espaciais e flash Gordon (cultura pop) -, em torno dessa "máquina de filmar" e demais objetos levados para o Cel. Dermeraveldo, financiador da caravana. A isotopia da arte e da imaginação é confrontada com as isotopias figurativas da escravidão e da constante ameaça de prisão (Delegado Carango) que sobrevoa a sina desse sujeito, emulando neste pequeno excerto a oposição liberdade (imaginação) vs. opressão (realidade).

Além da debreagem enunciva e debreagem enunciativa (que consistem na enunciação das categorias de pessoa, tempo e espaço), em vários momentos da narrativa, é possível observar o movimento inverso: de neutralização dessas categorias, no fenômeno de embreagem, 
A embreagem apresenta-se como uma operação de retorno de formas já desembreadas à enunciação e cria a ilusão de identificação com a instância da enunciação. A enunciação finge recuperar as formas que projetou fora de si. Nega-se o enunciado e procura-se produzir o efeito de suspensão da oposição entre os atores, o espaço e o tempo do enunciado e os da enunciação (...) Incluem-se como efeitos de realidade, de enunciação e de verdade também as ilusões contrárias: pode-se pretender obter efeitos de mentira ou de falsidade, de irrealidade ou de ficção, de distanciamento da enunciação (Barros, 2002, p. 77).

O excerto abaixo nos permite observar esse processo de neutralização. $A$ cena é a sequência do diálogo entre Mata Vaca e Anjo Mau:

\begin{abstract}
Mata Vaca acendeu dois candieiros que dava pra ver a roupa branca de Anjo atravessar o corredor de Sinhô Primo em cima da mesa compoteira doce de caju dentro do armário remexi numa lata de biscoitos, corto metade dum requeijão, trouxe moringa d'água, Mata Vaca grunhia mastigando, um menino chorou com sede, Anjo dei um gole no gargalo como se tivesse urinando, biscoito duro, doeu nos dentes, desistiu, mastiguei o macio do requeijão, engole sêco, água com gôsto de barro e Angelo só gosta d'água fresca e limpa, lembre-me do armazém, talvez encontrasse cerveja em cima do balcão iluminada pelo fifó que Anjo acende velhos jornais manta de toucinho coberta de mosca abano guia fifó encontro prateleira duas cervejas, pra Mata Vaca antes de sair arranhe com a unha pedaço de toucinho, prova metade de vez, Mata Vaca à medida que engolia a cerveja pernas de Anjo cortadas pela luz se movem cabeça degolada no escuro. (Riverão, p.31.)
\end{abstract}

Acompanhada de forte musicalidade, desde construções rítmicas ("mastiguei o macio do requeijão", "fifó"-"fifó") à acentuação e ortografia (sêco, gôsto) guiados pelos aspectos prosódicos do texto, a fluência da leitura será interrompida por uma inovação no plano do conteúdo. Se anteriormente nos excertos citados, inexistem dúvidas quanto à autoria da voz enunciativa, seja o narrador em primeira (Glauber-repórter) ou terceira pessoas (Mata Vaca), ou quanto à identidade do interlocutor (Riverão Sussuarana) do diálogo, agora, diante dos verbos conjugados em primeira pessoa - "remexi", "corto", "trouxe", 
"dei”, "mastiguei”, "lembre-me”, "encontro" - a pergunta se impõe: quem está contando essa história?

Uma primeira hipótese seria atribuir esses verbos ao próprio sujeito da ação narrativa, o jagunço Mata Vaca, concebendo-o como interlocutor no episódio, em diálogo consigo. Essa hipótese se sustentaria pelos dêiticos, Mata Vaca está no tempo e espaço narrados, é quem acende o candeeiro, observa os movimentos de Anjo Mau, remexe no armário, come o requeijão e bebe a água. Outra hipótese, seria conferir a voz narrativa ao próprio Riverão Sussuarana, na medida que a história de Anjo Mau dá sequência a diálogo entre ele e o Papagayo Luiz, e sabemos, páginas depois, que ele esteve em Afogados.

A dubiedade instaurada pela confluência de narradores evidencia a neutralização da terceira pessoa pela primeira, em processo de embreagem, potencializando, a partir da alternância da voz enunciativa, a dramaticidade da cena, inclusive, pela possibilidade de outro ator. Essa hipótese também ganha musculatura quando analisamos a semântica global da obra, que irá trabalhar e essa é sua subversão central - com diferentes narradores chamados "Glauber Rocha”, o primeiro assumindo-se personagem, que chamaremos de Glauberrepórter; e o segundo identificando-se como enunciador da obra, que chamaremos de Glauber-autor.

\section{- Presenças de Glauber}

Em sua definição de regime substancial no discurso publicitário, Floch menciona propagandas que exaltam os atributos físicos de seus produtos, destacando a incidência desse modo de construção do real que passa pela construção de uma presença física. Afirma-se a presença física do objeto. Pietroforte, por sua vez, ao investigar o discurso pictográfico, aponta como substanciais as pinturas que utilizam vestígios corporais (sangue, urina, esperma), explicitando o hibridismo entre corpo do autor / corpo da obra. Conceber, portanto, o regime substancial em termos de linguagem verbal, diz respeito à apreensão da construção dessa fisicalidade. Constitutiva da fusão 
entre obra e criador, a presença dessa fisicalidade em Riverão Sussuarana se dá de diferentes formas.

Concebida em momento chave da escritura do cineasta, a passagem da Estética da Fome para a Estética do Sonho, quando ele pauta a mítica revolucionária, Riverão Sussuarana irá construir essa presença física, inicialmente, desenvolvendo a musculatura de uma ortografia que, como vimos, promove a alteração do código linguístico, instaurando a predominância dos aspectos prosódicos (a oralidade) sobre os ortográficos (a escrita). Essa marca escritural que permeia a obra do começo ao fim constitui uma primeira camada de substancialidade, na medida em que essa ortografia será utilizada por Glauber enquanto marca escritural em outros textos.

A fisicalidade também é construída a partir do diálogo com Rosa, em franco processo de imitação (filiação) dos experimentalismos trilhados pelo escritor mineiro. Riverão é, neste sentido, o hipertexto de Grande Sertão: Veredas, obra essencialmente mítica. Um diálogo e autorreflexão do artista que, pelos caminhos de Rosa (e com o próprio autor do lado), experimenta pela primeira vez a linguagem verbal de modo poético. E neste processo Glauber se autorreferencia, citando vários personagens de sua própria filmografia. Soma-se a isso, a série de pistas biográficas espalhadas pelo texto.

Conforme destaca Raisa Damascena Rafael, em dissertação intitulada Riverão Sussuarana - uma re-visão (2012), defendida no programa de Memória Social da Universidade Federal do Estado do Rio de Janeiro (UNIRIO), entre outros fragmentos da biografia familiar do autor, está a história do pai de Glauber, Adamastor Bráulio da Silva Rocha, diluída no episódio referente ao "Seu Dama", relatada em primeira pessoa e iniciada da seguinte forma:

- OI, nasci em 13 de Fevereiro de 1908, em lugar por nome Bom Jesus, no município de Jequiriça na Bahia. Aí fiquei até, bota aí 6 anos, mais ou menos. Eu, minha mãe e meus irmãos ficamos ai nessa fazendinha e meu pai veio para o município de llhéus dedicar-se a outros trabalhos para ver se conseguia melhorar sua renda e consequentemente a melhora do bemestar da sua família. De vez em quando ele ia lá em Bom Jesus visitar-nos. E depois voltava. Passa de uns 4 anos de sua estadia na zona de llhéus, ele conseguiu comprar uma fazendinha e foi nos buscar. Viemos. Eu e toda a família (ROCHA, 2012, p. 40-43). 
Esse conteúdo memorialístico é mesclado à própria trama, assim como outros episódios de rememoração, por exemplo, o bilhete de Guimarães que vemos no início da obra (e deste capítulo), entre outros excertos mesclados à história dos jagunços. Além da ortografia personalizada e das pistas biográficas, inseridas na trama, a presença substancial do autor, enunciador e personagem da obra é trabalhada em termos discursivos sob a égide de um verdadeiro delírio enunciativo. O signo "Glauber Rocha" nomeia dois narradores diferentes, inscritos em programas narrativos distintos e, também, construídos em dois regimes de construção da realidade distintos:

(1) Programa narrativo que aponta para o regime mítico, onde ficção e realidade se diluem à serviço da cosmogonia sertã, e aqui os discursos mítico e oblíquo se alternam. De fogueira em fogueira, compartilhamos os causos de jagunços, as conversas políticas, as reflexões sobre obras e a produção cultural do período, juntamente com as divagações desse narrador "amigo de Guimarães Rosa". Neste percurso, o narrador se identifica como personagem da obra, e a sua realidade irã dialogar com o universo temático e figurativo desse sertão em continua construção.

(2) Programa narrativo que aponta para o regime referencial, trazendo uma realidade outra que engloba a primeira, e assim instaurando a substancialidade, passando-se no cenário e com os personagens que dizem respeito ao tempo e espaço de escritura da obra. Não se trata mais do sertão, mas do Rio de Janeiro urbano, e de personagens que fazem parte da realidade do autor Glauber Rocha. Neste novo programa narrativo, os índices de referencialidade englobam a mítica ficcional, reivindicando o luto, a morte e a dor desse autor que se diz Glauber Rocha, autor de Riverão Sussuarana, promovendo o efeito de sentido de "rasgo", ou melhor, de revelação sobre o real, a ponto de implodir o primeiro programa narrativo que se passava no ambiente e em meio às isotopias do universo sertanejo.

Em Riverão Sussuarana, a presença performática de Glauber se faz sentir, portanto, por meio de diferentes narradores que se manifestam em fluxo 
de pensamentos. Esses dois percursos serão construídos a partir da enunciação enunciada, do enunciado enunciado e da enunciação reportada. E preenchidos por três vozes narrativas que, somente para fins de análise, nós chamaremos de Glauber-repórter, Glauber-implícito e Glauber-autor, conforme a apresentação desse narrador como ator da obra, em enunciação enunciada; como enunciador implícito, em enunciado enunciado; e como autor da obra, em enunciação reportada. Vejamos cada uma delas.

\section{- Glauber-repórter}

Enunciado em debreagem enunciativa, Glauber-repórter relata em primeira pessoa, com focalização parcial, o andamento da caravana de jagunços, participando como ajudante de Rosa na reportagem sobre Riverão Sussuarana, encomendada por O Cruzeiro. É, portanto, uma voz narrativa identificada como um ator da obra. Revestido com as características do cineasta Glauber Rocha, ele irá enunciar o "aqui e agora" da caravana, e terá em Riverão, seu objeto de valor, na medida que em torno do jagunço gira a reportagem e a própria obra. Glauber-repórter irá se relacionar com várias personalidades da mitologia sertaneja, reais ou ficcionais, e terá em Guimarães Rosa, o destinador de suas ações.

A relação de confiança (contrato fiduciário) que permitirá ao destinador manipular o fazer do destinatário é construída desde a primeira página do livro, com a inserção de artigo de Glauber sobre a importância da literatura roseana no exterior, e considerações sobre o exercício da tradução de Rosa.

De certo modo, é possível compreender Riverão Sussuarana como uma "tradução" dos procedimentos experimentais adotados no clássico rosiano, na medida em que o cenário, os personagens e até mesmo o autor da obra são transplantados para Riverão. Ao mesmo tempo, a presença de Rosa pode ser lida como reivindicação, em termos de filiação literária, à escola dos que professam (Rosa, Euclides) a filosofia sertã. 
Esse artigo/prefácio é sucedido de uma dedicatória de Rosa a Glauber, datada de 1962, e impressa no romance, em nova fusão dos elementos ficcionais e reais no texto, que torna crível o contrato de fidúcia (confiança), responsável pelo fazer-fazer do sujeito Glauber-repórter. Sem Rosa, aliás, não existe a inserção de Glauber na narrativa e, muito menos, narrativa. Em Riverão Sussuarana, tudo começa e termina em Guimarães Rosa, o principal destinador das ações de Glauber-repórter.

No excerto abaixo, inclusive, "mestre Guima" manipula o Comandante para que ele aceite o cineasta na caravana, como vemos no excerto abaixo:

Apresentou-me ao Comandante: "Este é o Acadêmiko de Direito Baiano Glauber Andrade Rocha que é também crítico literário, cinematrográfico, diretor teatral, contista, repórter policial e cronista mundano na imprensa baiana e carioca. Meu amigo. Pessoa de confiança. Quer conhecer Riverão (Riverão, p. 17, grifos nossos).

Em negrito estão elencados os atributos do destinatário Glauber Rocha bacharel em Direito, crítico literário, cinematográfico, diretor teatral, contista, repórter policial, cronista mundano na imprensa baiana e carioca - ou seja, todos extraídos da vida real, evidenciando o saber-fazer e o poder-fazer de Glauber que, enquanto ator narrativo é, também, "amigo", "pessoa de confiança" de Rosa. Glauber-repórter é duplamente competente enquanto sujeito de ação (atributos da referencialidade) e, também, enquanto sujeito de estado (atributos da personagem Glauber-Rosa) para executar a performance que é, em última instância, escrever Riverão Sussuarana.

Além de principal destinador das ações de Glauber, Rosa também manipula o poder-fazer do Comandante, tentando-o a partir da oferta dos serviços de Rocha enquanto sujeito da ação; e de seus atributos (ser de confiança) enquanto sujeito de estado. Ao longo do livro, inclusive, surgirá uma terceira competência deste narrador: o seu conhecimento sobre Riverão, que chegou a ser funcionário de seu avô: "era criado do meu avôzim... um sarará... E quando nasceu não sabe” (Riverão, p.14). 
Temos, portanto, um narrador que apresenta todas as suas credenciais para narrar a obra: os atributos todos do cineasta e repórter Glauber Rocha, o que não é pouca coisa; a filiação artística a Guimarães Rosa, construída inclusive no plano de expressão da obra; e o fato dele ser neto do ex-patrão de Riverão, portanto, próximo à história do jagunço.

Uma segunda manipulação é necessária para acontecer a trama. $O$ Comandante, destinador das ações de Riverão Sussuarana, deverá convencer o jagunço, em uma das primeiras aparições do sujeito na obra, a realizar a reportagem, utilizando-se da manipulação por tentação, como podemos observar no excerto abaixo:

O Comandante tirou do bolso da camisa vidro com pílulas vermelhas e deu pra Riverão tomar quatro por dia. "E passe bem. Tem um jornalista do Rio com um rapaz da Bahia pra fazer reportagem. Gente boa. Pode servir pra Ihe defender".

- "Mas num tiro retrato".

(Riverão, p.33, grifos nossos)

Em sua função de destinador, o Comandante convence o sujeito, Riverão Sussuarana, a aceitar a presença de Rosa e Rocha, apresentados como sujeitos de estado ("gente boa") e de ação, afinal, ambos podem "servir" para defender Riverão, ajudando-o a conquistar a liberdade.

O excerto, apesar de pequeno, permite-nos observar: (1) a construção da relação de amizade (fidúcia) entre ambos, o Comandante leva remédio ao jagunço, atuando como destinador das ações do jagunço; (2) a manipulação por tentação, com notória euforização da arte e da imprensa enquanto veículos de proteção da pessoa e da verdade ${ }^{37}$; (3) a construção da personagem em apenas uma fala - "Mas, num tiro retrato" -, na caracterização dos valores e hábitos desse jagunço que negocia, com pouquíssimas palavras, impondo seus limites: ninguém pode ver a sua imagem.

37 A ausência de legitimidade da mídia, própria de governos autoritários, soma-se hoje à ausência de ferramentas capazes de nos proteger da incidência de desinformação e teorias da conspiração, propositalmente inseridas no ambiente digital, tal como um vírus, como é possível apreender em documentários como O Dilema das Redes (Netflix, 2020). 
Ocorre, portanto, a junção de universos contrários: o da exposição (Glauber-repórter) e o do silenciamento (Riverão Sussuarana), do global e do local, do moderno e do arcaico, com plena afirmação da independência desse sujeito: há coisas que Riverão não faz, tirar retrato é uma delas. Ele mantém sua independência (poder-não-fazer) e ainda afirma a liberdade (poder-fazer) - aliás, a sua e a daqueles que liberta da escravidão impingida pelo antissujeito Karter Bracker.

Em Riverão, Glauber-repórter, enquanto ator da obra, também realizará a performance que é a entrega da reportagem ao Cruzeiro:

- Acho que isto envolve questões de Segurança Nacyonal deixei Olyveyra Bastos Redator Chefe do "Correyo Brazylyense" que no dia seguinte compareceu à comissão Parlamentar de Inquérito para revelar detalhes sobre a penetração multinacyonal nos ynteryores brazyleyros em busca de plutonyo politicagem com Ygrejas índios posseiros grileiros e pediu liberdade de imprensa extinção censura na tempestade da semana santalvorada Rosa

Mytoz nacyonais.

(Riverão, p.231)

Uma performance sancionada positivamente a ponto de o texto servir enquanto instrumento de investigação sobre o "imperialismo ianque" no país. A entrega do livro a Oliveira Bastos (redator-chefe de O Cruzeiro entre 1976 e 1982) é acompanhada de fina ironia: "acho que isso envolve questões de Segurança Nacional", aponta Glauber-repórter, denunciando a festa das multinacionais no país. Após a entrega da obra, a voz de Glauber-repórter se liquefaz na voz do autor identificado com o autor da obra, carregado pelo fluxo de consciência. Antes dele, porém, vejamos um terceiro narrador, aqui nomeado de Glauber-implícito devido à presença mínima de marcas enunciativas no texto. 


\section{- Glauber-implícito}

Intermediário entre Glauber-repórter e Glauber-autor, ambos identificados com actantes narrativos, Glauber-implícito interfere o menos possível na narrativa, aos moldes do enunciado enunciado, ou seja, apagando as marcas enunciativas. Identificando-se como enunciador da obra, Glauber-implícito, apesar de não figurativizado, permanece atrás das câmeras, seja alternando o programa narrativo com Glauber-repórter e outros narradores do percurso dos jagunços; seja alternando com Glauber-autor no programa substancial, que detalharemos adiante.

Dotado de uma focalização total, a este narrador em terceira pessoa, caberá narrar os acontecimentos do programa narrativo do regime mítico e substancial. De modo geral, sua presença instaura uma perspectiva mais panorâmica da trama, em focalização total. Vejamos abaixo, ao longo da apresentação do programa narrativo da obra, que tem como principal sujeito o jagunço Riverão Sussuarana, como esse narrador se manifesta:

Riveirão matou o deputado José Santana de Souza do PSD na Câmara Estadual da Bahya na cara do General Governador Juracy Magalhães, mandado pelo Coronel Deodorama de Taverna, um tal Ismael Mizerya corredor de pedras vermelhas contato do Sindykato da Morte de Maceyó com os matadores de Petrolyna. (Riverão, p.14)

Os mandantes, envolvidos e prováveis assassinos do parlamentar José Santana de Souza do Partido Social Democrático (PSD) são elencados conforme graus da institucionalidade: o governador, o coronel, o jagunço, aos quais se une $\mathrm{o}$ antissujeito delegado Carango, trazendo 0 mote dessa institucionalidade corrupta e corruptora.

Junto com Karter Bracker, eles constituem as forças antagonistas da trajetória desse sujeito, ameaçando sua liberdade, conforme o programa abaixo: 
Destinador

Comandante

Cel. Dermeraveldo

\section{Sujeito}

Riverão Sussuarana
Objeto de Valor

Liberdade Individual

\section{Antissujeito}

Delegado Carango (candidato pelo MDB) / Cel. Deodorama / Juracy Magalhães (Corrupção política)

Essa busca pela individual, porém, terá um revés: o golpe de 1964. Em dado momento, o Comandante manda Riverão se assentar em novas terras, o que Ihe garantiria senão a justiça, pelo menos uma temporária liberdade individual. Entretanto, o plano é alterado pelo fechamento das estradas em todo o país, impedindo a conjunção entre sujeito e objeto de valor, conforme descrito no excerto abaixo:

Enquanto Luiz contava pra Riverão os últimos acontecimentos políticos o jagunço viu o limite da Terra e se levantou na sela pra buscar mais horizonte ao conforto do sorriso:

- Que amargura... Nascemos por aqui e doramos mundo até morrer... Teve uma Revolução do lado de lá e nós aqui sem poder chegar na Terra Prometida... $O$ Comandante vai ficar triste, a não ser que seja amigo de algum General... Coitado... se quiser enriquecer vai ter de roubar o gado do Coronel Dermeraveldo...

Ao entreposto de Lagoa Baixa, encruzilhada de Saco da Onça Tem Gado Bravo com Nova Canãa, não sabendo o que fazer diante da Revolução que cortava o fluxo das Entradas de Bandeyras, aldeiola de caibros e barro, chegou em Maio de 1964 a caravana de Riverão, engrandecida pela trupe de ciganos e flagelados devoraram vacas e touros, alguns vaqueiros comidos vivos, explosão famélica, imoral degradação na ruela habitada por trezentos garimpeiros às margens do Lago Kamela Narô em cujo fundo ninhos de Peixe Cobra pariam pedras preciosas e a maioria da população desbraçada despernada por jacarés que protegiam. (Riverão, p.96, grifos nossos) 
No excerto acima, momento de reviravolta na trama, o percurso do sujeito é interrompido: no "limite da Terra", Riverão e o papagaio Luiz percebem que jamais poderão se instalar em Nova Canaã (Bahia), daí a dupla referência à Terra Prometida, devido à "Revolução do lado de lá", leia-se o golpe de 1964, evocado como condição de parada não apenas do sujeito, mas obstáculo generalizado ao fluxo das estradas do país. O episódio político atinge o sujeito duplamente, porque atrapalha o percurso do seu principal destinador, o Comandante, que progressista, ex-membro da Coluna Prestes, passará agora a depender do compadrio (amizade com algum militar) ou do roubo de gado - $\mathrm{e}$ temos aqui uma referência direta ao mote de Deus e o Diabo na Terra do Sol "se quiser enriquecer".

É quando surge a trupe de famélicos que, em meio ao desespero generalizado, atuará como novo destinador das ações de Riverão, transformando-o em herói popular e libertador dos povos escravizados por Karter Bracker, o segundo antissujeito da obra, que mantêm negócios com o primeiro, o Delegado Carango que deseja prender Riverão para ocultar o verdadeiro assassino do parlamentar. Esse novo antissujeito reunirá todas as características do vilão: é norte-americano e imperialista assumido, comprador a preços facilitados de terras brasileiras, explorador de urânio e de trabalho escravo, em suma, o mal personificado.

O percurso anterior agora se complexifica em:

\section{Destinador}

Sujeito

Povo miserável/ Consciência
Objeto de Valor

Liberdade Coletiva

\section{Antissujeito}

Delegado Carango / Karter Bracker

As competências do sujeito também serão construídas ao longo da narrativa, criando condições para sua vitória contra o imperialista. Dois breves 
excertos revelam seus atributos, conforme duas estéticas elencadas por Glauber: a da fome e a do sonho.

Vejamos o primeiro caso:

O pai de Riverão roubou o cavalo Joaquim dum cigano. Deu em fogo. Mataram o cigano e o pai de Riverão perdeu os ovos. Foi decapitado. Riverão criou-se pelo tio Ernesto Galvão que Ihe cortou o dedo mindim. Lhe fez jurar vingança. Crescido Riverão foi discípulo de Peralva, um pistoleiro gaúcho. Entrou na Pensão Pedroza e matou os assassinos do pai. Preso, tocou fogo na cadeia e fugiu pra Bahya. (Riverão, p.15).

Como bom herói trágico, a luta de Riverão Sussuarana e suas competências dizem respeito à tradição de justiçamento do cenário sertanejo, fundante do seu destino. Desde pequeno, e em seu próprio corpo - dedo amputado -, Riverão está marcado pela vingança e pelo fazer justiça, em um cenário sem Estado, onde a lei do mais forte vigora: do pai sobre o cigano, dos assassinos sobre o cigano e sobre o pai; do tio sobre o menino; do homem sobre os assassinos do pai. Essa cadeia de violência, entoada pela Estética da Fome, atua em um contínuo, num ciclo de deveres que captura o menino, fadado ao eterno dever-fazer (matar, vingar, justiçar).

Seu destino é regido pelos valores de ascendência paterna que correspondem à luta pela sobrevivência, afinal, o cavalo roubado é um instrumento de trabalho, revelando o ambiente de injustiça generalizada, calcado na exploração do corpo do mais fraco pelo mais forte. Além da sina trazida pelo pai, a competência guerreira de Riverão se deve à herança materna, que lhe dota de competência crucial para enfrentar o destino trágico, povoado de vinganças: o corpo fechado, por meio de poderes sobrenaturais, oriundos da Estética do Sonho, da força que vem do transe, da possessão mágica, da mítica que move as massas populares, magistralmente sintetizada no excerto abaixo: 
Que o corpo de Riverão era fechado.

A mãe o benzera com Santos Poderes e lhe disse vai Filho Meu Pelas Chagas da Cruz e de mais Trinta Cruzes enquanto não cavarem tantas quantas trinta e uma causadora em Kryzto e mais Trinta Santos que são cento e vinte quatro bala nenhuma pega apanha fura bate raspa voa longe entorta pinta de faca facão sobre punhal canivete tezoura gilete caco de qualquer mineral e desvenena toxicos totais $\mathrm{d}$ abio fisisa a da anti materia expulsa os caracanaosos dos sorosrofobos vus sizis svavaia aoslshos sfetido e bala nenhuma apanha nenhuma bala nenhuma te apanha nem no tronco ou cabeça menos pés ou mãos e não Ihe arranharia as roupas e ele abraçou a velha nas rezas que foram se perdendo pra tras das arvores ao passo que o castanho abria campo eternamente longe da mãe nunca mais vista ou sabida. (Riverão, p.114, grifos nossos)

Agora, a linguagem se bifurca emulando em seu plano de expressão o efeito do que se enuncia no plano de conteúdo: o momento em que a palavra se torna ato, performatizada enquanto reza, por meio dos aspectos prosódicos na construção desse canto balbuciado, como demonstram os elementos marcados em negrito. $\mathrm{Na}$ construção dessa palavra-ato na linguagem verbal, a palavra mágica se revela canto e reza popular, por meio de rimas, aliterações e assonâncias, e a iteração de termos como "bala nenhuma apanha nenhuma bala te apanha nem no tronco ou cabeça...".

Essa camada performática confere substancialidade à narrativa, a partir da correlação do plano de conteúdo e de expressão na construção da palavraato, capaz de evocar os santos protetores - Krysto, Trinta Santos -. Uma proteção para cada possível tragédia enunciada. Ao dizer "punhal canivete tezoura...", essa mãe instaura um não-poder-fazer "punhal canivete tesoura". E sua reza embala o corpo do herói, até que se revela reza-despedida, culminando no abraço derradeiro dessa mãe, após fechado o corpo e abençoado esse filho, que irá pela estrada sem volta da vida, "eternamente longe".

Esse é o Riverão construído por Glauber-implícito, não mais com focalização parcial (Glauber-repórter), mas com o distanciamento necessário à focalização total da cena. Em terceira pessoa, ele nos permite reconhecer as competências do sujeito que, à mercê da própria sorte (como o país), terá de provar sua inocência e enfrentar aqueles que o acusam da morte do parlamentar. 
A saga desse sujeito será a permanente luta contra a opressão. E se num primeiro momento, a conquista da liberdade diz respeito à afirmação da inocência, em busca de paz e liberdade; a partir do fechamento das estradas (excertos acima), isso se altera. Riverão se tornará defensor dos famélicos e ganhará fama, agora temido pelas autoridades, enquanto novo Lampião (novo "lamp", conforme a linguagem pop). E aí uma série de estratégias serão mobilizadas contra o sujeito, como podemos observar no excerto abaixo que revela o abismo entre o discurso oficial e o discurso dos fatos, lembrando-nos que fake news, as chamadas notícias falsas, antecedem o ano eleitoral de 2018:

Lima Ferraz temia o perigo dum novo Lamp na figura de Riverão, falava-se que tinha sequestrado o Embaixador Romancista João Guimarães Rosa e o Cine Reporter Glauber Andrade Rocha, após matar Lalantino Desiderio Anjo Mau, o Comandante Elizor da Costa Fernandes Silva e prometer levar a cabeça de Karter Bracker pra Brazylya, tinha ordens do Governo Federal de prender Riverão, mais vivo do que morto, mas êle, Carango, queria atirar no primeiro movimento de sombra. (Riverão: 218, grifos nossos)

O excerto acima é um exemplo de discurso encrático (Barthes), realizado por Calango e os envolvidos na morte do parlamentar do PSD, que querem incriminar Riverão, dizendo que ele havia sequestrado Rosa e Glauber, depois de ter matado Anjo Mau, o Comandante e ameaçar de morte Karter Bracker. Como viemos acompanhando o que, na realidade, aconteceu em cada um dos episódios acima mencionados, temos também a construção de um índice de "referencialidade" interno à obra, afinal, o enunciador que Riverão jamais sequestrou Glauber e Rosa que, por sua vez, aguardam a entrevista com o jagunço. O discurso é uma desinformação, comum em momentos de guerra e desestabilização dos poderes, criada pelo delegado Carango que não pode se envolver em crime algum, afinal é ele "que agora se diz candidato pelo MDB", alfineta Glauber Rocha, inserindo o antissujeito da obra naquele partido.

O percurso da caravana, que ocorre no interior do regime mítico, reúne vários modos de enunciação que se alternam, sem mudanças bruscas como vemos acontecer em Zero. Em Riverão, uma longa história de jagunço, iniciada no começo do livro, pode ser interrompida pelos acontecimentos da caravana, 
ser posteriormente retomada e novamente interrompida, finalizada ou abandonada. O central é que esses variados percursos narrativos compõem o universo mítico da obra: conforme corre, o afluente mítico se embrenha por vários modos de enunciação e gêneros textuais, desdobrando seus percursos narrativos em outros, sem a preocupação com a lógica linear que caracterizam enredos com começo, meio e fim, afinal, trata-se de narrativa orientada pela estética do sonho, pelo irracional, pela espontaneidade, pelo acaso.

Inexistem pontos finais nessa história. Uma figura desemboca em outra percorrendo os caminhos abertos pela hipertextualidade, inclusive, personagens e cenário próprios da cinematografia de Glauber são recuperados, como vemos nos embates pela reforma agrária em Jardim das Piranhas, território de $\mathrm{O}$ Dragão da Maldade contra o Santo Guerreiro. Nesse jogo polifônico, enredos e competências pregressas, adquiridas em programas narrativos anteriores, conferem novo sentido à narrativa $E$ são vários os temas e figuras que confluem na edificação desse "Texto" (aos moldes barthesianos) do "sertão", palco da guerra travada entre os poucos que muito possuem e a imensa maioria dos que nada têm.

Além de Glauber-repórter, que nos traz a enunciação subjetiva e parcial de um narrador identificado com esse personagem inscrito no tempo mítico da caravana; e de Glauber-implícito, que nos traz a enunciação objetiva, sem marcas enunciativas, com focalização total; nós temos um terceiro narrador que chamaremos aqui de Glauber-autor.

\section{- Glauber-autor}

Entre as mais diferentes experimentações da narrativa, como vimos no excerto acima relativo a Anjo Mau, nenhuma se compara à descontinuidade narrativa promovida pelo excerto abaixo: 
A morte de minha irmã Anecy Rocha, no Marçabril carioca de 1977, arrebentou a estrutura de "Riverão Sussuarana". Ela estava aqui na copa numa tardomingueira e naquele dia de manhã a encontrei na Rua Voluntarios da Patria, Botafogo, com o filho dotivo vindo do apartamento do marido para tomar café na casa de minha mãe, Rua das Palmeiras, nos cumprimentamos afetuosos sem beijos e abraços, olhei as revistas e jornais na Banca e ela me disse para não tomar 0 Elevador da Frente, que estava quebrado, e sim o dos fundos, em caso de subir para falar com o marido que dormia.

Almoçamos juntos e eu disse a Necy, diante de minha mãe e do marido, depois de ouvir suas queixas:

- Mude de vida senão você morre - e ela sorriu secretamente fascinada.

(Riverão: 177, grifos nossos)

Quem narra o excerto acima? O que está sendo narrado? Onde? Quando? Seguramente não é mais Glauber-repórter, tampouco Glauberimplícito. Trata-se de um terceiro narrador que, em embreagem enunciativa, inscreve um "eu, aqui e agora", neutralizando as categorias de pessoa, tempo e espaço dos narradores anteriores (Glauber-repórter e Glauber-implícito).

Reivindicando seu papel de "autor" da obra - apontando para o enunciador - Glauber-autor instaura o regime substancial, a partir do imbricamento de dois regimes de construção da realidade, ou dois afluentes neste Riverão - o regime mítico, em torno da caravana de jagunços, narrado por Glauber-repórter, na condição de ator deste programa narrativo; e o regime referencial, consequência da introdução desse novo programa narrativo, referendado na vida pessoal do autor.

Esse segundo percurso, ao ser introduzido na obra, irá negar o regime mítico (narrador Glauber-repórter) e afirmar o regime referencial (narrador Glauber-autor), fazendo com que o segundo englobe o primeiro; e promovendo, assim, o efeito de sentido de "revelação" capaz de promover a descontinuidade ao substituir a realidade dos jagunços por outra realidade, muito mais próxima do leitor, agora diante de um narrador que irá predominar sobre os demais.

Glauber-autor será enunciado a partir de distintos gêneros (diário íntimo, comentário crítico, poema, teatro, conto), em uma montagem menos 
descontínua (em termos de fragmentação formal) que observamos em Zero ou PanAmérica. Em Riverão, é possível notar tanto o cinema de montagem, construído pela justaposição de discursos sob as restrições de diferentes gêneros discursivos; quanto a fluidez do plano sequência, em particular, nos trechos que constroem os feitos heroicos da épica sertaneja. Nada, porém, equivale ao impacto do excerto acima, quando a descontinuidade se manifesta de modo brusco e total, introduzindo a enunciação reportada que informa ao enunciatário que Riverão Sussuarana é uma ficção, seu narrador não está no lombo de um cavalo ao lado de Guimarães Rosa, mas sim no Rio de Janeiro, emocionalmente dilacerado pelo luto da irmã. Ou seja, além de expresso na narrativa, também é enunciada na obra o contexto que a engloba, e que diz respeito à profunda tristeza desse autor, que assume outro programa narrativo: o do irmão enlutado.

O primeiro efeito dessa ruptura é a construção do sentimento de proximidade entre enunciador e enunciatário. Em relação aos demais narradores da obra, Glauber-autor dá um passo adiante, trazendo o ambiente - o contexto - da escritura do texto. Essa presença é construída, também, pela predominância prosódica no plano de expressão, do diário íntimo sobre o romance literário, e da intensificação do fluxo de consciência que parece tudo arrastar enquanto passa, afirmando-se espontaneidade, "desrazão", entorpecimento rítmico e vertiginoso jorrar de referências.

O segundo efeito é o da interrupção do encadeamento mítico. Até então, Riverão Sussuarana, construía sua realidade a partir de temas e figuras articuladas pelo universo da mítica sertaneja. Em meio a ele, era possível localizar referências, aqui e ali, sobre a vida pessoal e familiar de Glauber, dissolvidas nas histórias de jagunços. Nenhuma dessas memórias ou interferências, porém, foram capazes de impedir o andamento da trama, instaurando novo sujeito, nova espacialidade e nova temporalidade no discurso que passa a ser dito por narrador ("eu") não menos personagem da obra, mas que reivindica o status de autor, apontando, em termos narrativos, para o papel actancial do destinador transcendente; em uma temporalidade que não é mais 1964, mas o contexto de produção da obra, entre 1977 e 1978; e em um 
ambiente muito distinto do sertão: o Rio de Janeiro, urbano, com outros atores e familiares, retrabalhados por Glauber sob o peso da tragédia pessoal.

Ao interromper o regime mítico de construção do real, próprio da caravana dos jagunços e da vida sertaneja, somos lançados à uma realidade que se constrói enquanto contemporânea à composição da obra. Afirma-se o regime referencial e nega-se o mítico, o narrador, inclusive, reivindica a autoria do percurso mítico e o faz com informações privilegiadas, por exemplo, explicando o porquê de Sussuarana no título:

Ela costumava cantar uma canção, Sussuarana, que nos emocionava adolescentes e não sabia o autor, a origem, acho que ela criou a música depois Gal gravou e em Los Angeles, 15 meses antes da morte de Necy; as letras surgiram criando Riverão Sussuarana no pressentimento dum romance que tornasse Homem aquela Onça que saltou de mim no Domingo crepuscular na llha (Riverão, p. 199).

A presença de Anecy será construída, a partir de então, de vários modos em Riverão Sussuarana. No excerto acima, e em vários outros, ela acena como inspiradora da obra - "15 meses antes da morte de Necy, as letras surgiram criando Riverão..." -.

Ao mesmo tempo, ao contrário de Glauber-repórter, que assume um papel de ator narrativo, Glauber-autor se identifica com actante destinador transcendente. Como explica Luis Tatit (Linguística - USP), em Semiótica à Luz de Guimarães Rosa, o destinador transcendente "possui um estatuto especial" e

Representa uma função transitiva responsável pelo projeto maior do sujeito: sua constante busca de junção. Esse destinador articula disjunção e conjunção como estágios de um mesmo processo que mantém o sujeito em continuidade. Propõe logo a sutura em lugar da fratura. Difere portanto - já que pertence a um nível mais profundo -- do manipulador e do julgador (embora possa eventualmente manifestar-se como tais), que constituem, respectivamente, etapas inicial e final do percurso narrativo. $O$ destinador transcendente paira sobre todas as operações executadas e as paixões vividas pelo sujeito ao longo de sua trajetória. Ele acolhe as interrupções como elementos indispensáveis à continuidade. É por seu intermédio, 
pela força transitiva de sua atuação, que as narrativas não param. (Tatit, 2010, p.20)

Principal responsável por manter a trama caminhando, a parada desse destinador significa a interrupção da narrativa. Glauber-autor irrompe a enunciação com sua dor: ante a morte, sua impotência é absoluta. Um acontecimento capaz de "arrebentar a estrutura de Riverão Sussuarana", trazendo esse destinador que, até então, pairava sobre "todas as operações executadas e as paixões vividas pelo sujeito". Em termos substanciais, a "musculatura emocional" desse sujeito, matéria-prima de qualquer composição poética que é o estado de alma do autor da obra, expressa-se na composição heterogênea, veloz e sob notória ilogicidade do fluxo de consciência abaixo:

ROMANCE M: CHAVES: lembro-me que no DOMINGO FATAL fui ao apartamento conservar (Sic.) com o marido e meio dia voltamos pro almoço na casa de meus pais.

Saímos pela porta da cozinha, a porta foi trancada, ÊLE TROUXE A CHAVE?

QUANDO SEGUNDO RELATO DA VIZINHA NECY SUBIU SEM CHAVE E TENTOU ABRIR A PORTE DA COZINHA COM A CHAVE DE FENDA COM QUEM ESTAVA A CHAVE?: e se estava com o marido e

ÊLE NÃO LHE DEU A CHAVE PORQUE?

$(\ldots)$

PORQUE ELA ESTAVA NERVOSA: aqueles dados forneciam suspeitas, pelo menos a hipótese de versão mal contata, mas se criou uma barreira repressora de amigos\&PARTEDAFAMILIA: impedido de prosseguir, ainda fui proclamado louko por funcionários da TV E ALGUNS NEO:FASCISTAS QUE SE PROCLAahayor troiys: fui para

BRASYLYA NA CRISE DOS PACOTES

CONGRESSO fechado

ATO V

ferido nos braços de

OLYVEYRA BASTOS: POLYTYKA E CRIME NA SEMANA SANTA: documentos? O GOLPE DE -: novas contradições 
TEATRO HYPOKRYTA PARLAMENTAR: revisar as estruturas do sistema que jogou

NECY NO FUNDO DO ELEVADOR: este Discurso revelado me projetou na fama da Loukura mas a POLYTYKA SE FEZ VERBO NA PRIMEIRA PESSOA: O engordamento da Onça, a espessura mytyka de

SUSSUARANA SELVAGEM E RIVERÃO civilizado, equilíbrio das extremidades, petróleo sanguinário, sono sonhador e feliz, despertar diante dum mar fétido e arvores brilhantes na

THAPLUS CVIII RUMO A VESPER

ESTRELA NECY E SEIS EXERCITOS SE MOBILIZAM LIVERTANDO O GIGANTE ETERNAMENTA ADORMECIDO

(Riverão, p.192-193)

O excerto acima é marcado pela confluência de isotopias figurativas distintas - a tragédia familiar (em vermelho), o contexto político e cultural de produção da obra (em azul) e comentários metalinguísticos (em verde) -, e pela alternância dos discursos indireto e direto, criando ambiente necessário à justaposição de várias versões sobre a morte de Anecy, a partir da fala de familiares, trabalhadores do prédio, policiais.

Esse fluxo de pensamentos, como notamos pela iteração do termo "chave", conflui para a versão não acidental da morte, em hipótese totalmente descartada por amigos e familiares do autor, inclusive dá-se a construção de barreira visual, expressa pela combinação das palavras em uma única "amigos\&PARTEDAFAMILIA" - Daí a "fama de louco", da qual Glauber se queixa diversas vezes ao longo da obra. O que temos é uma clara tentativa, em meio à inexorável ilogicidade da morte, de encontrar uma "causa", um "culpado", enquanto desesperada recusa da perda, expressa na confusão de pensamentos do discurso acima, marcado pela iteração dos episódios relacionados à morte; e busca de restauração de um equilíbrio ante a perda do estado de conjunção entre Glauber e Anecy, irmão e irmã, sujeito e objeto de valor.

O luto é construído pela articulação de temas e figuras que nos remetem à isotopia da morte (luto e perda pessoal) e, também, à opressão da liberdade 
(restrição das liberdade democráticas e coletivas), a partir do imbricamento de uma série de episódios referenciados do contexto político (fechamento do Congresso, Al-5, Golpe, teatro hipócrita parlamentar) com os episódios relativos à morte de Anecy. A narrativa se constrói sob a égide desse duplo trauma (a morte e a ditadura) em engrenagem de crescente ilogicidade, como vemos na associação entre o elevador e o país: "incapaz de revisar as estruturas do sistema que jogou NECY no fundo do elevador". Não há fora e dentro, apenas o discurso que, tal como um rio, carrega o que encontra em suas margens. A razão e a desrazão se complementam e são construídas pela aceleração do fluxo verborrágico de palavras, enquanto correnteza prosódica (ora calma, ora agitada), conforme sugere a alternância entre maiúsculas e minúsculas na grafia desse vocabulário autoral, que reforça ainda mais a presença física do enunciador, indício da substancialidade.

Construído no discurso, o luto será raiva, desespero, acusação na construção do diário íntimo, do inquérito policial, da notícia de jornal, obsessivo quanto aos detalhes sobre o dia da morte de Anecy. Será também tristeza e saudade no discurso memorialístico, abrangendo outras perdas e traumas familiares, em uma corajosa exposição da privacidade. Enquanto construção discursiva, esse luto será superado no discurso poético, o espaço da liberdade plena, onde Glauber dará vida à voz de Anecy, construindo um último diálogo entre irmãos, ao incorporar na narrativa de Riverão Sussuarana, trechos do conto "Para meu marido", atribuído a ela e publicado na íntegra, em três momentos diferentes da obra. Um procedimento possibilitado pela confluência de gêneros textuais (do diário ao artigo / do conto ao poema) que compõe a linguagem verbal do romance.

Chegou em casa às 3:15. O marido ainda não tinha dormido. Eles se abracaram e dormiram de mäos dadas. Finalmente a paz tomou Ana devagarinho e foi assim por toda a noite.

Era o Descobrymento do Brazyl!

Riverão esquipou no Mapa do Territorio: seu um era um chãozinho limitado da Ryo Bahia mas coração muito largo, vastidões.

(Riverão, p.210) 
O que vemos acima é um desses momentos de alternância entre a escritura (fluxo de pensamento) de Glauber e a de Anecy (conto). Inserido em itálico e disposto em três partes, o conto se entremeia ao fluxo de consciência, articulando estilos, ritmos, vocabulários e campos discursivos totalmente diferentes. $O$ encontro entre essas duas vozes, visualmente demarcado pelo itálico, atua como conjunção (im)possível com o objeto de valor encontrada por esse sujeito dilacerado.

Em meio ao discurso referencial, e aos poucos, o discurso mítico retoma é restaurado, incorporando o luto, como vemos no excerto abaixo, quando o sujeito Riverão toma as rédeas da história, assumindo o papel de interlocutor em discurso direto:

Riverão assoviou:

-- Seu Grobe está com a morte da irmã na cabeça. Veio me contando durante a viagem seu sofrimento. Me recitou uma Poezya e peço sua atenção:

"Não esqueço tua face gloriosa morta

Dentro do caixão amarelo entre amigos Parentes e amantes de tua breve passagem pela vida... Minha irmã querida...

Eras a poesia viva...

Branca de Neve...

Ninguém mais linda em graça e beleza...

Eras ágil como as cabras borboletas.

Nega Fulô
Jogralesca

Teu sorriso de gloria sobre a morte

Do ângulo que te vi, beijei, falei em teu frio cadáver

Eras o pique das Amazonas, guerreira morta em ação.

(Riverão, p. 206)

Agora, a morte de Anecy é absorvida pela dimensão mítica da caravana de jagunços. Novamente dá-se a composição de dois gêneros discursivos: o 
romance e o poema. A subversão, porém, é completa: acenando aspectos de metalinguagem, Riverão, sujeito do percurso narrativo, concede voz ao destinador transcendente da obra, e não o contrário, como o esperado. É a criatura que lê o poema do criador. E nisto reside uma das centrais reflexões propostas por Glauber: a relação de amor entre autor/obra, criador/criatura, Glauber e Rosa, Rosa e Riverão, Riverão e Glauber, em franca afirmação de sua filiação literária.

A substancialidade em Riverão Sussuarana é construída a partir da alternância dos actantes da enunciação (narrador, enunciador e interlocutor), a partir de enunciação reportada (com marcas da enunciação), enunciado enunciativo (sem as marcas) e enunciação enunciada (quando a obra é tematizada), na confluência de diferentes regimes de construção semiótica: o mítico, vocalizado pelo ator da narrativa (Glauber-repórter) em embreagem enunciativa, relativo à mítica sertaneja, figurativizada na caravana de jagunços; o referencial, protagonizado pelo sujeito Glauber-autor, que se identifica com o destinador transcendente da obra, em embreagem enunciativa, promovendo brutal parada na narrativa. É do contrate entre eles que irromperá o regime o substancial propriamente dito, afirmando a referencialidade e negando a mítica.

Para além dessa ruptura, resultante de acontecimento trágico que expõe e de modo radical (e a partir de conteúdo íntimo), o entorpecimento emocional desse enunciador, a substancialidade em Riverão Sussuarana também resulta da presença física desse enunciador, construída por vertiginoso imbricamento de vozes que apontam para o signo Glauber Rocha, autorreferenciado em diferentes percursos narrativos. Em Glauber, Labirinto do Brasil (Tendler, 2003), o ator Hugo Carvana, ao contar sobre sua experiência com o cineasta, ajudanos a vislumbrar a presença dessa substancialidade em Riverão:

Naquela época os filmes eram dublados, então, ele interferia permanentemente, ele interferia permanentemente, pra um ator é um horror você estar fazendo uma cena e se o plano era fechado ele ficava aqui, ele ficava aqui a um palmo de distância, ou a dois palmos de distância dizendo "CHORA". "GRITA". GRITOS. Entendeu? Ele rompia tudo aquilo que eu sonhava, pausa, silêncio, entendimento, emoção, técnica, relação com a lente, e veio o Glauber e explodiu as lentes, quebrou as lentes, lá foram as 50 , as 18 , as 75 pelos ares. (Tendler, 2003, 45'19") 
Com esse mesmo megafone, agora a um palmo do leitor, a onipresença de Glauber se faz sentir. Convocado ao jogo sensorial desse enunciador manifesto por todos os lados, o enunciatário, enquanto sujeito estésico, ou seja, dotado da capacidade de apreensão do sensível, será mobilizado pelas sucessivas correlações entre os planos de expressão e de conteúdo, por onipresença que parece almejar o transe, em seu fluxo contínuo de razão e desrazão.

O desnudamento de Glauber é caminho sem volta. Ao se bifurcar, promovendo a parada que nos lança não em direção ao universo mítico (como em PanAmérica) mas em direção à referencialidade, ele se torna protagonista de uma exposição visceral da intimidade, em violento desmembrar das camadas enunciativas. Em várias perspectivas sobre si mesmo, Glauber assume o papel de um enunciador paralisado frente um autor impossibilitado de continuar o discurso, devido ao desespero, raiva, tristeza. Daí os gritos (letras em maiúsculas) e todo trabalho, em termos de plano de expressão, com a "materialidade" dessa prosa que engloba textos escritos e falas dessa irmã, fazendo da narrativa substancial, o espaço de conversa entre ambos.

Resultante da combinação de gêneros e temas diversos lançados freneticamente sobre o leitor, é possível identificar temas e figuras que, simultaneamente nos remetem a aspectos políticos, culturais e sociais, constituindo o panorama contextual da obra, em última instancia, o seu arquitexto; e ao mesmo tempo, o panorama tímico, os aspectos relativos ao estado desse sujeito, da alegria inicial ao desespero que o faz interromper a trama. Essas tensões serão revestidas pela verborragia barroca de Glauber, capaz de deglutir, de modo mais contínuo (menos vírgulas, menos experimentações ortográficas) ou não, o pensamento crítico de uma geração que mudou os paradigmas do mundo, entre 1960 e 1970. Esse é o universo temático de uma escritura guiada pela predominância da prosódia sobre a sintaxe, e ritmada pela cadência, em um fluxo de consciência que desbrava a desrazão, o transe e, última instância, a mística revolucionária que afirma a liberdade em oposição a qualquer opressão. 
Uma mística que fazemos questão de reiterar, na medida em que ela constitui uma proposta estética e revolucionária, concebida em Estética do Sonho (1971) como:

Arte revolucionária deve ser uma mágica capaz de enfeitiçar o homem a tal ponto que ele não mais suporte viver nesta realidade absurda. Esta raça, pobre e aparentemente sem destino, elabora na mística seu momento de liberdade. Os Deuses Afro-índios negarão a mística colonizadora do catolicismo, que é feitiçaria da repressão e da redenção moral dos ricos. (Rocha, 1971, online) 


\title{
4. A significação no romance experimental
}

1925. Um ano após o Manifesto Surrealista de André Breton e em plena efervescência das vanguardas artísticas, o filósofo José Ortega y Gasset publicava o ensaio A desumanização da Arte (1925), observando como as vanguardas artísticas, em um caminho sem volta, libertaram os artistas da representação realista do mundo, fundando uma nova sensibilidade sob a premissa de que estilizar significa deformar o real. Mal recebidas, as obras de vanguarda demandavam do público de então, majoritariamente acostumado à "realidade vivida", explorada pelo Romantismo e pelo Realismo, uma "realidade artística" que, por sua vez, demanda tempo e repertório.

Segundo o filósofo, para esse público não familiarizado com as vanguardas, o prazer estético não se constitui "atitude espiritual diversa em essência da que habitualmente [ele] adota no resto da sua vida"; e o que essas pessoas buscam na arte é "o mesmo que [encontram] na existência cotidiana: figuras e paixões humanas" (Ortega y Gasset, 2001, p. 26)". Defensor da "realidade artística" Ortega y Gasset é categórico ao afirmar que

\begin{abstract}
Alegrar-se ou sofrer com os destinos humanos que, talvez, a obra de arte nos refere ou apresenta é algo bem diferente do verdadeiro prazer artístico. Mais ainda: essa ocupação com o humano da obra é, em princípio, incompatível com a estrita fruição estética (...) O objeto artístico só é artístico na medida em que não é real (idem, p.27).
\end{abstract}

Para explicar a diferença entre essas duas realidades, a vivida e a artística, ele traz a alegoria de um jardim atrás de um vidro que adotaremos para expressar as nuances entre os diferentes regimes de construção semiótica nas narrativas experimentais.

Diante desse jardim nós temos duas opções: ou fixamos o olhar nele, esquecendo a presença do vidro; ou nos fixamos no vidro, turvando a imagem do jardim ao fundo. Enquanto metáfora dos procedimentos artísticos, o vidro se vincula à realidade artística, e o jardim aos "aspectos humanos que motivam 
alegria ou sofrimento" (ibidem), e que estão relacionados à realidade vivida das pessoas.

É sobre essa tendência (de não ver o vidro) que as práticas experimentais incidem, e sua didática consiste em tornar perceptíveis os procedimentos da linguagem automatizados pela leitura, através do contraste e do estranhamento que promovem durante o processo de desumanização que caracteriza a estilização. Nas palavras de Ortega e Gasset, essas obras são movidas por uma "vontade de estilo", sendo que toda

estilização implica desumanização. E, vice-versa, não há outra maneira de desumanizar além de estilizar. O realismo, ao contrário, convidando o artista a seguir docilmente a forma das coisas, convida-o a não ter estilo (ibidem, p.47).

Neste ensaio, Ortega y Gasset também observa a perda de transcendência das vanguardas, mais especificamente do seu caráter hierático, de sua grave importância, do seu "patetismo", levando à libertação dos artistas do jugo de "salvadores do mundo":

A primeira consequência que traz consigo esse retraimento da arte sobre si mesma é tirar desta todo o patetismo. Na arte carregada de " humanidade", repercutia o caráter grave anexo à vida. Era uma coisa muito séria a arte, quase hierática. Às vezes pretendia nada menos que salvar a espécie humana - em Schopenhauer e Wagner. Pois bem, não é de estranhar, a quem pensa sobre ela que a nova inspiração é sempre, inexoravelmente, cômica. Toda ela soa nessa única corda e tom. A comicidade será mais ou menos violenta e correrá desde a franca clowneria até a leve piscadela irônica, porém não falta nunca. E não é que o conteúdo da obra seja cômico - isto seria recair num modo ou categoria do estilo "humano" -, mas sim que, seja qual for o conteúdo, a própria arte se torna chiste. (ibidem, p.76)

Por trás dessa não-transcendência incide o abandono, também, da pretensão de representação realista do mundo, visto pelo filósofo como expressão de "um profundo respeito à vida e uma repugnância de vê-la confundida com a arte" (ibidem, p.53): 
A aspiração à arte pura não é, como se costuma crer, uma soberba, mas sim, pelo contrário, uma grande modéstia. A arte, ao esvaziar-se do patetismo humano, fica sem transcendência alguma - como apenas arte, sem mais pretensão (idem, p.82).

É desse "asco do humano", dessa representação falsificada que a literatura de Mallarmé procura nos libertar, aponta Ortega y Gasset; e a partir desse momento, "vai-se à arte precisamente porque a reconhecemos como farsa":

\begin{abstract}
Seria "farsa" - no mau sentido da palavra - se o artista atual pretendesse competir com a arte "séria" do passado e um quadro cubista solicitasse o mesmo tipo de admiração patética, quase religiosa, que uma estátua de Michelangelo. Porém o artista de hoje nos convida a contemplar uma arte que é um chiste, que é, essencialmente, o escárnio de si mesma. Porque nisto radica a comicidade dessa inspiração (ibidem, p.76).
\end{abstract}

Essas questões trazidas pelo filósofo, no despontar das vanguardas do século $X X$, permitem a reflexão sobre os paradoxos dessa não-transcendência, afinal, os artistas de vanguarda, ao equipararem os planos de expressão e de conteúdo, da realidade artística e da realidade vivida, ambos indissociáveis como nos ensina o pensamento saussuriano, afirmaram a autoconsciência criadora e crítica (cf. Paz) que mudaria a sensibilidade estética do século XX.

Deste lado do Atlântico, a prática experimental - fortemente presente, inclusive, em termos de cânone literário - será intensificada, como vimos anteriormente, por duas vanguardas: as do começo do século $\mathrm{XX}$, que Ortega y Gasset observa no calor da hora, e que inspiraram definitivamente o nosso Modernismo; e as neovanguardas do pós-Guerra, em particular, as que permitiram reapropriações e releituras da antropofagia de Oswald de Andrade, tanto em termos de produção crítica (Antonio Cândido entre outros) quanto de diálogo artístico (Tropicália, Teatro Oficina, Cinema Novo). E, é sempre bom lembrar, devido ao esforço de formação política e cultural capitaneada pelos Centros de Cultura Popular (CCP) do então Partido Comunista Brasileiro (PCB) que, criticados ou não, foram incontestes propulsores de uma inteligência crítica 
e artística no país, inserindo a temática do povo, das desigualdades sociais e regionais, dos sistemas de exploração na sociedade brasileira.

PanAmérica, Zero e Riverão Sussuarana, embora distantes da racionalidade e das palavras de ordem do CCP, como pudemos ver no capítulo anterior, foram concebidas nesse arcabouço cultural, em contexto de repressão dessas ideias. Experimentais em suas composições, essas obras não pertencem a nenhum movimento literário -- aliás, boa parte das experimentações na prosa nacional compõem a comunidade inoperante e independente de escritores, defendida por Tabarovsky -, embora centrifuguem esse ambiente cultural, propondo, e de modo antropofágico, releituras as mais diversas. As influências vão desde práticas experimentais e estéticas das vanguardas e neovanguardas (movimento pop, pensamento em rede do movimento hippie, temática da contracultura, prática da Tropicália, a inspiração do Cinema Novo); à vivência do autoritarismo de Estado no contexto da Guerra Fria, que teve no território latinoamericano um de seus campos de batalha. Daí a resistência política, cultural, comportamental, de forte impacto na produção literária daquele período.

A adoção da linguagem experimental por esses autores, bem como o revestimento da oposição opressão vs. liberdade no nível fundamental do plano de conteúdo dessas obras expressa esse diálogo. Tampouco é aleatória a presença dos Estados Unidos ou de alguma característica daquele país no revestimento figurativo do antissujeito nas três narrativas: em PanAmérica, o sujeito mata o adido norte-americano responsável pelas torturas no continente; e até a invasão norte-americana é reconstruída. Em Zero, as cenas finais se passam numa prisão norte-americana, discutindo inclusive a geopolítica no continente; em Riverão, a caricatura do antissujeito Karter Bracker é o estereótipo do imperialista norte-americano, principal inimigo de Glauber Rocha. Em contrapartida, a ascendência latino-americana é reivindicada, inclusive, PanAmérica traz o sonho de Bolívar em seu título.

Embora pareçam debochadas, engraçadas, surrealistas, essas obras lidam com o trágico e o fazem a partir da crítica e da autocrítica, característica da modernidade que "nunca é ela mesma: é sempre outra" (Paz, 2013, p.15). E mesmo quando optam pela hipérbole e pelo delírio figurativo, pelo humor ácido 
e debochado, essas obras, injustamente caracterizadas como "alienadas", expõem as contradições políticas, sociais e comportamentais do seu contexto, em particular as violações, ameaças, exílios em curso. Esse é, inclusive, o repertório dos temas e figuras de seu plano de conteúdo. Não se trata de crítica velada, mas da citação aberta, ousada em tempos de censura brutal.

De modo geral, as três obras trazem (1) conteúdo histórico referenciado em figuras e temas, (2) conteúdo metalinguístico em termos de enunciação reportada, e (3) conteúdo narrativo, a enunciação enunciada ou enunciado enunciado do percurso narrativo da obra. Três repertórios imbricados nestes textos, de modo experimental, fragmentado, acelerado, construindo o efeito de vertigem e avalanche polifônica. Com isso, afirma-se a ideologia estética da Tropicália e das neovanguardas do período, bem como sua performance de resistência política - todas denunciam a ditadura em seu plano de conteúdo, o que não é pouca coisa -. Esses temas e figuras, por sua vez, serão articulados de modo experimental, o que significa, inerentemente, problematizar o modo tradicional de expressão, instaurado enquanto "outro discursivo" com quem o diálogo experimental é estabelecido.

Como explica Gonzalo Aguilar, docente da Universidade de Buenos Aires, em Poesia Concreta Brasileira: as Vanguardas na Encruzilhada Modernista (2005), esse diálogo nas vanguardas resulta em "não conciliação", na medida em que essas obras irão questionar o estatuto tradicional da obra "de um modo integral" e com capacidade de promover mudanças "na circulação, produção e recepção dos produtos artísticos" (idem, p.33). É neste sentido que Aguilar defende, aos moldes de Paz (cf. Paz, data), que as vanguardas não destroem o passado, mas renovam o legado da tradição, guiadas pelos interesses do presente:

As vanguardas não negam a tradição, simplesmente a transformam de sujeito em objeto, de diacronia reverenciada em sincronia estratégica, de história necessária em intervenção artificial (Aguilar, 2005, p.40).

Fazendo da tradição seu "objeto", elas a transformam questionando as coerções da língua, cientes do inerente fascismo (Barthes) da linguagem e do fato de que "os sujeitos não escolhem 'livremente seus discursos" (Maingueneau, 2008, 
p.62). Há sempre um discurso dado sobre o qual nós construímos ou reconstruímos a realidade do mundo.

\section{- Questão de ideologia}

A semiótica narrativa diferencia dois conceitos: o de ideologia e o de axiologia. Ensina-nos o Dicionário de Semiótica, que axiologia é

a teoria e/ou a descrição dos sistemas de valores (morais, lógicos, estéticos).

(...) o modo de existência paradigmática dos valores por oposição à ideologia que toma a forma do arranjo sintagmático e actancial deles. Pode-se considerar que qualquer categoria semântica representada no quadrado semiótico (vida/morte, por exemplo), é suscetível de ser axiologizada, mercê do investimento das dêixis positiva e negativa pela categoria tímica euforia/disforia.

(Courtés, Greimas, 2016, p.48)

Essas axiologias (ou microssistemas de valores) podem ser abstratas (vida/morte) ou figurativas (os quatro elementos da natureza, por exemplo). A ideologia, por sua vez, é composta por valores virtuais que "resultam da articulação semiótica do universo semântico coletivo". Esses valores pertencem ao nível das estruturas semióticas profundas, quando eles se atualizam, ou seja, quando são assumidos por um sujeito, (individual ou não), eles passam por uma modalização em torno de um "querer-ser" e, subsequentemente, de um "quererfazer" (idem, p.48). Neste sentido, ideologia pode ser definida como

uma estrutura actancial que atualiza os valores que ela seleciona no interior dos sistemas axiológicos (de ordem virtual). Uma ideologia se caracteriza então pelo estatuto atualizado dos valores que assume: a realização desses valores (isto é, a conjunção do sujeito com o objeto de valor) extingue, ipso facto, a ideologia enquanto tal. Em outros termos, a ideologia é uma busca permanente dos valores e a estrutura actancial que a 
informa deve ser considerada uma recorrente em todo discurso ideológico (idem, p.253).

Em seu artigo, "L'idéologie réactualisée dans la sémiotique de Greimas" (2020), Nijolé Keršyté (Institut de Recherche sur la Culture de la Lithuanie - LKTI) esmiúça a questão da ideologia na teoria greimasiana, mostrando como ela nos permite analisar o processo pelo qual uma ideia se transforma em ação. Em sua definição de ideologia, aponta Keršyté, Greimas diferencia "modelos ideológicos" e "modelos axiológicos" ou "sistemas de valor", que constituem "o quadro no qual se inscrevem culturas inteiras ao seio das quais nós vivemos" (2020, p.73).

Essa distinção se relaciona às oposições saussurianas, em particular, a da língua (enquanto sistema) e a da palavra (enquanto realização individual desse sistema). Dentro dessa concepção, axiologia é o sistema virtual estático e se relaciona com os elementos paradigmáticos (personagens e actantes), já a ideologia é a realização dinâmica do sistema, e diz respeito aos elementos sintagmáticos (a ação, os comportamentos). "A ideologia concerne a dinâmica: os algoritmos, as ações", sintetiza Keršyté. Em sua avaliação, Greimas amplia "o campo da ideologia para além das práticas da sociedade burguesa", invertendo o pensamento existencialista: nós não estamos condenados ao "não sentido" das coisas, mas sim à significação de todas as coisas (ibidem, p.76).

Neste sentido, ideologia é "uma ação orientada em direção a um ou vários valores (ou 'objeto de valor) que pressupõe um sistema de valor, uma axiologia", e neste sentido, a ideologia é uma busca permanente por valores (idem, 81). Assimilando o conceito de ideologia da antropologia, enquanto "sistema de ideias que se exprimem não em conceitos, mas por imagens", Greimas irá utilizar os termos mito / ideologia com base na distinção entre figurativo / conceitual; ampliando o campo recoberto por mito, identificado como discurso figurativo e englobando desde "mito antigo ou um conto popular, ou um poema literário" (idem, p.27). Do mesmo modo, explica Keršyté, o campo da ideologia é estendido para além do poder político e social: ideologia é, em linguagem abstrata, "uma maneira mitificante" mais ou menos figurativizada. Mito e ideologia são, portanto, dois modos de dizer "uma única e mesma coisa (idem, 
30). Daí a utilização por Floch do termo "ideologias" referencial, mítica, substancial e oblíqua, em sua análise do discurso publicitário.

Passar do mítico ao ideológico, aponta Keršyté, significa traduzir a linguagem figurativa (mítica) em termos abstratos (conceituais) para revelar 0 que o mito significa. Em outras palavras, "a enunciação de sua significação será justamente a tradução de cada mitologia em uma ideologia" (idem, p.31). Essa tradução também ocorre na passagem do nível figurativo para o narrativo. Em termos narrativos, o conceito de ideologia se encontra ancorado na lógica da ação de suas estruturas narrativas, onde é possível identificar os actantes da enunciação e do enunciado (idem, p.16). Ao analisar essas obras (cf. capítulo 3 ), nós procuramos demitificar essas ideologias. Esse processo de demitificação diz respeito a descrever "a poesia, a religião, os valores morais, a arte, interrogando o que tudo isso significa" (idem, p. 34).

Os três autores do nosso corpus viveram o ambiente cultural, social e político dos anos 1950, 1960, 1970. Bem posicionados em suas áreas de atuação, eles optaram por exprimir suas experiências naquele contexto, de modo não convencional, optando por uma radicalização dos procedimentos artísticos. Daí o cinema-livro em PanAmérica, com várias cenas egressas de outras cenas, constituindo um labirinto referencial entre as linguagens da literatura e do cinema. A "prosa concreta" em Zero, composta por microcapítulos de um parágrafo alternados com cinco laudas de texto corrido. É a heterogeneidade que predomina. Apesar dessa "independência", cada unidade cênica acontece no mesmo agora enunciativo. Embora não pareça existir uma trama, um enredo narrativo, ele existe e coexiste com outras pequenas tramas, por exemplo, a série Adeus, Adeus que, como vimos anteriormente, faz menção aos exilados pela ditadura.

Observar a construção dos regimes de realidade nessas narrativas nos ajuda a "demitificar" as ideologias imbricadas em seu processo discursivo e narrativo, e a compreender as estratégias de manipulação do enunciador sobre o enunciatário. Em nossa visão, a adoção da linguagem experimental é uma estratégia de manipulação que passa, no caso do corpus aqui analisado, por uma performance de enfrentamento dos silenciamentos do período, revestindo 
temática e figurativamente a ameaça de um não-poder-fazer (impotência) ou de um não-poder-não-fazer (obediência) e a busca por um poder fazer (liberdade) e um poder-não-fazer (independência).

A resposta a essa tensão está impregnada no plano de expressão dessas obras, construído como avalanche polifônica em reação à violência do nãopoder-dizer, resultante inclusive da paranoia da vigilância, afinal, não se trata apenas do discurso oficial da opressão, mas do seu espraiamento no discurso cotidiano (do trabalho, do jornal, das festas, das revistas e, poderíamos desdobrar o da internet, das redes sociais, das conversas de elevador). O nãopoder-dizer da realidade vivida será nessas obras subvertido pelo poder-dizer da realidade artística, e ele será o dizer verborrágico e plural dos fluxos de pensamentos, das justaposições contínuas. A pluralidade de discursos jorrado por cada uma dessas obras escapa ao alinhamento do discurso único da ditadura no país.

É contra a apatia de uma sociedade vigiada e submetida à violência permanente desse discurso, que esses artistas - e tantos outros naquele momento - encontraram na linguagem verbal, meios de expressar a fratura (corte, rasgo, ruptura) e a desagregação (estilhaçamento, despedaçamento, desmembramento) de um modelo de sociedade, marcando em seu plano de expressão sucessivas descontinuidades exaustivamente trabalhadas em seu plano de conteúdo. Ante a ameaça contra a liberdade, esses textos, como nenhum outro, procuraram convencer o enunciatário a se tornar se não sujeito histórico do processo revolucionário, pelo menos sujeito interpretativo do mundo.

Daí a questão: como ler o experimental?

O que nós iremos propor neste capítulo é um caminho - entre outros, naturalmente - de entrada nessas obras, por meio de uma tipologia que irá observar como o efeito de sentido da realidade é construído na linguagem verbal ou sincrética, permitindo uma abordagem mais demitificadora e menos desmistificadora $^{38}$ da pulsante produção experimental no romance brasileiro contemporâneo.

${ }^{38}$ Greimas estabelece a oposição entre os termos "demitificadora", em busca da ideologia de cada mito; e desmistificadora, que abrange caráter acusatório e moralizante. 


\section{- Coautoria}

Muito mais coautor do que leitor, o enunciatário a quem se destina o texto experimental é permanentemente instado a identificar as sucessivas perturbações na narrativa; e a permanecer a reboque dos acontecimentos, sem qualquer possibilidade de previsão quanto ao rumo dessas tramas, na medida em que seus personagens e temas se desenvolvem no desenrolar dos acontecimentos (Floch, 1990, p.202-203). Conforme nos ensina Barros, todo enunciatário é manipulado por um enunciador que, assumindo o papel de destinador-manipulador, tem como fazer persuasivo transformar o leitor em destinatário-sujeito capaz de um fazer interpretativo (Barros, 1988, p.92-3).

No caso dos romances experimentais, esse processo dependerá da disponibilidade do enunciatário em ultrapassar o estranhamento resultante da quebra da linearidade, da subversão do código verbal, do jogo sincrético, dentre os mais variados procedimentos da prática experimental. Nisto consiste o primeiro gargalo desses romances, equivocadamente lidos e criticados sob o enfoque de textos não experimentais, e por isso descritos como narrativas "mal feitas", "chatas", “confusas", "difíceis", "radicais", "porra-louquice”, sem que sejam considerados os aspectos de sua semântica global. Daí a importância dos guetos de contracultura para a sobrevivência do experimental; e as oportunidades abertas pela virtualidade, tanto em termos de circulação da informação sobre esses autores e obras; como da própria produção experimental frente às inovações tecnológicas do livro-objeto, das possibilidades de interação enunciador-enunciatário, entre outras.

Diante de obras experimentais, o sucesso da manipulação do enunciador sobre o enunciatário dependerá do contrato fiduciário entre ambos, definido como contrato de veridicção e nos permitindo identificar o discurso como verdadeiro, falso, mentiroso ou secreto. Tudo depende, portanto, da capacidade desse enunciatário em transpor o estranhamento e desse enunciador de persuadi-lo, fazendo com que ele encontre "as marcas de veridicção do discurso", compare-as com seus "conhecimentos e convicções, decorrentes de 
outros contratos de veridicção"; "e creia, isto é, assuma as posições cognitivas formuladas pelo enunciador" (idem, p.94), afinal,

O enunciador não produz discursos verdadeiros ou falsos, mas constrói discursos que criam efeitos de sentido de verdade ou de falsidade, que parecem verdadeiros. $O$ parecer verdadeiro é interpretado como ser verdade, a partir do contrato de veridicção assumido (ibidem).

É por isso que o enunciador Glauber Rocha pode se desdobrar em três vozes, e assumir dois personagens (Glauber-repórter e Glauber-autor) distintos sem prejuízo à nossa compreensão da obra; afinal, não se trata de "Glauber" um ser como nós, mas da força de realidade do "dizer verdadeiro" desse enunciador, narrador e interlocutor Glauber Rocha.

A persuasão do enunciatário, naturalmente, não se restringe ao discurso poético. Tanto o discurso da História quanto o da ficção, ou o discurso político constroem uma verdade e um fazer persuasivo sobre o enunciatário, seja o fazer cognitivo (da ordem do saber e do crer), próprio dos discursos literário e científico; seja o fazer pragmático (o fazer-fazer) próprio dos discursos publicitário e político (fazer consumir, fazer votar ou fazer crer), aponta Barros. O que caracteriza, no entanto, os discursos literários é que seu fazer cognitivo irá se construir, predominantemente, no processo de figurativização:

O enunciador utiliza as figuras do discurso para fazer-crer, ou seja, para fazer o enunciatário reconhecer "imagens do mundo" e, a partir daí, a verdade do discurso. O enunciatário, por sua vez, crê-verdadeiro (ou falso ou mentiroso ou secreto), graças ao reconhecimento de figuras do mundo natural. $O$ fazer-crer e o crer pressupõem, conforme foi visto, um contrato fiduciário de veridicção, que regulamenta o reconhecimento das figuras. (Barros: 1988, p. 98)

O modo como essas figuras são articuladas é questão-chave no contrato veridictório entre enunciador e enunciatário. 
Se nas artes plásticas, o reconhecimento das figuras do mundo é perpassado pelo diapasão figurativo vs. abstrato, em que a iconicidade acena enquanto efeito de sentido resultante do contrato de veridicção (Barros, p.98); no discurso verbal, a oposição referencial vs. mítico nos permite observar os termos desse contrato veridictório, com base na manipulação (fazer-crer e fazersaber) exercida sobre o enunciatário. No capítulo 3 , nós pudemos observar a manifestação de três desses quatro regimes no discurso poético: a referencialidade em Zero, a obliquidade em PanAmérica e a substancialidade em Riverão Sussuarana.

O que mostraremos, a partir de agora, é como esses regimes nos permitem, de modo mais amplo, reconhecer diferentes tipos de experimentalismos no romance contemporâneo. Nossa proposta se ancora na observação de como são construídos os efeitos de realidade (ou de irrealidade) nessas obras. O mesmo modelo é válido tanto para poéticas experimentais quanto para as não experimentais. No caso das experimentais, esses quatro regimes podem ser identificados, no entanto, haverá uma predominância entre eles.

Para observar o fenômeno da experimentação na linguagem verbal, nós optamos por um conjunto de obras dotadas de certa homogeneidade adotando um corpus que nos permite circunscrever uma temporalidade (a ditadura militar), um espaço geográfico (Brasil), um gênero (romance) e uma performance (resistência) comuns. Cada obra, ao mesmo tempo, surge em contexto de expectativa distinto quanto à correlação de forças entre opressão e liberdade: PanAmérica é publicada em 1967, quando, apesar da repressão, a resistência à ditadura ainda podia ser verbalizada; Zero, em 1975, em pleno silenciamento e brutalidade do regime; e Riverão Sussuarana, em 1979, na expectativa de uma abertura democrática que levaria ainda uma década.

Esse contexto, por sua vez, torna as experimentações ainda mais singulares, na medida em que são - e, em particular Zero - textos que assumem uma performance de afirmação da liberdade em contexto de opressão, propagando os valores do ideário vida e arte, arte e política, cultura e revolução. Daí a predominância de procedimentos experimentais capazes de transformar 
os silenciamentos (interditos e não ditos) do período em verdadeiras avalanches polifônicas. Para esses artistas, em 1967, 1974 ou 1978, não bastava apenas dizer, mas atordoar, chocar, chacoalhar esse leitor, convocando-o a conhecer a verdade sussurrada, sequestrada, presa, assassinada ou exilada pelo Estado. Aliás, a questão posta pelo experimentalismo ocorrido no Brasil dos anos 1950 a 1970, do poema-práxis a Riverão Sussuarana, por mais distantes que eles pareçam, é que a estilização assume uma performance política, ao mesmo tempo em que nos traz, por meio da interdependência de seus fragmentos, um panorama daquele momento.

Longe de ser um movimento literário, como o foi em Portugal, o que chamamos de "experimentalismo" constitui uma prática movida por uma concepção acrática de produção literária, fortemente presente no cânone literário. Daí a proposta dessa tipologia que nos permite ler esses textos, independente de seus movimentos literários, observando como são construídos os seus regimes de realidade. Vamos a eles: 


\title{
4.1. Regimes de construção do real
}

A partir da metáfora do jardim por trás do vidro, utilizada por Ortega y Gasset, podemos imaginar diferentes características desde "vidro escritural", reveladas pelas poéticas experimentais que, necessariamente, irão denunciar a presença desse vidro, permitindo-nos identificar quatro distintas ilusões de realidade, como podemos observar no eixo semântico abaixo, apresentado por Pietroforte em A significação da Pintura (2016), a partir do método desenvolvido por Jean-Marie Floch, em Sémiotique, marketing et communication (1990).

\section{Eixo de articulação semiótica}

\author{
Oblíquo \\ (negação do referencial) \\ PanAmérica
}

Referencial

Zero
Mítico

Grande Sertão: Veredas

\section{Substancial}

(negação do mítico)

Riverão Sussuarana

O eixo semiótico acima é construído a partir das relações de (1) oposição entre o regime referencial e mítico, que são excludentes, ou se é referencial ou se é mítico; (2) de contrariedade que originam os regimes oblíquo e substancial, sendo que o oblíquo negará o referencial e afirmará o regime mítico; e o substancial negará o mítico e afirmará o referencial; e (3) de complementariedade, entre os regimes mítico e oblíquo e os regimes referencial e substancial. 
Todas as poéticas aqui analisadas, assim como as narrativas experimentais são uma composição desses quatro regimes de realidades, no entanto, um deles será predominante.

\section{- O regime referencial}

O regime referencial é aquele que nos permite, apesar desse vidro escritural, enxergar o jardim e identificar suas folhagens. Poéticas referenciais, experimentais ou não, constroem suas figuras e temas de modo articulado com as imagens do mundo. No caso das experimentais, os efeitos de sentido de realidade serão potencializados na articulação de uma multiplicidade de perspectivas sobre as mais variadas realidades possíveis e das mais diversas formas.

Por conta dessa diversidade, as experimentações do regime referencial construirão sua ilusão de realidade a partir da construção de uma visão panorâmica sobre o real, como sabemos, uma construção discursiva. Para tal, serão criados no interior do discurso poético "gatilhos" de referencialidade, que operam enquanto referentes internos, a partir da introdução de índices de referencialidade ou "pedaços" de outros discursos, conforme variadas modalidades de transtextualidade. Esses discursos enxertados funcionarão como "provas" no contrato de veridicção entre enunciador e enunciatário.

Das aspas à paródia, a experimentação da referencialidade na linguagem verbal criará os efeitos de simultaneidade, e poderá abranger tanto campos discursivos antagônicos quanto complementares. Além de expressar variados discursos, as poéticas experimentais buscarão fazê-los das mais diversas formas possíveis. Tal como as obras cubistas de outrora, que procuravam abranger todos os ângulos de um mesmo fenômeno ou de vários fenômenos em dado instante, o experimentalismo em poéticas com predomínio da referencialidade trará o vislumbre de uma totalidade multifacetada, e necessariamente marcada pela descontinuidade do ato de leitura. 
A construção dessa polifonia tenderá a ser mais conservadora em termos de subversões do código verbal e, naturalmente, em seu processo figurativo, com isotopias ancoradas nas figuras do mundo. Neste sentido, os procedimentos experimentais do regime referencial irão incidir mais intensamente sobre a enunciação, em termos de sintaxe discursiva, engendrando várias formas enunciativas sobre o real.

Quando regidas pela ideologia referencial, as poéticas experimentais irão construir sua ilusão de realidade calcada na utopia da totalidade, constituindo visões panorâmicas sobre o real ou detalhadamente pontuais e específicas sobre dado aspecto da realidade. Neste sentido, essas poéticas tendem a se constituir verdadeiros arquivos de época, propondo encadeamentos os mais variados. Em Zero, a saga de José, o cenário e o percurso referencial são contados a partir das semióticas verbal e visual, englobando de aspectos prosódicos (oralidade, fala) aos visuais (desenho, gráfico), da tipografia à poesia concreta; dos símbolos gráficos ao desenho propriamente dito. Daí a ilusão de "esgotamento" do real que essas poéticas promovem.

A totalidade múltipla e multifacetada de obras ancoradas na referencialidade garantirá combinações híbridas, bricolagens e encadeamentos em relações de oposição, complementariedade, verossimilhança, compondo um tecido heterogêneo em termos de figurativização e tematização. Essa é "a realidade" oferecida por essas obras e ao mesmo tempo o seu paradoxo, na medida em que as práticas experimentais, seja o regime que for, sempre irá problematizar a crise da representação realista do mundo. Neste sentido, a ilusão da totalidade e da abrangência, inclusive de discursos contrários, acena enquanto resposta estética e ideológica. 


\section{- O regime oblíquo}

Se no regime referencial é possível reconhecer a imagem do jardim e de sua folhagem através do vidro; negá-lo significa torná-la cada vez mais distorcida, por exemplo, inserindo uma chuva torrencial na cena, capaz de transformar a folhagem atrás do vidro num verde e derretido borrão. Poéticas oblíquas irão promover um processo de dissociação entre os temas e figuras da narrativa e as imagens do mundo, criando um efeito de deformação do real, em geral progressivo, mas não necessariamente.

Elas irão instaurar a dúvida em relação a diversos aspectos da referencialidade construídos no discurso poético. São narrativas que permitem que seus protagonistas acordem transformados em insetos, que narizes caminhem em busca de seus rostos, que alferes desapareçam sem uniforme frente ao espelho. Sob o signo da obliquidade, a figurativização sofre perturbações que vão desde a indefinição de contornos ao delírio figurativo propriamente dito. Essas poéticas irão se ancorar no sentimento de estranhamento, desmanche do real, apagamento dos contornos, problematizando a verdade e a mentira, o real e a ficção. "O que está acontecendo?", pergunta-se o enunciatário dessas obras, em meio ao aceno da ilogicidade. É assim, por exemplo, que caminhamos pelo cenário titubeante de PanAmérica, sem saber onde os acontecimentos se passam. Em algum set de filmagem de Hollywood? No sonho do protagonista? Em uma tela de cinema?

Em geral, as experimentações guiadas pelo regime oblíquo podem ser ou não conservadoras em sua subversão do código verbal; e podem trabalhar ou não com questões relativas à enunciação. No entanto, obrigatoriamente, elas irão incidir sobre os processos de figurativização e tematização que acontecem em termos de semântica discursiva. O principal efeito de sentido dessas narrativas é o estranhamento do mundo. Nada pode ser definido ou afirmado nessas poéticas que nos ensinam a observar o extraordinário em suas mais diversificadas construções. 
Isso faz com que o enunciatário jamais descanse. Instigado e em contínua desconfiança, a ele caberá compreender o jogo proposto por essas obras. Daí o caráter cerebral dessas narrativas que demandam a coautoria ante as diversas lacunas de sentido, trabalhando com os elementos de imprevisibilidade e surpresa. Grosso modo, o regime oblíquo irá constantemente acionar o fazerinterpretativo desse enunciatário, acusando a mentira da representação realista do mundo.

Neste sentido, a obliquidade opera enquanto denúncia da impossibilidade do realismo, afirmando a arte enquanto procedimento artístico. Ora surrealistas, ora oníricas, ora grotescas, as experimentações guiadas pela obliquidade potencializam o delírio figurativo, afirmando a liberdade crítica e criativa. É nisso que consiste, por exemplo, a saturação dos signos trabalhada em PanAmérica, em que o signo DiMaggio, que nos remete ao famoso atleta do beisebol norteamericano (índice de referencialidade), é acrescido dos atributos míticos e demoníacos de um antissujeito responsável pelos aspectos disruptivos da narrativa.

Essa subversão do regime referencial incide, também, enquanto crítica sobre o real, mobilizando a hipérbole, o deboche, a sátira, o escárnio, o humor ácido enquanto instrumentos poderosos de contestação do real, além do nonsense e da lógica do absurdo que permeiam tanto as narrativas oblíquas quanto as míticas. É neste sentido que as nádegas dos Beatles serão besuntadas de óleo por Di Maggio e Carlo Ponti, na mansão do primeiro, no topo do mundo, de onde se pode avistar o encontro de dois Oceanos: o Atlântico e o Pacífico. A paisagem é surrealista, abre-se o absurdo, o impossível, o inimaginável.

Apesar disso, embora negue o regime referencial, libertando-se das amarras da construção realista, nas narrativas oblíquas o jardim permanece atrás do vidro, movendo-se por traz da opacidade, em meio à ventania, indubitavelmente presente. E é devido a esse contraste que obliquidade é possível, resultante do contínuo trânsito entre a referencialidade negada e a mítica que almeja em seu delírio. 


\section{- O regime substancial}

Se as experimentações guiadas pela obliquidade fazem da folhagem atrás do vidro um imenso borrão, sob a perspectiva da substancialidade, abre-se uma fresta neste vidro, permitindo-nos não somente vislumbrar um pedaço do jardim, como sentir o cheiro da chuva. Poéticas substanciais irão promover um processo de associação entre os temas e figuras da narrativa e as imagens do mundo, a partir de uma presença física que parece a avançar sobre o enunciatário.

Diferentemente das narrativas referenciais, cuja ilusão referencial se ajusta à realidade do mundo, as poéticas substanciais também trabalharão com o sentimento de estranhamento, mas ao contrário das oblíquas, em que os contornos do real se dissolve, nelas, o efeito de realidade é o de revelação, de descoberta, de susto ante um acontecimento capaz de suspender o tempo e o espaço narrativos.

Essa suspensão resulta da negação do regime mítico, que instaura pelo menos duas realidades, com predominância de uma sobre a outra, construída como "realidade" mais real, "verdade" mais verdadeira. Neste sentido, elas irão enunciar a artificialidade da construção poética, É o que vemos nos dois percursos narrativos do signo Glauber Rocha em Riverão Sussuarana que afirma o regime referencial negando e englobando, em enunciação reportada, a realidade mítica.

$\mathrm{Na}$ construção dessa fisicalidade, as experimentações orientadas pela substancialidade buscarão expressar a "natureza profunda" (cf.Floch, 1990) do discurso poético, radicalizando aspectos constitutivos da linguagem verbal, potencializando subversões do código verbal, dos elementos prosódicos ou visuais do discurso poético, dos processos de enunciação (actantes e sistemas de embreagem e debreagem) e figurativização etc. Também poderão promover sincretismos entre distintas semióticas; e toda sorte de experimentações ancoradas na construção da "tridimensionalidade" tanto das figuras articuladas ao longo da narrativa, quanto desse enunciador sempre "a um passo" do enunciatário, ou no caso de Glauber, a um palmo com seu megafone. 
O enunciatário das narrativas substanciais, por sua vez, passará a ser compreendido não apenas como "sujeito interpretativo" de uma narrativa cerebral, mas sim um sujeito estésico e somático de uma narrativa sensorial que o convoca, permanentemente, a sentir a presença física desse enunciador, ao longo das sucessivas correlações entre o plano de conteúdo e o de expressão dessas narrativas.

Neste sentido o regime substancial traz sua contribuição à utopia revolucionária do experimentalismo praticado pelas obras do nosso corpus que buscaram "sair do gueto" e participar da "festa" revolucionária do seu tempo, reivindicando para a Literatura, uma arte predominantemente verbal, o corpo-acorpo das artes performáticas, naquele período, na dianteira da resistência à ditadura.

\section{- O regime mítico}

O linguista Jean-Marie Floch, ao explicitar as diferenças entre as ideologias referencial e mítica no discurso publicitário, salientava que na Literatura, a ideologia referencial se manifesta em obras onde a ação ou a situação vivida acontecem em uma realidade composta por figuras do mundo real. Nestes regimes, os personagens são apresentados como "bancos de situação e de ação", e nelas o mundo já está dado. Já na literatura mítica, pelo contrário, os personagens não são dados, mas sim construídos ao longo dos acontecimentos (Floch, 1990, p. 202-203). Dentro dessa concepção, todas as narrativas experimentais, quando relacionadas com outras narrativas não experimentais, podem ser classificadas como míticas.

Guiadas pela imprevisibilidade e por uma lógica interna que determina sua construção semântica, nelas, os personagens e cenários somente são definidos a partir do desenrolar dos acontecimentos, conforme a trama se desenvolve. Contudo, quando aplicamos o método de Floch apenas ao universo das narrativas experimentais - o que fizemos ao longo desse trabalho - podemos observar a predominância de um desses regimes de construção semiótica. Daí 
a obliquidade em PanAmérica, a referencialidade em Zero, a substancialidade em Riverão Sussuarana e enquanto exemplo de narrativa mítica e experimental podemos citar Grande Sertão: Veredas, de Guimarães Rosa, sintetizado pela escritora Noemi Jaffe em "Grande Sertão: Veredas nunca termina" (FSP, 15.05.2016), da seguinte forma:

Grande Sertão: Veredas" é a epopéia de um jagunço, Riobaldo, atravessando o sertão mineiro para combater seu maior inimigo, Hermógenes; seu pacto com o diabo; seu amor por Diadorim. É também uma epopéia da língua portuguesa, que nos transforma em heróis épicos e trágicos de uma outra aventura: a do espanto com uma língua que é nossa, mas que é também desconhecida (ibidem).

Exemplo de regime mítico, Grande Sertão: Veredas trabalha a mítica sertaneja, inserindo-se no panteão dos clássicos da literatura, ao lado de Os Sertões de Euclides da Cunha, outro monumento da mítica sertaneja. E o faz construindo uma linguagem reinventada, a partir de procedimentos experimentais que subvertem o código verbal, na construção de uma língua particular, com sintaxe própria, ortografia e vocabulário orientados pela oralidade, entre outras experimentações - a começar pelo travessão que inicia a obra -, em uma estrutura revestida por temas e figuras desse universo sertanejo, reatualizado pela imaginação poderosa de Rosa, sob uma lógica que inexiste no mundo, ela só pode ser encontrada dentro desta obra.

Retomando a alegoria de Ortega y Gasset, o vidro escritural do regime mítico seria não mais um vidro com um jardim por trás, mas sim o espelho mágico capaz de nos puxar para dentro, tal qual o espelho mágico de Alice. Não é de se estranhar que esse efeito mítico de construção do real seja predominante em textos de ficção científica ou aventura, bem como nos textos épicos e outras narrativas que constroem sua realidade conforme o desenrolar da trama. Narrativas míticas são aquelas que constroem suas figuras e temas de modo desarticulado com as "imagens do mundo", ancorando-se suas figuras em um universo particular, dotado de leis e lógica próprias. 
Neste sentido, o contrato de veridicção entre enunciador e enunciatário dependerá, nessas obras, da predisposição desse enunciatário em aceitar o "jogo" do enunciador; afinal, compreender essas narrativas diz respeito a experimentá-las, permitindo-se um dissociar das imagens do mundo, efeito imediato que elas promovem, lançando-nos em outro universo, como se pudessem nos sequestrar da realidade.

Poéticas míticas e experimentais buscarão novas combinações entre suas isotopias figurativas e temáticas. Elas irão incidir sobre o código verbal, articular distintas linguagens, propor vocabulários próprios, correlacionar seus planos de expressão e de conteúdo, que se alimentam e retroalimentam semanticamente. Na construção de sua realidade, até mesmo o texto se recusará a ser referencial, como vemos no clássico rosiano. Ao construir seu vocábulo, Rosa desestabiliza o código verbal, desautomatizando nossa leitura. Devagar, os leitores de Grande Sertão aprendem a observar a formação das palavras e das paisagens, e a ouvir a prosódia de uma linguagem que nos bota em dúvida: sabemos que é mentira - ninguém fala desse jeito -, mas não duvidamos da realidade apresentada, afinal, ela constrói as estruturas que sustentam sua mítica. Daí o uso de arquétipos universais, como o pacto com o Diabo por exemplo.

Narrativas experimentais podem se manifestar em regimes referenciais potencializando os efeitos de realidade, apresentados como provas daquilo que é dito. Podem se manifestar em regimes oblíquos, construindo o sentimento de dúvida frente ao real, o inexplicável, o extraordinário; ou em regimes substanciais, a partir da revelação de ordem sensorial, arrancando os véus de dada ilusão de realidade. E podem, também, almejar a máxima liberdade de composição constituindo suas próprias leis. Independente do regime que for, tudo dependerá do contrato de fidúcia entre enunciador e enunciatário, que no caso das obras do nosso corpus, se instaura pelas articulações veridictórias do modelo de realidade ofertado ao enunciatário.

Como destaca Maria de Lourdes Baldan no artigo "Veridiç̧ão: um problema de verdade" (1988), o contrato veridictório se estabelece segundo o ser e o parecer do objeto. Todo discurso possui pelo menos dois discursos em 
seu interior, um é o texto figurativo que "conta a estória, o conjunto de acontecimentos que se supõem operados pelo fazer do sujeito", e pelo qual teremos um saber ao modo do parecer e do não parecer; e outro, o texto veridictório, metatexto que "parafraseia o relato figurativo declarando ao modo do ser (e/ou do não ser) o mesmo saber que aquele produzira ao modo do parecer", esse texto é vocalizado por meio de um relato interpretativo. (Baldan, 1988: página). A veridicção se situa na articulação dos textos figurativo e veridictório que nos permite identificar se um discurso é uma verdade, uma mentira, uma falsidade ou um segredo, conforme o modelo abaixo:

Figura 17- Articulações Veridictórias sobre o Quadrado Semiótico

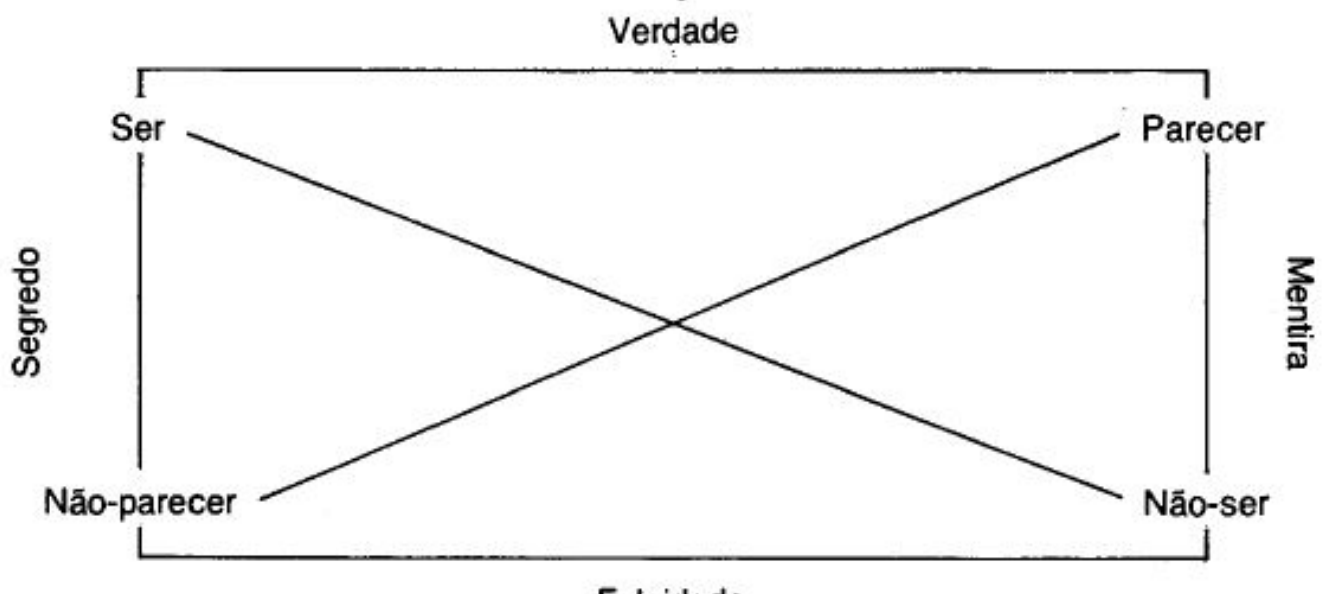

Falsidade

Fonte: Baldan, M.L. In: "Veridicção: um problema de verdade” (1988)

Verdade é aquilo que é e que parece ser isso que é (produção do saber autêntico)

Falsidade é "aquilo que nem é (o que é) e nem parece ser (isso que é)" (produção do não-saber).

Mentira é "aquilo que parece ser (o que é) mas não é" (produção de simulação do saber - parecer saber).

Segredo é "aquilo que é (o que é) mas não parece ser" (produção de dissimulação do saber - parecer não-saber).

(Baldan, 1988: data) 
A partir da concomitância entre os dois eixos, o de Floch que investiga os regimes de realidade, e o das modalizações do ser vs. parecer acima, podemos afirmar que:

- Em narrativas experimentais com predominância do regime referencial, o enunciatário será manipulado em seu fazer interpretativo pelo efeito de sentido de "verdade" das imagens do mundo que compõem o revestimento figurativo e temático dessas obras, e que "são o que são" e "parecem ser o que são", a experimentação tenderá a potencializar no enunciatário a sensação de verdade diante dessas imagens. O contrário ocorre com as narrativas experimentais em que o regime mítico predomina. Nelas, o fazer interpretativo será manipulado pela aceitação da falsidade, na medida em que as imagens do mundo irão afirmar sua estranheza: elas não são e nem parece ser (isso que é).

- Em narrativas experimentais com predominância do regime oblíquo, o fazer interpretativo do enunciatário será manipulado por um estranhamento diante do real que levará à construção da mentira e da desconfiança sobre a realidade apresentada. Nessas narrativas, as imagens do mundo são perturbadas pelo delírio figurativo explicitando que o que parece ser (o que é) não é. O contrário ocorre nas experimentais com predominância do regime substancial, onde o fazer interpretativo será manipulado pela revelação de um segredo: o que é mas não parecia ser devido a uma presença física, construída na linguagem verbal, capaz de instaurar uma realidade mais próxima junto ao enunciatário.

Todos os romances irão revestir figurativa e tematicamente seus discursos a partir desses quatro regimes de realidade - referencial, mítico, oblíquo e substancial -, com figuras articuladas ou não com as imagens do mundo. Quando adotamos o método de Floch em um corpus mais amplo, estabelecendo relações entre obras experimentais e não experimentais, nossa tendência é a de classificar as experimentais como pertencentes ao regime mítico, afinal, elas se estruturam a partir de lógicas particulares. 
Contudo, ao fixarmos nosso olhar sobre as narrativas essencialmente experimentais, nós conseguimos identificar a presença desses regimes de realidade, e não apenas do regime mítico, possibilitando comparações entre obras de um mesmo tipo ou de regimes diferentes. Ao identificarmos esses regimes de realidade, e não apenas o regime mítico, inerente a qualquer narrativa experimental, podemos estabelecer:

- Comparações entre obras de um mesmo tipo ou de regimes diferentes, o que evita equívocos crassos, como a cobrança de uma lógica em meio à surrealidade crescente de PanAmérica;

- Apreciar e observar os modos de construção da referencialidade, da mítica, da substancialidade e da obliquidade nos textos experimentais, estabelecendo parâmetros neste sentido;

- Observação sincrônica dos experimentalismos que trazem abordagens inovadoras. No caso dos romances experimentais, os efeitos de realidade são intensificados, o que nos permite observar a construção figurativa e discursiva, cerne da criação literária porque dizem respeito ao modo como significamos nossa experiência com a realidade, seja ela verdade, mentira, falsidade ou segredo. 


\section{Conclusão: A memória em disputa}

O presente trabalho começa em um país e termina em outro.

Após o golpe em 2016, o Brasil de Dilma Rousseff, ex-ministra de Minas e Energia e da Casa Civil, combatente da resistência à ditadura, foi sucedido pelo Brasil de Jair Bolsonaro, ex-deputado federal, defensor aguerrido da ditadura militar e dos criminosos de lesa pátria daquele período. Uma mudança que nos faz atestar a atualidade do nosso corpus, e a permanência da cultura autoritária em nosso país.

Em menos de quatro anos, Bolsonaro saltou do ostracismo político à presidência da República, em reviravolta iniciada na sessão de impeachment da Câmara dos Deputados, em agosto de 2016, quando dedicou seu voto a "Carlos Alberto Brilhante Ustra, o pavor de Dilma Rousseff" (OESP,08.08.2016). Com essa declaração, que não encontrou nenhuma represália, o então parlamentar angariou popularidade, capitalizando o antipetismo, reatualização do anticomunismo de outrora, disseminado pelas forças articuladoras do Golpe contra o governo petista.

Interessante observar que, oito anos antes, a então ministra do Governo Lula, Dilma Rousseff angariava popularidade também em episódio relacionado à ditadura. Convocada à sessão do Senado, em 7 de maio de 2008, ela respondia, com a autoridade da experiência, à provocação do senador José Agripino Maia (DEM-RN), que a acusava de ter mentido para autoridades brasileiras no passado:

Eu tinha 19 anos, fiquei três anos na cadeia e fui barbaramente torturada, senador. E qualquer pessoa que ousar dizer a verdade para os seus interrogadores, compromete a vida dos seus iguais e entrega pessoas para serem mortas. Eu me orgulho muito de ter mentido senador, porque mentir na tortura não é fácil. Agora, na democracia se fala a verdade, diante da tortura, quem tem coragem, dignidade, fala mentira. E isso e isso, senador, faz parte e integra a minha biografia, que eu tenho imenso orgulho, e eu não estou falando de heróis. 
Feliz do povo que não tem heróis desse tipo, senador, porque aguentar a tortura é algo dificílimo, porque todos nós somos muito frágeis, todos nós. Nós somos humanos, temos dor, e a sedução, a tentação de falar o que ocorreu e dizer a verdade é muito grande senador, a dor é insuportável, o senhor não imagina quanto é insuportável. Então, eu me orgulho de ter mentido, eu me orgulho imensamente de ter mentido, porque eu salvei companheiros, da mesma tortura e da morte.

Não tenho nenhum compromisso com a ditadura em termos de dizer a verdade. Eu estava num campo e eles estavam noutro e o que estava em questão era a minha vida e a de meus companheiros. E esse país, que transitou por tudo isso que transitou, que construiu a democracia, que permite que hoje eu esteja aqui, que permite que eu fale com os senhores, não tem a menor similaridade, esse diálogo aqui é o diálogo democrático. A oposição pode me fazer perguntas, eu vou poder responder, nós estamos em igualdade de condições humanas, materiais.

O que mata na ditadura é que não há espaço para a verdade porque não há espaço para a vida, senador. Porque algumas verdades, até as mais banais, podem conduzir à morte. É só errarem a mão no seu interrogatório. $\mathrm{E}$ eu acredito, senador, que nós estávamos em momentos diversos da nossa vida em 70 . Eu asseguro ao senhor, eu tinha entre 19 e 21 anos e, de fato, eu combati a ditadura militar, e disso eu tenho imenso orgulho (Rousseff, Senado Federal, 07.05.2008) ${ }^{39}$.

É justamente esse orgulho, essa afirmação da liberdade frente a opressão do Estado, essa verdade histórica, tão bem expressa na fala acima, que a extrema-direita, instalada no Palácio do Planalto, procura combater. Ora criminalizando, ora difamando todo o repertório constituído sobre aquele período, inclusive, as mais de seis mil páginas do relatório da Comissão Nacional da Verdade, instituída durante o governo Dilma.

Neste sentido, a literatura (e as artes em geral) atua como guardiã - e desde a primeira hora do Golpe de 1964 - desse repertório sensível e cognitivo sobre a experiência de mais de duas décadas de autoritarismo de Estado.

\footnotetext{
${ }^{39}$ Audiência pública na Comissão de Serviços de Infraestrutura para debater o andamento das obras do Programa de Aceleração do Crescimento - PAC, em 7 de maio de 2008. O trecho do depoimento pode ser conferido no YouTube em <

https://www.youtube.com/watch?v=Tiyezo1fLRs > Acesso em 05.11.2019
} 
Impulsionadas por uma revolução cultural e comportamental, elas irão afirmar a liberdade em todos os níveis, sobretudo, em seu plano de expressão. Territórios de investigação formal e de defesa política da liberdade em contexto de opressão, essas obras irão se contrapor ao silenciamento imposto, deglutindo seu contexto social, político, cultural e econômico, e o devolvendo sob a forma de avalanches de ideias e perspectivas.

Agrippino de Paula, em sua PanAmérica, de 1967, irá organizar esse material diverso - os discursos de poder e contrapoder e as paixões que os relacionam - aos moldes da montagem cinematográfica, em crescente ilogicidade, expressando as sensações frente a um mundo que parece ter perdido não apenas o seu contorno, mas a sua humanidade. Loyola Brandão construirá uma instalação verbivocovisual, combinando toda sorte de estímulos verbais, orais e visuais, na construção de uma ilusão "total" de realidade, como se nada pudesse escapar desse enunciador. Glauber Rocha, por sua vez, a partir de um megafone verbal, irá atordoar seu leitor, construindo sua presença a partir de um fluxo de pensamentos, ora mais veloz, ora menos, aos moldes de um grande rio de experimentações verbais.

Em suas unidades cênicas, pequenos pedaços de um grande mosaico, essas obras reverberam a opressão do Estado, o discurso oficial, o crescimento da desigualdade social, as vanguardas daquele momento, o discurso da tradição. E estabelecem conexões entre si, englobando outros discursos (ficcionais ou não) por meio da intertextualidade e de outras linguagens. Conexões que condensam o repertório (temporal e geográfico) daquele período, nos permitindo, meio século depois, acessar uma verdade histórica constantemente atacada. Elas imprimem, portanto, no tecido cultural que nos alimenta, um forte alerta contra o autoritarismo. E essa é a primeira didática dessas obras, a verdade histórica que carregam. 


\title{
Fruição experimental
}

A segunda é a didática do experimento, tão bem ilustrada pela resposta de Augusto de Campos em entrevista a Eduardo Sterzi (Teoria Literária Unicamp) e ao poeta Tarso de Melo, escritores e editores da revista CACTO: poesia \& crítica (2002). Questionado sobre a articulação da "crítica da linguagem, que the é fundamental, com o protesto social" em sua obra, Campos afirma:

\begin{abstract}
"Greve" é o poeta em greve de Mallarmé e é a própria greve (o poema é de 1961, um dos nossos períodos políticos mais conturbados) e apareceu na antologia Noigandres 5 (1962) na revista Invenção 3 (1962), o número vermelho. Só estranho é que os nossos críticos de tendência sociologizante nunca tenham sido capazes de detectar esses traços na minha poesia. Não me considero um poeta político (no sentido em que um Maiakóvski o foi), mas pela minha própria condição de poeta, "à margem da margem" (na expressão de Pignatari), ou "à esquerda da esquerda" (na de lessiênin), sempre me identifiquei com os socialmente marginalizados. E em certos momentos, como em 1962-1965, quando se aguçou tragicamente o debate político, com o golpe militar, não deixei de manifestar-me crítico poeticamente. A diferença entre o meu trabalho, bem como os de Haroldo, Décio, José Lino, Ronaldo, daquela época, e o dos que rezavam pela cartilha do Centro Popular de Cultura, é que jamais abdicamos da linguagem experimental, acreditando, como acreditávamos, com Maiakóvski, que "não há arte revolucionária sem forma revolucionária". (Sterzi, Melo, 2002, p.186-187, grifos nossos)
\end{abstract}

É sob essa perspectiva revolucionária da arte; e dessa combinação de duas didáticas - a que nos traz a verdade histórica e a que nos ensina a fruição da linguagem pelo experimento - que essas obras nos conduzem aos lugares não-comuns e imprevisíveis do texto. Desvinculada de qualquer pretensão de aconselhar, tal como os marujos de Walter Benjamin, nos tempos em que ainda era possível aconselhar com histórias, as narrativas experimentais pretendem inserir o enunciatário no cerne da experiência.

Poéticas da liberdade, elas promovem a quebra do horizonte de expectativas (Maingueneau, 1996), o choque no receptor (Chklovsky, 1976), a 
fratura entre leitor e linguagem (Barthes, 2008) e por isso é impossível sintetizálas sem mencionar o seu artesanato. Nisso consiste a didática do experimentalismo. Qualquer comentário sobre PanAmérica passa pela lembrança de seu delírio figurativo, o mesmo ocorre em relação ao delírio enunciativo em Riverão Sussuarana. As sucessivas descontinuidades (sintáticas ou semânticas) promovidas pela literatura do experimento reorganizam as expectativas do enunciatário, impedindo uma leitura ingênua dos processos constitutivos das obras: eles saltam diante dos nossos olhos.

Nessas obras, a liberdade de criação do enunciador está intrinsicamente relacionada à liberdade de interpretação do enunciatário. Enquanto o fazer experimental se expressa em termos de criação e reflexão sobre o exercício criador (cf. Mello e Castro), o fazer interpretativo passa pela adesão ao estranhamento e à apreensão do jogo enunciativo. Obras experimentais promovem estranhamento porque instauram, inevitavelmente, o texto não experimental enquanto "outro discursivo" (Maingueneau, 2008), com quem dialogam. Narrativas de fruição (Barthes, 2008), esse estranhamento promoverá o desconforto entre leitor e linguagem, sobretudo quando as experimentações incidirem sobre o código verbal. É o caso, por exemplo, de Grande Sertão: Veredas que imbrica as linguagens oral e verbal na constituição de um vocabulário prosódico, capaz de sustentar a mítica sertaneja trabalhada, em tamanho esplendor, no plano de conteúdo.

Disso decorre a desautomatização do ato de leitura. É preciso atenção para compreender suas subversões, e permanecer na narrativa ao longo de sucessivas descontinuidades em relação à norma, como as experimentações sincréticas que combinam linguagens e técnicas de suportes distintos (instalação, colagem, pintura, cinema, canto, teatro etc.). Daí a correlação entre seus planos de conteúdo e de expressão, permitindo-nos assistir ao "cinema" projetado em PanAmérica; manusear o caleidoscópio verbivocovisual de Zero; e sentir a respiração prosódica de Glauber, por todos os lados e em seus vários "eus" enunciativos.

Obras experimentais evocam os efeitos de sentido do imprevisto, da justaposição, do happening, ou seja, de uma escrita muito mais horizontal que 
vertical, mais dissonante que padronizada, mais ramificada do que enraizada. Suas unidades cênicas se articulam a partir de infinitas ramificações, encadeando uma cena a outra, pelas combinações de isotopias figurativas e temáticas, em processo de soma contínua e inesgotável. É essa lógica, descentralizada e horizontal - muito mais próxima do mundo virtual e em rede que do mundo analógico -, que as anima.

Caracterizadas pela quebra da linearidade, essas narrativas são constituídas em sucessivas descontinuidades, mais ou menos bruscas. Elas nos obrigam à leitura não-linear, abrindo nossa percepção para diferentes formas de organização de suas unidades cênicas. Nelas, podemos observar a construção do discurso literário, porque seu arcabouço é explicitado. Daí o interesse nesse tipo de arte pelos que pensam e praticam a criação artística, afinal, ler o experimental é mergulhar nas possibilidades de expressão de várias linguagens, em um jogo de vivência e reflexão crítica sobre a experiência da escritura. E, neste sentido, a profecia de Ortega y Gasset, de que as vanguardas se constituiriam uma "arte de artistas" parece nos assombrar. A única forma de publicizar essas obras é falar sobre elas.

\section{Desobediência civil e criadora}

A desobediência civil e criadora dessas narrativas nos permite, cinquenta anos depois, experimentar a vertigem daquele momento, refletindo sobre questões que ainda (e muito) nos dizem respeito.

São obras que lidam com a polarização ideológica entre direita e esquerda, resultante do alinhamento (à fórceps) da sociedade brasileira, e demais povos da América Latina, aos Estados Unidos no contexto da Guerra Fria. Nessas narrativas, as polarizações e o conjunto de valores em disputa naquele período foram organizados aos moldes da proposta tropicalista: a partir da justaposição dos contrários, em crescente contraste e complexificação das nuances ideológicas, morais, sociais. 
Em PanAmérica (1967), por exemplo, o imperialismo norte-americano não será simplesmente apresentado como algo ruim ou bom, pertencente a esta ou aquela esfera da luta política; ele será exposto em diferentes nuances, permitindo-nos identificar tanto o deboche dos poderosos, ridicularizados de modo implacável por Agrippino de Paula; como a sedução do consumo e o prazer promovidos pelos objetos do capitalismo; o fascínio pelos mitos hollywoodianos; em suma, as ilusões da ideologia consumista e individualista na sociedade de massas do pós-Guerra.

Caberá ao enunciatário, a quem se destina os mais variados discursos, preencher as lacunas sugeridas pela intertextualidade e pelos lapsos de sentido originados pelo estilhaçamento da ordem linear e não raro da lógica. E este enunciatário, o leitor de ontem e o de hoje, deverá fazê-lo a partir do seu repertório cultural, histórico e político prévio. Em Riverão Sussuarana, por exemplo, vários personagens (e o próprio Sertão) são extraídos de obras do próprio Glauber Rocha, de Guimarães Rosa ou da mítica sertaneja, em diálogo contínuo de diferentes discursos, ficcionais ou não.

Daí a vertigem polifônica ocasionada pelo jogo transtextual, em fluxo permanente de referências que vão desde citações diretas a paródias e outros modos de intertextualidades. Polifonia construída em torno da oposição semântica opressão vs. liberdade do nível fundamental do percurso gerativo de sentido. Partindo dessa tensão, culturalmente definidora do que somos enquanto Nação, cada uma dessas obras explicita o tensionamento fundante das nossas relações sociais. No romance de Loyola Brandão, por exemplo, as modalizações do sujeito, constantemente ameaçado em seu poder-fazer (liberdade) e seu poder-não-fazer (independência), expressam a contradição do trabalhador informal no Brasil, 41,6\% dos trabalhadores brasileiros em 2019 (39,3 milhões de pessoas) segundo o IBGE ${ }^{40}$.

As três narrativas também trazem em seu plano de expressão forte sentimento de ruptura, decorrentes de diversas formas de fragmentação

\footnotetext{
${ }^{40}$ Dados veiculados pela Agência Brasil, em 12 Nov 2020:

https://agenciabrasil.ebc.com.br/economia/noticia/2020-11/ibge-informalidade-atinge-416-dos-

trabalhadores-no-pais-em-2019
} 
textual, evocando rupturas históricas, políticas e comportamentais. Seja a quebra do pacto democrático e os efeitos brutais do golpe; seja o grito civilizatório em todas as partes do mundo, englobando questões de ordem comportamental, de direitos civis e humanos, de soberania nacional, sem os quais seria impossível pensar os avanços que, ao fim e ao cabo, tivemos ao longo dos últimos 40 anos.

Tanto em termos de criação, quanto de fruição literária, a forma experimental irá se relacionar ao incerto, ao não-convencional, ao fora do script e, principalmente, ao devir resultante da experiência de desautomatização da linguagem. Investigação e experimento, ela consegue abalar nossas certezas em relação ao literário, afirmando a potência criativa e criadora da linguagem verbal. 


\section{Referências}

ANDRADE, Mário de. Obras imaturas. Rio de Janeiro: Agir, 2009.

ANDRADE. Mário de. Aspectos da literatura brasileira. São Paulo: Martins Fontes, 1943.

ANDRADE. Pauliceia Desvairada. Iba Mendes (Org.). Projeto Livro Livre (edição digital): São Paulo, 2016. Disponível em: < http://sanderlei.com.br/PDF/Mario-de-Andrade/Mario-de-Andrade-Pauliceia-

Desvairada.pdf > Acesso em 20 mar. 2018.

ANDRADE, Oswald de. Serafim Ponte Grande. Rio de Janeiro: Globo, 2007.

ANDRADE. Manifesto da Poesia Pau Brasil. Universidade Federal do Rio Grande do Sul: Porto Alegre, online. Disponível em: < http://www.ufrgs.br/cdrom/oandrade/oandrade.pdf > Acesso em: 13 abr. 2018.

ARANTES, Otília B. Fiori. Depois das vanguardas. Arte em Revista. São Paulo: Centro de Estudos de Arte Contemporânea, ano 5, n.7, ago,1983.

ASSIS, Machado. Memorias Póstumas de Brás Cubas. Rio de Janeiro: Globo, 2008.

AUMONT, Jacques; MARIE, Michel. Dicionário teórico e crítico de cinema. Campinas: Papirus, 2003.

BALDAN, Maria de Lourdes O. G. Veridiç̧ão: um problema de verdade. ALFA: Revista de Linguística. São Paulo, v.32, 1988.

BAKHTIN, Mikhail. A Cultura Popular na Idade Média e no Renascimento. São Paulo: Hucitec, 2002.

BANHAM, Peter Reyner. Veículos do Desejo, 1955. Tradução comentada de Luiz Florence. Revista Veneza, 25 fev. 2001. Disponível em: < http://revistaveneza.wordpress.com/2011/02/25/veiculos-do-desejo/ >. Acesso em: 10 jun. de 2014.

BARROS, Diana. Teoria do Discurso. Fundamentos Semióticos. São Paulo: Humanitas, 2002.

BARROS, Diana. Teoria Semiótica do Texto. São Paulo: Ed. Ática, 2005.

BARTHES, Roland. Aula. São Paulo: Cultrix, 2013.

BARTHES. O Prazer do Texto. Perspectiva: São Paulo, 2008 
BARTHES. Mitologias. Rio de Janeiro: Bertrand Brasil, 2001.

BARTHES. Elementos de semiologia. Cultrix: São Paulo, 1971.

BARTHES. O Rumor da Língua. Martins Fontes: São Paulo, 2004.

BERTRAND, Denis. Caminhos da Semiótica Literária. São Paulo, Bauru: EDUSC, 2003.

BEAUVAIS, Yann. A gente saía de manhã sem ter ideia. Lugar Comum. Rio de Janeiro: LABTeC/ESS/UFRJ, n.28, maio-ago., 2009. Disponível em: < http://uninomade.net/wp-

content/files mf/111102120410lugarcomum 28 completa.pdf $>$. Acesso em: 10 jun. 2014.

BENTO, Carlos Henrique. Pan e latina América: o delírio épico de José Agrippino de Paula. Juiz de Fora: IpotesI, v.12, n.1, Jan./Jul., 2008.

BRANDÃO, Ignácio de Loyola. Zero. 13a .ed. São Paulo: Global, 2012.

CAMPOS, Haroldo de. A arte no horizonte do provável. São Paulo: Perspectiva, 1969.

CAMPO, Augusto de. Revista CACTO: poesia \& crítica, v.1. São Paulo: Alpharrabio, 2002, p. $185-195$.

CARDOSO, Maurício. Uma nova estética, um novo cinema. Dossiê Glauber Rocha. Revista CULT, São Paulo, n. 155, Mar, 2011. Disponível em: < https://revistacult.uol.com.br/home/uma-nova-estetica-e-um-novo-cinema/ > / < https://www.cultloja.com.br/produto/dossie-glauber-rocha-cult-155/>

CASTANHEIRA, Daniel Fernandes. O lugar público de Agrippino. Trânsito e espacialidade na cidade-qualquer. 2009. 90f. Dissertação (Mestrado em Letras) - Pontifícia Universidade Católica do Rio de Janeiro, Rio de Janeiro. Disponível em: < $\quad$ https://www.maxwell.vrac.pucrio.br/colecao.php?strSecao=resultado\&nrSeq=14450@1 > Acesso em: 10 jun. 2014.

CHAUÍ, Marilena. Manifestações ideológicas do autoritarismo brasileiro. Belo Horizonte: Autêntica, FPA, 2013.

CHAURAUDEAU, Patrick; MAINGUENEAU, Dominique. Dicionário de Análise do Discurso. Contexto: São Paulo, 2016.

COMISSÃO NACIONAL DA VERDADE (CNV). Relatório da Comissão Nacional da Verdade. Governo Federal: Brasília, 2014. Disponível em: < http://cnv.memoriasreveladas.gov.br/images/pdf/relatorio/volume_1_digital.pdf > Acesso em: 20 mai.2018.

CORREA, José Celso Martinez. Entrevista concedida a José Arrabal. Rio de Janeiro: Revista Civilização Brasileira, v.20, 1979. 
CORREA, José Celso Martinez. O Rei da Vela: Manifesto do Oficina. O Rei da Vela. São Paulo, 1967. Programa do espetáculo. Disponível em: <

http://tropicalia.com.br/leituras-complementares/o-rei-da-vela-manifestooficina\#sthash.5sonlURw.dpuf. > Acesso em: 10 jun. de 2018.

COURTÉS, J; GREIMAS, A.J. Dicionário de Semiótica. São Paulo: Contexto, 2016.

CUNHA, Juliana Andrade. Sujeito e cultura na virada dos anos 60: contribuições para o debate a partir de PanAmérica epopéia de José Agrippino de Paula. 2007. 105f. Dissertação (Mestrado em Comunicação), Universidade Federal

da

Bahia,

Salvador.

DE MORAES, Felipe Augusto. A arte-soma de José Agrippino de Paula. 2011. 164f. Dissertação (Mestrado em Comunicação) - Universidade de São Paulo, São Paulo. Disponível em: < http://www.teses.usp.br/teses/disponiveis/27/27139/tde-04082009-222835/ptbr.php > Acesso em: 10 jun. 2018.

DE PAULA, José Agrippino de. PanAmérica. $3^{a}$ ed. Editora Papagaio: São Paulo, 2001.

DE PAULA, José Agrippino de. Lugar Público. Editora Papagaio: São Paulo, 2004.

DA FONSECA, Jair Tadeu. Guimarães Rocha (ou Glauber Rosa). outra travessia, Florianópolis, n. 7, p. 21-28, jan. 2008. ISSN 2176-8552. Disponível em: $\quad<$ https://periodicos.ufsc.br/index.php/Outra/article/view/11973/11237>. Acesso em: 14 fev. 2020. doi:https://doi.org/10.5007/\%x.

OXFFORD. Dicionário de Arte Moderna e Contemporânea. Oxford, Londres, versão online, 2015. Disponível em <

http://www.oxfordreference.com/view/10.1093/oi/authority.20110803095805811 $>$ Acesso em 20 fev. 2018.

DOWBOR, Ladislau. A Formação do Terceiro Mundo. 15 a edição revista. São Paulo: Editora Brasiliense, 1995. Disponível em: < http://dowbor.org/blog/wpcontent/uploads/2012/06/2002-ftm-revis\%C3\%A3o-nova.doc > Acesso em: 10 fev. 2018.

DOWBOR, Ladislau. Formação do Capitalismo no Brasil - Ensaio Teórico. São Paulo: Ed. Brasiliense, 2010. Disponível em: < http://dowbor.org/blog/wpcontent/uploads/2012/06/formcap1.rtf > Acesso em: 19 mar. 2018.

ELIADE, Mircea. Mito e Realidade. São Paulo: Perspectiva, 1972.

FARINACCIO, Pascoal. A questão da representação e o romance brasileiro contemporâneo. 2004. 305 f. Tese (Doutorado em Teoria e História Literária) - 
Instituto de Estudos da Linguagem da Universidade Estadual de Campinas, Campinas, 2004.

FAVARETTO, Celso. Tropicália, alegoria, alegria. Ateliê Editorial: Cotia (SP), 2007.

FIGUEIREDO, Eurídice. A literatura como arquivo da ditadura brasileira. Rio de Janeiro: 7 Letras, 2017.

FIORIN, José Luiz. As astúcias da enunciação. São Paulo: Ática, 1996.

FIORIN, José Luiz. Linguagem e ideologia. São Paulo: Ática, 1988.

FIORIN, José Luiz. Em busca do sentido. Estudos discursivos. São Paulo: Contexto, 2008.

FLOCH, Jean-Marie. Petites mythologies de l'oeil et de l'esprit. HadèsBenjamin: Paris-Amsterdam, 1985.

FLOCH, Jean-Marie. Sémiotique, marketing et communication. PUF: Paris, 1990.

FLOCH, Jean-Marie. Semiótica, marketin y comuncacion: bajo los signos, las estrategias. Barcelona: Paidos, 1993.

FLOCH, Jean-Marie. Sémiotique plastique et langage publicitaire. Actes Semiotiques, Limoges, n.26, 1981. Disponível em: <https://www.unilim.fr/actessemiotiques $/ 6014 \&$ file=1 $>$ Acesso em: 06 set 2020.

FLOCH, Jean-Marie. Des couleurs du monde au discours poétique. Actes Semiotiques, Limoges, n.6, 1979. Disponível em: < https://www.unilim.fr/actessemiotiques/5879\&file=1 > Acesso em: 07 set 2019 .

FLOCH, Jean-Marie. La génération d'un espace commercial. Actes Semiotiques, Limoges, n.87, 1987. Disponível em: < https://www.unilim.fr/actessemiotiques/6138\&file=1 > Acesso em: 22 jul 2018.

FLAUZINA, Ana Luiza Pinheiro. Corpo Negro Caído no Chão: O sistema penal e o projeto genocida do Estado brasileiro. Contraponto: Rio de Janeiro, 2008.

GARCIA, Marco Aurélio; VIEIRA, Maria Alice. Rebeldes e Contestadores: 1968 - Brasil, França e Alemanha. Fundação Perseu Abramo: São Paulo, 1998.

GASPARI, Élio. A ditadura envergonhada: as ilusões armadas. São Paulo: Intrínseca, 2014.

GENETTE, Gerard. Palimpsestos: a literatura de segunda mão. Belo Horizonte: Faculdade de Letras, 2006.

GENTILLI, Pablo (org.). Golpe en Brasil - Genealogía de una farsa. Consejo Latinoamericano de Ciencias Sociales (CLACSO): Buenos Aires, 2016. 
Disponível

em:

$<$

https://www.clacso.org.ar/librerialatinoamericana/libro detalle.php?id libro=1115 > Acesso em: 20 abr. 2018.

GREEN, James; Jones, Abigal. Reinventando a história: Lincoln Gordon e as suas múltiplas versões de 1964. Revista Brasileira de História, São Paulo, v.29, n.57, Jun.2009. Disponível em: < https://www.scielo.br/pdf/rbh/v29n57/a03v2957.pdf > Acesso em: 01.10.209.

GREIMAS, Algirdas Julien. Análise Estrutural da Narrativa. Rio de Janeiro: Vozes, 2013.

GREIMAS, Algirdas Julien. Ensaios de semiótica poética. São Paulo: Cultrix, 1975.

GREIMAS, Algirdas Julien. Semântica estrutural. São Paulo: Cultrix, 1973.

GREIMAS, Algirdas Julien. Sobre o Sentido. Ensaios Semióticos. Petrópolis: Vozes, 1975.

GREIMAS, Algirdas Julien. Sobre o Sentido II. Ensaios semióticos. São Paulo: Nakin: Edusp, 2014.

GUEVARA, Ernesto Che. Mensagem aos povos do mundo através da Tricontinental. Havana, Organização de Solidariedade com os Povos de África, Ásia e América Latina, 16 abr. 1967. Disponível em: < https://www.novacultura.info/single-post/2018/06/14/Mensagem-aos-Povos-doMundo-Atraves-da-Tricontinental > Acesso em: 05 maio 2018

HJELMSLEV, Louis. Prolegômenos a uma teoria da linguagem. Perspectiva: São Paulo, 2009.

HJELMSLEV, Louis. Ensaios lingüísticos. Perspectiva: São Paulo, 1991.

HOISEL, Evelina. Supercaos: os estilhaços da cultura em PanAmérica e Nações Unidas. Civilização Brasileira: Rio de Janeiro; Fundação Cultural do Estado da Bahia: Salvador, 1980.

HOISEL, Evelina. PanAmérica: uma cartografia dos processos de globalização nos anos de 1960. IN: Recôncavo - Revista do Centro de Artes, Humanidades e Letras. Bahia, Universidade Federal da Bahia, vol. 2 (1), 2008. HOLLANDA, Heloisa Buarque de. Impressões de viagem: CPC, vanguarda e desbunde: 1960 / 70. Aeroplano: Rio de Janeiro, 2004.

JAKOBSON, Roman. Linguística e Comunicação. São Paulo: Cultrix, 2010.

JAMESON, Fredric. Posmodernismo: El pós-modernismo o la lógica cultural del capitalismo avanzado. Madrid: Paidós Studio, 2011.

JAMESON, Fredric. A virada cultural: reflexões sobre o pós-moderno. Rio de Janeiro: Civilização Brasileira, 2006. 
LÉVI-STRAUSS, Claude. A estrutura dos Mitos. Antropologia Estrutural. São Paulo: UBU Editora, 2017, p. 205-231

LIMA, Venício. Mídia, Teoria e Política. São Paulo: Fundação Perseu Abramo, 2001.

KERŠYTÉ, Nijolé. L'idéologie réactualisée dans la sémiotique de Greimas. Actes Semiotiques, Limoges, n.123, 2020 [En ligne]. Disponível em: < https://www.unilim.fr/actes-semiotiques/6505 > Acesso em: 02 nov 2020.

LYOTARD, Jean-François. O pós-moderno. Rio de Janeiro: José Olympio, 1986.

MADAZZIO, Irlainy Regina. O Voo da Borboleta: A obra cênica de José Agrippino de Paula e Maria Esther Stockler. 2006. 103f. Dissertação (Mestrado em Artes Cênicas) - Universidade de São Paulo, São Paulo. Disponível em: < http://www.teses.usp.br/teses/disponiveis/27/27139/tde04082009-222835/pt-br.php >

MAINGUENEAU, Dominique. Gênese dos Discursos. São Paulo: Parábola Editorial, 2008.

MAINGUENEAU, Dominique. Pragmática para o discurso literário. Coleção Leitura e Crítica. São Paulo: Martins Fontes, 1996.

MAINGUENEAU, Dominique. O contexto da obra literária: enunciação, escritor e sociedade. Coleção Leitura e Crítica. $2^{a}$ ed. São Paulo: Martins Fontes, 2001.

MANSO, Bruno Paes Manso. A República das Milícias: dos esquadrões da morte à era Bolsonaro. São Paulo: Todavia, 2020.

MELO E CASTRO, Ernesto de. O Fim Visual do Século XX \& Outros Textos Críticos. Natália Battella Gotilib (org.). EDUSP: São Paulo, 1993.

MELO E CASTRO, Ernesto de. Bravo, Rodrigo; Pietroforte, Antônio Vicente Seraphim. Ernesto na Torre de Babel. Anablume: São Paulo: 2016.

MENDES, Lauro Belchior; OLIVEIRA, Luiz Cláudio Vieira de (Org.). A Astúcia das Palavras: ensaios sobre Guimarães Rosa. Editora UFMG: Belo Horizonte, 1998.

MORAES, Felipe Augusto de Moraes. A arte-soma de José Agrippino de Paula. 2011. 164f. Dissertação (Mestrado em Comunicação) - Universidade de São Paulo.

MORIN, Edgar. Cultura de massas no século XX: neurose. Tradução de Maura Ribeiro Sardinha. $9^{\mathrm{a}}$ ed. Forense Universitária: Rio de Janeiro, 1997.

MORIN, Edgar. Entrevista con el filósofo Edgar Morin. La victoria fugaz de un marxismo superficial. Clarín, Revista Ñ, Buenos Aires, 04/05/2018. Disponível 
em < https://www.clarin.com/revista-enie/ideas/victoria-fugaz-marxismosuperficial O B1fFFUqpM.html > Acesso em: 03.09.2019

ORTEGA Y GASSET. A Desumanização da Arte. São Paulo: Cortez, $3^{a}$.ed., 2001.

PAZ, Octavio. Os Filhos do Barro. São Paulo: Cosac Naify, 2013.

PAZ, Octavio. O Arco e A Lira. São Paulo: Cosac Naify, 2012.

Partido Comunista Brasileiro (PCB). O PCB e o Golpe de 1964, 2014. São

Paulo: PCB, 2014. Disponível em: https://pcb.org.br/portal2/6063/o-pcb-e-ogolpe-de-1964 / Acesso em 28.07.2020

PELLEGRINI, Tânia. Relíquias da casa velha: literatura e ditadura militar, 50 anos depois. Estudos de Literatura Brasileira Contemporânea. Brasília, n.43, Jan-Jun, p.151-78, 2014. Disponível em: < http://www.scielo.br/scielo.php?script=sci abstract\&pid=S231640182014000100009\&lng=pt\&nrm=iso\&tIng=en > Acesso: em 10 mai. 2018.

PERLOFF, Marjorie. Unoriginal Genius: poetry by other means in the new century. University of Chicago Press: Londres, 2010.

PIETROFORTE, Antônio Vicente Seraphim. Semiótica Visual: os percursos do olhar. Contexto: São Paulo, 2004.

PIETROFORTE, Antônio Vicente Seraphim. Análise do texto visual: a construção da imagem. São Paulo: Contexto, 2007.

PIETROFORTE, Antônio Vicente Seraphim. A Significação da Pintura. São Paulo: Anablume, 2016.

PUBLIFOLHA. Primeira Página Folha de S. Paulo. Publifolha: São Paulo, 2000.

PEREIRA, Pedro Paulo Gomes. Sertão e Narração: Guimarães Rosa, Glauber Rocha e seus desenredos. Sociedade e Estado. Brasília, v.23, n.1, p.51-58, jan./abr.2008.

RAFAEL, Raisa Damascena. Riverão Sussuarana: uma re-visão. Departamento de Memória Social - Universidade Federal do Estado do Rio de Janeiro - UNIRIO. Manoel Ricardo de Lima Neto (Orientador). Dissertação de Mestrado, defendida em 2016. 103 fls.

RASTIER, François. Sistemática das isotopias. GREIMAS, A. J. (org.). Ensaios de semiótica poética. Cultrix, EDUSP: São Paulo, 1975.

REIMÃO, Sandra. Mercado editoral brasileiro. São Paulo: ECA-USP, 2018. Acesso em 01.01.2020. Disponível em: < http://www.livrosabertos.sibi.usp.br/portaldelivrosUSP/catalog/book/264 > 
REIMÃO, Sandra. Proíbo a publicação e circulação... - censura a livros na ditadura militar. Estudos Avançados, São Paulo, v.28, n.80, Jan./Apr. 2014. Disponível em: < https://www.scielo.br/scielo.php?script=sci arttext\&pid=S010340142014000100008 Acesso em 01.01.2020.

RIDENTI, Marcelo. Em busca do povo brasileiro: artistas da revolução, do CPC à Era da TV. São Paulo: Unesp, 2a . ed, 2014.

ROCHA, Glauber. Entrevista: Contar os donos oficiais da cultura. Acervo Folha, São Paulo, 30.mai.1978. Ilustrada, p. 37. Disponível em < https://acervo.folha.com.br/leitor.do?numero=6596\&keyword=Glauber\%2CRoch a\&anchor $=4318547 \&$ origem $=$ busca\&pd=f9ce499930276db1c6851ac352d07bc1 $>$ Acesso em: 05.11.2020.

ROCHA, Glauber. Eztetyka da Fome / Eztetyka do Sonho. Hambrecine.com. Disponível em: < https://hambrecine.com/2013/09/15/eztetyka-do-sonho/ > Acesso em: 04 dez.19

ROCHA, Glauber. Riverão Sussuarana. UFSC: Florianópolis, 2012.

SANT'ANNA Sérgio. Um Crime Delicado. Cia. das Letras: São Paulo: 1997.

SAUSSURRE, Fernand de. Curso de Linguística Geral. São Paulo: Cultrix, 2006.

SCHWARZ, Roberto. Martinah versus Lucrécia. São Paulo: Companhia das Letras, 2012.

SCHWARZ, Roberto. Cultura e política, 1964-1969. O Pai de Família e outros estudos. São Paulo: Companhia das Letras, 2008, p.70-111.

SOUZA, Jessé. A Elite do Atraso. Rio de Janeiro: Leya, 2017.

TABAROVSKY, Damián. Literatura de Esquerda. Belo Horizonte: Relicário Edições, 2017.

TATIT, Luiz. Semiótica à luz de Guimarães Rosa. São Paulo: Ateliê Editorial, 2010.

TELES, Gilberto Mendonça. Vanguarda Europeia e Modernismo Brasileiro. São Paulo: Vozes, 1977.

VELOSO, Caetano. Verdade Tropical. São Paulo: Companhia de Bolso, 2008

WARHOL, Andy; HACKETT, Pat. Popismo: os anos sessenta segundo Warhol. Rio de Janeiro: Cobogó, 2013.

XAVIER, Henrique. A Evolução da Poesia Visual: Da Grécia Antiga aos Infopoemas. Significação, Revista de Cultura Audiovisual, v. 29, n.17, São Paulo, 2002.

Disponível em: 
http://www.revistas.usp.br/significacao/article/view/65551> Acesso em: 13 abr. 2018

XAVIER, Ismail. A invenção do estilo em Glauber Rocha e seu legado para o cinema político. SCHULZE, Peter W. (edt); Shumann, Peter B. Glauber Rocha e as culturas na América Latina. TFM: Frankfurt am Main, 2011. Disponível em: < https://publications.iai.spk-berlin.de/receive/reposis-iai mods $00002243>$ Acesso em: 04.04.2020.

XAVIER, Ismail. Alegorias do subdesenvolvimento: Cinema Novo, Tropicalismo, Cinema Marginal. Brasiliense: São Paulo, 1993.

\section{NOTÍCIAS}

AUDIÊNCIA Pública na Comissão de Serviços de Infraestrutura para debater o andamento das obras do Programa de Aceleração do Crescimento - PAC, em 7 de maio de 2008. O trecho do depoimento pode ser conferido no YouTube em < https://www.youtube.com/watch?v=Tiyezo1fLRs > Acesso em 05.11.2019

COLOMBO, Sylvia. Em plebiscito histórico, chilenos decidem acabar com Constituição de Pinochet. Folha de S. Paulo, São Paulo, 25 out. 2020. Caderno Mundo, online. Acesso em 25 out. 2020. Disponível em: < https://www1.folha.uol.com.br/mundo/2020/10/pinera-vota-em-plebiscito-nochile-sobre-mudanca-na-constituicao.shtml >

Ministro da Educação defende Enem sem questões sobre ditadura. Agência Estado/ Reprodução: R7, São Paulo, 18 jan 2020. Disponível em: < https://noticias.r7.com/educacao/ministro-da-educacao-defende-enem-semquestoes-sobre-ditadura-18012020 / https://noticias.r7.com/educacao/ministroda-educacao-defende-enem-sem-questoes-sobre-ditadura-18012020 > Acesso em: 02 fev 2020.

MAGALHÃES, Guilherme. Dois terços da população dizem nunca ter ouvido falar do Al-5. Folha de São Paulo, São Paulo, 01 jan. 2020. Caderno Poder, online. Disponível em: < https://www1.folha.uol.com.br/poder/2020/01/dois-tercos-dapopulacao-dizem-nunca-ter-ouvido-falar-do-ai-5-apontadatafolha.shtml?origin=facebook\# = > Acesso em 01 jan. 2020.

O QUE Eduardo Bolsonaro realmente falou sobre o AI-5? Canal Leda Nagle. Canal do YouTube, 31 out. 2019, 53min. Acesso em 11 out. 2019. Disponível em: < https://www. youtube.com/watch?v=m cyKtITpL4 >

LISTA DOS mais vendidos de ficção de 2020. Publishnews, online. Acesso em 20 mai. 2018.2 Disponivel em: < 
https://www.publishnews.com.br/ranking/anual/9/2020/0/0 > Acesso em: 13 jun. 2018

VALENTE, Rubens. Chefe da CIA disse que Geisel assumiu controle sobre execuções sumárias na Ditadura. Folha de S. Paulo, São Paulo, 10 mai. 2018. Disponivel em: < https://www1.folha.uol.com.br/poder/2018/05/chefe-da-ciadisse-que-geisel-assumiu-controle-sobre-execucoes-sumarias-naditadura.shtml > Acesso em 20 mai. 2018.

CORONEL Paulo Malhães temia por sua vida. Carta Capital, São Paulo, 25 abr. 2014. Disponível em: < https://www.cartacapital.com.br/sociedade/coronelpaulo-malhaes-temia-por-sua-vida-9839.html >. Acesso em 25 abr. 2018.

MORRE o escritor e cineasta José Agrippino de Paula. São Paulo, O Estado de S. Paulo, 6 jul. 2007, Suplemento Cultural. Disponível em: < http://cultura.estadao.com.br/noticias/geral,morre-o-escritor-e-cineasta-joseagrippino-de-paula,16199 >. Acesso em 10 fev. de 2018.

MAISONNAVE, Fabiano. Por US\$ 0,01, porta-aviões enviado ao brasil para apoiar golpe vira sucata. Folha de São Paulo, São Paulo, 07.01.2014. Disponível em: < http://www1.folha.uol.com.br/poder/2014/01/1394142-por-us001-porta-avioes-enviado-ao-brasil-para-apoiar-golpe-de-64-vira-sucata.shtml > . Acesso em 20 mai 2018.

BOLSONARO exalta Ustra na votação do impeachment em 2016. Estadão, São Paulo, 08.08.2019, 48 seg. Disponível em: < https://www.youtube.com/watch?v=xiAZn7bUC8A\&app=desktop > Acesso em: $01 \mathrm{dez} 2020$

\section{DOCUMENTÁRIOS E CURTAS-METRAGENS}

\section{AGRIPPINO DE PAULA}

HITLER $3^{\circ}$ Mundo - PanAméricas de Áfricas utópicas. Direção: José Agrippino de Paulo. Sonda, 1968. 35mm, BP, 90min. Disponível em: < https://www.youtube.com/watch?v=HAVNYu5diNM\&feature=youtu.be $>$ Acesso em: 01 dez 2020

CANDOMBLÉ no Dahomey. Direção: José Agrippino de Paulo. 1974. Super-8, COR, 22min. Disponível em: < https://www.youtube.com/watch?v=2F6ugtqxTk\&feature=youtu.be $>$ Acesso em: $01 \mathrm{dez} 2020$ 
SINFONIA PanAmérica. Direção de Lucila Meirelles. São Paulo, 1988. Vídeo. UMatic, 15 min. Disponível em: < http://vimeo.com/51527727 >. Acesso em: 10 jun. 2014.

OS PASSEIOS no Recanto Silvestre. Produção de Reinaldo Pinheiro. Direção de Miriam Chnaiderman. São Paulo, 2006. $35 \mathrm{~mm}, 15 \mathrm{~min}$. color. son. Disponível em: < http://curtadoc.tv/curta/artes/passeios-no-recanto-silvestre/ >. Acesso em: 13 mai. 2018.

EXÚ 7 Encruzilhadas. Selo SESC: São Paulo, 2011. DVD/CD. DVDSS0011/11, 64 min. CDSS 0028/11, 58 min. color. son.

\section{DITADURA MILITAR E AUTORITARISMO}

CIDADÃO Boilesen. Direção de Chaim Litewski. Palmares Produção e Jornalismo: Rio de Janeiro, 2009. Betacam Digital, color e pb, 93min. Disponível em: < https://youtu.be/yGxIA90xXeY > Acesso em 01 dez 2020

UMA NOITE em 67. Direção de Renato Terra e Ricardo Calil. VideoFilmes Produções Artística Ltda.; Record Entretenimento: Rio de Janeiro, 2010, Dolby SRD, color e pb, 93min

O DIA que durou 21 anos. Direção de Camilo Tavares. Pequi Filmes: São Paulo, 2012, color e pb, $77 \mathrm{~min}$. Disponível em: < https://youtu.be/ltawl64zBEo > Acesso em 01 dez 2020

FINS DA democracia. SESC Pompéia: São Paulo: nov. 2017. Disponível em: < https://www.youtube.com/watch?v=PodDeQRHc2U/ >. Acesso em: 15 mai. 2018

\section{GLAUBER ROCHA}

BARRAVENTO. Direção: Glauber Rocha. Mapa Produções Cinematográficas Ltda, 1961. 35mm, BP, 80min45seg, 2.195m, 24q. Disponível em: <

https://www.youtube.com/watch?v=MoV3gsdxVfE\&feature=youtu.be $>$ Acesso em: 01 dez. 2020

DEUS o diabo na terra do Sol. Direção: Glauber Rocha. Mapa Produções Cinematográficas Ltda, 1961. 35mm, BP, $80 \mathrm{~min} 45 \mathrm{seg}, 2.195 \mathrm{~m}, 24 \mathrm{q}$. Disponível em: < https://www.youtube.com/watch?v=MoV3gsdxVfE\&feature=youtu.be > Acesso em: 01 dez. 2020 
TERRA em Transe. Direção: Glauber Rocha. Mapa Produções Cinematográficas Ltda, 1967. 35mm; P\&B; 107min. Disponível em: < https://www.youtube.com/watch?v=zYQecb9C0g4\&feature=youtu.be $>$ Acesso em: 01 dez. 2020

O DRAGÃO da Maldade contra o Santo Guerreiro" (1969). Direção: Glauber Rocha. Mapa Produções Cinematográficas Ltda, 1969. 35mm; COR; 96 min. Disponível em:

https://www.youtube.com/watch?v=SSEnlffMB5s\&feature=youtu.be $>$ Acesso em: 01 dez. 2020

DI CAVALCANTI, Di Glauber, ou Ninguém Assistiu ao Formidável Enterro de Sua Última Quimera; Somente a Ingratidão, Essa Pantera, Foi Sua Companheira Inseparável(1977). Direção: Glauber Rocha. Embrafilme S.A.; Ministério da Educação e Cultura - Departamento do Filme Cultural. 35mm, COR, 17min, 466m, 24q. Disponível em: < https://www.youtube.com/watch?v=SSEnlffMB5s\&feature=youtu.be $>$ Acesso em: 01 dez. 2020

A IDADE da Terra (1980). Direção: Glauber Rocha. Glauber Rocha Produções Artísticas Ltda.; Embrafilme - Empresa Brasileira de Filmes S.A.; Centro de Produção e Comunicação; Filmes 3, 1980. 35mm, COR, 134min, 3.667m, 24q, Eastmancolor, Scope. Disponível em: < https://www.youtube.com/watch?v=WAmJR3Km A\&feature=youtu.be > Acesso em: 01 dez. 2020

GLAUBER, o filme - Labirinto do Brasil. Direção: Silvio Tendler. Caliban, 2003. COR, 98min. Disponível em: < https://youtu.be/O1m0YQFrt5g > Acesso em 01 dez 2020 